\title{
Plate en Politiek
}

\section{POPULÉRE AFRIKAANSE MUSIEK EN DIE SAMELEWING}

\author{
$1900-2017$
}

5.D. VAN DER MERWE

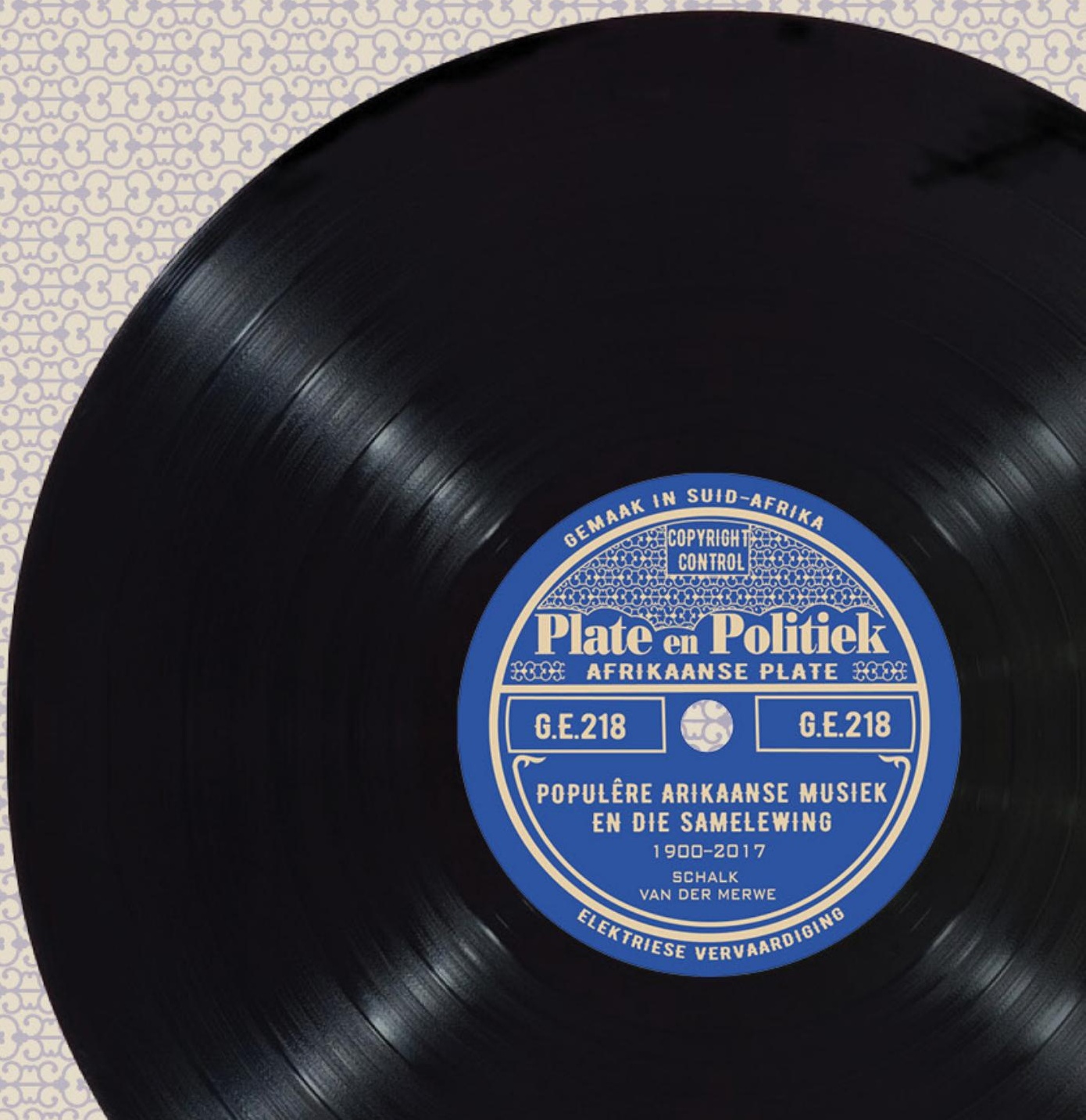




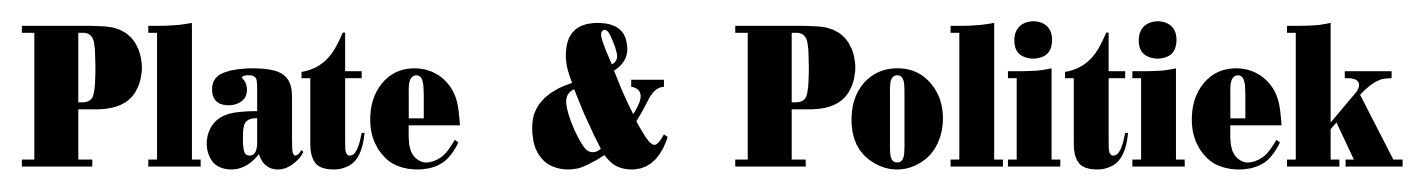

\section{POPULÊRE AFRIKAANSE MUSIEK \\ EN DIE SAMELEWING}

1900-2017

S.D. VAN DER MERWE

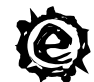

SUN PRESS 
Plate en Politiek - Populêre Afrikaanse Musiek en die Samelewing, 1900-2017

Uitgegee deur AFRICAN SUN MeDIA onder die druknaam SUN PReSS

Alle regte voorbehou

Kopiereg (C) 2019 AFRICAN SUN MeDIA en die outeur.

Hierdie publikasie is deur die uitgewer aan 'n onafhanklike dubbel-blinde portuurevaluering onderwerp.

Die outeur en die uitgewer het alles moontlik gedoen om kopieregtoestemming te verkry vir die gebruik van derdepartyinhoud en om sodanige gebruik te erken. Rig alle navrae aan die uitgewer.

Geen gedeelte van hierdie boek mag sonder die skriftelike verlof van die uitgewer gereproduseer of in enige vorm deur enige elektroniese, fotografiese of meganiese middel weergegee word nie, hetsy deur fotokopiëring, plaat-, band- of laserskyfopname, mikroverfilming, via die Internet of e-pos of enige ander stelsel van inligtingsbewaring of -ontsluiting.

Menings in hierdie publikasie weerspieël nie noodwendig dié van die uitgewer nie.

Eerste uitgawe 2019

ISBN 978-1-928357-68-1

ISBN 978-1-928357-69-8 (e-boek)

https://doi.org/10.18830/9781928357698

Geset in Minion Pro 10/13 pt

Bandontwerp en bladuitleg en produksie deur AFRICAN SUN MeDIA

SUN PReSS is 'n gelisensieerde druknaam van AFRICAN SUN MeDIA. Vakkundige, professionele en navorsingswerke word onder hierdie druknaam in druk- en elektronieseformaat uitgegee.

Hierdie publikasie kan direk bestel word by:

www.sun-e-shop.co.za

africansunmedia.snapplify.com (e-boeke)

www.sotre.it.si (e-boeke)

www.africansunmedia.co.za 
Erkennings

i

Inleiding

1

Grammofone, "warm patriotte" en radio-oorloë

19

2 "Plaaslike geur", spanning, en die opkoms van Afrikanernasionalisme

41

3 WO II, die SAUK, FAK en Boeremusiek?

63

4. Die apartheid regime, rock' $n$ roll en die Afrikanerjeug

83

5 Nuwe stemme, veranderende politiek en toenemende ondermyning

101

6 Alternatiewe Afrikaanse musiek teen die einde van apartheid

123

7 Nostalgie, vrees en wins in post-apartheid Afrikaanse musiek

139

Slot

161

Bibliografie

171

Indeks

185 


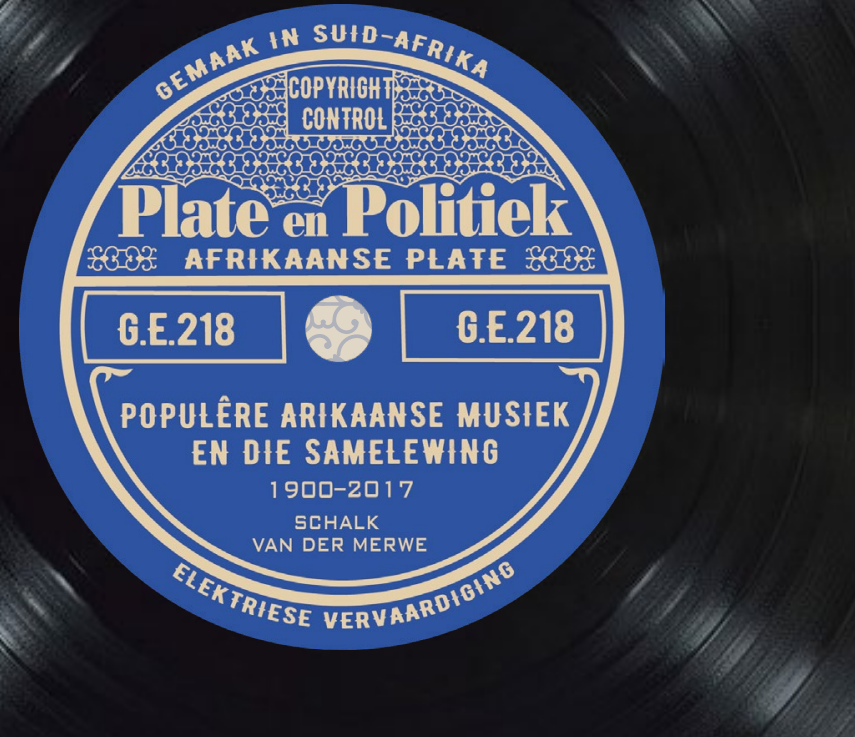




\section{ERKENNINGS}

Hierdie boek verteenwoordig die samekoms van die twee wêrelde waarin ek gelyktydig woon: die akademie en musiek. Ek is die dank verskuldig aan 'n aantal individue in beide. By Universiteit Stellenbosch: dankie aan veral Prof Albert Grundlingh vir intellektuele en logistiese ondersteuning; Prof Eugene Cloete, Vise- Rektor (Navorings, Innovering en Nagraadse Studies), vir sy ruim finansiële bydrae, en aan Prof Stephanus Muller van die Africa Open Institute, wat bydrae van onskatbare waarde gedurende die navorsingsfase gemaak het. 'n Spesiale woord van dank ook aan John Cowlin vir sy finansiële bydrae. Dankie aan die biblioteekstaf by Universiteit Stellenbosch se Biblioteekargief, die Universiteit van die Vrystaat se Insituut vir Eietydse Geskiedenis Argief, en die SABC Inligtingsbiblioteek, sowel as Justa Niemand, Emily Vosloo en Anina Joubert by African Sun Media, en aan Erna Compion vir die proeflees van 'n vroeër weergawe van hierdie teks. Op die musiekfront is daar ook'n paar mense wat, deur te doen wat hulle doen, enorm baie bygedra het tot hierdie boek. Ek is veral dank verskuldig aan Tertius Louw, 'n onvervangbare bron (wat altyd beskikbaar was) van inligting oor die geskiedenies van populêre Suid-Afrikaanse musiek. Hierdie boek is grotendeels geskryf tussen toere met my musiekkollegas Karen Zoid, Tim Rankin, Henry Steel, Kyle Petersen, Darren Petersen en Jeandré Schultz. Dankie! Ek is ook dankbaar vir my ander broers en susters in musiek: Mike en Dave, Gerald, Valiant, die ander Schalk, Vernon, Carien, Simon, Parri, Guy, Albert, Melissa, Tony G, Piet, Mel, Pietman, die ontslape Ollie Viljoen, die oorlewende lede van Die Gereformeerde Blues Band, en nog baie meer. Op 'n meer persoonlike noot, aan die twee mense aan wie hierdie boek opgedra is, julle ondersteuning en liefde bly die belangrikste. 
Aan Ilse en Valki 


\section{HNLEIDING}

\section{Kent gij dat volk vol heldenmoed en toch zo lank geknecht?'}

Die bogenoemde is die welbekende eerste strofe van die volkslied van die eertydse Transvaalse Republiek. Die bedoeling met die aanhaling daarvan is nie om 'n aanprysing te wees van wat ander beskou as "een van die beste volksliedere van alle tye" 2 of om 'n hagiografiese toon aan die Afrikanergeskiedenis ${ }^{3}$ te gee nie. Dit is eerder'n blote aanhaling van die eerste twee reëls van die eerste opname ooit van 'n stuk musiek met Afrikanerwortels. ${ }^{4}$ In Januarie 1900 het drie Europese sangers, nie besonder beroemd nie, elk 'n opname van die lied gemaak - J.C. van den Berg in Den Haag, en Ewald Brückner en H. Cornelli in Berlyn. Op dieselfde dag waarop Van den Berg in die ateljee in Den Haag was, het E. Spieksma ook opgedaag om twee ander liedjies met 'n

1 Vert. "Ken jy die volk vol heldemoed en tog so lank gekneg?"

2 A. M. Swanepoel, "Music inspired by the Afrikaner cause (1852-1902), with special reference to the Transvaal Volkslied”, ongepubliseerde M. Tesis (Universiteit van Suid-Afrika, 1979).

3 Dit het gebruiklik geraak om die term "Afrikaner" te kwalifiseer. Dit word hier gebruik as 'n beskrywing van iemand wat wit is en Afrikaans praat. Alle wit Afrikaanssprekers self-identifiseer beslis nie as "Afrikaners" nie, maar voorkeur word gegee aan "Afrikaner" en nie "wit Afrikaanssprekers" nie, want die eersgenoemde het historiese strekking en het gedien as 'n kern waar rondom sulke konsepte soos "Afrikanernasionalisme" ontstaan het. Dit dui ook op rasse-eksklusiwiteit en 'n rasse-hierargie wat aan die spil is van Afrikaanse taalpolitiek en het direkte betrekking op die inhoud van hierdie boek. Dit is ook belangrik om uit te wys dat wit Afrikaanssprekers, ten spyte daarvan dat hulle histories kuratorskap oor die taal geëis het, 'n minderheid (omtrent 40\%) van alle eerste-taal Afrikaanssprekers beslaan.

4 Ian Colquhoun het "We are marching to Pretoria" in 1899 opgeneem, wat sover as wat vasgestel kan word, die vroegste verwysing na Suid-Afrika in opgeneemde musiek is. In hierdie geval lê die wortels natuurlik by die Britte. 
boere-oorsprong op te neem - "Transvaal en Nederland" en "Volkslied van den Oranje Vrijstaat", die volkslied van die ander Boererepubliek, die Oranje Vrystaat. Dit was die eerste twee Africana-grammofoonopnames, meer Hollands as Afrikaans, maar tog 'n onbedoelde begin vir die Afrikaanse musiekbedryf. Hoekom het hulle die liedere opgeneem? Het hulle daarmee een of ander vorm van solidariteit of waardering vir die Boere uitgespreek wat teen die Britte geveg het op die slagvelde van die Anglo-Boereoorlog? Dit is welbekend dat die twee Boererepublieke minstens die morele ondersteuning van baie Europeërs gehad het tydens die oorlog. Meer as 100 jaar later, in Oktober 2006, is die debuut-album wat die vinnigste nog verkoop het in die geskiedenis van Afrikaanse musiek uitgereik. ${ }^{5}$ Die gewildheid daarvan was weens'n trefferliedjie vernoem na 'n Boeregeneraal uit daardie selfde oorlog en wat merkwaardig ooreenstem met die sentiment van Van den Berg, Brückner, Cornelli en Spieksma. Die liedjie was "De la Rey" deur die sanger Bok van Blerk. Daar het natuurlik baie gebeur tussen 1900 en 2006 . Enigiemand wat selfs net 'n bietjie kennis dra van Suid-Afrikaanse geskiedenis in die twintigste eeu sal weet van die rassistiese beleid van apartheid, die afskaffing daarvan en die gevolglike oorgang na 'n demokratiese bestel in 1994. Dit is daarom 'n merkwaardige kenmerk van die Afrikanergemeenskap in 'n post-apartheidkonteks dat die oproeping van - nie noodwendig letterlike nie, maar wel metaforiese - "volk vol heldenmoed en toch zo lang geknecht" so diep met die gemeenskap sou resoneer. Of dalk nie. Volk dui op Afrikanernasieskap en hegemonie - 'n gelaaide en onafgestorwe kenmerk van Suid-Afrikaanse geskiedenis.

Die band tussen musiek en nasieskap is niks nuuts nie en was reeds in Antieke Griekeland 'n besprekingspunt. In Plato se Die Republiek IV eggo Sokrates in sy gesprek met Adeimantus, Damon se standpunt dat "wanneer die modes van musiek verander, verander die fundamentele wette van die Staat daarmee saam". ${ }^{6}$ Of dit 'n effense oordrywing is of nie - hy het per slot van rekening ook tot min of meer dieselfde gevolgtrekking gekom oor gimnastiek - of 'n growwe oorvereenvoudiging, was daar wel al 'n hele aantal historiese periodes waartydens sosiale verandering geresoneer het met die musiek van die dag. Die sosiale bewegings van die 1960's en hul bande met populêre musiek (soos Bob Dylan) is 'n goeie voorbeeld. As geskiedkundige en musikant is ek al lank geïnteresseerd in dié verband.

As 'n eerstejaarstudent aan die Universiteit Stellenbosch in 1995, het ek by 'n eksperimentele prog rock-groep die Wild Possums aangesluit en my eerste optrede saam met hulle was om te open vir die legendariese Voëlvry ${ }^{7}$ - rocker/digter Koos Kombuis. Al het ons 'n allemintige klomp drank op sy rekening bestel (ons moes ons naam gestand doen) en nogal vrot gespeel, het hy ons op die verhoog genooi om sy liedjie "Katie" saam met hom te speel. Dit was dalk nie 'n hoogtepunt in die geskiedenis van Suid-Afrikaanse musiekoptredes nie, maar dit was 'n betekenisvolle oomblik vir my. Wat ek nie besef het nie, is dat ek heeltemal per ongeluk ingestap het in 'n besonder lewendige Stellenbosse musiektoneel (vir 'n ruk lank het

5 Die album het aanvanklik 'n paar onsuksesvolle maande op die rak gestaan voordat dit van noemenswaardige belang geraak het.

6 Hierdie weergawe blyk die mees gewilde te wees en word in 'n verskeidenheid materiaal aangehaal, van moederskaps-blogs tot webtuistes oor musiekopvoeding en selfs Christelike pamflette. Vir enigiemand wat in ander vertalings geïnteresseerd is, die aanhaling kom uit 424 V.c. in Plato se The Republic, Book IV.

7 Voëlvry was 'n rebelse en anti-regime Afrikaanse rock-beweging/musiektoer in 1989 wat rondom kunstenaars Johannes Kerkorrel, James Phillips (as sy Afrikaanse verhoogpersona, Bernoldus Niemand) en André Letoit (later Koos Kombuis) gedraai het. 
radio-platejoggies dit grappenderwys "Stellenattle" genoem na die grunge-ontploffing in Seattle in die vroeë 1990's) wat floreer het in die nuut-demokratiese Suid-Afrika. Aan die voorpunt was die plaaslike rockers Springbok Nude Girls (al vyf lede is Afrikaans maar die liedjies was Engels) en die sanger/liedjieskrywer Valiant Swart wat vinnig 'n nasionale gevolg opgebou het met sy Afrikaanse blues rock, of soos hy dit genoem het, "Boland Punk". "Dagga" Dirk Uys, organiseerder en toerbestuurder vir die Voëlvry-toer, het Trippy Grape-platemaatskappy gestig, verskeie plaaslike groepe bestuur en die jaarlikse Wingerdrock-musiekfees (1995-1998 en weer in 2003) georganiseer. Al het die Wild Possums nie lank gehou nie, was ek gelukkig genoeg om nederige werkies te kry by ander groepe op die toneel en ek het saam met 'n mengelmoes van Engelse en Afrikaanse solo-kunstenaars gewerk oor die volgende 20 jaar. Ek kan nie met sekerheid sê in hoeveel shows ek gespeel het of hoeveel albums, feeste en toere daar was nie. Nodeloos om te sê dit het my besig genoeg gehou.

Hierdie boek is wel nie 'n biografie van die kunstenaars saam met wie ek gewerk het of, die hemel behoede ons!, 'n outobiografie van my loopbaan as baskitaarspeler nie. Dit is ook nie oor Suid-Afrikaanse jazz, marabi, $k w e ̂ l a,{ }^{8}$ mbube, mbaqanga, maskandi, isicathamiya, hip-hop of kwaito nie. Almal van hulle is dinamiese musiekgenres wat ontwikkel is deur plaaslike swart en bruin musikante en is lank reeds gunsteling temas vir geleerdes wat belangstel in Suid-Afrikanse populêre musiek en verset. ${ }^{9}$ Die boek spruit uit my noue betrokkenheid by 'n spesifieke seksie van die Afrikaanse musiekbedryf en my waarnemings oor 'n lang tydperk van hoe die musiek vervaardig, opgevoer en geluister word deur gewone mense.

Die honderde Afrikaanse konserte en kunstefeeste (en ek gebruik'n breë definisie hier om feeste in te sluit wat meer "plaaslike verskeidenheid" as "kuns" is) waarby ek oor die jare heen was, het my bekendgestel aan 'n hele aantal hoofstroom-Afrikaanse popsterre wat'n goeie bestaan maak deur die land te toer, meesal met net 'n mikrofoon en backtracks (waar die kunstenaar sing met voorafopgeneemde musiek eerder as om musikante saam met hulle op die verhoog te hê) in hul arsenaal. Die entoesiastiese skares wat hulle inwag in stede en verskeie plattelandse dorpe wat groot genoeg is om sulke geleenthede aan te bied is amper almal wit en daar is gewoonlik duisende. Ek moet erken, nadat ek na hulle musiek geluister het, wonder ek soms hoekom sommige Afrikaanse kunstenaars so goed vaar terwyl die meeste van die beste (na my mening) skrywers van Afrikaanse liedjies so sukkel. Om dit doodeenvoudig te stel as iemand wat meesal op die rock-kantlyn gesit en ingekyk het, het ek gesukkel om die dinamiek van die kulturele inkoop deur soveel Afrikaners in hoofstroom-Afrikaanse musiek te verstaan. Hoewel 'n mens se eie, normatiewe oordeel geensins 'n geldige epistemologiese vertrekpunt is vir wat veronderstel is om 'n objektiewe werk te wees nie, is dit steeds een van my primêre motiverings vir die boek.

8 Dit raak wel aan kwêla se invloed op Afrikaanse musiek.

9 Sien byvoorbeeld V. Erlmann, Nightsong: performance, power, and practice in South Africa (Chicago: University of Chicago Press, 1996) oor isicathamiya en African stars: studies in black South African performance (Chicago: University of Chicago Press, 1991) oor vroeë ragtime, ingoma, en isicathamiya; C. Devroop and C. Walton (reds.), Unsung: South African jazz musicians under Apartheid (Stellenbosch: SUN PReSS, 2007) oor jazz, en ook G. Ansell, Soweto blues : jazz, polular music, and politics in South Africa (New York, Continuum, 2004) wat ook kyk na ander populêre musiekstyle; D. Coplan, In township tonight! South Africa's black city music and theatre (Johannesburg: Ravan Press, 1985) oor swart uitvoerende kunste en L. Meintjies, Sounds of Africa!: Making music Zulu in a South African studio (Durham: Duke University Press, 2003) oor die ateljeeproduksie van 'n mbaqanga-album; en ook C.A. Muller, Focus: music of South Africa (New York: Routledge, 2008) oor populêre musiek in Suid-Afrika gedurende die twintigste eeu. 
Dit was gelukkig lonend, want die sosiale dinamika van hoofstroom-Afrikaanse musiek, veral in die aanloop tot die einde van apartheid en daarna, verteenwoordig 'n samevloeiing van breër maatskaplike kwessies en spanning wat nadere ondersoek verdien.

Verder bied hierdie verhoudinge'n alternatiewe blik op die lewens van Afrikaanssprekers weg van die sleutel-politieke en ekonomiese gebeurtenisse en elite individue, en getuig van die agentskap van kunstenaars en 'gewone' mense. Om die interaksie tussen hierdie 'normale mense' en dinamiese, eksterne mag- en invloedstrukture te oorweeg is fundamenteel om die ontwikkeling van Afrikaanse kultuur deur die twintigste eeu te verstaan. Dit is ook 'n noodsaaklike oefening wanneer taal- en kulturele identiteite vandag oorweeg word.

Die primêre fokus hier is op opgeneemde Afrikaanse musiek, aangesien opnames 'n baie bruikbare bron is wat optree as artefakte wat - tot verskillende mates - die verhouding tussen die individue wat die opnames vervaardig en/of luister en die gemeenskappe waarmee hulle hulleself assosieer, reflekteer. In kort: daar is 'n verband tussen die musiek waarna mense luister (en wat hulle koop) en die gemeenskap (of spesifieke deel van 'n gemeenskap) waarin hulle leef. En, musiekopnames wat op die radio en TV (albei mediums waarin daar histories kwaai gewedywer is in die Suid-Afrikaanse konteks) gehoor kan word en honderde duisende luisteraars kan bereik, het histories op 'n veel groter skaal gefunksioneer en onder ander omstandighede as onopgeneemde musiek. Die verhaal van populêre Afrikaanse musiek is ingewikkeld, grootliks weens die sosio-politieke konteks van die ontwikkeling daarvan. Navorsing oor die kosbare versameling van Afrikaanse kulturele skatte opgesluit in die onopgeneemde musiek van die platteland en in die geskiedenis van die Kaap in besonder sal beslis meer fokus op die musiek van die bruin en swart Afrikaanssprekendes. Daarin lê een van die sentrale fokuspunte van hierdie boek - die manier waarop opgeneemde populêre Afrikaanse musiek die breër verhaal van die skeiding van rasse en wit dominasie in Suid-Afrika gereflekteer en aanvaar het. Tot 'n groot mate het kommersiële Afrikaanse musiek gefunksioneer as artefakte wat die geskiedenis van wit gemak uitbeeld.

\section{'n Gefragmenteerde historiografie}

'n Vinnige kykie na die literatuur wys 'n verrassende gebrek aan omvattende studies wat 'n wye historiese tydperk dek. Een verkorte weergawe is die Gallo Record-platemaatskappy se argivaris Rob Allingham se insiggewende opsomming van die geskiedenis van populêre Afrikaanse musiek in sy bydrae tot die Afrika, Midde-Oosterse en Europese seksie van World Music: The Rough Guide. ${ }^{10}$ Op een bladsy lig hy talle van die belangrikste historiese temas in die ontwikkeling van populêre Afrikaanse musiek in die twintigste eeu uit. Dit sluit in die invloed van ingevoerde Amerikaanse musiek op die "konsertina-geleide tipe dansmusiek" van die 1930's (en later country-musiek), die agtergrond van Afrikanernasionalisme, die ná-oorlogse na-aping van ligte Europese middewegmusiek-style, die opkoms van alternatiewe Afrikaanse musiek in die 1980's en 1990's, en die verband tussen diegene wat musiek laat herleef het en die regse politiek ná 1994. Dit is 'n prysenswaardige prestasie. As dit tien jaar later gepubliseer is, sou dit sonder twyfel die suksesverhaal van Afrikaanse popmusiek ná 2000 en die impak van "De la Rey" ingesluit het. 'n Ander voorbeeld is die dokumentêre reeks Kom laat ons sing,

10 S. Broughton, M. Ellingham en R. Trillo (reds.), World Music: The Rough Guide. Africa, Europe and the Middle East, South Africa - Popular Music: Nation of Voice Vol. 1 (Londen: Rough Guides, 1999), p. 651. 
aangebied en mede-vervaardig deur die sanger Laurika Rauch. ${ }^{11}$ Die hooffokus daarvan was Musiek-en-Liriek (met verwysing na 'n TV-program wat in 1979 uitgesaai is en die musiekfase wat daaruit voortgevloei het), maar dit het ook 'n wyer historiese perspektief op populêre Afrikaanse musiek van die 1930's tot 1990's gebied. 'n Hele aantal van die kunstenaars met wie onderhoude vir die dokumentêr gevoer is, het verwys na die spanning tussen die meer "ernstige" kunstenaars en hoofstroom-pop, veral wanneer dit kom by die vertaling van Europese treffers in Afrikaans, wat laasgenoemde se gebruik was (en vandag steeds is). Daar was ook die hardnekkige opvatting dat 'n mens nie goeie musiek in Afrikaans kan maak nie en dat dit begin verander het met Musiek-en-Liriek, terwyl daar ook'n algemene konsensus was dat apartheid en sensorskap musiekinnovasie gekeer het en dat die post-apartheidsera 'n tyd van bevryding van hierdie beperkende omstandighede was. Nie Allingham se opsomming of Kom laat ons sing het gekyk na die era voor die 1930's nie en, weens die tydstip waarop dit uitgereik is, het nie een kommentaar lewer oor die meer onlangse verwikkelinge in populêre Afrikaanse musiek nie.

Pat Hopkins se boek oor die Voëlvry-toer ${ }^{12}$ en die DVD vervaardig deur Lloyd Ross van Shifty Records wat daarmee saam uitgereik is verwys ook na die historiese verhouding tussen Afrikanernasionalisme en Afrikaanse musiek. Dit het op'n knap manier die Voëlvry-kunstenaars geplaas teen die agtergrond van 'n konserwatiewe Afrikaanse gemeenskap met diep historiese wortels wat ver wyer as die 1980's gestrek het. Koos Kombuis se Seks, drugs en boeremusiek ${ }^{13}$ en Short drive to freedom ${ }^{14}$ gee ook 'n outobiografiese weergawe van sy belewenis van Voëlvry. Slabbert en De Villiers se David Kramer, 'n Biografie is 'n gesaghebbende bron oor dié invloedryke kunstenaar. ${ }^{15}$ Daar is ook werke soos Danie Pretorius se Musieksterre van gister en vandag: Lewensketse En Foto's Van Meer as 100 Musieksterre ${ }^{16}$ en Ilza Roggeband se 50 Stemme: Die grootste name in Afrikaanse musiek ${ }^{17}$ wat interessante biografiese en diskografiese inligting oor prominente Afrikaanse sangers gee, maar hulle nie noodwendig in hulle onderskeie sosiale kontekste plaas nie. 'n Seldsame akademiese ondersoek na populêre Afrikaanse musiek is Willemien Froneman se musiekologiese werk oor boeremusiek, ${ }^{18}$ wat van spesifieke belang is vir die periode van die 1930's tot die 1950's toe dit een van die gewildste genres van opgeneemde Afrikaanse musiek was. Wilhelm Schultz se werk oor die herkoms van boeremusiek wat 'n afdeling bevat oor die vroeë geskiedenis van die musiekopnamebedryf in Suid-Afrika, is ook insiggewend. ${ }^{19}$ Ander onlangse musikologiese studies het gefokus op die historiografie van

11 Laurika Rauch, Johan Badenhorst en Annelize Bothma: “Kom laat ons sing: 'n musikale reis deur Laurika Rauch - 'n Dokumentêr" (Laurika Rauch Produksies, 2003).

12 Voëlvry: The Movement That Rocked South Africa (Kaapstad: Zebra Press, 2006).

13 Seks, drugs en boeremusiek: die memoires van ' $n$ volksverraaier (Kaapstad: Human \& Rousseau, 2000).

14 Short drive to freedom: a personal perspective on the Afrikaans rock rebellion (Kaapstad: Human \& Rousseau, 2009).

15 (Kaapstad: Tafelberg, 2011).

16 (Pretoria: JP \& Son van der Walt, 1998).

17 (Kapstad: Delta, 2009).

18 W. Froneman, "Pleasure Beyond the Call of Duty: Perspectives, Retrospectives and Speculations on Boeremusiek", ongepubliseerde D.Phil tesis, Universiteit Stellenbosch, 2012; sien ook S.H.R. Louw, "Nico Carstens as innoveerder van Suid-Afrikaanse populêre musiek", ongepubliseerde M.Mus verhandeling, Universiteit van die Vrystaat, 2013. Boeremusiek is 'n genre van musiek bekend vir sy gebruik van die konsertina.

19 W. Schultz, Die Ontstaan en Ontwikkeling van Boeremusiek (Pretoria: A.V.A. Systems, 2001). 
klassieke Afrikaanse musiek tydens en voor apartheid, ${ }^{20}$ maar nie populêre Afrikaanse musiek per se nie.

Denis-Constant Martin se Sounding the Cape is 'n belangrike werk wat 'n lang, historiese verslag gee van die sosiale kompleksiteite wat 'n rol gespeel het in die ontwikkeling van musiektradisies in die Kaap en elders. Dit skenk gedetaileerde aandag aan die enorme kulturele bydrae van bruin en swart musikante oor 'n verskeidenheid van genres heen en belig die rol wat rassegregasie gespeel het in die opbreek van musikale verhoudings wat histories sosiale grense getrasendeer het. Een van die grootste suksesse van die werk is dat dit die geïsoleerdheid wat steeds in die musiekbedryf voorkom, oorbrug om 'n omvattende en gebalanseerde blik op die musiek van die Kaap te gee. Die fokus van hierdie boek is egter nie op so 'n manier gebalanseer nie. Die doel daarmee is om die einste geïsoleerdheid van populêre Afrikaanse musiek te ondersoek en in oënskou te neem. Hierdie geïsoleerdheid is die gevolg van die geskiedenis aan die een kant, maar is ook 'n aanduiding van kontemporêre politieke en sosiale magte.

Terwyl daar'n gebrek is aan studies oor populêre Afrikaanse musiek wat dit deur'n wye historiese lens beskou, is daar'n wesenlike hoeveelheid akademiese werk oor populêre Afrikaanse musiek wat meer spesifiek gefokus is. Onlangs het die kontroversiële zef (kômmin of werkersklas) rap-groep, Die Antwoord, wye akademiese belangstelling gewek. Hoewel hulle wit is, het hulle grootliks geleen van bruin en swart bendekultuur, en die groep se toe-eiening van die kulturele gebruike van "ander" was die besprekingspunt van 'n spesiale uitgawe van die joernaal Safundi. ${ }^{21}$ Ander artikels oor Die Antwoord het gefokus op egtheid, witheid, kulturele toe-eiening en soortgelyke kwessies. ${ }^{22}$ Adam Haupt het gekyk na Bok van Blerk en Die Antwoord (spesifiek laasgenoemde se gebruik van blackface) in sy ondersoek na ras en bemiddeling in musiek, media en film sedert die einde van apartheid. ${ }^{23}$ Hulle uitbeelding van die Suid-Afrikaanse werkersklas vermeng met 'n goeie skoot bendekultuur in 'n stedelike Afrika-opset is eksoties vir 'n internasionale gehoor en integraal tot hulle sukses. Maar, behalwe vir hulle naam, gebruik hulle Afrikaans slegs sporadies en hulle pas nie werklik gemaklik onder die vaandel van Afrikaanse musiek nie, hoe vaag dit ook al mag klink. As gevolg daarvan, verskyn hulle slegs kortliks in Hoofstuk Sewe. In teenstelling het Voëlvry direkte betrekking hier en behalwe vir Hopkins se boek het Jury, ${ }^{24}$

20 Sien verhandelinge deur C. Venter, "The Influence of Early Apartheid Intellectualisation on Twentieth-Century Afrikaans Music Historiography”, ongepubliseerde M.Mus verhandeling, Universiteit Stellenbosch, 2009;

A. Stimie, "Cosmopolitanism in early Afrikaans music historiography, 1910-1948”, ongepubliseerde M.Mus verhandeling, Universiteit Stellenbosch, 2010.

21 A. Haupt, "Part IV: Is Die Antwoord Blackface?” Safundi, 13:3-4 (2012), pp. 417-423; A. Kreuger, "Part II: Zef/ Poor White Kitsch Chique: Die Antwoord's Comedy of Degradation”, Safundi, 13:3-4 (2012), pp. 399-408;

S. O’Toole, “Part I: Die Antwoord's state of exception", Safundi, 13:3-4 (2012), pp. 393-399;

L. Van der Watt, "Part III: Ask no questions, hear no lies: Staying on Die Antwoord's surface", Safundi, 13:3-4 (2012), pp. 409-416.

22 H. Marx en V.C. Milton, "Bastardised whiteness: 'zef'-culture, Die Antwoord and the reconfiguration of contemporary Afrikaans identities", Social Identities, 17:60 (2011), pp. 723-745; C. Scott, "Die Antwoord and a delegitimised South African whiteness: a potential counter-narrative?" Critical Arts, 26:5 (2012), pp. 746-761; A. Haupt, "Citizenship without representation? Blackface, misogyny and parody in Die Antwoord, Lupé Fiasco and Angel Haze", Communicatio, 39:4 (2013), pp. 466-482; S. Smit, "Enter the imperceptible: Reading Die Antwoord", Cogent Arts and Humanities, 2:1 (2015), pp. 1-9.

23 Static: Race and Representation in Post-Apartheid Music, Media and Film (Kaapstad: HSRC Press, 2012).

24 B. Jury, "Boys to Men: Afrikaans Alternative Popular Music, 1986-1990", African Languages and Cultures, 9:2 (1996), pp. 99-109. 
Grundlingh, ${ }^{25}$ Bosman, ${ }^{26}$ Viljoen, ${ }^{27}$ Laubscher ${ }^{28}$ Suriano en Lewis, ${ }^{29}$ en Baines ${ }^{30}$ ook direk op die beweging of op die kunstenaars wat betrokke was gefokus. Hierdie belangstelling spruit uit die overte politieke protes in hulle musiek - 'n ongewone ding in populêre Afrikaanse musiek voor die Voëlvry-beweging. Protessangers, digters (deur literatuurstudies van hulle lirieke) of Afrikaanse musiekbewegings domineer tipies die diskoers oor populêre Afrikaanse musiek. ${ }^{31}$ As gevolg daarvan was kunstenaars soos Koos Kombuis, Johannes Kerkorrel (en later groepe soos die Afrikaanse punk rockers Fokofpolisiekar) ${ }^{32}$ meer gereeld die fokus van akademiese werke. "De la Rey" het ook oor die laaste dekade baie akademiese aandag geniet. Die liedjie het 'n onweerstaanbare geleentheid gebied om te kyk na die verhouding tussen populêre musiek en Afrikaner-identiteit en hulle verhouding met die verlede. Die rede vir soveel aandag was die verwysing daarin na die Boere-generaal Koos de la Rey, die feit dat dit die Afrikaanse debuut- album was wat die vinnigste in die geskiedenis verkoop het en dat dit tot so 'n mate die regte snaar aangeroer het vir soveel Afrikaners. Onder al die kompleksieteite rondom die "afbreek van die ankertoue van identiteit", om Leswin Laubscher ${ }^{34}$ te parafraseer, was hier 'n liedjie wat talle Afrikaners bymekaar gebring het. Hierdie gewildheid het daartoe gelei dat party mense tot die gevolgtrekking gekom het dat dit die simbool van Afrikaner-eenheid geword het in 'n tyd waarin daar bitter min kulturele ruimte - behalwe vir sport en braai - oor was in post-apartheid Suid-Afrika wat deur noemenswaardige getalle Afrikaners ondersteun word. Dit het ook in die media en die akademie wye kommentaar uitgelok oor Afrikaner-identiteit, wat weer gelei het tot debatte oor of Afrikanernasionalisme weer aan die groei was en of hierdie 'n

25 A. Grundlingh, "Rocking the boat'? The 'Voëlvry' music movement in South Africa: Anatomy of Afrikaans anti-apartheid social protest in the eighties", The International Journal of African Historical Studies, 37:3 (2004), pp. 483-514.

26 M. Bosman, "Die FAK-Fenomeen: populêre Afrikaanse musiek en volksliedjies", Tydskrif vir Letterkunde, 41:2 (2004), pp. 21-46.

27 M. Viljoen, “Johannes Kerkorrel and post-apartheid Afrikaner identity”, Literator ,26:3 (2005), pp. 65-81.

28 L. Laubscher, "Afrikaner identity and the music of Johannes Kerkorrel”, pp. 308-330.

29 M. Suriano en C. Lewis, "Afrikaners is Plesierig! Voëlvry Music, Anti-apartheid Identities and Rockey Street Nightclubs in Yeoville (Johannesburg), 1980s-90s”, African Studies, 74:3 (2015), pp. 404-428.

30 "Popular Music and Negotiating Whiteness in Apartheid South Africa", in G. Olwage (red.), Composing Apartheid: Music for and Against Apartheid (Johannesburg: Wits University Press, 2008), p. 108. Baines het ook gekyk na die satiriese element in werk van David Kramer wat witheid ondermyn het gedurrende die 1980's.

31 B.A. Senekal en C. van den Berg, "'n Voorlopige verkenning van post-apartheid Afrikaanse protesmusiek", LitNet Akademies, 7:2 (2010), pp. 98-128.

32 A.E. Klopper, "Die opkoms van Afrikaanse rock en die Literêre status van liriek, met spesifieke verwysing na Fokofpolisiekar", MA Verhandeling, Universiteit Stellenbosch, Maart 2009; ook Biografie van 'n bende: Die storie van Fokofpolisiekar (Kaapstad: Protea, 2011).

33 Sien K. du Pisani, "Puritanism transformed: Afrikaner Masculinities in the Apartheid and Post-Apartheid Period", in R. Morrell (red.), Changing Men in Southern Africa (Durban: Zed Books, 2001), pp. 157-175; D. Pretorius, "The Visual Representations of Masculinities in Die Huisgenoot Tempo Magazine”, Cmmunicatio, 39:2 (2013), pp. 210-232; A. Bezuidenhout, "From Voëlvry to De La Rey: Popular Music, Afrikaner Nationalism and lost irony", Universiteit Stellenbosch seminar, 2007; G. Baines, "De La Rey Rides (Yet) Again: Afrikaner Identity Politics and Nostalgia in Post-Apartheid South Africa”, Referaat aangebied by die IASPM Konferensie, Liverpool, Julie 2009; D. Roodt, “The 'De la Rey' Song: Is it a sign of Afrikaner resistance?” American Renaissance, 18:10 (2007); M. Wines, “Song Wakens Injured Pride of Afrikaners”, New York Times, 17 Feb, 2007; L. Lambrechts en J. Visagie, “De la Rey, “De la Rey”, sal jy die boere kom lei?” Litnet Akademies, 6:2 (2009); C. Lotter, "The De la Rey Phenomenon - More than a Song?" Voices: A World Forum for Music Therapy, 7:2 (2007), beskikbaar by https://voices.no/index.php/voices/article/view/490/397 [besoek 10 April 2012].

34 L. Laubscher, "Afrikaner identity and the music of Johannes Kerkorrel”, South African Journal of Psychology, 35:2 (2005), p. 308. 
verklaring sonder skuldgevoel was van 'n identiteit wat ontstaan het in 'n tyd toe die Afrikaner die slagoffer was en nie die skuldige nie. ${ }^{35}$ Afgesien van regse Afrikaner-groepe wat die liedjie probeer kaap het as 'n oproep om wapens op te neem (en van wie Van Blerk hom in die openbaar distansieer het), ${ }^{36}$ was daar skynbaar skielik 'n bewustheid van 'n element van wyer kohesie in Afrikaner-gemeenskappe. Te oordeel aan populasiesyfers en as'n mens aanneem (vir geen rede anders as spekulasie nie) dat die gewildheid beperk is tot wit Afrikaanssprekendes, het min of meer een uit tien van hulle die album gekoop. Dit het selfs die New York Times ${ }^{37}$ gehaal en is kortliks bespreek in die Parlement. ${ }^{38}$

Dit is verstaanbaar dat die liedjie hierdie soort aandag geniet het, maar die gewildheid daarvan is geensins buitengewoon as dit gesien word teen die konteks van kommersiële/ hoofstroom $^{39}$ - Afrikaanse musiek nie. Verskeie kunstenaars het al albums uitgereik waarvan net soveel of selfs meer kopieë as "De la Rey" verkoop is, maar die verband tussen hulle en hoe verteenwoordigend hulle is van spesifiek wit Afrikanerskap moet nog in konteks geplaas word. In die era ná apartheid was daar 'n groot opbloei in die Afrikaanse musiekbedryf, maar daar is geen akademiese diskoers oor bevoorbeeld Theuns Jordaan se albums Vreemde Stad en Tjailatyd waarvan daar meer as 200000 elk verkoop is nie. Of van Steve Hofmeyr se Toeka (met die treffer "Pampoen" op en waarvan ook meer as 200000 verkoop is $)^{40}$ nie. Robbie Wessels het in dieselfde jaar waarin "De la Rey" uitgereik is die treffer "Leeuloop" van die album Halley se Komeet, waarvan meer as 100000 kopieë verkoop is, uitgereik. ${ }^{41}$ Juanita du Plessis se "Ska Rumba" was'n reuse-treffer, en ook Kurt Darren se "Meisie Meisie" en "Kaptein" - meer as 100000 kopieë is van elk van die albums waarop die liedjies is, verkoop. Na raming is 275000 kopieë van Leon Schuster se "Hier Kommie Bokke" in 1995 verkoop toe Suid-Afrika die Wêreldbeker-rugbytoernooi aangebied het. Dié kunstenaars verteenwoordig verskillende style - Theuns Jordaan en Bok van Blerk, byvoorbeeld, is meer Afrikaanse folk-rock, terwyl Kurt Darren doodgewone Afrikaanse dans-pop sing. "Ska Rumba" is ook 'n popliedjie, terwyl "Die Leeuloop" komies is en "Pampoen" nostalgies. "Hier Kommie Bokke" is, by gebrek aan 'n beter beskrywing, rugby-pop (en Suid-Afrika is waarskynlik een van bitter min lande waarin hierdie genre sal werk ...). Om 'n volledige en aanvaarbare spektrum van die verskillende genres wat Afrikaanse kunstenaars uitreik te verskaf sal na my mening 'n vrugtelose oefening wees. Die grense is vaag en die menings verskil te veel. ${ }^{42}$ Wat hierdie kunstenaars wel in gemeen het, is hulle geweldige gewildheid onder Afrikaanssprekendes.

35 Bezuidenhout, “From Voëlvry to De La Rey”, p. 4; sien ook K. van der Waal en S. Robins, “De la Rey” and the Revival of 'Boer Heritage': Nostalgia in the Post-apartheid Afrikaner Culture Industry”, Journal of Southern African Studies, 37:4 (2011), pp. 763-779.

36 Bezuidenhout, "From Voëlvry to De La Rey", p. 3.

37 M. Wines, New York Times, 17 Feb, 2007.

38 Ibid.

39 Daar is geen duidelike definisie vir "kommersiële" of "hoofstroom" musiek nie, en dit word hier gebruik om die topverkopende afdeling van Afrikaanse musiek te beskryf, eerder as 'n spesifieke genre. Stilisties was "hoofstroom" nog altyd divers, maar is gewoonlik gedomineer deur popmusiekstyle, eerder as byvoorbeeld Afrikaanse rock, wat gewoonlik'n kleiner gehoor het. Die dinamika van Afrikaanse musiek skryf, opneem en vrystel, spreek tot 'n wyer gehoor en word deur die smake van hierdie mark bepaal. Geskiedkundig is hierdie mark onderwerp aan verskillende sosiale kragte gedurende die twintigste en een-en-twintigste eeu, wat in volgende hoofstukke bespreek sal word.

40 I. Roggeband, 50 Stemme: Die grootste name in Afrikaanse musiek (Kaapstad: Delta, 2009), p. 241.

41 T. Ridgeway, “Is Local nog lekker?", Pomp, 2011, p. 145.

42 Vir 'n insiggewende analise oor die problematiese definisie van 'pop' en 'populêre' musiek, sien C. Rojec, Pop Music, Pop Culture (Cambridge: Polity, 2011). 
Histories gesproke is hierdie Afrikaanse kunstenaars nie die enigste met goeie verkope nie. Bles Bridges was een van die gewildste Afrikaanse sangers van die 1980's en 90's. Nico Carstens het 'n baie lang loopbaan gehad en is waarskynlik die Afrikaanse musiekkunstenaar met die meeste verkope (hoewel hy streng gesproke'n instrumentalis was wat ander sangers op sy albums gebruik het). Hy het 'n ongelooflike 1000000 langspeelplate in minder as vyf jaar in die laat 1950's alleen verkoop. Al Debbo het 'n massiewe treffer gehad met Carstens en Anton de Waal se "Hasie", wat meer as 100000 kopieë in die vroeë 1950's verkoop het. Die Briels het baie gewilde sentimentele liedjies in die 1950's en 60's uitgereik. Ander groot name was Gé Korsten wat op die toneel gekom het in die 1960's en 'n topverkoper saam met Min Shaw gehad het op die klankbaan van die rolprent Hoor my lied in 1968. Shaw het self 'n baie suksesvolle musikale vennootskap gehad met die country-sanger Lance James in die 1960's. Groep Twee, met Gert van Tonder en Sias Reinecke, het verskeie treffers gehad in die 1960's en 70's. Hendrik Susan was besonder gewild vanaf die laat 1930's tot die vroeë 50's. In die 1930's was Chris Blignaut (wat ook meer as 'n miljoen albums in sy leeftyd verkoop het) en David de Lange (wat meer as 300000 kopieë van "Suikerbossie" verkoop het in 1936) die groot name in Afrikaanse musiek. Cissie en Willie Cooper was ook belangrik in daardie era, asook Danie Bosman. Dit is nodig om die hoofstroom-Afrikaanse kunstenaars van die era ná apartheid met hierdie kunstenaars in verband te bring.

Hoewel dit baie gewild is, waardeer nie almal hoofstroom- Afrikaanse musiek nie. Jury het dit in die verbygang genoem tesame met onvleiende byvoeglike naamwoorde soos "afgesaag en banaal", ${ }^{43}$ terwyl Byerly dit as "vervelig" 44 bestempel het in vergelyking met ander plaaslike (insluitende Afrikaanse) genres. Beide bronne is vroeë studies van die Suid-Afrikaanse musiektoneel van die laaste jare van apartheid. Jury het die mees oppervlakkige Afrikaanse popsterre van die tyd in beeld gebring, terwyl Byerly gekyk het na 'n wyer groep kunstenaars wat alternatiewe Afrikaanse musikante ingesluit het. Hulle menings oor Afrikaanse pop het beslis meriete, maar mens moet ook verder kyk as na die lae artistieke inhoud van die genre en die sosiale betekenis daarvan in ag neem. Die kunstenaars wat hierdie groep verteenwoordig is baie goed daarmee om "begeerte" - om te leen by Michael Drewett ${ }^{45}$ - te verpak vir verbruik deur die meerderheid van wit Afrikaners. Robuuste verkoopsyfers tesame met hul hoë profiele in die massamedia, soos om sportspanne te steun en in rolprente (die eerste een wat dit gedoen het was Chris Blignaut in 1931 toe hy in Sarie Marais gespeel het) en TV-reekse te speel maak dat Afrikaanse popsterre van die mees herkenbare Afrikaanse openbare figure van die hede en verlede is. Hierdie hoofstroom sê soveel meer oor Afrikaners as wat een liedjie oor 'n Boere- generaal wat lank reeds dood is kan doen.

\section{Die agtergrond van taalpolitiek}

Die geskiedenis van Afrikaanse musiekopnames wat terugdateer na die begin van die twintigste eeu getuig van die komplekse sosio-politieke agtergrond van die ontwikkeling van die taal self, 'n onderwerp waaroor daar al dikwels geskryf is maar wat steeds kortliks kommentaar

43 Jury, "Boys to men", p. 99.

44 I. Byerly, "Mirror, Mediator, and Prophet: The Music Indaba of Late-Apartheid South Africa", Ethnomusicology, 42:1 (1998), p. 14.

45 "Packaging Desires: Album covers and the presentation of apartheid", in G. Olwage (red.), Composing Apartheid: Music for and Against Apartheid (Johannesburg: Wits University Press, 2008), pp. 115-135. 
hier verdien. ${ }^{46}$ Dit is wel 'n komplekse kwessie, veral omdat dit 'n groot bron van trots vir, en een van die hoekstene van, wit Afrikanernasionalistiese mitologie van die 1930's af was. ${ }^{47}$ Aansprake van rasse- en taalsuiwerheid wat gekonseptualiseer is om 'n politieke doel te dien het 'n tyd gelede reeds plek gemaak vir etno-linguistiese verduidelikings wat onbelemmerd is deur sulke agendas. Die komplekse ontwikkeling van Afrikaans was teen die einde van die negentiende eeu reeds aan die gang en die duidelike differensiasie tussen die drie oorspronklike groepe wat by die ontwikkeling betrokke was - Europese setlaars, die Khoikhoi en Maleise slawe - het verweer. ${ }^{48}$ Hierdie verwering het nie heeltemal uitgekom by ware kreolisering nie weens die rasse-onderdrukking en magspel wat meer van 'n weerspieëling was van die koloniale rashiërargie as van "egalige en sagte handeling wat gemeenskappe voortbring wat harmonieus in hul pluraliteit is". ${ }^{49}$

'n Sentrale tema was die historiese rasoorheersing van die Hollandse kolonialiste wat hul taal op die ingevoerde slawe en plaaslike bevolking afgedwing het. ${ }^{50}$ Hollands was, danksy die Statenbijbel, dominant in godsdienspraktyke en witmense se kleurbewustheid het die proses verder beperk. ${ }^{51}$ Ten spyte van hierdie rashiërargie het die diverse historiese oorsprong 'n invloed gehad daarop om verskeie grade van kulturele differensiasie onder Afrikaanssprekendes teweeg te bring. Die taal het die moedertaal geword vir Christene en Moslems, van witmense, bruinmense en swartmense, in die stede en op die plase, van werkers en grondeienaars. Die eerste geskrewe teks was in twee verskillede alfabette: Arabies en Romeins. ${ }^{52}$ Dit was egter 'n spesifieke groep wit Afrikaanssprekendes in die tweede helfte van die negentiende eeu wat intiem gewerk het aan die vestiging van 'n linguistiese identiteit wat die gemengde rasoorsprong van die taal ontken het. Hulle was baie sensitief oor die beskuldiging dat Afrikaans die verbasterde taal van die "Hotnots" en die "Asiese en Mosambiekse bediendes" 53 is. Teen die koloniale agtergrond wat sy oog op Europa gehad en enigiets van Afrika die rug toegekeer het, het hulle geveg vir die rassuiwerheid van die taal, en daarmee die Afrika-elemente daarvan verwerp..$^{54}$

46 Die skakel tussen Afrikaanse taalontwikkeling en Afrikaanse populêre musiek is voorheen deur die outeur aangespreek in "Kruger's lost voice: Nation and race in pre-World War1 Afrikaans music records", Historia, 6:1 (2015), pp. 110-128.

47 Sien byvoorbeeld E.C. Pienaar, Die Triomf van Afrikaans: Historiese oorsig van die wording, ontwikkeling, skriftelike gebruik en geleidelike erkenning van ons Taal (Kaapstad: Nasionale Pers, 1943) en M.S. du Buisson, Die Wonder van Afrikaans: Bydraes oor die ontstaan en groei van Afrikaans tot volwaardige Wêreldtaal (Johannesburg: Voortrekkerpers, 1959).

48 P. Roberge, “The Formation of Afrikaans”, Stellenbosch Papers in Linguistics, 27 (1993), p. 48.

49 D. Martin, Sounding the Cape: Music, Identity and Politics in South Africa (Somerset-Wes: African Minds, 2013), p. 55.

50 G. Stell, X. Luffin en M. Rakiep, "Religious and secular Cape Malay Afrikaans: Literary varieties used by Shaykh Hanif Edwards (1906-1958)", Bijdragen tot de Taal-, Land- en Volkenkunde, 163:2/3 (2007), p. 289.

51 F. Ponelis, “The Development of Afrikaans”, in R. Dirven, M. Pütz and S. Jäger (reds.), Duisberg Papers on Research in Language and Culture Vol. 18 (Frankfurt: Peter Lang, 1993), p. 69.

52 Stell, Luffin en Rakiep, "Religious and secular Cape Malay Afrikaans: Literary varieties used by Shaykh Hanif Edwards (1906-1958)”, p. 289.

53 J. van Wyk, "Afrikaans Language, Literature and Identity", Theoria: A Journal of Social and Political Theory 77, (May 1991), p. 85.

54 Ibid. 
Die wit weergawe van Afrikaans wat verrys het moes dus die invloed van die rasgebaseerde "ander" kon weerstaan om sy Europese kulturele identiteit te behou en terselfdertyd die uitdagings van Britse imperialisme die hoof bied. ${ }^{55}$ Die linguistiese ontwikkeling van Afrikaans toon noemenswaardige ooreenkomste met die ontwikkeling van Afrikaanse musiek, wat aan soortgelyke sosiale kragte onderhewig was. Die diverse kulturele erfenis het musiek ingesluit wat gesing is in Afrikaans en gespeel is deur musikante van regoor die rasspektrum..$^{56}$ Ingevoerde Hollandse en Duitse (en tot 'n mindere mate Engelse) liturgiese en sekulêre liedjies het hulle merk gemaak, en so ook die Amerikaanse minstrel-liedere wat na die kolonie gebring is in die laaste deel van die negentiende eeu. Dit is hier vertaal en gedeeltelik gekreoloseer in die ontluikende streekstaal. ${ }^{57}$ Tradisionele boeremusiek het veral 'n ingewikkelde mengsel van die stedelike en landelike en van ras en klas verteenwoordig - baie soos die taal self. ${ }^{58}$ Maar toe dit kom by opgeneemde Afrikaanse musiek was daar 'n aantal struikelblokke vir bruin en swart Afrikaanssprekendes. Die eerste Afrikaanse musiekopnames (voor 1912) was byvoorbeeld - behalwe van die Springbok-rugbytoergroep - meesal gedoen deur Afrikaanssprekendes wat beurse kon kry om in Londen te studeer. Sulke geleenthede was bitterlik skaars vir bruin en swart Afrikaanssprekendes in daardie era. Bruin en swart Afrikaanse musikante het, ten spyte van 'n ryk en unieke musiekherkoms (veral in die Kaap), buitestanders van die Afrikaanse musiekbedryf gebly vir die grootste deel van die twintigste eeu. Tydens die opkoms van 'n nuwe fase van Afrikanernasionalisme van die 1930's af was dit selfs nog minder in die belang van die ideoloë om hierdie gedeelde musiekgeskiedenis te bewaar.

Hierdie lang geskiedenis van skeiding het 'n langdurige uitwerking gehad op Afrikaanse musiek. Teen 2017 was die hoofstroom steeds oorweldigend wit en dien dit spesifiek 'n hoofsaaklik wit gehoor al is wit eerstetaal Afrikaanssprekers die minderheid. Hoewel 'n mens sekerlik kan argumenteer dat die Afrikaanse musiekopnamebedryf gedryf word, en altyd gedryf sal word, deur die winsmodel, het dit sonder twyfel gefunksioneer - teen verskillende grade van toegeeflikheid, wat ondersoek behoort te word - binne die grense wat gestel is deur 'n sosio-politieke geskiedenis van uitsluiting. Dit het meesal geneig om die multi-rassige wortels van baie Afrikaanse musiek-genres, asook belangrike areas van musiekinnovering buite hoofstroom-Afrikaanse musiek, te ignoreer en te ontken. Hierdie sterilisering van "ander" invloede was nie altyd suksesvol nie. Sekere genres van populêre musiek, soos kwêla, het byvoorbeeld tekens getoon dat dit sulke soort skeidings kon teenstaan in 'n tyd van groeiende rassegregasie. Afrikaanse opnames het meesal nie die bydrae van bruin Afrikaanse musikante gereflekteer nie. Wit Afrikaanssprekendes het histories die Afrikaanse musiekbedryf oorheers in terme van uitset en verbruik. Afrikaanse taalpolitiek het boonop die Afrikaanse musiekbedryf oorheers sedert die heel eerste opnames van Afrikaanse musiek. Die geskiedenis van opgeneemde populêre Afrikaanse musiek wissel van gedeelde spasies tussen rassegroepe en hulle musiek (waar die rashiërargie wat in die breër samelewing bestaan - deur verskeie historiese faktore - nie noodwendig van toepassing is nie) tot 'n afgewitte fokus op Wes-Europa, wat vertaalde Schlager-musiek insluit.

55 L. Witz, Apartheid's Festivals: Contesting South Africa's National Pasts (Bloomington: Indiana University Press, 2003), p. 13.

56 Martin, Sounding the Cape, pp. 69-92.

57 J. Bouws, Solank daar musiek is: musiek en musiekmakers in Suid-Afrika (1652-1982) (Kaapstad: Tafelberg, 1982).

58 W. Froneman, Pleasure Beyond the Call of Duty: Perspectives, Retrospectives and Speculations on Boeremusiek, ongepubliseerde D.Phil tesis, Universiteit Stellenbosch, 2012, pp. 49-62. 


\section{Schlager}

Teen die 1960's was dit standaardpraktyk in die hoofstroom- Afrikaanse musiek om Europese Schlager- ("treffer") melodieë te vat en Afrikaanse lirieke daarvoor te skryf. Selfs nog voor Schlager het Afrikaanse sangers Afrikaanse lirieke vir ander oorspronklike komposisies in ander tale opgeneem. Gallo het kunstenaars Londen toe gestuur om 'n klomp Afrikaanse liedjies op te neem wat uiteindelik Afrikaanse weergawes van Engelse treffers ook ingesluit het, waarskynlik weens 'n gebrek aan oorspronklike materiaal. Selfs nog vroeër, in 1910, het Annie Visser Afrikaanse Gezangen oor Engelse gesange opgeneem, wat kopiereggevolge gehad het ingevolge die nuwe wette van $1912 .{ }^{59}$ Hierdie praktyk is vandag steeds in gebruik..$^{60}$

Schlager is al dekades lank'n gewilde pop-genre in Noord-Europa en het verskeie vorme aangeneem in lande soos Finland, Hongarye, Swede, Turkye, Oostenryk, Nederland, Duitsland en die voormalige Joego-Slawië. Hollandse, Duitse en Oostenrykse Schlager was skynbaar die gewildste onder Afrikaanse kunstenaars. ${ }^{61}$

Schlager was nie vreeslik gewild in Brittanje en Amerika nie, waarskynlik weens die groot hoeveelheid ander genres van populêre musiek. Die Europese melodieë met Afrikaanse lirieke val onder die klas van Afrikaanse lekkerliedjies (lekker om na te luister met oppervlakkige lirieke). Vanaf die laat 1970's, maar veral van die 1980's af aan, is lekkerliedjies kwaai gekritiseer deur die meer ernstige Afrikaanse liedjieskrywers en joernaliste. Akademici het die lekkerliedjies gekritiseer weens die oppervlakkigheid, maar meer belangrik, vir die inskiklikheid daarvan met die apartheid-regime. ${ }^{62}$ Die kritiek teen die lekkerliedjie is soortgelyk aan die kritiek, spesifiek in Duitsland, teen Schlager. Schlager in verskeie ontwikkelende vorme is sedert die 1950's 'n gewilde genre in Duitsland, maar dit het kritiek van Duitse musikante en die skrywers van meer gesofistikeerde musiek ontlok. Klaus Nathaus se studie werp lig op hoe hierdie genre deur'n stelsel van "payola" (om platejoggies te betaal om liedjies oor die radio te speel) bevoordeel is deur die hekwagters van die musiekbedryf tot nadeel van ander, meer dinamiese musiekstyle. ${ }^{63}$ Hy definieer Schlager as:

... a form of music that aimed at a mass audience unable or unwilling to discriminate by means of artistic criteria. Hit songs were devised to charm, amuse or move the broadest possible spectrum of people with catchy melodies and uncontroversial lyrics. Most hit songs dealt with romantic love; other Schlager referred to sunny and more or less exotic places from Italy to Hawaii or latched on to novelties in a quirky way. ${ }^{64}$

59 Sien Hoofstuk Een.

60 Kosie van Niekerk (hoof van Select-platemaatskappy), in Roggeband, 50 Stemme, p. 157.

61 D.C. Pretorius, Musieksterre Van Gister En Vandag: lewensketse en foto's van meer as 100 musieksterre. (Pretoria: Van der Walt, 1998), pp. 271-275.

62 Jury, "Boys to men", pp. 99-100; Byerly, “Mirror, Mediator and Prophet", p. 14.

63 K. Nathaus, "From dance bands to radio and records: Pop music promotion in West Germany and the decline of the Schlager genre, 1945-1964", Popular Music History, 6:3 (2011), pp. 287-306.

64 Ibid., p. 292 
Hierdie definisie van Schlager is baie soortgelyk aan die meeste kommersiële ligte Afrikaanse musiek wat sedert die 1950's uitgereik is. In Europa het meer vaardige musikante neergesien op Schlager en meer uitdagende genres soos jazz verkies. 'n Vername kritikus van Schlager was die jazz- publisiteitsagent Alfred Baresel. Hy het in 1964 gesê dit is aktief deur Joseph Goebels bemark deur die organisasie Kraft durch Freude (Mag vanuit vreugde) tydens die Tweede Wêreldoorlog. ${ }^{65}$ Volgens Baresel is sentimentele liedjies gebruik om die bevolking kalm te hou tydens die oorlog. Op daardie manier is Schlager beskou as iets "skadeliks" eerder as iets "waardeloos".66

Dit toon 'n merkwaardige verband met die stand van die Afrikaanse musiekbedryf tydens die later jare van apartheid. Die idee van Schlager-musiek as 'n instrument om die bevolking te beheer in tye van nasionale bedreiging is dalk 'n ekstreme beskuldiging. Maar as 'n mens Carike Keuzenkamp se vertaalde Schlager-treffer "Dis 'n Land" tesame met die tydsberekening van die uitreik daarvan (tydens die derde jaar van die noodtoestand in 1987) beskou, asook die meegaande musiekvideo, lyk die beskuldig heeltemal geldig en toepaslik. Die beelde in die video is aangrypend: tonele van die apartheid-regime se militêre mag tydens 'n geweldig plofbare politieke tydperk wat vir die Afrikaanse luisteraars en kykers 'n onsubtiele boodskap gestuur het dat hulle lewens in goeie en magtige hande is; Suid-Afrikaners van ander rasse is in oënskynlik gelukkige tonele, soos 'n swart paartjie wat lag en dans, die Kaapse Klopse-karnival en plaaswerkers in die Boland wat lyk of hulle doodgelukkig is in hulle armoede. ${ }^{67}$ Dit, tesame met die lirieke, het 'n utopiese beeld van wit Suid-Afrika gewys wat in sterk teenstelling was met die politieke realiteite van die dag. "Dis 'n Land" is gespeel op SAUK (Suid-Afrikaanse Uitsaakorporasie) radio en TV, asook liedjies van onder andere sniksanger Bles Bridges, wat só gewild was onder Afrikaanse gehore dat hy twee aande in die Sun City Superbowl in 1987 kon uitverkoop. ${ }^{68}$ Bridges en ander Afrikaanse kunstenaars soos Gé Korsten het kritiek ontlok van 'n nuwe generasie Afrikaanse kunstenaars in die 1980's. Die Voëlvry-kunstenaars met hulle "Ek verpes Bles" T-hemde was die venynigste. Dit was vergelykbaar met die kritiek van kunstenaars teen die bevoorregte posisie van Schlager in die Duitse musiekbedryf. Dit het ook die kommer versterk dat opsetlik oppervlakkige Afrikaanse musiek 'n negatiwe impak op Afrikaanse kultuur het.

Die gebruik van Afrikaanse Schlager-treffers vir twyfelagtige politieke doeleindes deur die staatsuitsaaier het wel sy beperkinge gehad. Tydens die 1980's wou die SAUK die meer ernstige genre van Afrikaanse kabaret bemark omdat dit beter gepas het by die aspirasie om 'n meer intellektuele Afrikaanse kultuur te ontwikkel. Schlager het nie genoeg klas gehad nie. Die SAUK het ook dikwels sterk standpunt teen Schlager ingeneem omdat hy "egte" Afrikaanse musiek verkies het. ${ }^{69}$ Duitse vanne op die lys van

65 Aangehaal in Nathaus, "From dance bands to radio and records", p. 302.

66 Ibid.

67 http://www.youtube.com/watch?v=8r2uLdSlyg0 [besoek 10 Augustus 2012].

68 Roggeband, 50 Stemme, p. 27.

69 Boet Pretorius, telefoniese onderhoud met outeur, 22 Julie 2013. 
komponiste het die SAUK nie gelukkig gemaak nie. Dit plaas die gebruik van Schlager in perspektief en ondermyn die idee dat die SAUK ingevoerde en herverwerkte Schlager- musiek bo meer plaaslike genres verkies het. Maar die bedryf was klein en met beperkte beskikbare oorspronklike materiaal was die besluit om Europese treffers te vertaal eenvoudig pragmaties, ten spyte van die ooglopende risiko. Die prominente Afrikaanse platemaatskappy Decibel het omtrent twaalf kunstenaars op die boeke gehad in daardie tyd - onder hulle van die grootste name in Afrikaanse musiek soos Gé Korsten, Carike Keuzenkamp, Anneli van Rooyen en Leon Schuster - en daar was net nie genoeg Afrikaanse liedjieskrywers wat treffers kon lewer nie. Twaalf albums bevat minstens 144 liedjies wat gekies word uit vele meer en kunstenaars moes byna elke jaar 'n nuwe album uitreik, wat beteken die hele proses het homself jaarliks herhaal. ${ }^{70}$

Danie Pretorius se lys van die 100 grootste treffers in die geskiedenis van die Afrikaanse musiekbedryf verskaf nuttige inligting oor die oorsprong van populêre Afrikaanse komposisies. ${ }^{71}$ Die lys is gedeeltelik gebaseer op albumverkope, maar sluit ook optredes en radio- en TV-tyd in waar dit van toepassing is. Hy verskaf egter nie spesifieke bronne nie en sluit tradisionele Afrikaanse volksliedjies, boeremusiek en FAK-liedere uit. ${ }^{72}$ Die boek is in 1998 gepubliseer en sluit ook die vlaag van Afrikaanse pop-treffers wat sedert 2000 uitgereik is uit. Van die 100 liedjies op die lys is 36 oorsese komposisies met Afrikaanse lirieke. Vir 'n aantal van hulle is slegs die Afrikaanse liriekskrywer se naam gegee, maar kruisverwysings bevestig dat dit ingevoerde musiek was. ${ }^{73}$ Van die lys van 36 is drie tussen 1930 en 1959 uitgereik, nege in die 1960's, sewe in die 1970's, 14 in die 1980's en twee ná 1990.

$\mathrm{Al}$ agt van Gé Korsten se treffers op die lys kom van oorsee. “Sing, seeman, sing” was 'n aanpassing van 'n Duitse seemanslied, terwyl "Wees lief vir my" oorspronklik 'n liedjie van die Oostenrykse komponis Udo Jürgens was. ${ }^{74}$ Behalwe vir hierdie bekende treffers was die gebruik om Afrikaanse lirieke vir Europese treffers te skryf baie algemeen. Individue soos Heine Toerien (wat vir die SAUK gewerk het) ${ }^{75}$ en André Viljoen ${ }^{76}$ is gereeld deur die platemaatskappy Brigadiers ingespan om lirieke vir Afrikaanse sangers te skryf. As 'n mens dit lees tesame met die 2012-uitgawe van die FAK-liedereboek, ${ }^{77}$ wat ook 'n lys van die gewildste Afrikaanse musiek bevat en wat die liedjieskrywers lys, kom 'n duidelike prentjie van die oorsprong van baie Afrikaanse liedjies na vore. Daar is 'n geneigdheid om liedjies van kontinentale Europa te verkies - waar Schlager

70 Ibid.

71 Pretorius, Musieksterre Van Gister En Vandag, pp. 271-275.

72 Ibid.

73 'n Voorbeeld is Carike Keuzenkamp se 1987 treffer, "Dis 'n Land”, met lirieke deur Johan Stemmett. Die musiek is geneem van die Duitse sanger Nicole se 1986 treffer, Laß mich nicht allein. http://www.youtube.com/watch?v=qWONEFve-bY [besoek 10 Augustus 2012].

74 Pretorius, Musieksterre Van Gister En Vandag, pp. 271-275.

75 http://www.sahistory.org.za/dated-event/heine-toerien-71-afrikaans-broadcaster-and-author-entertainmentprograms [besoek 9 August 2013].

76 http://www.vetseun.co.za/anarkans/bladsy/generockwell.html [besoek 9 August 2013].

77 Federasie van Afrikaanse Kultuurvereniginge, FAK-sangbundel: ' $n$ versameling van Afrikaanse musiek in ses verskillende rubrieke Vol. II (Pretoria: Federasie van Afrikaanse Kultuurvereninge, 2012). 
gewild is - bo Britse en Amerikaanse musiek. Hierdie tendens het nog nie gestop nie. In 'n artikel in Die Huisgenoot Tempo haal Roggeband die volgende verklaring deur 'n anonieme SAMA- (Suid-Afrikaanse Musiektoekennings) beoordelaar aan in 2012:

As jy luister na die tipe musiek wat die res van die Suid-Afrikaanse kunstenaars bied besef mens hoe ver agter ons is. Van die Afrikaanse albums klink asof dit ses of selfs sewe jaar terug opgeneem is. Daar word te veel gesteun op die leen van oorsese liedjies. ${ }^{78}$

'n Meer onlangse voorbeeld is Nicholis Louw se 2008-treffer "Vergeet en Vergewe".79 Die musiek van nog een van sy treffers - "Rock daai lyfie" - was die selfoondeuntjie van een van die sekretaresses by sy platemaatskappy. Meer as 100000 kopieë van die album is verkoop. ${ }^{80}$ Kosie van Niekerk van Select Music en mede-skrywer van talle Afrikaanse pop-treffers erken ruiterlik dat hulle nie bang is om liedjies van oorsee oor te vat nie, want musiek is universeel..$^{81}$ In 'n interessante ommekeer het Kurt Darren weer 'n aantal van sý liedjies verkoop aan Vlaamse en Duitse kunstenaars. ${ }^{82}$

\section{Kultuurpolitiek}

Om terug te keer na die sentraliteit van die woord volk, het die skep van die Afrikaner-"nasie" - die basis van Afrikanernasionalisme - 'n reuse-uitwerking op die lewe van Afrikaanssprekendes gehad. Die Afrikaanse taalbewegings van die laat negentiende en vroeë twintigste eeu het gehelp om Afrikaans te differensieer (spesifiek 'n wit weergawe van die taal) van Hollands en die taal het 'n kritieke element in die ontluikende self-identifisering van mense wat hulleself "Afrikaners" genoem het, geword. Veral in die 1930's was taal, ras en geloof die hoekstene waarop Afrikaner-kulturele entrepreneurs gebou het aan 'n nuwe vorm van Afrikanernasionalistiese mitologie wat die magsbasis geword het van D.F. Malan se Gesuiwerde Nasionale Party. Sentraal tot die proses was die konstruk van die self in teenstelling met die "ander": wit Suid-Afrikaners (Engelssprekendes), maar, van kritieke belang, ook ander rasse. Kulturele identiteit is afhanklik van Afrikanerkultuurkonstruksies, en musiek is gebruik om kulturele egtheid te vestig gebaseer op die volkseie teenoor die volksvreemde. ${ }^{83}$ Dit het 'n invloed gehad op die proses van die aanvaarding waardeur boeremusiek in die 1940's en 50's gegaan het (wat bespreek word in Hoofstuk Drie). Hierdie foutlyne manifesteer meer dikwels in populêre Afrikaanse musiek regdeur die twintigste eeu (en tot in die 21ste) as wat tot op hede in die literatuur voorgestel is. Die verband tussen musiek en identiteit is sterk. Martin verduidelik dat die sosiale raamwerk van musiek word gevorm deur dieselfde boublokke - "geskiedenis, ruimte en kultuur" - as wat mense se identiteit gevorm word. Dit beteken dat "musikale verskille interpreteer word as sosiale verskille" ${ }^{84}$

78 Die Huisgenoot Tempo 1 (2012), p. 21.

79 Roggeband, 50 Stemme, p. 203.

80 Ibid.

81 Ibid., p. 157.

82 Ibid., p. 159.

83 Laubscher, "Afrikaner identity and the music of Johannes Kerkorrel”, p. 313.

84 Martin, Sounding the Cape, p. 21. 
Daar is beslis geen tekort aan voorbeelde van hoe verdelend menings oor hoofstroom-Afrikaanse musiek oor die jare was nie. In die algemeen, onder diegene in die akademie en kunstenaars, word aanvaar dat dit min bygedra het tot Suid-Afrika se musiekerfenis. Afrikaanse liedjies wat artistieke grense uitdaag verkoop meesal nie. In 'n koerantartikel in 2009 skryf Anton Goosen, een van die mees invloedryke Afrikaanse liedjieskrywers van die laaste vier dekades, oor sy ontsteltenis oor wat hy noem die "riool"-gehalte van Afrikaanse pop wat geleidelik die kommersiële Afkrikaanse mark infiltreer het ${ }^{85} \mathrm{Hy}$ maak drie aannames: eerstens dat Afrikaanse musiek voor Musiek-en-Liriek gedomineer is deur vertaalde Europese "oempa"-musiek wat opgevreet is deur 'n ongesofistikeerde gehoor; tweedens dat kunstenaars in die 1980's baie beperk is deur die regime via die sensuurraad en dat die regime die nuwe musiekbewegings probeer kaap het, wat gelei het tot die vervlakking van Afrikaanse musiek teen die laat 80's; en derdens dat die vervlakking ná 1994 voortgegaan het met die sentimentele nostalgie en kommersialisering tot by die punt waar populêre Afrikaanse musiek nou 'n permanente plek in die moddersloot ingeneem het. Van die sterkste kritiek teen hoofstroom-Afrikaanse musiek het in 2012 gekom vanaf die skrywer en dokumentêre filmmaker Deon Maas, wat ook vir een van die grootste platemaatskappy gewerk het:

Die Afrikaanse mark is al die afgelope dekade ' $n$ vullisdrom vir talentlose mense wat die vermtelheid het om hulleself as musikante te beskryf. ${ }^{86}$

Neerhalende opmerkings gemik op Afrikaanse popsangers het by tye nie net die verskille in artistieke waardes en meriete gesimboliseer nie, maar ook politieke affiliasie. 'n Klassieke voorbeeld hiervan het gebeur in Pretoria op 31 Mei 1990. Op daardie dag is die eerste Houtstok ('n verwysing na "Woodstock") gehou op 'n plaas buite die stad terwyl die Federasie van Afrikaanse Kultuurverenigings (FAK) Republiekdag gevier het by die Voortrekkermonument. ${ }^{87}$ By Houtstok het "alternatiewe" Afrikaanse musikante - 'n losweg gedefinieerde groep anti-establishment Afrikaanse rock en punk-groepe ${ }^{88}$ - gespeel voor 'n gehoor van meesal jong Afrikaners wat (in die algemeen) nie die ideologie van die staat aangehang het nie. Dit was in skrille kontras met die hoofstroom-Afrikaanse popkunstenaars wat by die FAK se konsert opgetree het en nie net backtracks gebruik het nie, maar boonop "ge-lip sync" het en 'n meer konserwatiewe groep Afrikaners vermak het by die viering van Afrikanernasionalisme. Dit het Afrikaanse pop as polities inskiklik gevestig, terwyl alternatiewe Afrikaanse kunstenaars nie net artistiek meerderwaardig was nie, maar ook polities gekant was teen apartheid. Hierdie verdeling is natuurlik grof. Daar is meriete daarin om Afrikaanse pop as 'n inskiklike deel van die dominante taal van apartheid-ideologie te beskou, ${ }^{89}$ maar dit spreek nie gevalle van spanning tussen Afrikaanse popsangers en apartheidsideoloë aan nie. En beskuldigings dat Afrikaanse pop, weens die onkonfronterende aard daarvan, rassistiese Afrikaner-heerskappy tydens apartheid gesteun het mis die punt dat plaaslike pop in ander tale dikwels dieselfde

85 "Afrikaanse musiek stamp-stamp tot in die rioolsloot", Rapport, 13 Junie 2009.

86 Roggeband, Die Huisgenoot Tempo 1 (2012), p. 18.

87 A. Arnold, "Veertien uur se rock by Houtstok", Insig (Mei 1990), p. 37; J. Goodwin en B. Schiff, Heart of Whiteness: Afrikaners face black rule in the New South Africa (New York: Scribner, 1995), pp. 174-183.

88 Daar was ook Engelssprekende kunstenaars op die program, soos Jennifer Ferguson en No Friends of Harry.

89 Ibid. 
gedoen het weens sensuur en beperkinge wat op die musiekbedryf geplaas is. 'n Meer sinvolle ondersoek sou wees om die breër kontoere van die Suid-Afrikaanse gemeenskap en hoe dit die plaaslike musiekbedryf in geheel beïnvloed het te bekyk.

Die fokus van hierdie boek was oorspronklik veronderstel om te wees op die era ná apartheid (wat netjies saamval met my eie loopbaan) wat, as 'n mens pedanties daaroor wil wees, die Voëlvry-beweging sou moes uitsluit aangesien dit in 1989 gebeur het. Maar geen boek oor populêre Afrikaanse musiek wat sy sout werd is kan so 'n weglating waag nie. Maar as 'n mens dan besluit om Voëlvry in te sluit, moet 'n mens die onstuimige politiek in die jare wat dit voorafgegaan het noem en dan moet 'n mens dalk begin met Musiek-en-Liriek in 1979. Nog vrae het gevolg. Wat van die Afrikaanse musiek wat gemaak is tydens die hoogtepunt van apartheid in die 1960's en 70's? Of hoe die segregasiewetgewing van die 1950's musiekoptredes en -opnames beïnvloed het? 'n Mens kan ook nie die 1930's uitsluit nie, want dit was 'n besonder belangrike dekade vir Afrikaanse musiek en vir Suid-Afrikaanse radio met die stigting van die SAUK in 1936. En so het 'n proses van terugdatering begin wat, as jy die logika volg dat so 'n wye projek netsowel by die heel begin kan begin, verander het in 'n soektog na die oudste Afrikaanse plate. 


\section{HOOFSTUK EEN}

\section{Grammofone, "warm patriotte" en radio-0orloë}

\section{Die eerste klankopname van Afrikaans ${ }^{1}$}

Voordat hy sy roeping as 'n fotograaf van die lewe en argitektuur in en om die Kaap in 1900 gevind het, het Arthur Elliot 'n dekade lank in Suid-Afrika rondgeswerf en los werkies gedoen, meesal in die teater waar hy agtergronde geverf het of bestuurder was. Deur sy betrokkenheid met die vermaaklikheidsbedryf het hy die eerste fonograaf Transvaal toe gebring en hy is aangewys om 'n skare van beroemdes, onder andere Paul Kruger, in Pretoria te vermaak een aand in die 1890's. ${ }^{2}$ Hoewel Lighton in sy biografie oor Elliott nooit eksplisiet noem dat Elliott daardie aand opnames gemaak het nie (die fonograaf is hoofsaaklik gebruik om musiek te speel maar kon ook opneem) het Eric Rosenthal verwys na 'n geleentheid waar hy wel Kruger se stem opgeneem het op 'n "primitiewe, silindriese toestel" wat daarna weggeraak het en daarmee saam waarskynlik ook die eerste klankopname in die Afrikaanse taal. ${ }^{3}$ Dit is wel te betwyfel of dit 'n musiekopname was, aangesien Kruger nie bekend was vir sy sangtalent nie.

1 'n Vekorte weergawe van hierdie hoofstuk is reeds deur die outeur gepubliseer in artikelvorm as "Kruger's lost voice: Nation and race in pre-World War I Afrikaans music records”, Historia, 6:1 (2015), pp. 110-128.

2 C. Lighton, Arthur Elliott: A memoir of the man and the story of his photographic collection, (Kaapstad: A.A Balkema, 1956), pp. 34-35. Lighton gee die datum as 1891, wat te vroeg is, want kommersiële fonograwe is eers later uitgerol. Boonop is die Britse diplomaat Sir William Conyngham Greene eers in 1896 na Pretoria verplaas, en dié geleentheid is gehou ter ere van sy vrou, Lady Greene (na wie 'n roos terloops vernoem is). Dit moes dus plaasgevind het tussen 1896 en, waarskynlik, voor die begin van die oorlog in 1899 .

3 E. Rosenthal, Encyclopaedia of Southern Africa (Londen: Frederick Warne \& Co. 1967, Fourth Edition), p. 170. 
Die fonograaf is in 1877 deur Thomas Edison ontwerp maar het vinnig uit die mode geraak weens die koms van die grammofoonspeler danksy die werk van die Duitse uitvinder Emile Berliner. ${ }^{4}$ Vanaf die laat 1890's het opname-ingenieurs, of - "experts", met hulle mobiele grammofoon-opnamemasjiene die wêreld vol gereis om nie net musiek nie, maar ook talle ander vorme van volkskultuur op te neem. Een van die mees bekende pioniers in die gebied was die Amerikaner Fred Gaisberg, wat gewerk het as Berliner se toesighouer voordat hy Londen toe getrek het om aan te sluit by die nuutgestigte Gramophone Record-platemaatskappy in 1898 . Gaisberg was 'n talentuitsnuffelaar en opname-ingenieur en hy het talle opnames reg oor Europe (tot selfs so ver soos Nizhny Novgorod in Rusland) van 1898-1902 gemaak. ${ }^{5}$ In September 1902, vergesel deur George Walter Dillnutt, het hy na die Ooste vertrek waar hulle verskeie opnames gemaak het wat nou waardevolle versamelaarsitems is. Gaisberg het in sy dagboek gedetailleerde notas gemaak van opnames wat in Kolkata, Tokio, Sjangai, Hongkong, Singapoer, Bangkok en Rangoen gemaak is. ${ }^{6}$ Dillnutt is van belang want ná sy talle reise na ander eksotiese plekke het hy uiteindelik in 1912 in Suid-Afrika beland om die eerste grammofoonopnames hier te maak. Elliot het in 1900 Kaap toe getrek en sy loopbaan as fotograaf begin, waarvoor hy beroemd geraak het. Hy het wel af en toe 'n opname op sy fonograaf gemaak (Lighton noem een opname in 1921 van 'n solo-fagotvertoning deur William J. Pickerill, wat later 'n bekende dirigent geword het), maar meer vir private as vir kommersiële doeleindes. ${ }^{7}$ In 1926 het hy selfs 'n agent geword vir Edison Amberola Phonographs - 'n verbetering op die ou prototipe - maar dit was nie baie suksesvol nie. ${ }^{8}$

Daar was, behalwe vir die rondreisende opname-ingenieurs, ook vaste opname-ateljees in Europa en Amerika waar talle opnames van orkesmusiek en operas gemaak is, maar ook van ligter, meer populêre komposisies en dialoë. Oor die keuse van materiaal was die befaamde diskoloog Alan Kelly van mening dat die meeste opnames van daardie tyd bloot ten doel gehad het om luistergenot te verskaf en om 'n bietjie geld vir die maatskappy in te bring. Van die opnames was egter ernstiger, onder andere opnames van geskiedkundige geleenthede. ${ }^{9}$ Die vroegste jare van die grammofoon-opnamebedryf dateer uit 'n tyd van groot veranderinge vir mense wat Afrikaans gepraat het, grootliks as gevolg van die Anglo-Boereoorlog (1899-1902). Die oorlog was klaarblyklik 'n bron van inspirasie vir talle kontinentale Europeërs. ${ }^{10}$ Pro-boer sentimente het gelei tot die komposisie van gewilde liedjies in meer voor die hand liggende plekke soos Holland en België (weens die linguistiese en kulturele bande met Afrikaans) en ook in minder voor die hand liggende plekke soos Hongarye en Tsjeggo-Slowakye. ${ }^{11}$ Trewhela noem dat die Franse veral deur die Boere inspireer is, waarvan liedere soos "Marche Hérioque des Boers", "Le Patriotisme des Boers", "Boers, Je Vous Salue!" en "Hommage aux Armeées Hérioiques des

4 F.W. Gaisberg, Music on Record (Londen: Robert Hale, 1948).

5 The Fred Gaisberg Diaries, Part 1: USA \& Europe, beskikbaar by http://www.recordingpioneers.com/docs/ GAISBERG_DIARIES_1.pdf [besoek 16 September 2016].

6 Ibid.

7 Lighton, Arthur Elliott, p. 36.

8 Ibid., p. 35.

9 Ibid.

10 J. Bouws, "Nederlandse Komponiste en die Afrikaanse Lied", Die Huisgenoot, 22 November 1946, p. 25.

11 R. Trewhela, Song Safari (Johannesburg: Limelight Press, 1980), p. 26; sien ook Bouws, Die Huisgenoot, 22 November 1946, p. 25. 
Republiques du Transvaal et d'Orange", kan getuig. ${ }^{12}$ Of dit is weens die historiese bande met die Franse Hugenote in Suid-Afrika, of net 'n gedeelde veragting vir die Britte is, is onduidelik. Lüdemann het spesifiek geskryf oor die "Buren-Marsch", 'n Duitse komposisie deur August Bernhard Ueberwasser tussen 1901 en 1904 wat klaarblyklik'n huldeblyk was aan die inwoners van die twee Boererepublieke wat 'n groot deel van die Transvaalse volkslied insluit. ${ }^{13}$ Swanepoel het 'n lys van 350 pro-Afrikaner komposisies wat deur die twee oorloë tussen Boer en Brit (1880-1881 en 1899-1902 onderskeidelik) inspireer is. ${ }^{14}$ Hierdie komposisies het ontstaan reg oor die Westerse wêreld, insluitend Amerika en selfs Rusland. Dit was daarom hoogs waarskynlik dat vroeë grammofoonopnames items sou insluit wat te doene gehad met die gebeure in Suid-Afrika in daardie tyd.

Soos genoem in die inleiding, was hierdie boek nooit oorspronklik bedoel om 'n soektog na die oudste Afrikaanse opnames te bevat nie. Dit het egter stadigaan een van die lonendste, hoewel effens forensiese, ondersoeke in die proses geword. Die Suid-Afrikaanse Musiek Ensiklopedie (hierna SAME) ${ }^{15}$ is 'n gesaghebbende bron wat die mees volledige is en 'n detailleerde diskografie bevat van vroeë Africana en Afrikaanse opnames van 1901-1938. Die samestelling van die SAME in die 1980's was self'n reuse-onderneming. Dit het geskied onder die beskerming van die Raad vir Geesteswetenskaplike Navorsing, onder die leiding van die musiekoloog Jacques Philip Malan, en met die bydraes van verskeie vakkundiges. Venter het 'n deel van haar MA-tesis aan Malan gewy en hom uitgebeeld as die personifikasie van puristiese, Calvinistiese norme wat glipse (na sy mening) in liturgiese musiekstandaarde beskou as 'n lakmoestoets vir die morele standaarde van die Afrikanernasie. Hy het glo opgemerk dat "Hervorming, asook teen-hervorming, gaan altyd hand-aan-hand met musiekhervorming aan albei kante", ${ }^{16}$ wat baie klink soos Sokrates se mening oor musiek en sosiale verandering, wat vroeër genoem is. Ten spyte daarvan dat die SAME hom bepaal het by'n konserwatiewe weergawe van Afrikanernasionalistiese ideologie, wat volgens sommige dalk die SAME bederf het (met betrekking tot wat ingesluit en weggelaat is), ${ }^{17}$ bly die ensiklopedie 'n soliede diskologiese bron. Die vroegste Africana-grammofoonopnames wat genoem word - beide die Transvaalse volkslied - dateer uit 1901. Een was deur die sopraan Betsy Schot in Berlyn en die ander deur die bariton Thomas Denijs in Amsterdam. ${ }^{18}$ Een van die hoofbronne van daardie spesifieke afdeling van die SAME is Roberto Bauer se The new catalogue of historical records, 1898-1908/09, ${ }^{19}$ wat in 1947 gepubliseer is en wat 'n vroeë poging was om 'n volledige katalogus van die honderde duisende grammofoonopnames wat in die eerste dekade van die bedryf se bestaan gemaak is, saam te stel. Nuwe inligting kom egter gereeld aan die lig

12 Trewhela, Song Safari, p. 26.

13 W. Lüdemann, “Buren-Marsch: Die Transvaalse volkslied in Duitse gewaad”, LitNet Akademies, 5:1 (Augustus 2008), pp. 58-67.

14 A. Swanepoel, Music inspired by the Afrikaner cause (1852-1902), with special reference to the Transvaal Volkslied, ongepubliseerde M. Tesis, University van Suid-Afrika, 1979.

15 J.P. Malan (red.), Die Suid-Afrikaanse Musiek Ensiklopedie, Vol. 1, (Kaapstad: Oxford University Press, 1986), pp. 350-385.

16 C. Venter, Tesis, p. 100.

17 V. Erlmann, South African Music Encyclopaedia. Volume II, E to I, Review, African Music Vol. 6, No. 3 (1983), pp. 118-120.

18 Malan (red.), Die Suid-Afrikaanse Musiek Ensiklopedie Vol. 1, p. 405; sien ook Truesound Online Discography Project, beskikbaar by http://www.truesoundtransfers.de/disco.html [besoek 18 Julie 2014].

19 R. Bauer, The new catalogue of historical records, 1898-1908/09 (Michigan: Sidgwick and Jackson, 1947). 
soos wat toegewyde diskoloë deur materiaal sif en bestaande katalogusse aanpas, wat beteken ouer katalogusse, veral as hulle al in 1947 gepubliseer is, verouderd is.$^{20}$ Danksy die internet kan navorsers nou nuwe, opgedateerde katalogusse aanlyn nagaan - 'n hulpbron wat selfs die SAME nie gehad het nie.

Kelly se navorsing oor die Gramophone Concert-platemaatskappy het inligting van onskatbare waarde verskaf oor die vroegste jare van die globable musiekopnamebedryf. ${ }^{21}$ Sedert hierdie maatskappy en sy filiale HMV en Zonophone verantwoordelik was vir die meeste van die vroegste Afrikaanse opnames, is Kelly se katalogusse besonder betekenisvol. Dit is aanlyn beskikbaar by die AHRC Research Centre for the History and Analysis of Recorded Music (CHARM) in die Verenigde Koninkryk wat in 2004 gestig is. ${ }^{22}$ Die Truesound Online Discography Project ${ }^{23}$ is nog 'n aanlyn-argief en bevat byna 400000 matriks-inskrywings van vroeë opnames. Hier het die Zonopoint-katalogus (weereens te danke aan Kelly en opgedateer in 2003) 'n matrikslys van 'n aantal Afrikaner volksliedere wat nog nooit tevore opgeteken is nie en wat voor Denijs en Schot se opnames in 1901 gedoen is, opgelewer. Ongelukkig is sulke katalogusse nie volgens taal of titel georden nie, wat beteken die navorser moet deur honderde duisende inskrywings gaan wat potensieel min kan oplewer. ${ }^{24}$ Dit is belangrik om in ag te neem dat diskografië, hoewel hulle meesal ' $n$ betroubare bron van statistiese inligting is, nie die sosiale konteks van die album se vrystelling of die klankgreep insluit nie - 'n feit wat ons begrip van die musiek beperk. Boonop, as 'n mens heeltemal eerlik is, het hierdie verwysings baie min praktiese waarde as 'n mens nie die orspronklike opname daarvan kan kry nie. Dit is onseker of hulle ooit in Suid-Afrika uitgereik is en as kopieë daarvan nog bestaan, is hulle waarskynlik besig om stof op te gaar op 'n rak êrens in Europa. Behalwe vir nuuskierigheid en 'n motivering om 'n datum te vind vir die vroegste opnames, is hulle hier ingesluit omdat hulle 'n vae verteenwoordiging was van Europese simpatie teenoor die Afrikaners op daardie tydstip. Aan die ander kant was die ontdekking van opnames wat ouer was as die wat gelys is in die SAME, besonder bevredigend op 'n persoonlike vlak. 'n Meer nuttige bron, veral vir inligting oor Suid-Afrikaanse opnames in 1912 en later, is die Suid-Afrikaanse oudioargief, wat foto's en klankgrepe van ou plate wat by private versamelaars gekry is bevat. ${ }^{25}$ 'n Meer volledige prentjie van vroeë Africana en Afrikaanse plate het te voorskyn gekom uit 'n soektoeg deur verskeie opgedateerde katalogusse vir inligting oor voorheen onbekende opnames wat gevoeg is by die bestaande inligting in die SAME. Ou koerantberigte, tydskrifartikels en advertensies het ook belangrike materiaal verskaf.

20 Elektroniese kommunikasie met Alan Kelly, 29 Oktober 2014.

21 The Alan Kelly Matrix Listings, beskikbaar by http://www.normanfield.com/kelly.html [besoek 19 Junie 2014]; sien ook A. Kelly, "Structure of the Gramophone Company and Its Output, HMV and Zonophone, 1898-1954”, (September 2000), p. 3, beskikbaar by The Truesound Online Discography Project, http://www.truesoundtransfers.de/disco.html [besoek 18 Julie 2014].

22 Beskikbaar by http://charm.rhul.ac.uk/index.html.

23 Beskikbaar by http://www.truesoundtransfers.de/disco.html [besoek 18 Julie 2014].

24 Die outeur se soektog het byvoorbeeld omtrent die hele winter van 2014 in beslag geneem en slegs 15 opgelewer. 


\section{So, wie was regtig eerste?}

Van die tienduisende opnames wat reg oor die wêreld gemaak is voor 1905 het net $15^{26}$ 'n Afrikaanse verbintenis, die meeste van hulle het verwysings na die Transvaal en is meesal gesing deur Hollandse sangers. Soos genoem op bladsy een, is dit eerstens opgeneem in Den Haag en Berlyn in Januarie 1900. In Den Haag is "Transvaalsch Volkslied” opgeneem deur J.C. van den Berg, terwyl E. Spieksma (bas) "Transvaal en Nederland" en "Volkslied van den Oranje Vrijstaat" opgeneem het. ${ }^{27}$ In Berlyn het Ewald Brückner (tenoor) en H. Cornelli die "Transvaalsch Volkslied" opgeneem. ${ }^{28}$ So ver as wat bepaal kon word, is hierdie opnames deur Van den Berg, Spieksma, Brükner en Cornelli die oudste Africana-grammofoonopnames en dateer van voor die val van die Transvaal in September 1900. Nog opnames het daarna gevolg. Die Munisipale Militêre Orkes het op 6 Desember 1900 "Boeren Nationale Hymne" in Londen opgeneem..$^{29}$ Op 10 September 1901 het die Kapel van het 7e Regiment Infanterie van Amsterdam "Het Transvaalsch volkslied" en die "Transvaalsch vlaggenlied" opgeneem. ${ }^{30}$ Thomas Denijs het in dieselfde maand sy opnames van "Het Transvaalsch volkslied" en "Transvaalsche Vierkleur" (laasgenoemde is nie in die SAME genoem nie) gemaak in Amsterdam maar die presiese dag is nie bekend nie. ${ }^{31}$ Volgens Grove's Dictionary of Music and Musicians was Denijs 'n klassiek-opgeleide operasanger, een van Holland se bestes, en hy het in 1901 by die Amsterdamse Opera aangesluit. Die meeste van die sangers wat Africana-liedere opgeneem het in hierdie periode, is egter nie in hierdie publikasie ingesluit nie. ${ }^{32}$ 'n Ander weergawe van die volkslied is op 12 September 1902 in Brussels opgeneem deur Jan Teirlynck. ${ }^{33}$

Die amptelike volkslied van die Transvaal was, soos voorheen genoem, “Kent gij dat Volk". Dit is in 1875 geskryf deur die Hollandse edelvrou Catharina van Rees (dit het haar na bewering ses ure geneem) op versoek van haar vriend en President van Transvaal, Thomas Burgers, terwyl hy in Europa getoer het vir staatsake. ${ }^{34}$ Die twee het meer as 20 jaar tevore ontmoet toe Burgers 'n student in Utrecht was, en hulle het in kontak gebly. "Kent gij dat Volk" het regdeur die twintigste eeu 'n gewilde lied gebly wat altyd met Afrikanernasionalisme verbind is. Behalwe vir die volkslied, is ander liedere oor die Tranvaal ook in hierdie tydperk opgeneem. Die komedie-sanger Jan Willekens het "Vredelied over Transvaal" op dieselfde dag opgeneem, moontlik in dieselfde ateljee waar Teirlynck die Tranvaalse Volkslied opgeneem het. ${ }^{36}$ 'n

26 Hierdie afleiding is gemaak nadat 'n verskeidenheid matriks-inskrywings geraadpleeg is. Dit is moontlik dat daar meer is omdat die inskrywings onvolledig is.

27 Diskografiese data versamel deur Alan Kelly, beskikbaar by The CHARM Discography, <http://www.charm.kcl. ac.uk/discography/search/disco_search> [besoek Mei-Oktober 2014]; sien ook Robert Johannesson se katalogus by http://78opera.com/files/ARTIST_Se-Sz.pdf [besoek 17 Maart 2017].

28 Alan Kelly Catalogue, http://charm.rhul.ac.uk/index.html [besoek Mei-Oktober 2014].

29 Ibid.

30 Ibid.

31 Ibid.

32 E. Blom (red.), Grove’s Dictionary of Music and Musicians Vol. 11 (Londen: Macmillan, 1954), p. 665.

33 http://www.truesoundtransfers.de/disco.html [besoek 18 Julie 2014].

34 A.M. Swanepoel, "Music inspired by the Afrikaner cause (1852-1902), with special reference to the Transvaal Volkslied, Volume 1", MA Tesis, Universiteit van Suid-Afrika, 1979, p. 218.

35 Ibid., p. 212.

36 http://www.truesoundtransfers.de/disco.html [besoek 18 Julie 2014]. 
Moontlike vroeër opname, "Wat zien we in Transvaal", is in Brussels gemaak deur die bariton en komediant Louis Verstraeten, in 1901 of 1902.37 Die Hollandse bariton Arnold Spoel het "Vereenigd Afrika", sy eie komposisie, in Brussels opgeneem in $1904 .{ }^{38}$ Spoel het dit opgedra "Aan de helden der Transvaal"39 in 1899 en aan Paul Kruger geskenk met sy aankoms in Den Haag in 1901 gedurende sy ballingskap. ${ }^{40}$

Hoewel die liedere meesal deur klassiek-opgeleide Europese sangers opgeneem is en nie deur Afrikaners gesing is nie, het hulle verhouding met die politiek en die mense van die Boererepublieke hulle steun vir Afrikaner-onafhanlikheid gewys. Hulle is ook ideologies verbind aan Suid-Afrikaanse komposisies wat in die subteks die lig gewerp het op die spanning tussen wit Afrikaanssprekendes wat gedryf is deur geografiese en klasverskille. Met die aanvang van die twintigste eeu het baie Afrikaners steeds gevoel Hollands is hul eerste taal. Afrikaans is gesien as die taal van die laer klasse van die samelewing, gewild in Pretoria en daarrond, maar nie geskik vir die meer gekultiveerde Afrikaners nie. Maar as dit gekom het by kommunikasie met, en mobilisering van, die wit Afrikaanssprekende werkersklas, was taal van absolute belang. ${ }^{41}$ Die term "Afrikaner" was vir'n tyd lank ook nie 'n linguistieke verwysing nie (daar was byvoorbeeld Hollands-georiënteerde Afrikaners), hoewel dit vir ander weer sentraal tot taal self en hulle identiteit was.

Die meeste vroeë Afrikaner-volksliedere (behalwe vir die een deur Van Rees) kom van 'n klein groepie Afrikaanse taalaktiviste van die Paarl in die tweede helfte van die 19de eeu. Een spesifieke volkslied wat belangrik was, was “'n Ieder Nasie”, ook bekend aan 'n hele aantal ander name soos "Die Afrikaanse Volsklied”, “Transvaalse Volkslied" en "Zuid-Afrikaanse Volkslied”" ${ }^{42}$ Die lirieke daarvan is gebaseer op 'n gedig van die Hollands-gebore onderwyser Arnoldus Pannevis, wat bygedra het tot vroeë pogings om Afrikaans as amptelike taal te laat erken. In 1872 het hy 'n pleidooi om die Bybel in Afrikaans te laat vertaal gepubliseer, wat gedien het as die inspirasie vir die stigting van die Genootskap vir Regte Afrikaners (GRA) in 1875, wat bekend geword het as die Eerste Taalbeweging. ${ }^{43}$ Die GRA het ook Die Afrikaanse Patriot - die eerste Afrikaanse koerant - in die Paarl gepubliseer en het steun gewerf vir Afrikanernasieskap en die aanvaarding van Afrikaans as geskrewe taal. ${ }^{44}$ Swanepoel skryf dat daar minstens drie ander komponiste was wat genoem word as skrywers van die woorde vir “"n Ieder Nasie” - S.J. du Toit, sy broer D.F. du Toit, en Pannevis se vertroueling, C.P. Hoogenhout. Al drie was stigterslede van die GRA. ${ }^{45}$ Hierdie vroeë taalpioniers was in opposisie met die Hollanssprekende elite wat neergesien het op

37 Ibid.

38 Bauer, The new catalogue of historical records, 1898-1908/09, p. 425.

39 Arnold Spoel, Vereenigd-Afrika. Lied en koraal voor eene zangstem en koor met piano- of orgelbegeleiding. Op. 18, ('s-Gravenhage : Van Eck, 1899).

40 Neerlandia 25. (Dordrecht: Geuze \& Co, 1921), beskikbaar by http://www.dbnl.org/tekst/_nee [besoek 16 Julie 2014].

41 Van Wyk, “Afrikaans Language, Literature and Identity”, p. 80.

42 A.M. Swanepoel, "Music inspired by the Afrikaner cause (1852-1902)", p. 66. Let op dat die oorspronklike spelling van hierdie titels verskil.

43 Ibid.

44 Die Afrikaanse Patriot, 1:1, 15 Januarie 1876, pp. 1-4.

45 A.M. Swanepoel, "Music inspired by the Afrikaner cause (1852-1902)”, p. 66. 
die Boere en gekant was teen die aanvaarding van Afrikaans as geskrewe taal. ${ }^{46}$ Die anneksering van die Transvaal deur die Britte in 1877 het sterk reaksie van die GRA ontlok. Nadat die Transvaal in 1880 sy onafhanklikheid teruggekry het, het Die Patriot 'n kompetisie begin om 'n nuwe volkslied te vind, blykbaar omdat hulle ontevrede was met die feit dat "Kent gij dat Volk" in Europa geskryf is deur iemand wat nie 'n Afrikaner was nie ${ }^{47}$ Ten spyte van geografiese afstand het die lede van GRA hulleself identifiseer as deel van dieselfde volk as die mense van die twee Boererepublieke wie se onafhanklikheid deur die Britte bedreig is.

'n Belangrike medewerker was Dominee J.S. de Villiers, wat verantwoordelik was vir die toonsetting van teks deur S.J. du Toit en wie self talle Afrikaanse psalms en gesange gekomponeer het. Hy kry erkenning vir een van die sewe verskillende melodieë wat geskryf is vir "'n Ieder Nasie", ${ }^{48}$ asook vir ander volksliedere soos "Vlaggelied" ${ }^{49}$ Nog 'n lied waaraan De Villiers en Du Toit saamgewerk het, is die "Transvaalse Vrijheidslied" van 1881, wat gewilder was onder Transvalers as Van Rees se amptelike volkslied. ${ }^{50}$ Van Rees se weergawe is ook soms die "Volkslied van de Zuid-Afrikaansche Republiek" genoem, maar verskil van die "Zuid-Afrikaansche Volsklied". ${ }^{1}$ Rautenbach noem nóg 'n "Transvaalsch Volkslied" wat nie "Kent gij dat Volk" (of " $n$ Ieder Nasie") is nie, en wat sy oorsprong het uit die Eerste Taalbeweging. ${ }^{52}$ Die lirieke toon openlike anti-Britse sentiment met strofes soos "In vry Transvaal, bevry van Britse dwingelandy", "Britse verraad", "Haal ons die Britse roofvlag neer". ${ }^{53}$ Hierdie lirieke was 'n duidelike verwysing na die eerste Anglo-Boereoorlog (1880-1881). De Villiers het "Die Vierkleur van die Transvaal" (ook bekend as die "Transvaalse Volkslied") in 1881 gekomponeer, en dit is ook nie dieselfde komposisie nie. ${ }^{54}$ Inteendeel, Swanepoel wys 27 komposisies uit wat gewedywer het om die volkslied van die Transvaal te wees. ${ }^{55}$ Hoewel die verskillende titels verwarring kan veroorsaak, het die feit dat die liedere almal gekomponeer is deur mense met noue bande met die GRA, die politieke belang daarvan onderstreep. ${ }^{56}$ 'n Aantal van hierdie liedere is later weer ingespan deur 'n nuwe golf van Afrikanernasionalisme toe hulle in 1937 in die FAK-sangbundel gepubliseer is.

Om terug te keer na die "Transvaalsch Volkslied" wat opgeneem is in Den Haag en Berlyn in 1900 (en die daaropvolgende jare) is dit onmoontlik om werklik te bepaal presies watter weergawes dit was, aangesien ons nie beskik oor die klank nie. Van Rees se weergawe is die mees waarskynlike, aangesien dit oorspronklik in Europa uitgereik is en daar soveel verskillende weergawes van die lied oor die jare hulle verskyning gemaak het. Hierdie vroeë opnames was

46 S. C. H. Rautenbach, "Die Kerksang as Agtergrond van die Poësie Uit die Eerste Tydperk", Tydskrif vir Volkskunde en Volkstaal III, 1946, p. 87.

47 A.M. Swanepoel, "Music inspired by the Afrikaner cause (1852-1902)", p. 27.

48 Ibid.

49 Die Afrikaanse Patriot, 1:1, 15 Januarie 1876, pp. 1-4.

50 Bouws, Die Huisgenoot, 22 November 1946, p. 106.

51 N. H. Theunissen, “Ons Volksliedjies”, Die Brandwag, 7 Oktober 1938, p. 17.

52 Rautenbach, “Die Kerksang as Agtergrond van die Poësie Uit die Eerste Tydperk”, pp. 87.

53 Ibid., pp. 86-87; ook N. H. Theunissen, Die Brandwag, 7 Oktober 1938, p. 17.

54 http://www.vetseun.co.za/anarkans/nav/toonsetverwerkkomposeer.html [besoek 6 Augustus 2014].

55 Swanepoel, pp. 101-140.

56 Vir 'n verdere bespreking oor die verband tussen nasionale volksliedere en politieke en militêre konflik, sien Lüdemann, “Buren-Marsch: Die Transvaalse volkslied in Duitse gewaad”, p. 58. 
ook nie in die strengste terme populêre musiek nie en dit is te betwyfel of hulle ooit te koop aangebied is in Suid-Afrika. En verder is dit moeilik om die politieke denkrigting van hierdie, meesal onbekende, Europese sangers te bepaal. Sommige van hulle het ook liedjies onverwant aan Suid-Afrika opgeneem en is daar geen bewyse buiten omstandigheidsgetuienis dat hul opnames van die Boere-volksliedere enigsins iets anders as bloot arbitrêr was nie. Dieselfde kan nie gesê word van die vroegste opgeneemde musiek in suiwer Afrikaans nie.

\section{Die eerste opnames in regte Afrikaans}

Volgens die SAME was die eerste Afrikaanse musiekopnames gemaak in Londen deur Paul Roos se Springbokrugbyspan tydens hul historiese eerste oorseese toer in 1906. Maar Kelly se katalogus in die CHARM-diskografie maak melding van ander, ouer Afrikaanse opnames wat in Londen gedoen is. ${ }^{57}$ Op 9 Julie 1906 (meer as twee maande voordat die Springbokke in Brittanje aangekom het), het 'n ene J.F. Smith "Transvaal Dialogue", "Transvaal Volkslied", “The Vine: Transvaal Recitation", "Boer melodies”, en “Transvaal Volks: Paraphrase” opgeneem. J.F. Smith was waarskynlik eintlik J.J. Smith - voorletters is dikwels verkeerd neergeskryf deur opname-ingenieurs of diskoloë wat later handgeskrewe dokumente moes ontsyfer. Ons weet dat J.J. Smith Afrikaanse monoloë in 1910 in Londen ${ }^{58}$ opgeneem het en dat sy voorletters by tye verkeerd as "J.D." aangegee is op opnamelyste. ${ }^{59}$ Anders as die Springbokke was sy opnames van 1906 nie kommersieël beskikbaar in Suid-Afrika nie (of ten minste nie aktief bemark nie), maar op 'n manier is dit dalk meer betekenisvol in die breër geskiedenis van die ontwikkeling van die taal om hom amptelik te erken as die eerste om grammofoonopnames in Afrikaans te maak.

J.J. Smith was 'n talentvolle linguis en 'n vroeë kenner van die Afrikaanse taal. Hy is in 1883 in die Tulbagh-distrik gebore en het skoolgegaan in die Paarl en Stellenbosch, waarna hy'n beurs gekry het vir sy nagraadse studies in Londen. ${ }^{60}$ Hy het in 1906 daar aangekom en hom vinnig aangesluit by ander jong Afrikaners, onder andere C. Louis Leipoldt, met wie hy'n hegte vriendskap gevorm het. Te oordeel na sy persoonlike briewe aan sy ma het hy nie die anti-imperialistiese politieke idees van baie Afrikaners van daardie era gedeel nie. Hy het eintlik die Engelse bo die Hollanders verkies en was eens 'n ondersteuner van Louis Botha. Dit het egter verander ná Uniewording, toe hy geswaai het na Hertzog. ${ }^{61}$ Smith het talle Afrikaanse dialoë opgeneem in Londen ná 1906 (en hierdie was wel kommersieël beskikbaar in Suid-Afrika onder die regte voorletters) en het met die Gramophone Record-platemaatskappy gekorrespondeer oor kopieregkwessies vir Afrikaanse opnames van Engelse gesange. ${ }^{62}$ Met sy terugkeer na Suid-Afrika het hy redakteur van Die Huisgenoot geword in 1916 en hy was die heel eerste professor in Afrikaans, aan die Universiteit Stellenbosch, in 1919, waar hy toevallig vir 'n jong Hendrik Verwoerd klasgegee het. Hy was ook die eerste redakteur van die Woordeboek vir die Afrikaanse Taal (WAT) ${ }^{63}$ en

57 Alan Kelly Catalogue, beskikbaar by http://charm.rhul.ac.uk/index.html [besoek 5 Oktober 2014].

58 Die Burger, 4 Mei 1974.

59 Alan Kelly Catalogue, http://charm.rhul.ac.uk/index.html [besoek 5 Oktober 2014].

60 Die Burger, 4 Mei 1974.

61 US Biblioteekargief, J.J. Smith Versameling, MS 333.K.F.1 (86), (88), (98).

62 US Biblioteekargief, J.J. Smith Versameling, MS 333.K.G. 14. Die brief verwys spesifiek na die Gezange opegneem deur Annie Visser.

63 J.D. Froneman, “H.F. Verwoerd's student years - cradle of his political career and thought”, Koers, 65:3, (2000), p. 401. 
was 'n belangrike figuur in die Tweede Taalbeweging, nes sy vriend Leipoldt. Hy het later 'n aantal opnames in Suid-Afrika gemaak (rondom 1930) wat gebruik is as leerhulpbronne vir Afrikaanse taalgebruik en grammatika, en het ook gekonsulteer oor die taalsuiwerheid van ander Afrikaanse opnames van daardie jare. Dit is fassinerend om na sy opnames van 1910 te luister omdat die aksent, taal en grammatika glad nie oudmodies klink nie.

'n Paar maande ná Smith se aanvanklike opnames het die Springbokke Springbok Chorus en War Cry in Londen opgeneem, en dit is uitgereik as deel van die Gramophone Concertplatemaatskappy plate-reeks. ${ }^{64}$ Hulle het ook "Springboks Conversing in the Taal", "Boer Recitation" en "Boer Dialogue" opgeneem. ${ }^{65}$ Opnames van gespoke Afrikaans en verwysings na die Taal het gewilde temas geword in latere opnames, wat aandui dat Afrikaans op daardie tydstip nog as 'n rariteit beskou is. Op Springbok Chorus and War Cry sing die rugbyspelers "My matras en jou kombers", "Die een kant op die ander kant af", "Al slaan my ma my neer" en "We are marching to Pretoria". ${ }^{66}$ Die matrikslys dui hierdie opnames aan as gedoen op 11 November $1906,{ }^{67}$ wat die dag was nadat die Springbokke Cambridge-universiteit met 29-0 geklop het. Die span was op die aand van die 11 de terug in Londen en moes nog pak voordat hulle vroeg die volgende oggend na Skotland vertrek het. ${ }^{68}$ As die datums korrek is, sal dit

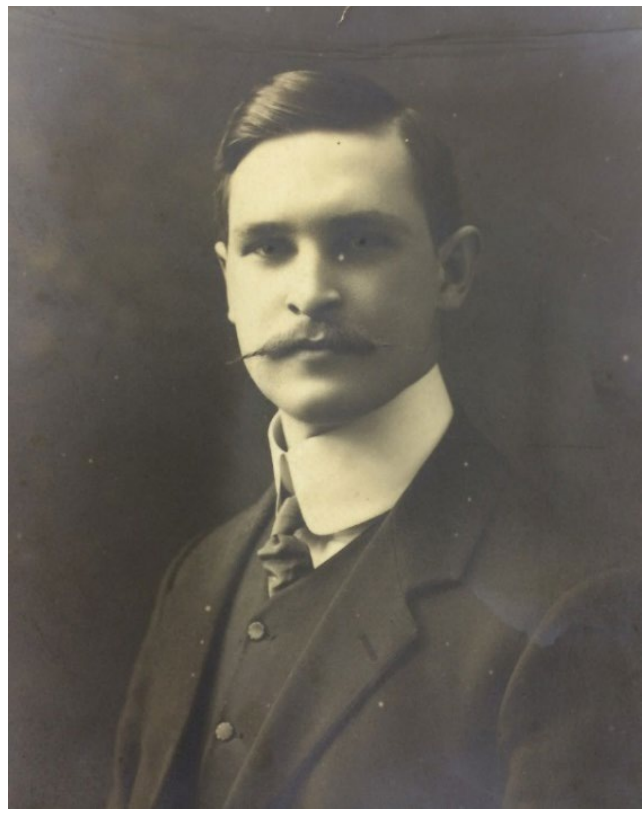

J.J. Smith as 'n jong man (J.J. Smith Versameling, Universiteit Stellenbosch argief Spesiale Versamelings) beteken dat die opnames waarskynlik sommer vinnig gedoen is laat in die aand. Die ateljee was nie te ver nie, by 31 Maiden-laan, loopafstand van die hotel. Ongelukkig word daar, vir'n relatief goed gedokumenteerde toer, geen melding gemaak van enige ateljee-opnames nie, waarskynlik omdat dit nie amptelik deel van die toer was nie en daarom nie as belangrik beskou is nie. Die liedjies is vier jaar later gebruik in wat waarskynlik die eerste advertensie vir Afrikaanse plate was, geplaas deur die Mackay Brothers-platemaatskappy ${ }^{69}$ in November $1910 .^{70}$

64 Malan (red.), Die Suid-Afrikaanse Musiek Ensiklopedie Vol. 1, p. 379.

65 Trewhela, Song Safari, p. 35; sien ook Malan (red.), Die Suid-Afrikaanse Musiek Ensiklopedie Vol. 1, p. 379.

66 A. Pakendorf, "Afrikaans music: History," http://myfundi.co.za/e/Afrikaans_music:_History [besoek 28 Augustus 2011]; sien ook Malan (red.), Die Suid-Afrikaanse Musiek Ensiklopedie Vol. 1, p. 350.

67 Alan Kelly Catalogue, http://charm.rhul.ac.uk/index.html [besoek 5 Oktober 2014].

68 L. Laubshcer en G. Nieman, The Carolin papers: a diary of the 1906/07 Springbok tour (Pretoria: Rugbyana Publishers, 1990).

69 Mackay Brothers was die plaaslike verspreider vir HMV en Zonophone en een van die eerste maatskappye wat plate in Suid-Afrika verkoop het.

70 Die Brandwag, 15 November 1910, p. ii. 


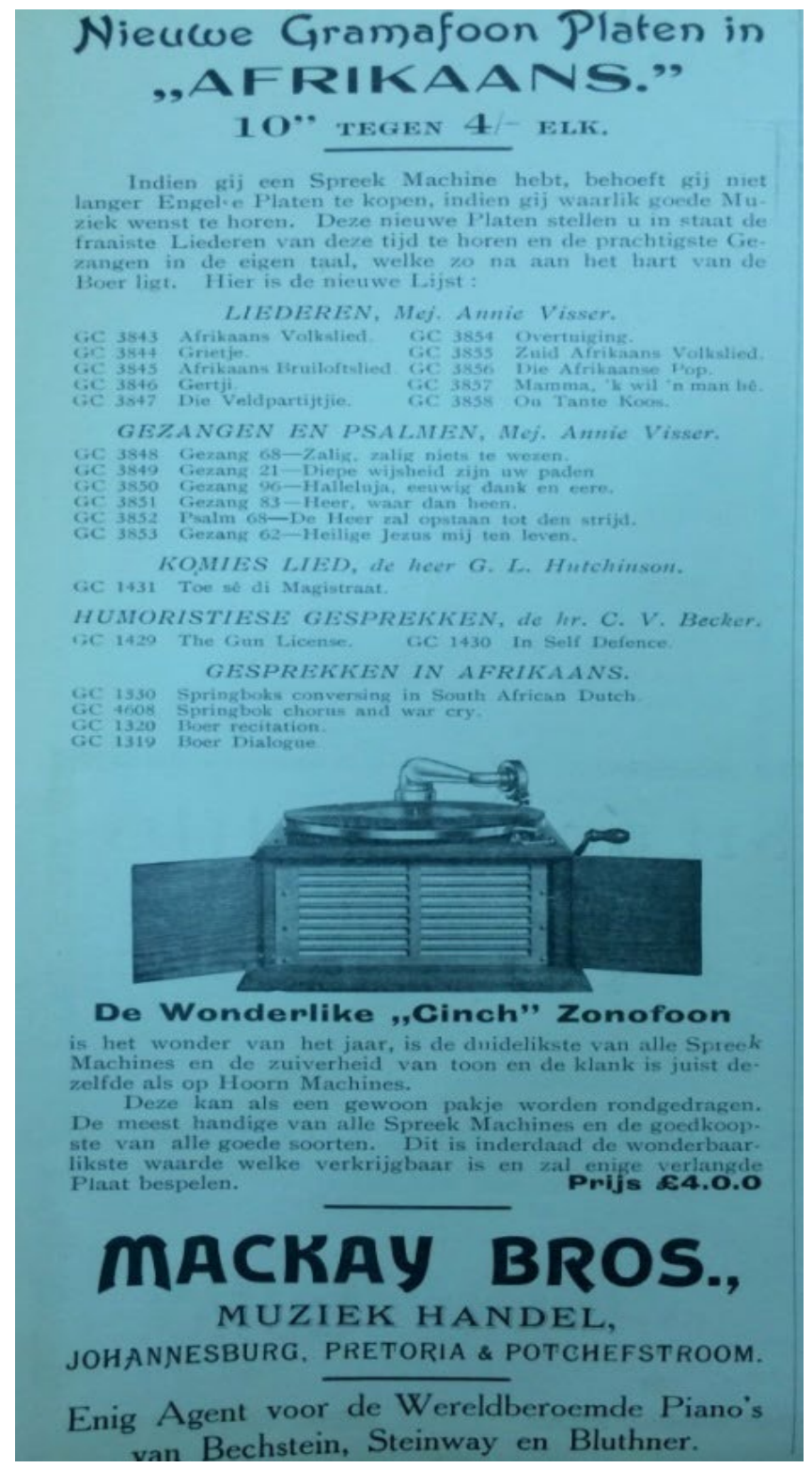

'n Vroeë advertensie vir Afrikaanse grammofoonplate, Die Brandwag, I5 November 1910.

Hierdie advertensie was vir 'n versameling van opnames wat in Londen gedoen is in die ateljees van die Gramophone Record-platemaatskappy van 1906-1910. Die Springbokke se opnames was die oudste daarvan. Twee dinge is belangrik hier: dit is nie bekend of die opnames gedoen is deur nèt die Afrikaanssprekende spelers of deur die hele span nie, in aggenome die spanning tussen Afrikaanse en Engelse spelers so kort ná die Anglo-Boereoorlog. Die ander is die voorkeur van Afrikaanse liedjies bo Engelses, moontlik weens die feit dat Afrikaans gesien is as 'n rariteit 
wat die moeite werd was om op te neem. 'n Britse maatskappy in Londen sou natuurlik reeds meer as genoeg Engelse materiaal hê wat gesing is deur mense wat beter daarvoor gekwalifeseer was as die Springbokke. Boonop was die onderskrif by die advertensie nogal onthullend:

Indien gij een Spreek Machine hebt, behoeft gij niet langer Engelse Platen te kopen, indien gij waarlik goede Muziek wenst te horen. Deze nieuwe Platen stellen $u$ in staat de fraaiste Liederen van deze tijd te horen en de prachtigste Gezangen in de eigen taal, welke zo na aan het hart van de Boer ligt. ${ }^{71}$

Die spanning tussen die Engelses en Afrikaanses wat hier uitgelig is, dui op die breër spanning tussen die twee groepe ses maande nadat die Unie van Suid-Afrika gestig is. Die term "Boer" is ook betekenisvol. Die bewoording in die advertensie (deur'n Engelse maatskappy) is nie toevallig nie. Die invloedryke linguis en stryder vir die Afrikaanse taal van die Tweede Taalbeweging, Gustav Preller, het gesê praktiese sakemanne behoort advertensies in die "Boeretaal" te plaas sodat hulle beter toegang tot die verbruikers kan kry. ${ }^{72}$

Die Brandwag is in 1910 deur die Afrikaanse Taalgenootskap gestig as 'n belangrike manier om die taal te mobiliseer tydens die stigting van die Unie. ${ }^{73}$ Isabel Hofmeyr se raak ontleding van die ontwikkeling van Afrikaanse literêre kultuur en die rol daarvan in die uitbreiding van die Afrikanernasionalistiese ideologie het die manier waarop publikasies soos Die Brandwag en Die Huisgenoot allerlei alledaagse dinge herverpak het as "Afrikaans" in fokus gebring. ${ }^{74}$ Advertensies soos die bogenoemde asook die plate wat adverteer is, was deel van hierdie proses van die definiëring van Afrikaner-identiteit en die "bou van 'n nasie uit woorde". ${ }^{55}$ Van die 23 liedere en dialoë is ses psalms en gesange, twee Afrikaner volksliedere (watter weergawes dit is, is onseker), agt populêre volksliedjies, drie humoristiese liedjies/dialoë (waarvan twee Engelse titels het) en vier is opnames van die Springbokke wat gesels en/of sing in "Suid-Afrikaanse Hollands". ${ }^{76}$ Die Gezangen was Afrikaanse weergawes van Engelse gesange en was nie oorspronklik nie. Die twee dialoë met Engelse titels deur Clarence Vivian Becker word gelys as "gesels in Afrikaans" en uitgereik op die B-kant van twee Afrikaanse dialoë wat deur J.J. Smith opgeneem is. ${ }^{77}$ Volgens Trewhela het Becker in 1908 opnames begin maak, ${ }^{78}$ hoewel die SAME se vroegste aangetekende datum 1910 is, wat ooreenstem met Kelly se katalogus. ${ }^{79}$ Becker was een van die Springbokkeurders van die 1906-toer, hoewel dit nie duidelik is of hy saam met die span in Brittanje was nie aangesien hy nie op spanfoto's van die toer verskyn nie. ${ }^{80}$ As hy wel deel van die toergroep was, was hy dalk teenwoordig by die opnamesessie in 1906 .

71 “As jy 'n grammofoonspeler het, sal jy nie meer Engelse plate hoef te koop as jy na goeie musiek wil luister nie. Hierdie nuwe plate sal jou in staat stel om na die mooiste liedjies en pragtigste gesange in jou eie taal te luister, wat so naby aan die hart van die Boer lê", vertaal deur Joey Kok.

72 G. Preller, 'Laa't Ons Toch Ernst Wezen', aangehaal in I. Hofmeyr, "Building a nation from words: Afrikaans language, literature and ethnic identity", p. 104.

73 Hofmeyr, "Building a nation from words", p. 106.

74 Ibid.

75 Ibid.

76 Die Brandwag, 15 November 1910.

77 US Biblioteekargief, J.J. Smith Versameling, MS 333. Pe.2 (7).

78 Trewhela, Song Safari, p. 35.

79 Malan (red.), Die Suid-Afrikaanse Musiek Ensiklopedie Vol. 1, p. 357.

80 L. Laubshcer en G. Nieman, The Carolin papers: a diary of the 1906/07 Springbok tour (Pretoria: Rugbyana Publishers, 1990). 

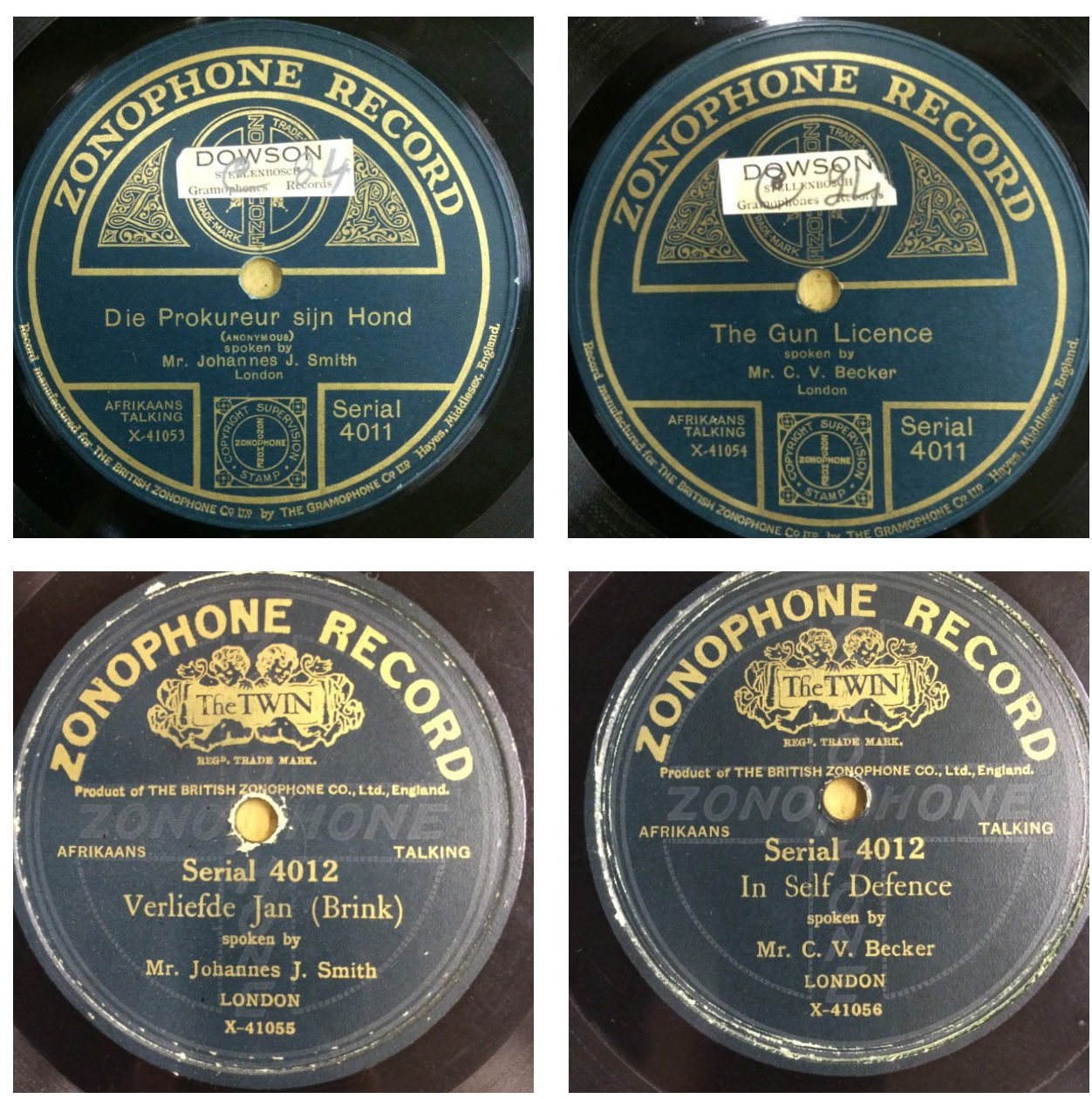

Vroeë Afrikaanse plate in Londen opgeneem, 1910 (uit die J.J. Smith Versameling).

Die sopraan Annie Visser het 'n prominente plek in die opnames. 'n Foto van haar het verskyn in De Goede Hoop in June 1914 met die onderskrif "Een bekwame vrijstaatse zangeres en een warm patriot". Omtrent 'n halfeeu later het haar patriotisme weer aandag gekry in Die Burger ${ }^{81} \mathrm{en}$ Die Huisgenoot. ${ }^{82}$ Albei artikels het Visser uitgebeeld as'n ware Afrikaner patriot, wat nie vreemd is as 'n mens die spesifieke politieke inklinasie van die publikasies in ag neem nie. Visser is gebore op die plaas Lokshoek in die Jagersfontein-distrik van die Vrystaat in 1876. Sy was die jongste dogter van Gert Petrus Visser, wat vir 19 jaar lank die voorsitter van die Volksraad was.Voor die Anglo-Boereoorlog het sy aan die Royal Academy of Music in Londen studeer, maar het na Amsterdam verhuis omdat sy "nie 'n gas kon wees'n land teen wie haar broeders geveg het nie". ${ }^{3}$ In 'n onderhoud met die Natal Mercury het sy gesê haar doel is om "Die Duchman trots te maak

81 F. Stegmann, "Annie Visser Het Eerste in Londen Opgetree”, Die Burger, 07 September 1961.

82 Stegmann, Die Huisgenoot, 15 Maart 1963, pp. 9, 61.

83 F. Stegmann, "Baanbreker van die Afrikaanse Lied", Die Huisgenoot, 15 Maart 1963, p. 61. 
op hulle taal deur daaroor en daarin te sing ... Die Dutchman moet so opgesweep word." ${ }^{84}$ Die artikels noem ook dat sy die "Zuid Afrikaans Volkslied" opgeneem het op die dag waarop die Unie van Suid-Afrika gestig is: 31 Mei 1910. Dit was moontlik 'n vorm van protes. Op publieke versoek oor inlgting oor haar lewe, het die destydse staatspresident C.R. Swart self in 'n brief reageer en daarin 'n aantal feite weergegee wat haar noue bande met die Afrikaner politieke elite van die vroeë twintigste eeu blootgelê het. Volgens hom het Visser 'n sterk verhouding met die Hertzogs gehad en was sy dikwels by hulle aan huis. Sy het ook gesing by die eerste kongres van Herzog se Nasionale Party in 1915 en die eer om die kleure vir die nuwe party (oranje en wit) te kies het haar te beurt geval. ${ }^{85}$ Hoewel Stegmann se beskrywing van Visser se patriotisme dateer uit die dae van absolute Afrikanernasionalistiese optimisme, is haar nou bande met die Afrikanernasionalisme van die eerste dekades van die twintigste eeu belangrik. Visser word selfs in die Suid-Afrikaanse Biografiese Woordeboek genoem, wat bevestig dat sy 'n heel prominente figuur was. ${ }^{86}$

'n Meer volledige bron van haar lewe is Bridging the Divide: The story of a Boer-British family, 'n boek deur Angela Read Lloyd, kleindogter van Lily Visser, Annie se suster ${ }^{87}$ Lloyd se goed-nagevorsde weergawe van meer as 'n eeu van twee families se geskiedenis (die Vissers en die Lloyds) gee in-diepte inigting oor Visser. Behalwe vir 'n paar interessante beuselagtighede, soos dat haar broer, Tom, Winston Churchill se hand behandel het nadat hy deur die Boere gewond en gevange geneem is, skets Lloyd 'n boeiende prentjie van Annie se loopbaan. Sy het haar debuut gemaak in 'n konsert in die Royal Albert Hall in Mei 1903, ${ }^{88}$ en haar solo-debuut was in die Aeolian Hall in Londen in 1904. Tydens die vertoning het sy in verskillende arias gesing, en ook African Romances van Samuel Coleridge Taylor, die befaamde komponis van Wes-Indiese afkoms, wat haar begelei het en wie sy as 'n persoonlike vriend beskou het. ${ }^{89}$ Read Lloyd gee ook konteks aan Visser se verhouding met Afrikaner-politiek. Op toer saam met die bekende pianis, Bosman di Ravelli in 1909 en weer in 1912, het sy al hoe meer Afrikaanse volksliedjies by haar repertoire ingesluit. Die bogenoemde aanhaling "om 'n Duchman trots op sy taal te maak" is eintlik gemaak in reaksie op die opskudding wat Hertzog in 1912 veroorsaak het met sy tweetalige opvoedingswetgewing vir die Oranje Vrystaat, en is voorafgegaan deur: "Ek is seker ... ek kan veel meer doen as Mnr. Hertzog - ek gaan dit vir hom sê ook". ${ }^{0}$ Sy het by die beweging om Afrikaans te bevorder betrokke geraak en vriende geword met die afgesette president van die Vrystaat, Marthinus Steyn, asook die skrywer C.J. Langenhoven. By Hertzog se toespraak by De Wildt op 7 Desember 1912 het Visser op 'n miershoop geklim en die Transvaalse Volkslied (die "Kent gij dat Volk"-weergawe) gesing in 'n vertoning van solidariteit. ${ }^{91}$ Soos wat haar loopbaan in die daaropvolgende jare getaan het, het sy haar al hoe meer toegespits op haar

84 J.P. Malan (red.), Die Suid-Afrikaanse Musiek Ensiklopedie Vol. 4 (Kaapstad: Oxford University Press, 1986), p. 457; sien ook I. Grové, “'Making the Dutchman proud of his language ...': 'n Honderd jaar van die Afrikaanse kunslied”, Tydskrif vir Geesteswetenskappe, 51:4, Desember 2011, p. 667.

85 Ibid.; sien ook Stegmann, Die Burger, 07 September 1961 en Malan (red.), Die Suid-Afrikaanse Musiek Ensiklopedie Vol. 4, pp. 456-457.

86 Vol. II, p. 838.

87 (Johannesburg: Jonathan Ball, 2002).

88 'n Prestasie wat baie min Afrikaners tot op hede kon regkry. Een is die sanger/kunstenaar Nataniël.

89 A. Read Lloyd: Bridging the Divide: The story of a Boer-British family, (Johannesburg: Jonathan Ball, 2002), p. 136.

90 Ibid., p. 151.

91 Ibid., p. 152. 
Boere-herkoms en het sy bekend geword as "Onse Vrystaatse sangeres". ${ }^{92}$ Sy het by die politiek betrokke gebly en gemeenskapswerk onder Afrikanerkinders gedoen tot met haar afsterwe weens borskanker in Augustus 1927.

Nog 'n skynbaar patriotiese Afrikaanse sanger was Joey Bosman wat, soos Visser, klassieke stemopleiding in Engeland ontvang het, moontlik gedurende die Anglo-Boereoorlog. Volgens 'n artikel in De Goede Hoop in 1903 het Bosman tydens haar drie-jaar-lange verblyf in Engeland eenkeer reageer op anti-Boere opmerkings deur doodkalm 'n lint met die Vierkleur (die vlag van die Zuid-Afrikaanse Republiek) aan haar bors vas te steek. ${ }^{93}$ Benewens die een artikel kon geen ander verwysings na Bosman gevind word nie en ook nie enige aanduiding of sy ooit enige musiek opgeneem het nie, aangesien sy na Suid-Afrika teruggekeer het lank voodat die eerste Afrikaanse opnames gemaak is. Aangesien Bosman haar nooiensvan was, kon sy moontlik later musiek onder 'n ander van opgeneem het. 'n Ene Joey Marais het "Danie en Lenie" en "Nader mijn God bij $U$ " in Londen in 1910 opgeneem, ${ }^{94}$ terwyl 'n Joey Stamrood 14 liedjies, waaronder "Zuid Afrika", in 1912 in Kaapstad opgeneem het. ${ }^{95}$ Dit is natuurlik spekulasie, maar Bosman moes ' $n$ prominente sanger gewees het om in 'n artikel in die gedrukte pers te verskyn. Die klassifisering van Bosman en Visser as patriotte herinner ons aan die manier waarop Die Brandwag en Die Huisgenoot Afrikaanse literêre figure opgehemel het in artikels en met volblad-foto's. ${ }^{96}$

Kate Opperman het "Het Volkslied van de Zuid-Afrikaanse Republiek", "Het lied der Afrikaners" en "Volkslied van de Oranje Vrystaat" in 1912 of 1913 in Londen opgeneem. ${ }^{97}$ Sy was oorspronklik van Ladybrand in die Vrystaat en het 'n beurs gewen om in 1911 Londen toe te gaan. Nes Annie Visser het sy

92 Ibid., p. 165.

93 De Goede Hoop, Julie 1903, p. 146.

94 Malan (red.), Die Suid-Afrikaanse Musiek Ensiklopedie Vol. 1, p. 374.

95 Ibid., p. 380.

96 Hofmeyr, "Building a nation from words: Afrikaans language, literature and ethnic identity", p. 109.

97 Malan (red.), Die Suid-Afrikaanse Musiek Ensiklopedie Vol. 1, p. 376.

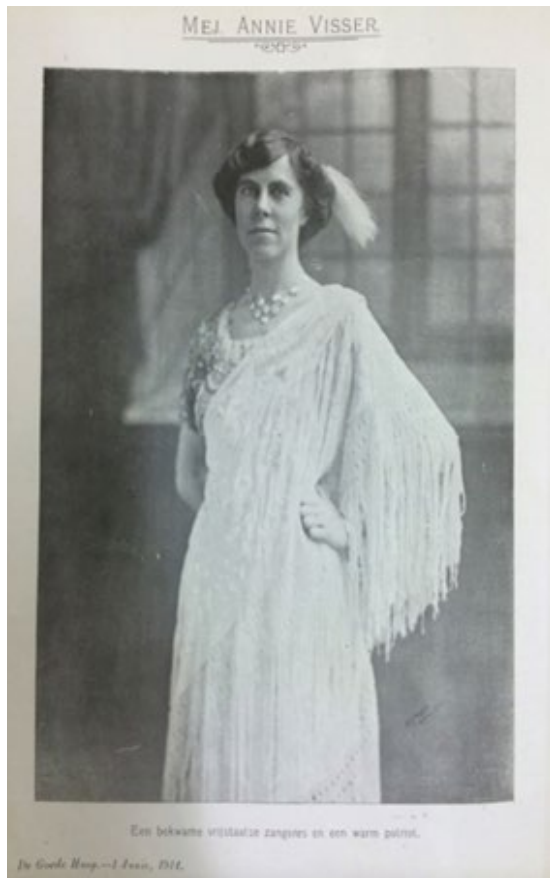

Annie Visser, "Een bekwame vrijstaatse zangeres en een warm patriot", De Goede Hoop, Junie 1914.

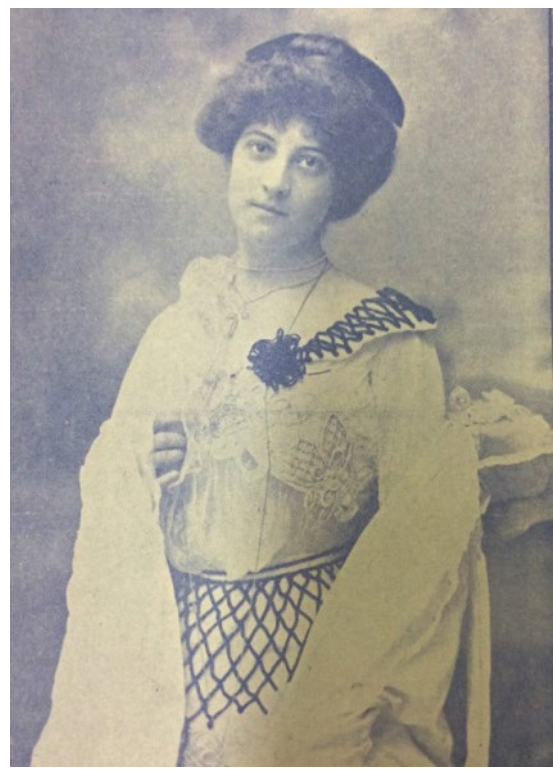

Joey Bosman - Patriotiese Afrikaanse sanger, De Goede Hoop, Julie 1903 
in die Albert Hall opgetree, en ook in die Queen's Hall en by Sondagkonserte in die Londen Palladium. ${ }^{98}$ Sy het in 1914 na Suid-Afrika teruggekeer en opgetree om geld vir die oorlogspoging in te samel en die troepe te vermaak. Jan Smuts het haar selfs genoem in 'n brief aan sy vrou oor moontlike private sanglesse vir een van sy dogters in $1921 .{ }^{99}$ Sy het in 1923 na Londen teruggekeer waar sy sanglesse gegee het, in operas opgetree het en op musiekklankbane gesing het (maar waarskynlik nooit in Afrikaans nie). ${ }^{100}$ Die SAME gee 'n gedetailleerde lys van verskeie ander vrouesangers wat opnames voor 1912 gemaak het, waaronder Ada Forrest se vroeë opname van "Hondt [sic] het fort", in 1907. ${ }^{101}$ Sy het ook "Die stor [sic] van Bethlehem" in 1908 opgeneem. Die meeste van Forrest se opnames was in Engels en dit is te betwyfel of sy enige openlike politieke oortuigings gehad het. Van

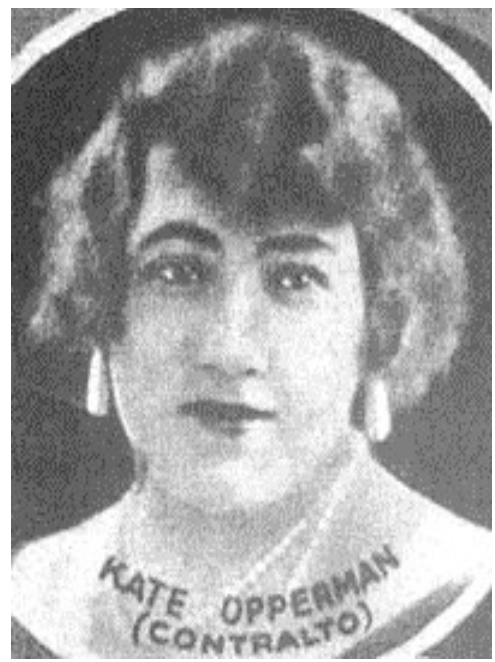

Kate Opperman. 1909-1913 het sy gereeld in Promenade-konserte in die Queen's Hall opgetree, maar nooit in Afrikaans nie. ${ }^{102}$ Een sanger wat wel in Afrikaans opgetree en Afrikaanse opnames gemaak het, was Floriel Florean. Sy het "Hul sal dit tog nie kry nie", "Overtuiging", "Ou tante Koos", "Grietjie", "Mamma, 'k wil 'n man hê" en "Toe sê de magistraat"103 opgeneem met 'n orkes in 1911. 'n Berig in die British Journal of Nursing het 'n konsert deur Florean in die prestigeryke Bechstein Hall geadverteer. Sy was glo bekend in Londen as die "Taalsanger", wat uitsluitlik opvoerings van Afrikaanse volksliedjies gedoen het. ${ }^{104}$ Interessant soos wat dit is, kon daar geen ander inligting oor haar gevind word nie, moontlik omdat sy nie dieselfde sosiale status as iemand soos Annie Visser gehad het nie. Interessant genoeg het sy die helfte van haar inkomste aan die sufrajette geskenk. ${ }^{105}$

Van al die vrouesangers staan Visser uit vir haar politieke standpunte waarvan daar gelukkig rekords is. Geen van die ander verskyn in versamelings van noemenswaardige Afrikaanse sangers nie. Die meeste van hulle is skynbaar oorsee opgelei waar hulle toegang tot opname-ateljees gehad het. Dit maak hulle relatief bevoorreg in terme van klas in vergelyking met ander wat nie dieselfe geleenthede gehad het nie. Benewens Visser was Floriel Florean 'n interessante figuur aangesien sy bekend was in Londen as iemand wat Afrikaanse volksliedjies gesing het. Dit was dalk die manifestatsie van 'n politieke identiteit, of eenvoudig net iets wat haar laat uitstaan het in Londense kringe. Ons weet nie. Die begeleiers vir hierdie Afrikaanse sangers was selde Suid-Afrikaans. Groepe buitelanders het ook Afrikaanse musiek opgeneem.

98 J. P. Malan (red.), Die Suid-Afrikaanse Musiek Ensiklopedie Vol. 3 (Kaapstad: Oxford University Press, 1986) pp. 353-356; sien ook http://saoperasingers.homestead.com/Kate_Opperman.html [besoek 28 November 2014].

99 J. van der Poel, Selections from the Smuts papers Vol. V (Cambridge: Cambridge University Press, 1973 ), p. 99.

100 J. van der Poel, Selections from the Smuts papers Vol. VII, (Cambridge: Cambridge University Press, 1973 ) p. 428.

101 Malan (red.), Die Suid-Afrikaanse Musiek Ensiklopedie, Vol. 1, p. 370.

102 www.Bbc.co.uk/proms/archive/performers/search/ada-forrest/1 [besoek 20 Oktober 2014].

103 Liedere se name is dikwels verskillend geskryf. In ander punlikasies is dit as volg geskryf: "Toe sê di magistraat"

104 The British Journal of Nursing, 11 Januarie 1913, p. 36.

105 Ibid. 
'n Vroeë voorbeeld is 'n Mackay Brothers-advertensie vir 'n Afrikaanse opname wat rondom 1910 gemaak is van die "Treurmarsch", 'n dodemars vir Paul Kruger op die musiek van die "Transvaalsche Volkslied" deur die Britse groep The Black Diamonds ${ }^{106}$ (hoewel hulle naam nie op die advertensie verskyn nie). ${ }^{107}$ Dit het twee sjielings en 'n sikspens gekos.

Swanepoel noem ander vroeë advertensies van werke wat ook opgedra is aan Afrikanerleiers soos "Valse Afrika", opgedra aan Generaal Hertzog, ${ }^{108}$ en "De Wet Marsch", opgedra aan Generaal De Wet wat uitgereik is as bladmusiek en nie as musiekopnames nie. ${ }^{109}$

Die Peerless Orkes se "Vat jou goed en trek Ferreira" en "Tikkiedraai - selections of popular Afrikaner songs and airs" van 1909-1910 was onder die eerste Afrikaanse musiekopnames. ${ }^{110} \mathrm{Al}$ hierdie opnames bevat 'n mengsel van Afrikaner nasionale volksliedere, gesange en geestelike liedere, Afrikaanse dialoog en gewilde, ligte liedjies. In Suid-Afrika

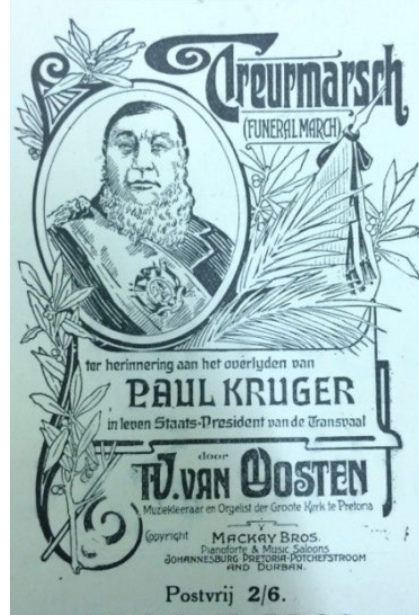
MACKAY BROS., Postbus 251, :: JOHANNESBURG.

Paul Kruger - Die eerste opgeneemde Afrikaanse stem? Die Brandwag,

15 Junie 1912. is informele populêre musiekopvoerings, veral van dansmusiek, meesal gedoen deur bruin musikante, ${ }^{111}$ maar dit is nie opgeneem nie. Bruin musikante het eenvoudig nie oorsee studeer nie en het dus nie toegang gehad tot opname-ateljees soos wat wit Afrikaanse sangers gehad het nie. En verder, as 'n mens die sensasie in ag neem wat die eerste grammofoonplate in Suid-Afrika veroorsaak het, waar hordes mense opgedaag het vir opname-konserte reg oor die land, ${ }^{112}$ was dit beslis 'n noemenswaardige ondervinding vir Afrikaners. Die nuwe tegnologie het luisteraars nie net verstom nie, maar om na Afrikaanse musiek te luister - soos die volkslied van die ou Transvaalse Republiek - wat gesing is deur simpatieke Europese sangers, of die Springbokke wat in Afrikaans sing terwyl die trauma van die oorlog nog rou was, moes sterk emosies aangewakker het. Pretorius noem dat Boere-kommando's af en toe in die veld vermaak is met musiekboksies wat by die Britte gesteel is of in verlate plaashuise gevind is (in een geval het hulle op 'n musiekboksie afgekom wat net drie Duitse liedjies gespeel het) ${ }^{113}$ hoewel dit onwaarskynlik is dat hulle ooit na Africana plate geluister het tydens die oorlog.

106 Malan (red.), Die Suid-Afrikaanse Musiek Ensiklopedie Vol. 1, p. 350.

107 Die Brandwag, 15 Junie 1912, p. iv.

108 Swanepoel, p. 482.

109 Swanepoel, p. 495.

110 Malan (red.), Die Suid-Afrikaanse Musiek Ensiklopedie Vol. 1, p. 377. Wat hierdie vroeë Londense opnames betref, verskaf die SAME gedetailleerde inskrywings wat nie hier herhaal hoef te word nie.

111 Vir 'n breedvoerige bespreking van rasse-identiteite in die ontwikkeling van populêre Afrikaanse musiek, sien Froneman, Pleasure Beyond the Call of Duty: Perspectives, Retrospectives and Speculations on Boeremusiek, pp. $49-76$.

112 Malan (red.), Die Suid-Afrikaanse Musiek Ensiklopedie Vol. 1, p. 354.

113 F. Pretorius, Life on commando during the Anglo-Boer War 1899-1902 (Kaapstad: Human \& Rousseau, 1999), p. 126. 


\section{Opnames in Suid-Afrika, 1912}

Die aantal Afrikaanse opnames het kwaai toegeneem ná 1912 toe die Gramophone Recordplatemaatskappy vir George Walter Dillnutt en sy mobiele opname-eenheid Suid-Afrika toe gestuur het om plaaslike opnames te maak. Dit was moontlik die eerste in sub-Sahara Afrika, en is uitgereik deur die filiaalmaatskappy Zonophone. ${ }^{114}$ Meer as 260 opnames is in Johannesburg en Kaapstad gemaak in Maart en April van daardie jaar, en die SAME noem minstens 126 Afrikaanse liedjies wat as albums uitgereik is. ${ }^{115}$ 'n Hele aantal daarvan was gewyde liedere. Die Het Moeder Kerk Koor van Kaapstad, gedirigeer deur C. Denholm Walker, het 28 gewyde liedere, meesal uit Engels vertaal, opgeneem, saam met 'n paar psalms en gesange. ${ }^{16}$ Daar was ook Afrikaanse stories, waaronder die digter Melt J. Brink se eie werke soos "Mijn land, mijn volk, en taal", en "Die vrome meid, deel 1/deel 2", asook "Afrikaans talking" was. ${ }^{117}$ Brink was 'n welbekende volksdigter en 'n produktiewe dramaturg bekend vir sy humoristiese stukke. ${ }^{118}$ Sanger P.J. du Toit het "N' dronkliedjie van 'n Mozambique" en "N' Jolly Hotnot" in Johannesburg opgeneem in $1912 .{ }^{119}$ Hierdie liedjies het 'n overte raskonnotasie: 'n "Mozambique" in hierdie konteks is 'n verwysing na 'n ingevoerde slaaf en "Hotnot" is 'n neerhalende term vir bruinmense. Die komediant Willem Versfeld was heel prominent en het minstens 26 opnames gemaak, waarvan die humoristiese liedjie "Sakobong Songki" een was. ${ }^{120}$ Hoewel die temas baie uiteenlopend in Afrikaanse volksliedjies se storievertellings was, was dit meesal humoristiese monoloë, asook "vuilpraatjies en rassistiese liedjies." ${ }^{121}$ Hulle getuig van die Afrikaner se weltanschauung op daardie tydstip. Dis ook belangrik om te noem dat daar baie min Afrikaner nasionale volksliedere onder hierdie opnames was.

Vanaf 1 November 1912, het Mackay Brothers ook hierdie plaaslik opgeneemde “Zonophone Double Discs" adverteer teen drie sjielings en 'n sikspens vir 'n 10-duim plaat en vyf sjielings vir 'n 12 duim. ${ }^{122}$ Twee ander advertensies vir Suid-Afrikaanse plate - een deur Columbia - Rena Records (teen 'n effens meer bekostigbare drie sjielings) en nog een deur sy plaaslike verteenwoordiger Polliack's, het kort daarna gevolg in die uitgawe van 15 December $1912 .{ }^{123}$ Al hierdie maatskappye en hulle plaaslike agentskappe was vir'n aantal jare betrokke in die plaaslike musiekbedryf, wat hulle baie invloedryk gemaak het tydens die vroeë jare van die Afrikaanse musiekbedryf. Hierdie voorbeelde van kulturele efemera is belangrik want hulle was gemik op 'n spesifieke Afrikanermark. Boonop is die kwessie van prys ter sake. Teen drie sjielings en 'n sikspens per plaat was hulle relatief duur. 'n Later advertensie vir Gallo se Singer-handelsmerk vir Afrikaaanse plate in 1930 wys dat hulle vier sjielings en 'n sikspens

114 L. Meintjies, Sound of Africa! Making music Zulu (Londen: Duke University Press, 2003), p. 275; sien ook http:// www.flatinternational.org/template_volume.php?volume_id=280 [besoek 12 Junie 2014].

115 Malan (red.), Die Suid-Afrikaanse Musiek Ensiklopedie Vol. 1, pp. 356-385.

116 Ibid., p. 375.

117 Ibid., pp. 360-361.

118 US Biblioteekargief, Melt J. Brink Versameling, MS 9.

119 Malan (red.), Die Suid-Afrikaanse Musiek Ensiklopedie, Vol. 1, p. 368.

$120 \mathrm{http} / /$ www.flatinternational.org/template_volume.php?volume_id=280 [besoek 12 Junie 2014].

121 Ibid.

122 Die Brandwag, 1 November 1912, p. xv; sien ook Trewhela, Song Safari, p. 44.

123 Die Brandwag, 15 Desember 1912, p. xiv and p. xcvii. 
gekos het, ${ }^{124}$ meer as die dagloon van drie sjielings en 'n sikspens wat in daardie tyd aan wit, ongeskoolde werkers betaal is. ${ }^{125}$ Dit is ongelukkig onmoontlik om te bepaal presies hoeveel Afrikaners grammofoonspelers besit het voor die Eerste Wêreldoorlog, hoewel die aantal Afrikaanse opnames en advertensies wys daar was 'n mark daarvoor.

'n Advertensie vir grammofoonplate in 1916 (baie van hulle is waarskynlik voor 1912 in Londen opgeneem) wys drie hooftemas: nasionalisme, volksliedjies en gewyde liedere. Verskeie nasionale volksliedere is opgeneem, soos "Vaderlands Liefde", "Unie Volkslied", "Zuid Afrikaanse Volkslied", "Oranje Vrijstaat Volkslied", “Transvaal Volkslied”, en "Afrikaner Volkslied”. Gewilde volksliedjies was onder meer "Mamma ik wil een man hê", "Ou Tante Koos" en "Grietjie". Hierdie opnames was noemenswaardig: aan die een kant het hulle gespeel op die nostalgie wat met die onafhanklikheid van die ou Vrystaat en Transvaalse Republiek gepaard gegaan het, en aan die ander kant het hulle aanklank gevind by 'n aparte politieke identiteit vir Afrikaners in die Unie. Dit is ook belangrik in die nadraai van die rebellie van 1914 toe baie Afrikaners wou gehad het die Unie moet onafhanklik van Brittanje word. Advertensies vir bladmusiek en opnames wat opgedra is aan Afrikaner-leiers soos Hertzog, De Wet en Kruger (wat toe al dood is) spreek ook van hulle

GRAMOFOON PLATEN

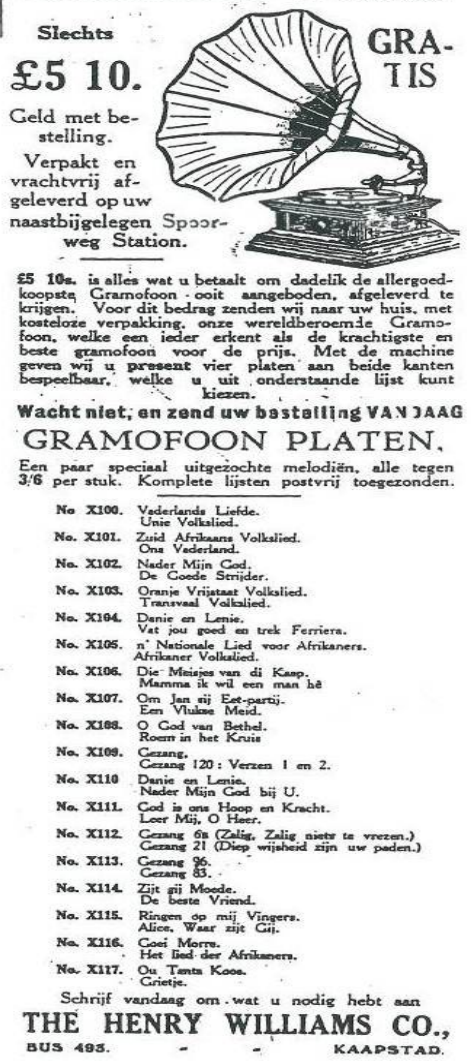

Afrikaner volksliedere, -liedjies en gewyde liedere, Die Huisgenoot, September 1916. plek as volkshelde. Behalwe vir 'n gevoel van nasieskap bevat hierdie veel groter klomp opnames (insluitende dié van die volgende dekades) kodes van rassedominasie, taalaspirasies, anti-imperialisme en godsdiens - al die temas wat later in die 1930's opgeroep is tydens die opkoms van 'n "meer akute" ${ }^{126}$ vorm van Afrikanernasionalisme.

Die ontwikkeling van die Suid-Afrikaanse musiekopnamebedryf is onderbreek deur die uitbreek van die Eerste Wêreldoorlog in 1914. Dit het te moeilik geraak om opnames Engeland toe te stuur om gedruk te word en dan die klaargemaakte produkte terug in Suid-Afrika te kry. Dit is eers in 1924 hervat toe die Edison-Bell Company 'n opnameateljee Kaapstad toe gestuur het waar 50 dubbelkant albums met nuwe akoestiese tegnologie opgeneem is. Van dié opnames was net 11 in Afrikaans en die meeste was van ligte operasang en kerkkore. ${ }^{127}$ In die volgende jaar was daar meer plaaslike opnames - steeds meesal in Engels - met die koms van elektroniese tegnologie. Die meeste van die nuwe opnames is gemaak vir die HMV-platemaatskappy. ${ }^{128}$ Die

124 Opskommel, 1992, Vol. 1, p. 16.

125 H. Giliomee, Die Afrikaners: Biography of a People (Kaapstad: Tafelberg, 2003), pp. 323-324.

126 P. Bonner, P. Delius \& D. Posel (reds.), Apartheid's Genesis, 1935-1962 (Johannesburg: Ravan Press, 1993$),$ p. 1.

127 Malan (red.), Die Suid-Afrikaanse Musiek Ensiklopedie, Vol. 1, pp. 361-385.

128 Ibid. 
materiaal was effens anders as die vroeëre opnames. Volksliedjies was baie minder prominent. Teen dié tyd het die Afrikaner se politieke landskap ingrypend verander, aangesien Hertzog se Nasionale Party in 1924 aan die bewind gekom het, en dit blyk dat die innige nasionalisme van die vorige eeu effens getaan het, al was dit net waar van die musiekopnamebedryf. Plaaslike opnames is op wasskywe gemaak en Londen toe gestuur, waar dit op gewone skellakskywe gedruk is. ${ }^{129}$ Die gehalte van hierdie mobiele opnames was swak, wat daartoe gelei het dat platemaatskappye in die 1920's en 1930's hulle kunstenaars Londen toe gestuur het om hulle musiek in beter ateljees op te neem. Aan die ander kant was plaaslike opnames goedkoper en kon dit vinniger uitgereik word. ${ }^{130}$ Tegnologiese vooruitgang in die opnameproses en die skywe self het 'n groot impak op die musiekbedryf gehad. 'n Ander element wat noodsaaklik was vir die verspreiding van popuêre musiek was (en is steeds) radio.

\section{Radio}

Die geskiedenis van radio-uitsendings in Suid-Afrika is baie meer deeglik opgeteken as die geskiedenis van populêre Afrikaanse musiekopnames (Eric Rosenthal, ${ }^{131}$ Ruth en Keyan Tomaselli en Johan Muller, ${ }^{132}$ en Peter Orlik ${ }^{133}$ is almal gesaghebbende bronne), hoewel die twee parallel geloop het. Diè geskiedenis hou nou verband met politieke gebeure, soos die oorlogstoestande wat die eerste twee jaar van die radio se ontstaan gedomineer het. In 1898 het die Veldtelegraaf-afdeling van die Transvaalse Staatsartillerie 'n radio-apparaat bestel by Siemens in Duitsland, maar dit het te laat arriveer om tydens die Anglo-Boereoorlog in gebruik te kon wees. Britse magte het nog toerusting wat op pad was na Paul Kruger in Kaapstad in November 1899, onderskep. ${ }^{134}$ Die plaaslike uitsaaiwese het amper 'n baie vroeë wegspring gehad in 1896 toe 'n jong Edward Jennings - wat vir die Poskantoor in Port Elizabeth gewerk het - suksesvol gëeksperimenteer het met radioseine wat gebaseer was op sy eie, onafhanklike navorsing. ${ }^{135}$ Die het hom een van die heel eerste uitsaaiers in die wêreld gemaak, maar ongelukkig vir hom het sy "unieke onderskeiding vir Suid-Afrika"136 nie steun van die staat gekry nie en was dit gevolglik byna heeltemal vergete. Die eerste wetgewing oor dié nuwe tegnologie van radio-uitsendings is in 1902 gepromulgeer toe die Kaapse Parlement die Wet op die Elektriese Telegraaf van 1861 aangepas het om "koordlose telegrafiestelsels" in te sluit. ${ }^{137}$ In die daaropvolgende jare het dié tegnologie meesal vir militêre gebruik ontwikkel, met spesifieke beperking op nie-militêre gebruik tydens die Eerste Wêreldoorlog.

\section{Ibid.}

130 Meintjies, Sound of Africa!, p. 275.

131 E. Rosenthal, You have been listening: The early history of Radio in South Africa (Kaapstad: Purnell, 1974).

132 R. Tomaselli, K. Tomaselli en J. Muller (reds.), Currents of Power: State Broadcasting in South Africa (Kaapstad: Anthropos, 1989).

133 P. B. Orlik, in S. W. Head (red.), Broadcasting in Africa: A Continental Survey of Radio and Television (Philadelphia: Temple University Press, 1974), pp. 140-146.

134 E. Rosenthal, You have been listening: The early history of Radio in South Africa (Kaapstad: Purnell, 1974), p. 7; sien ook P.B. Orlik, in S. Head (red.), Broadcasting in Africa: A Continental Survey of Radio and Television (Philadelphia: Temple University Press, 1974), p. 140.

135 Rosenthal, You have been listening, p. 4.

136 Ibid., p. 2.

137 Ibid., p. 8. 
Teen 1919 is hierdie beperkings op uitsendings tydens oorlogsituasies gelig, wat die weg gebaan het vir amateur radio-entoesiaste, of "hams" om te begin eksperimenteer met radio-uitsendings. John Samuel Streeter was moontlik die bekendste hiervoor, want hy was verantwoordelik vir Suid-Afrika se eerste gereelde weeklikse uitsendings van geselekteerde grammofoonopnames van musiekkonserte vanuit Kaapstad. ${ }^{138}$ Die eerste uitsending van 'n regstreekse optrede ('n strykorkes) is gedoen deur G.D. Walker in 1922 vanaf die eetkamer in sy huis in Uitenhage. ${ }^{139}$ Hoewel hierdie vroeë uitsaaiers nie veel meer as amateurs was nie, het radio al hoe meer gewild geraak, wat regulatoriese wetgewing genoodsaak het. Teen 1922 het dit 'n wetsvereiste geword vir amateur-radiosenders om 'n lisensie te hê. Streeter was die eerste om 'n lisensie te kry: nommer 1 (A1A). ${ }^{140}$ Sy uitsendings het geduur tot September 1924 en kon tot so ver as Pietersburg opgevang word. Hy het selfs die eerste radiokontak tussen Suid-Afrika en Amerika gemaak. Hierdie vroeë radioamateurs het eintlik buite die sfeer van Afrikaanse kultuur opgetree, want hulle was meesal Engelse middelklas stedelinge, maar hulle was tog pioniers in wat later 'n meer amptelike tegnologiese platform vir die massa-verspreiding van Afrikaanse kultuur sou word.

Die Suid-Afrikaanse Spoorweë het die eerste amptelike radio-uitsending op die aand van 18 Desember 1923 gedoen, wat gelei het tot die ontstaan van die eerste radiostasie op 29 Desember in Johannesburg. Die stasie is deur die Wetenskaplike en Tegniese Klub oorgeneem op 1 Julie 1924, en het daarna bekend gestaan as "JB". ${ }^{141}$ Die Cape and Peninsula Broadcasting Association het 'n soortgelyke diens in September 1924 in Kaapstad begin, gevolg deur die Durban Corporation op 10 Desember 1924. Hierdie drie radiostasies het hulle inkomste verdien uit lisensiëring, wat onvolhoubaar was. ${ }^{142}$ Gedurende die 1920's was plaaslike radio-uitsaaiwese meesal in Engels - vir verskeie redes - alhoewel regstreekse uitsendings van Afrikaanse musiekoptredes soms ingesluit is. Dit is onduidelik wanneer die eerste een plaasgevind het en wie die musikante was. Die mees waarskynlike kandidaat vir hierdie prestasie is Chris Blignaut. Blignaut het sy loopbaan gedurende die Eerste Wêreldoorlog afgeskop (toe geen oorsese kunstenaars Suid-Afrika kon besoek nie), toe hy 'n kontrak losgeslaan het om vir drie weke lank Engelse liedjies onder die skuilnaam 'Harold Wise' op te voer. ${ }^{143}$ Sommige bronne sê sy eerste radio-optrede (in Engels) was in 1923, ${ }^{144}$ wat baie vroeg was, aangesien amptelike uitsaaiwese eers op 18 Desember van daardie jaar ingestel is. 'n JB radioprogram van 22 Januarie 1926 wys dat hy in Engels gesing het, maar onder sy eie naam. ${ }^{145}$ Dit is onduidelik wanneer hy vir die eerste keer in Afrikaans begin uitsaai het, maar sy eerste plate is in 1929 vrygestel, en kort

$138 \mathrm{http} / / /$ www.saiee.org.za/content.php?pageID=260\#, p. 1 [besoek 20 Junie 2012].

139 Rosenthal, You have been listening, p. 2.

140 Ibid.

141 Ibid., p. 58.

142 P. Hopkins, Voëlvry - the Movement that Rocked South Africa (Kaapstad: Zebra Press, 2006), p. 38; sien ook http:// myfundi.co.za/a/Radio-uitsendings_in_Suid-Afrika [besoek 20 Junie 2012].

143 Beyers, C. J. (red.), Suid-Afrikaanse Bibliografiese Woordeboek Vol. V, (Pretoria: Raad vir Geesteswetenskaplike Navorsing, 1987), pp. 60-61.

144 P. Bester, Tradisionele Boeremusiek (Pretoria: Sigma Press, 1987), p. 78; sien ook Beyers, Suid-Afrikaanse Bibliografiese Woordeboek Vol. V, p. 61.

145 Trewhela, Song Safari, p. 37. 
daarna het hy begin speel in Afrikaanse kortfilms. Hy was die eerste Afrikaanse sanger om die sprong na dié medium te maak. ${ }^{146} \mathrm{Al}$ is presiese datums en inligting oor die vroeë dae van sy uitsaailoopbaan nie beskikbaar nie, was hy ongetwyfeld 'n groot figuur in vroeë Afrikaanse radio, rolprentwese en musiek. ${ }^{147}$

Taal was 'n besonder belangrike kwessie in die uitsaaibedryf. Engels het vroeë uitsendings oorheers, wat sommige Afrikaners ontstig het. Dit is vererger deur die feit dat Engelssprekendes in die stede gekonsentreer was (waar hulle die arm Afrikaners gedomineeer het) en goeie radio-ontvangs gehad het, terwyl die magsbasis van die Afrikaners in die plattelandse areas gebly het, waar ontvangs beperk was. ${ }^{148}$ Die klein groepie verstedelikte Afrikaners was meesal te arm om radio-ontvangers en lisensiefooie te bekostig. ${ }^{149}$ Op 1 April 1927 is al drie stasies gekombineer en is die African Broadcasting Corporation (ABC) sodoende gestig deur die Schlesinger Corporation, wat 'n vyf-jaar konsessie (wat later verleng is tot tien) ${ }^{150}$ van Hertzog se regering verkry het om alle uitsaaiwese in Suid-Afrika te beheer. Die ABC het 'n kommersiële Amerikaanse uitsaaiwesemodel nagevolg, ${ }^{151}$ wat beteken het dat die programmering hoofsaaklik bepaal is deur gewildheid en om gehoorgetalle te verhoog. Dit het beteken dat by verre die meerderheid luisteraars Engelssprekendes in stedelike gebiede was, wat gelei het daartoe dat die programme omtrent uitsluitlik in Engels was. Die 1920's was ook 'n belangrike historiese fase in Afrikaner politiek en die taalstryd, veral omdat Nederlands vervang is deur Afrikaans as een van die Unie se twee amptelike tale ná die Wet op Amptelike Tale van die Unie op 8 Mei 1925 aangekondig is. Die $\mathrm{ABC}$ se uitsendings het egter nie hierdie amptelike erkenning van Afrikaans weerspieël nie. Aangesien die ABC afhanklik was op lisensiefooie vir sy inkomste het dit sin gemaak, maar dit gee mens ook 'n interessante aanduiding van die geografiese verspreiding van Afrikaners en Engelssprekende witmense en is 'n sinspeling op sosiale klasverskille. Die swart bevolking het ook nie op dié stadium 'n noemenswaardige bron van inkomste vir die $A B C$ beteken nie. Beide die plate- en radio-bedryf sou kernfases van ontwikkeling in die volgende dekade betree.

146 Beyers, Suid-Afrikaanse Bibliografiese Woordeboek, Vol. V, p. 61.

147 Meer bibliografiese besonderhede oor Blignaut volg in Hoofstuk Twee.

148 G. Hayman \& R. Tomaselli, "Ideology and Technology in the Growth of South African Broadcasting, 1924-1971", in R. Tomaselli, K. Tomaselli \& J. Muller (reds.), Currents of Power: State Broadcasting in South Africa (Kaapstad: Anthropos, 1989), p. 29.

149 Ibid.

150 G. Roos, "Die Uitsaaiwese in Diens van ons Samelewing”, referaat gelewer by die FAK Buitengewone Volkskongres, 7 Augustus 1957, Stellenbosch, p. 2.

151 Hayman \& Tomaselli, "Ideology and Technology in the Growth of South African Broadcasting, 1924-1971", p. 29. 


\section{HOOFSTUK TWEE}

\section{"Plaaslike geur", spanning, en die opkoms van Afrikanernasionalisme}

\section{Populêre Afrikaanse musiek gedurende die 1930's}

Vroeg in 1930 het Columbia platemaatskappy van die VSA, advertensies in Suid-Afrikaanse koerante geplaas waarin hulle aangekondig het dat hulle van hulle eie opnametoerusting sou stuur met die spesifieke doel om musiek met plaaslike geur op te neem. ${ }^{1}$ Wat presies met "plaaslike geur" bedoel is, het kort daarna duidelik geraak toe Columbia se Suid-Afrika agent, H. Polliack \& Co., op 20 Maart 1930 die eerste plaaslike opnamekontrak geteken het met Chris Blignaut, die onbestrede ster van populêre Afrikaanse musiek uit hierdie era. ${ }^{2} \mathrm{Hulle}$ het deurgaans musiek wat in die buiteland opgeneem en in Engels gesing is, ingevoer en hier verkoop, maar die feit dat hulle die bykomende uitgawe aangegaan het om 'n opname-eenheid na Suid-Afrika te bring met 'n fokus op Afrikaanse musiek, spreek boekdele. Ook in die Columbia-stal was hulle filiaal Regal, wat goedkoop boeremusiekplate uitgereik het. ${ }^{3}$ Die uitreiking van hierdie plate was 'n suksesvolle strategie om die effek van die Groot Depressie teë te werk. Columbia se skuif het verskeie reaksies in die plaaslike opnamebedryf uitgelok, wat gelei het tot talle waardevolle opnames van vroeë populêre Afrikaanse musiek. Die Gallo Recordplatemaatskappy - die plaaslike agent vir Brunswick-Balke-Collender - ook van die VSA, moes 'n aansienlike bedrag leen om goedkoper plate te maak onder die Singer-handelsmerk (wat later na Gallotone verander is), ook spesifiek gerig op armer Afrikaners.

1 Opskommel 1, Augustus 1992, p. 13.

2 D.C. Pretorius, p. 21.

3 Opskommel 4, November 1990, p. 13. 
Die 1930's was liminale jare vir Afrikaners wat, as 'n groep, diep gedifferensieerde sosiale en kulturele netwerke getoon het, en die gewildheid van hierdie Regal- en Singer-boeremusiek albums het die heterogene elemente van klas en, tot 'n mate, politiese affiniteit onderstreep. Terwyl boeremusiek-opnames deur mense soos Faan Harris en Silver de Lange, of groepe soos Die Vyf Dagbrekers, Die Vier Transvalers, Die Vier Springbokke, en Die Ses Hartbrekers, geen ander eksplisiete doel gehad as lighartige vermaak nie, het dit deel uitgemaak van die populêre kultuur van die laer strata van die Afrikaner-samelewing, ${ }^{4}$ wat teen hierdie tyd 'n ernstige kommer vir die staat was. Dit word geillustreer deur die volgende stelling, die enigste verwysing na musikale aktiwiteite onder armblankes in die Carnegie-Kommissie se verslag van 1932:

Immediately (after receiving payment) they start living in luxury; instead of saving, they buy a number of things they do not need, such as a gramaphone or a piano. ${ }^{5}$

Die verslag het gewys arm wit families verdien meer in dorpe of met "delwery" as op plase, maar aangesien hulle nie ervare was daarin om met geld te werk nie, het hulle dit dikwels verkwis. Mense wat musiekinstrumente bespeel het of grammofone geluister het, is geassosieer met die "spandabelrige, sorgvrye lewe" van armblankes wat oorgespandeer het in die vet jare en afhanklik was van welsyn in die maer jare. ${ }^{6}$ Die gelukkiger mans het werk gevind as "[s]kaapwagters, bosbouers en houtkappers, 'bywoners', spoorwegwerkers, algemene arbeiders, ongeskoolde fabriekswerkers, 'transportryers', delwers."7 Saam met ander sosiale kwale soos misdaad, werkloosheid en 'n tekort aan opvoeding, het dit getuig van onrusbarend baie armblankes se wanaanpassing aan ekonomiese agteruitgang van die tyd. Etlike historiese faktore het gelei tot die geleidelike finansiële agteruitgang van vele Afrikaners teen die vroeë 1930's. Die praktyk om die familieplaas te verdeel en by afsterwe die lappe grond aan oorlewende kinders (of ten minste die seuns) na te laat het, teen die vroeë 20ste eeu, dikwels gelei tot die fragmentasie van lewensvatbare landbougrond. Eienaars van die kleiner, ekonomies onvolhoubare eenhede het vinnig verkoop en stad toe getrek of bywoners geword op iemand anders se grond. Dit is vererger deur die Groot Depressie van die vroeë 1930's, wat 'n daling in kommoditeitspryse tot gevolg gehad het wat plattelandse Afrikaner-produsente geraak het, terwyl klein besighede, fabrieke, myne en winkels toegemaak het. Bowendien het 'n ernstige droogte in 1932-1933 dit nog moeiliker gemaak vir boere om te oorleef. Die ekonomiese agteruitgang het ook politieke gevolge gehad. Teen vroeg 1933 het die gewildheid van Eerste Minister Hertzog se Nasionale Party (NP) tot so 'n mate gekwyn dat hy dit ernstig oorweeg het om met sy teenstander, Jan Smuts, se Suid-Afrikaanse Party saam te smelt. Dit het in 1934 'n realiteit geword en het 'n herrie onder meer onversetlike Afrikanernasionaliste ontketen wat gelei het tot die stigting van die wegbreek Gesuiwerde Nasionale Party onder D.F. Malan.

Die Carnegie-kommissie was die eerste grootskaalse wetenskaplike poging om die omstandighede te analiseer van armblankes - 'n sosiale kwaal wat tot 1932, toe die bevindinge gepubliseer is, toegeskryf is aan 'n soort ingebore morele gebrek. Die verslag het lig gewerp op die gevolge van verstedeliking, ontworteling, lae vlakke van onderrig ensovoorts, en het die kwessie van wit

\footnotetext{
4 Froneman, p. 29.

5 J.R. Albertyn, The Poor White Problem in South Africa: Report of the Carnegie Commission (Stellenbosch: Pro Ecclesia, 1932), p. 42.

6 Ibid.

7 Albertyn, The Poor White Problem in South Africa: Report of the Carnegie Commission, p. vii.
} 
armoede na die kern van die politieke gesprek gedwing. Die realiteit van honderde duisende armblankes wat in haglikheid in stedelike sentrums geleef en vrylik gemeng het met ander rasse, het beduidende politieke gevolge ingehou en gelei tot talle pogins om diegene wat die gevaar loop om oor die rasselyn te glip, op te hef. Vir sommige het dit ook die opheffing van musieksmaak beteken. 'n Voorbeeld kan gevind word in 'n verslag van die voorsitter van die FAK, Dr N.J. van der Merwe, by die FAK Kultuurkongres van 1931:

Toe die Colombia platemaatskappy indertyd sy plan te kenne gegee het om Afrikaanse opnames te maak, het die F.A.K. gevoel dat die smaak van die ontwikkelde Afrikaner so min moontlik deur lawwighede gekwets moet word. Ons het die firma van ons ondersteuning verseker mits hulle plate van hoogstaande gehalte op die mark sou bring. Dog besigheid en sentiment gaan meesal nie hand aan hand nie en moes ons in 'n latere skrywe protes aanteken teen die propagering van sulke liedjies as "Brandewyn laat my staan" en "Hou jou roksak toe." Dames en here, ons kan hierdie minderwaardige plate alleen teëwerk deur opnames van hoër kunswaarde te koop en die voordraers van Brandewyn- en roksakliedjies nie 'n persoonlike geleentheid te gee om voor ons op te tree nie. ${ }^{8}$

"Hou jou roksak toe" is opgeneem deur Joe Snyman, met "Die Aap se Bruilof" op die B-kant.9 Joe Snyman het ook opgeneem met Boy Solomon en Die Voortrekker Danskwartet, een van die eerste boeremusiekgroepe om vir Columbia op te neem, naas Die Vyf Vastrappers. ${ }^{10}$ Soos die getal stedelike Afrikaners begin groei het gedurende die 1930's, het "organisasie-Afrikaners", ${ }_{11}$ soos die FAK, Afrikaners geleidelik begin mobiliseer as'n groep onder die beskerming van Afrikaner etniese nasionalisme. Dit is egter betwyfelbaar of hulle enige invloed oor platemaatskappye in 1931 gehad het, want die organisasie was toe slegs twee jaar oud.

Een van die FAK se eerste take was om in 1931 opdrag te gee vir 'n Afrikaanse Volkssangbundel. Die eerste persoon wat genader is om die projek te bestuur was Stephen Eyssen. Eyssen was 'n musikant wat opgelei is in klassieke musiek. Hy was eens 'n student van C. Denholm Walker, wat op sy beurt die Moederkerk koor dirigeer het vir die 1912 plaaslike Afrikaanse opnames in Kaapstad (sien Hoofstuk Een). Hy het 'n aktiewe figuur in die FAK en later ook die SAUK (Suid-Afrikaanse Uitsaaikorporasie) gebly. Na 'n paar jaar se stadige vordering het die sendeling/ onderwyser/komponis Hugo Gutsche (wat die hoofredakteur van die bundel geword het) en die bekende Afrikaanse digter W.J. du P. Erlank (ook bekend as Eitemal) by hom aangesluit in 1934 . Hulle het daarin geslaag om die eerste publikasie saam te stel in 1937. Hoewel dit nie die eerste versameling van Afrikaanse liedjies was nie, was dit op daardie stadium die grootste (314 liedjies). Dit was 'n versameling Afrikaanse volks- en liturgiese liedjies en nasionale volksliedere wat as volksvriendelik en 'n aanvaarbare deel van die ontwikkelende Afrikanernasionalistiese kulturele erfenis geag is. Dit het liedjies uitgesluit wat die FAK as volksvreemd beskou het. Dit is ironies dat 'n aantal van die liedjies wat in die Volksangbundel ingesluit is bestaande melodieë uit die buiteland was met Afrikaanse lirieke, en dus nie so uniek aan Afrikanerkultuur was as wat voorgegee is nie. Benewens die Volksangbundel het die FAK, in vennootskap met HMV, opdrag

\footnotetext{
8 "Verslag van FAK Kultuurgkongres", Handhaaf en Bou 4 (21-23 Des 1931), p. 7

9 Bester, Tradisionele Boeremusiek, p. 47.

10 Froneman, p. 29.

11 Giliomee, Die Afrikaners, pp. 400-402.
} 
gegee vir die opname van sewe Afrikaanse plate in Johannesburg in 1930 of 1931. Hierdie was meer 'ernstige' plate, en het liedjies ingesluit wat gesing is deur klassiek-opgeleide sangers soos Nunez Holtzhausen, Anna Steyn en Eyssen self. Die sangers is begelei deur die orkes van die ABC (African Broadcasting Company). ${ }^{12}$

Terwyl die FAK per brief op Columbia se aankondiging van hulle opname planne gereageer het, het Gallo op hulle beurt inderhaas van hulle kunstenaars Londen toe gestuur om plate te gaan opneem by die Metropole Record Company. ${ }^{13}$ Hier het Lou Davidson, Tredoux Odendaal en Gerald Steyn meer as vyftig Afrikaanse meesters opgeneem met die hulp van opname-ingenieur John Hecht. Hecht het later Suid-Afrika toe getrek, en in 1936 die land se eerste grammofoondrukpers opgerig vir Gallo. Sodoende het hy onwetend die oorlewing en groei van die plaaslike musiek-opname bedryf verseker tydens die Tweede Wêreldoorlog, toe dit onmoontlik geraak het om meesters oorsee te stuur om gedruk te word..$^{14}$ Die musiek wat Davidson, Odendaal en Steyn gedurende hierdie sessies in Londen opgeneem het, het gewissel van polkas, walse, vastrap en sentimentele liedjies tot 'n paar gospel-nommers. Die gebruik van instrumente was ook innoverend, want vir die eerste keer kon die konsertina, viool, ukulele, banjo en mandolien op Afrikaanse plate gehoor word. ${ }^{15}$ Hierdie instrumente, veral die konsertina, het sinoniem geraak met die populêre Afrikaanse musiek van die tyd. Engelse treffers is ook na Afrikaans vertaal en heropgeneem, soos "Klein Maat", wat 'n goedgekeurde vertaling was van $\mathrm{Al}$ Jolson se treffer "Little Pal". ${ }^{16}$ Hierdie drie kunstenaars was onder druk om soveel materiaal as moontlik op te neem in 'n kort tyd (om te verseker dat Gallo hulle musiek kon vrystel voor Columbia). Dit verduidelik die ateljee-dinamika en leen van liedjies wat nie uit Suid-Afrika afkomstig was nie. Wanneer daar 'n tekort aan liedjies was en druk om albums vry te stel, het platemaatskappye dikwels pragmaties te werk gegaan om materiaal te vind. Hierdie strategie sou 'n gereelde eienskap van die Suid-Afrikaanse opnamebedryf word, insluitende die Afrikaanse sektor, en sou later daartoe lei dat vele Schlager-treffers se raklewe verleng word as verwerkte Afrikaanse liedjies.

Gallo het daarin geslaag om hulle plate vry te stel net vier dae voor Columbia se opname-eenheid in Kaapstad geland het in Mei 1930. ${ }^{17}$ Kort voor lank het hulle meer musikante, insluitende 'n groep swart kunstenaars, gestuur om in Londen te gaan opneem. ${ }^{18}$ Dit kom voor asof twee van die Afrikaanse musikante wat saam met die tweede groep uitgestuur is, slegs bekend as Coetzer and Meyer, die swart sangers in Julie 1930 begelei het. ${ }^{19}$ Op 'n ander opname uit 1930 wat by dieselfde ateljee gemaak is deur Griffiths Motsieloa en Ignatius Monare is die Hawaiiese kitare waarskynlik gespeel deur Pieter Burger en Jan van Dyl. ${ }^{20}$ Hierdie twee voorbeelde van

12 Malan (red.), Die Suid-Afrikaanse Musiek Ensiklopedie Vol. 1, p. 352.

13 Ibid.

14 J.P. Malan, (red.), Die Suid-Afrikaanse Musiek Ensiklopedie Vol. 1, p. 351.

15 Allingham, Opskommel 1, 1992, p. 13.

16 Ibid., p. 14.

17 Ibid., p. 13.

18 Gallo sou van vroeg af al plaaslike swart musiek vrystel en een van die belangrikste rolspelers in die opname van swart kunstenaars se musiek bly.

19 Allingham, Opskommel 1, 1992, p. 17.

20 R. Allingham, aangehaal in C. Ballantine, Marabi Nights, Jazz, 'race' and society in early apartheid South Africa (Scotsville: University of KwaZulu-Natal Press, 3de Uitgawe, 2012), p. 218. 
veelrassige samewerking was uitsonderings. Ten spyte van die gewildheid van hierdie vroeë opnames het die kommersiële Afrikaanse musiekmark regtig eers momentum begin optel in Johannesburg in 1932, ${ }^{21}$ toe Gallo die eerste opname-ateljee in sub-Sahara Afrika gebou het en begin het om die eerste plaaslike meesters te maak. ${ }^{22}$ Vanweë die geraas van die verkeer het die ateljee geskuif na 'n nuwe adres by Markstraat 150 in 1933. In 1938 het dit geskuif na die sesde vloer van 'n gebou op die hoek van Troye- en Presidentstraat, waar dit gebly het vir die volgende drie dekades. ${ }^{23}$

\section{Bekende Afrikaanse musiekkunstenaars van die 1930's}

Terwyl Gallo sy kunstenaars Londen toe gestuur het in 1930, het Chris Blignaut sy hoogs suksesvolle opname-loopbaan afgeskop. Net in die eerste vier maande van 1931 het hy byna 55000 albums vir Columbia verkoop. ${ }^{24}$ In bykans twintig jaar (tussen 1930 en 1949) het hy omtrent 240 liedjies opgeneem vir 'n klomp verskillende platemaatskappye en meer as twee miljoen plate verkoop. ${ }^{25} \mathrm{Hy}$ was ook eerste om die een miljoen kerf te bereik met sy plateverkope. Vanweë die sukses van kommersiële Afrikaanse musiek het musikante'n pragmatiese benadering gehad in terme van hulle skuilname. Dit is ironies dat terwyl Chris Blignaut op die radio begin sing het as Harold Wise, ${ }^{26}$ daar 'n aantal Engelse musikante was wat húlle name verander het om Afrikaans te klink:

So he introduced me on the piano, Les Kelly on bass, Billy Wright on guitar and so on. Only three of us were Afrikaans: Susan, Sam Petzer and myself. So we changed the names of the others so the listerners wouldn't say, "Oh, this is just a lot of Rooinekke playing." Les Kelly, for instance, became Les Meintjies, and so on. Chris Lessing was the vocalist. Sam Petzer was on piano accordion. He used to waggle the concertina as well, so as to satisfy the traditionalists. ${ }^{27}$

Blignaut het ook as 'n talentsoeker opgetree. Talle van die boereorkeste van die Johannesburg omgewing wat van die vroegste albums opgeneem het, is eers deur Blignaut genader. Omdat hy onvertroud was met die boeremusiek-toneel het hy 'n jong musikant, Gerrie Snyman, gevra om hom te help om verskillende groepe te vind vir opnamesessies. Hierdie groepe het Die Vier Springbokke, ${ }^{28}$ Die Vier Transvalers, ${ }^{29}$ en Die Vyf Dagbrekers ${ }^{30}$ ingesluit. Blignaut was ook verantwoordelik om name te gee vir 'n klomp van hulle want hulle het nie name

21 Meintjies, Sounds of Africa!, p. 276.

22 R. Allingham, "South Africa - Popular Music: Nation of Voice”, in S. Broughton, M. Ellingham, \& R. Trillo (reds.), World Music: The Rough Guide. Africa, Europe and the Middle East Vol. 1 (Londen: Rough Guides, 1999), p. 639.

23 Meintjies, Sounds of Africa!, p. 276.

24 D.C. Pretorius, Musieksterre van gister en vandag: Lewensketse En Foto's Van Meer as 100 Musieksterre (Pretoria: JP \& Son van der Walt, 1998), p. 22.

25 Ibid.

26 Volgens Piet Bester was sy eerste radio-optrede die liedjie "O’Ruddier and the Cherry", waarna hy gevra is om plate te maak. Hy het daarmee begin in 1930, hierdie keer onder sy regte naam; sien Bester, Tradisionele Boeremusiek, p. 78.

27 R. Trewhela, Song Safari (Johannesburg: Limelight Press, 1980), p. 50.

28 Bester, Tradisionele Boeremusiek, p. 23.

29 Ibid., p. 26.

30 Ibid., p. 33. 
gehad nie. ${ }^{31}$ Gerrie Snyman het sy eie uitvoerende loopbaan begin by die Labour Party Club in Johannesburg. ${ }^{32}$ Dit is egter onduidelik of dit polities gemotiveerd was. Baie van hierdie musikante was myners wat van Oos-Randse myndorpe afgekom het, of transportryers wat nie enige formele musiekopleiding gehad het nie. Die feit dat Blignaut verwyder is van die boereorkeste in sy geboortedorp, Johannesburg, sinspeel op klasse-onderskeid. As 'n suksesvolle verskeringsmakelaar dwarsdeur sy musiekloopbaan, ${ }^{33}$ was hy'n middelklas Afrikaner.

Blignaut se politiek, soos dié van baie ander suksesvolle Afrikaanse kunstenaars, was waarskynlik meer pragmaties as ideologies. Hy kon politieke spanninge tussen Afrikaner-faksies satiriseer ten koste van beide kante, soos gehoor kan word op sy liedjie "NAT en SAP". ${ }^{34}$ Sulke satire was aanvaarbaar as dit aangebied is op 'n sekere onpartydige manier, selfs op tye wat die politieke spanning hoog geloop het. Hy sou ook sy repertoire aanpas na gelang van hoe konserwatief die gehoor was:

He had one or two mildly naughty songs and, if he spotted too many stern faces before him, he'd give me the cue and out they'd go. ${ }^{35}$

Trewhela se beskrywing van sy toere saam met Blignaut is 'n belangrike bron. Hy noem dat konsertkaartjies in die platteland twee sjielings en 'n sikspens gekos het en alhoewel dit laag mag voorkom, kon gehore nie meer bekostig nie. ${ }^{36}$ Ten spyte van sy sukses, is geen van sy treffers ingesluit in die eerste FAK Volksangbundel van 1937 nie. Ander gewilde Afrikaanse opname-kunstenaars het kwaaier teenstand van die kulturele elite in die gesig gestaar, veral David de Lange.

David de Lange was 'n singende myner wat uiters gewild was onder die groeiende Afrikaner werkersklas. $^{37}$ 'n Groot gedeelte van sy musiek is vrygestel onder die goedkoper Singer-handelsmerk en later onder Gallotone. Hy was die eerste kunstenaar om die ou praktyk van sang saam met tradisionele boeremusiek - algemeen by danse waar die genre van musiek gespeel is - op plaat vas te lê. ${ }^{38}$ Sy musikale styl was nie beperk tot hierdie genre nie. Volgens Froneman was daar sterk ooreenkomste tussen van sy musiek en Amerikaanse vaudeville, en baie van sy liedjies was direkte vertalings van gewilde Amerikaanse deuntjies. ${ }^{39}$ Gedurende die Tweede Wêreldoorlog het hy ook baie gewilde Engelse oorlogstreffers na Afrikaans vertaal. ${ }^{40}$ As mens dit in ag neem was De Lange 'n veelsydige vermaaklikheidskunstenaar en nie beperk tot boeremusiek nie. De Lange se bekendheid het al gekwyn voor sy dood in 1947, en hy word vandag as 'n raaiselagtige randfiguuur voorgehou. Benewens sporadiese hervrystellings van sy

31 Bester, Tradisionele Boeremusiek, pp. 38-39.

32 Ibid., p. 38.

33 Trewhela, Song Safari, p. 38.

34 Ibid., p. 78.

35 Ibid., p. 38.

36 Ibid., p. 39.

37 http://www.boeremusiek.org/orkesteenkarakters.html\#DawidDeLange [besoek 23 Augustus 2012].

38 Ibid., sien ook D.C. Pretorius, Musieksterre van gister en vandag: Lewensketse En Foto's Van Meer as 100 Musieksterre (Pretoria: JP \& Son van der Walt, 1998), p. 61.

39 W. Froneman, "Seks, Ras en Boeremusiek: agter die retoriek van gebrekkige sanglus by die 1938-Voortrekkereeufees", Litnet Akademies, 11:2 (2014), p. 428.

40 Pretorius, Musieksterre van gister en vandag, p. 60. 
musiek, is hy ook later herdenk in sanger Randall Wicomb se trefferliedjie uit die 1980's, "Duitswes Wals", ook bekend as "Dans met die rooi rok". ${ }^{11}$ Meer onlangs het De Lange gedien as inspirasie vir die musiekblyspel Die Naglopers, geskryf deur Rian Malan en uitgevoer deur die Radio Kalahari Orkes, wat ook 'n CD van sy musiek vrygestel het in 2007. Dit het als grootliks bygedra tot die mitologie agter die man. Hy is deur Malan geromantiseer as 'n buitestaander, 'n harde drinker, hoereerder en anti-held en was die verpersoonliking van rebellie lank voor die Afrikaanse rock van Anton Goosen en Koos Kombuis. ${ }^{42}$

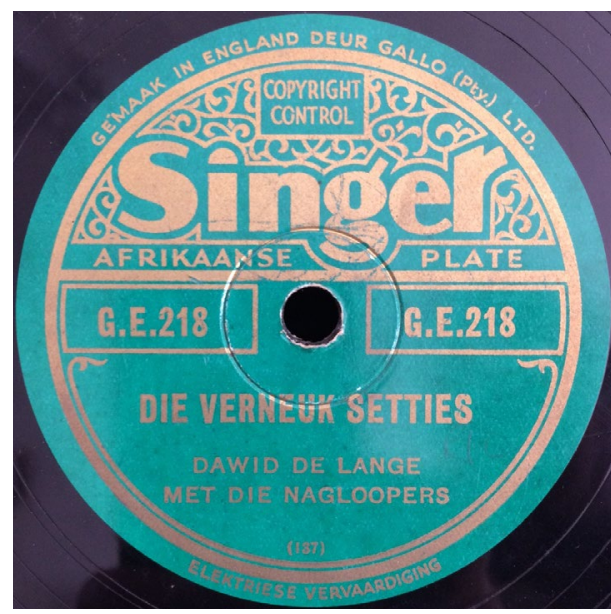

Gallo se Singer-handelsmerk, met David de Lange se "Die Verneuk Setties" (G.E. 2।8).

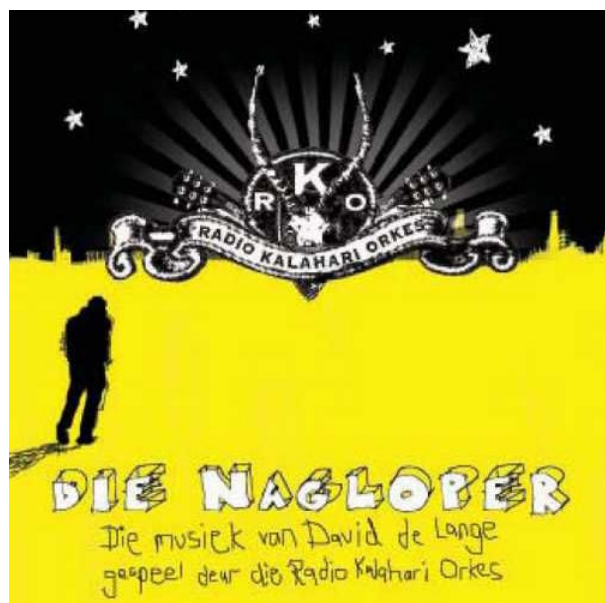

Radio Kalahari Orkes se weergawe van David de Lange se musiek op die album Die Nagloper in 2007, 60 jaar ná sy dood (Sony BMG Terracd0I).

Gedurende hierdie oplewing van sy werk het'n debat ontstaan op die Afrikaanse webtuiste Litnet oor die spelling van sy naam en waar hy gebore (en oorlede) is. ${ }^{43}$ In hierdie korrespondensie is daar 'n verwysing deur Rob Allingham na 'n brief geskryf deur die uitvoerende raad van die FAK aan die nuutgevormde SAUK - waarskynlik in 1937 of 1938 - wat versoek het dat De Lange se musiek nie uitgesaai word nie omdat die standaard te laag is en dit 'n vernedering is vir die Afrikanerkultuur. Dis onduidelik of hierdie brief die hoofmotivering was (en of dit nog enigsins bestaan), maar ander bronne bevestig wel dat die SAUK nooit sy musiek uitgesaai het nie. Desondanks die feit dat hy honderde duisende plate verkoop het. ${ }^{44}$ In 1936, dieselfde jaar wat die SAUK gestig is, het hy die eerste opname vrygestel van "Suikerbossie", een van die grootste treffers van die 1930's en tot vandag toe een van die bekendste Afrikaanse liedjies. ${ }^{45}$ 'n Engelse vertaling van "Suikerbossie" - "Sugar Bush" - is in 1952 in die VSA deur Doris Day en Frankie Lane vrygestel, en het blykbaar die top tien op die Amerikaanse treffersparade bereik. ${ }^{46}$

41 Ibid.

423 Julie 2006, http://www.oulitnet.co.za/senet/senet.asp?id=48859 [besoek 23 Augustus 2012]; sien ook T. Engelbrecht, “Die Souties wat 'n seties laat swing”, Rapport, 28 November 2009.

43 Verskeie briewe is op hierdie platform geskryf tussen Julie en September 2006, beskikbaar by http://www.oulitnet.co.za/senet/senet.asp?id=48859 [besoek 23 Augustus 2012].

44 http://www.boeremusiek.org/orkesteenkarakters.html\#DawidDeLange [besoek 23 Augustus 2012].

45 Ibid.; sien ook Pretorius, Musieksterre van gister en vandag, p. 60.

46 Pretorius, p. 26. 


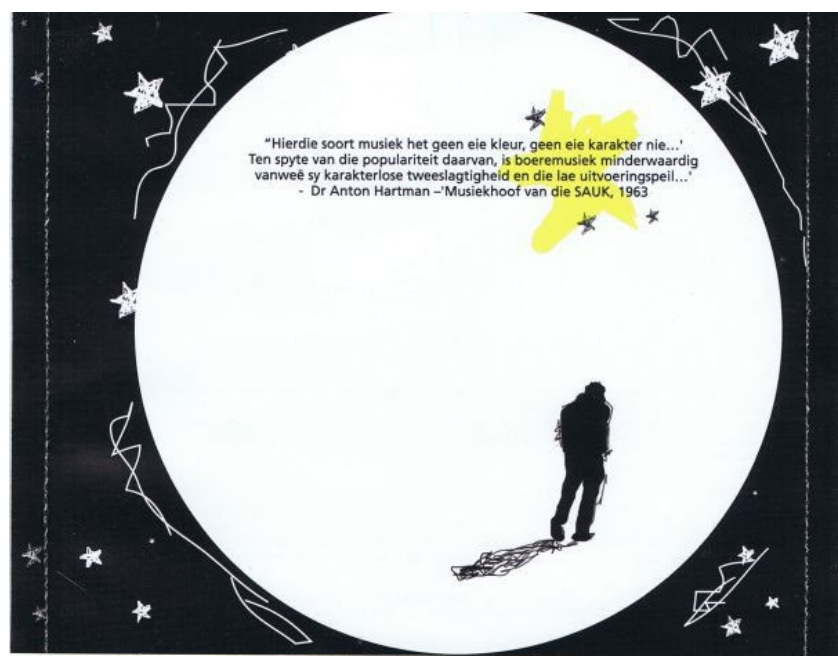

"Hierdie soort musiek het geen eie kleur, geen eie karakter nie ... Ten spyte van die populariteit daarvan, is boeremusiek minderwaardig vanweë sy karakterlose tweeslagtigheid en die lae uitvoeringspel ..." - Dr Anton Hartman, Musiekhoof van die SAUK, 1963." - Die binne-omslag van Die Nagloper.

De Lange se musiek was ten minste nie heeltemal verlore vir Suid-Afrikaanse luisteraars nie, aangesien LM Radio (Radio Lourenço Marques) in Mosambiek'n daaglikse program uitgesaai het met net David de Lange liedjies, wat deur Arthur Swemmer (later 'n bekende akteur) aangebied is. ${ }^{47}$ LM Radio is gestig in 1935 en het vir 'n hele paar dekades vir Suid-Afrikaanse luisteraars musiek gespeel wat die SAUK ongunstig geag het. Mense kon selfs LM Radio uitsendings so ver as Kaapstad optel. Baie van die programme was spesifiek bedoel vir Suid-Afrikaanse gehore, en Suid-Afrikaners kon selfs dienste en produkte op LM Radio adverteer. ${ }^{48}$

De Lange se lirieke kon net sowel die rede gewees het dat die uitvoerende raad van die konserwatiewe FAK hulle rug op hom gedraai het, aangesien dit dikwels gehandel het oor dronkenskap en hoereerdery. Die volgende uittreksels is goeie voorbeelde:

... Sewe jaar het ek na haar gevry, en die agste jaar toe verneuk sy vir my ..." Eers was ek 'n dronklap ..." .... Ver van Christiana het Pop-eye San gebly, Sy was ook glad nie mooi, maar maggies sy kon vry ..." "Babbelaas se ouma woon in Boomstraat ..." "Hartebeespoortdam is 'n lekker plek. Dis waar die nooiens van brandsiek vrek ... ${ }^{49}$

Hierdie teenstrydigheid het nie die platemaatskappye regtig geraak nie. Trouens, De Lange se sukses was krities vir die finansiële oorlewing van Gallo gedurende hierdie tyd. In 1938, met die Eeufeestrek wat die verbeelding van soveel Afrikaners aangegryp het, het Singer die geleentheid gebruik om 'n spesiale herdenkingsalbum vry te stel met 'n verskeidenheid van Afrikaanse musiekgenres, van die "Transvaalse Volkslied" en gewyde liedere (met die instruksie dat hulle

47 Pretorius, Musieksterre van gister en vandag, p. 59; sien ook http://www.boeremusiek.org/orkesteenkarakters. html\#DawidDeLange [besoek 23 Augustus 2012].

48 http://lmradio.org/History.html [besoek 30 April 2013].

49

Opskommel 4, 1990, p. 2. 
met Kersfees en Nuwejaarsvieringe gesing moet word) tot liedjies deur David de Lange. ${ }^{50}$ So 'n mengsel sou baie onwaarskynlik gewees het as die FAK enige sê in die saak gehad het. Ten spyte van die prys het die plate goed verkoop. Selfs al het sy werkersklas-verwysings die Afrikaner kulturele elite van die FAK omgekrap, was hulle'n klein minderheid. Giliomee skat dat die totale Afrikaner-bevolking net oor 'n miljoen beslaan het teen die middel 1930's, ${ }^{51}$ wat beteken het dat een uit elke twee Afrikaners waarskynlik 'n David de Lange plaat besit het. Dit is weliswaar onmoontlik om presies te weet wie sy gehoor was. Met die hoeveelheid plate wat hy verkoop het moes hy 'n wye ondersteuningsbasis gehad het in die stede en die platteland.

Die liedjieskrywende paartjie Cissie en Willie Cooper het baie gewilde liedjies gedurende die 1930's geskryf, onder andere Chris Blignaut se grootste kommersiële treffer, "Die Donkie". ${ }^{52}$ Hulle loopbaan is egter ernstig geknou deur die Tweede Wêreldoorlog, vanweë die ontwrigting veroorsaak deur Duitse duikbote, asook die feit dat slegs noodsaaklikhede per skip verstuur is. ${ }^{53}$ Musiekmeesters, wat tot op hierdie punt per skip van die Kaap na Brittanje gestuur is om daar gedruk te word, was nie noodsaaklike items in oorlogstye nie. Selfs 'n hele stapel gedrukte enkelsnitte van "Voortrekker Dans" wat op pad was Kaapstad toe moes in Southampton afgelaai het om plek te maak vir meer noodsaaklike goedere. ${ }^{54}$

Die paartjie het veral ook liedjies geskryf wat verwys het na politiese en sosiale gebeurtenisse van die 1930's, wat ongewoon was onder Afrikaanse liedjieskrywers van die tyd. Hulleliedjie "Koalisie" is geskryf ná Smuts en Hertzog se samesmelting in 1934, en hulle het "Voortrekker Nooi" en "Voortrekker Dans" vir die 1938 Eeufees-vieringe geskryf. ${ }^{55}$ Die Smuts-Hertzog samesmelting het lojaliteite onder die Afrikaners verdeel - met die opposisie Afrikaner-groep wat 'n sentrale rol gespeel het in die organisasie van die Eeufeestrek. Soos dit was met Chris Blignaut, wat kon grap met beide die Natte en die Sappe ${ }^{56}$ het die Coopers klaarblyklik'n pragmatiese benadering gehad as dit by politiek gekom het.

Met die stigting van 'n toegewyde Afrikaanse diens van die SAUK in 1937 het daar vraag ontstaan na meer Afrikaanse musiek, en musikante - veral beroepslui - het hulleself aangepas by die veranderende landskap. Wat dit betref was die orkesleier, Hendrik Susan, die voorloper. ${ }^{57}$ Susan het sy musiekloopbaan in die 1920's in Lourenço Marques en toe Salisbury begin, voor hy teruggekeer het Suid-Afrika toe om in hotelle en danssale in en om Johannesburg te speel. Hy het sy musiekloopbaan gestaak om te gaan boer tussen 1929 en 1932, toe die Groot Depressie dit nog moeiliker gemaak het om op musiek as op die landbou te oorleef. Hy het teruggekeer na musiek in 1933 toe hy sy eerste opnames vir Columbia gemaak het. In 1937 het Gideon Roos

50 Advertensie vir Singer-plate in Die Transvaler, 2 Desember 1938, aangehaal in W. Froneman, "Seks, Ras en Boeremusiek: agter die retoriek van gebrekkige sanglus by die 1938-Voortrekkereeufees", Litnet Akademies, 11:2 (2014), p. 428.

51 Giliomee, Die Afrikaners, p. 323.

52 Ibid., p. 40.

53 Cissie Cooper, aangehaal in Trewhela, Song Safari, p. 43.

54 Ibid., p. 44.

55 Ibid., p. 43.

56 Bester, Tradisionele Boeremusiek, p. 78. Natte het oorspronklik verwys na die ondersteuners van Hertzog se NP en het later die nasionaliste wat Malan ondersteun het ingesluit, terwyk Sappe verwys het na die ondersteuners van Smuts se Suid-Afrikaanse Party.

57 Vir 'n meer gedetailleerde beskrywing van Susan se loopbaan, sien Froneman se Pleasure Beyond the Call of Duty, pp. 126-135. 
en Pieter de Waal - wat een van die eerste Afrikaanse uitsaaiers op die JB-diens van die ABC was $^{58}$ - Susan genader om 'n orkes te stig wat Afrikaanse musiek regstreeks op die lug sou uitsaai vir die SAUK. ${ }^{59}$ Veral De Waal was invloedryk en het baie gewilde koffiehuiskonserte gereël wat regstreeks uitgesaai is. De Waal en Susan het'n moderner klank geskep om die veranderende tye te pas en het weggebreek van die normale vastrap-boeremusiek wat tot op daardie punt so gewild was. Susan het van 'n ander musikale agtergrond gekom en het meer moderne instrumente tot die genre ingevoer soos klavier, saksofoon en elektriese kitaar, in plaas van die normale banjo, konsertina en viool. Die ontwikkeling van hierdie styl was die gevolg van suiwer innovasie. Omdat daar 'n groot tekort was aan gewilde Afrikaanse liedjies het hulle kort voor lank die FAK se Volksangbundel - ten tyde die mees omvattende versameling genoteerde Afrikaanse musiek - uitgeput en baie van die liedjies verwerk. Hulle daaglikse regstreekse optredes op die radio het hulle dalk in 'n ander klas geplaas as die alledaagse groepe wat slegs nou en dan op 'n danspartytjie gespeel het en wat kon wegkom met 'n meer beperkte repertoire. Daar moes ook 'n tipe status gewees het wat daarmee gekom het om in Susan se orkes te speel. Hy het homself met die beste musikante wat hy kon vind omring (waarvan baie nie Afrikaners was nie), en vir baie jare het sy span gedien as 'n wegspringplek vir suksesvolle solo-loopbane, veral dié van Nico Carstens, wat in 1945 by die groep aangesluit het. Die spelers is goed betaal, sommige het ook oorspronklike materiaal gekomponeer vir uitvoering en uitsending, en vanaf die laat 1940's het hulle in rolprente verskyn. Dit was 'n kommersiële dimensie ver verwyderd van die boereorkeste wat bestaan het uit myners, transportryers, bywoners en dies meer wat gedurende die 1930's opgeneem het. Hierdie nuwe genre het bekend geraak as "ligte Afrikaanse musiek." ${ }^{60}$ Soos Flippie Luyt, een van sy orkeslede, dit onthou:

Pieter suggested that he form a group or duo to do Afrikaans music over the
air. Susan was enthusiastic, but being a proper musician himself - he had played
violin and sax with the Jazz Maniacs at the Orange Grove - he wanted something
more than the old Boereorkes ... That was the start of this sort of music, and
it was left to Susan and myself to arrange songs out of the FAK Sangbundel for
our programmes. ${ }^{61}$

Luyt se verwysing na die Jazz Maniacs is fassinerend. Daar was twee groepe met dié naam in Johannesburg gedurende die 1930's en 40's, een wit en een swart, en die laasgenoemde Jazz Maniacs (Solomon "Zuluboy" Cele en Wilson Silgee se orkes) was veral bekend vir hulle marabi-jazz. ${ }^{62}$ Marabi was 'n swart musiekstyl wat in die agterbuurte van Johannesburg ontwikkel het en die basis gevorm het van 'n lewendige ondergrondse musiekkultuur (wat ongelukkig meesal nie opgeneem is nie) wat gekoppel is aan 'n verskeidenheid euwels soos onwettige alkoholneste en prostitusie. ${ }^{63}$ Daar was ooreenkomste tussen marabi en boeremusiek.

58 Rosenthal, You have been listening, p. 132.

59 D.C. Pretorius, p. 224.

60 Freddie Luyt het die term uitgedink in 1942.

61 Freddie Luyt, onderhoud in Trewhela, Song Safari, p. 50.

62 Ballantine, Marabi Nights, p. 98.

63 R. Allingham, "South Africa - Popular Music: Nation of Voice", in S. Broughton, M. Ellingham, and R. Trillo (reds.), World Music: The Rough Guide. Africa, Europe and the Middle East, South Africa - Popular Music: Nation of Voice Vol. 1 (Londen: Rough Guides, 1999), p. 639. 
Albei is geag as sondig, kontroversieel, alledaags, en is met die werkersklas geassosieer. ${ }^{64}$ Die sukses van sommige van die marabi-kunstenaars het van die wit musikante met 'n mate van jaloesie vervul, en hulle het die gereg gebruik om hulle optredes te dwarsboom. Daar moes egter 'n mate van respek gewees het want Cele en Silgee se groep het blykbaar "elke nou en dan die leiding van 'n Europese vriend" geniet. ${ }^{65}$ Die versoeking is groot (en selfs 'n bietjie moedswillig) om die moontlikheid te ondersoek dat Susan sy hand aan marabi-jazz gewaag het saam met swart musikante en ten minste deels beïnvloed is deur die ervaring (wat sou beteken dat latere ligte Afrikaanse musiek se wortels oor die rassegrens gekruip het, ens.). Om billik te wees is daar nie regtig enige bewyse nie, en hy sou waarskynlik eerder saam met die wit Jazz Maniacs - wat die ander groep uitgedaag het oor die aanspraak op die naam - gespeel het. Dinge het egter nie vir hulle uitgewerk nie. In een van die meer buitengewone musikale oomblikke van die 1930's in Johannesburg het 'n regter die twee orkeste beveel om aan 'n uitspeelwedstryd deel te neem (moontlik die eerste 'battle of the bands' in Suid-Afrikaanse geskiedenis?) om te bepaal watter een van hulle die beste was. Cele en Silgee se groep het gewen. ${ }^{66}$

Aangesien hy alreeds 'n greintjie roem verwerf het met van sy vroeë regstreekste Afrikaanse musiek uitsendings, was Susan in die perfekte posisie om te kapitaliseer op die 1938 Eeufeestrek en die nuwe golf van Afrikaner nostalgie. Sy orkes het saam met die ossewaens getrek en gereeld langs die pad optredes van Afrikaanse musiek uitgesaai. Susan se verbintenis met die Trek het hom landswye roem besorg, en sy latere toere - insluitend van Suidwes-Afrika - was hoogs suksesvol. Dit het van hom 'n groot Afrikaner-gunsteling gemaak, en vir baie jare daarna is hy as 'n kampvegter geag vir die NP, 'n posisie waarmee hy blykbaar gemaklik was solank dit winsgewend was. ${ }^{67} \mathrm{Hy}$ het egter wel per geleentheid betaling van die plaaslike NP hoofde in plattelandse dorpe geëis as hulle politiek die Sappe daarvan weerhou het om sy optredes by te woon. ${ }^{68}$

In 'n interessante skuif, uit 'n politieke perspektief, is 'n versoek gestuur aan die FAK om Susan se groep amptelik met die organisasie te affilieer, maar die versoek is in Julie 1939 van die hand gewys. Die verduideliking was dat slegs koöperatiewe ondernemings met die FAK kon affilieer, en Susan se orkes was 'n privaat onderneming. ${ }^{69}$ In die SAUK se jaarverslag van 1939 is Susan egter geloof vir sy bydrae tot die herlewing van ou volksliedjies. ${ }^{70}$ As mens in ag neem dat die FAK en die SAUK 'n gespanne verhouding gehad het gedurende die laat 1930's en vroeë 1940's, is dit koddig, maar nie noodwendig vreemd nie. Susan se vroegste uitsendings vir die SAUK was afhanklik van die beperkte hoeveelheid genoteerde Afrikaanse musiek wat ter tyde beskikbaar was, waarvan die pas-gepubliseerde FAK Volksangbundel die belangrikste was. Die beeld wat na vore kom, dui daarop dat hy en sy kollegas by die SAUK jazzerige weergawes gespeel het van die volksliedjies wat in die Volksangbundel genoteer is. Op 'n stadium - waarskynlik iewers tydens die Tweede Wêreldoorlog - net voor 'n regstreekse uitsending, het die nuus deurgekom dat die

64 Ballantine, Marabi Nights, p. 8.

65 Umteteli wa Bantu, 18 Maart 1939, aangehaal in Ballantine, Marabi Nights, p. 45.

66 C. Ballantine, Marabi Nights, pp. 98-99.

67 Ibid., sien ook Trewhela, Song Safari, p. 51.

68 Ibid., p. 51.

69 Notule van FAK Uitvoerende Raadsvergadering, 4 Julie 1939, (INCH), FAK Versameling, PV 1/3/1/1/1/.

70 P.J. van der Walt, "Die S.A.U.K., met spesiale verwysings na sy verhouding tot die staat", MA Verhandeling, Potchefstroom Universiteit, 1973, p. 195. 
SAUK nie meer liedjies uit die Volksangbundel sou uitsaai nie. ${ }^{71}$ Hoewel dit die spanning tussen die SAUK en die FAK op daardie stadium weerspieël het, het musikante dikwels aangepas by beleidsveranderinge sonder om direk betrokke te raak:

\section{Both De Waal and Susan's financial inclinations support the argument that the relationship between politics and popular culture in white Afrikaans twentieth- century South Africa was more complex than merely one of co-operation by the political. Under the influence of De Waal - who, as mentioned earlier, had a keen eye for commercial opportunities - ligte Afrikaanse musiek exploited nationalist sentiments. ${ }^{72}$}

Gedurende die Tweede Wêreldoorlog het hy optredes geopen met "God save the King", wat verpligtend was, en dit onmiddelik opgevolg met "Kent gij dat volk" - die ou Translvaalse nasionale volkslied. Dit het hom vlugtig onder die aandag van die regering van die dag gebring, wat kon lei tot internering, hoewel niks ooit daarvan gekom het nie. ${ }^{73}$ Dis ook noemenswaardig dat hy aanbiedinge van die hand gewys het om te staan as 'n lid van die Volksraad en om die militêre orkes te lei (waarmee hy die rang van kolonel sou verdien). ${ }^{74}$

Susan was eufemisties bekend vir sy 'vrygewigheid', wat Froneman verduidelik as verwysings na sy dobbel-verslawing. ${ }^{75}$ Susan het, egter, dikwels geld geskenk vir Afrikaner-sake. Een hiervan was die Reddingsdaadbond, waarvoor hy gekritiseer is deur die konserwatiewes omdat die geld ingesamel is deur dans. ${ }^{76}$ Die ander was om 'n Afrikaanse teater in Johannesburg op te rig. Froneman twyfel tereg of die meeste gewilde boereorkeste van die laat 1930's en 1940's polities aktief was of nie, ${ }^{77}$ en dit is twyfelagtig of Susan polities geaffilieer was met Afrikanernasionalisme, hoewel hy sy hele loopbaan lank by nasionalistiese gebeurtenisse sou optree.

Sommige ander Afrikaanse kunstenaars was meer partydige ondersteuners van die nasionalistiese saak. Een voorbeeld was die Stellenbosch Boereorkes wat in 1933 deur "Oom Pietie" le Roux gestig is. Die leuse van die orkes was “Ons eie”, en lede is opgeroep van die Universiteit Stellenbosch en uit die dorpsmense. Lede moes ten alle tye Afrikaans praat en hou by 'n "erkende Afrikaanse gedragskode", wat onder andere rook en naelpolitoer verbied het. Die groep was baie gewild en het talle kere deur Suid-Afrika en Suidwes-Afrika getoer. ${ }^{78}$ Hulle was nie winsgedrewe nie en het aansienlike bedrae geld geskenk, spesifiek aan Afrikaner-sake, soos die Voortrekkermonument ( $£ 6$ 240) en die Reddingsdaadbond ( $£ 17508$ ). ${ }^{79}$ Die orkes het ook geld geskenk aan die FAK, die Afrikaanse Taal- en Kultuurvereniging (ATKV) en die Afrikaanse Christelike Vrouevereniging (ACVV). Bester noem dat die Stellenbosch Boereorkes op die ou einde 'n totale bedrag van

71 Ibid., p. 132.

72 Froneman, "Pleasure beyond the call of duty", p. 135.

73 Ibid.

74 Bester, Tradisionele Boeremusiek, p. 68.

75 Froneman, "Pleasure beyond the call of duty", p. 130.

76 Ibid., p. 65.

77 Ibid., p. 129.

78 B.E. van Blerk, Handhaaf, April/ Mei, 1988, p. 9.

79 Ibid. 
meer as R100 000 - 'n aansienlike bedrag op daardie stadium - ingesamel het. ${ }^{80}$ Hierdie nou affiliasie het beteken dat hulle slegs voor spesifieke gehore opgetree het, en dat hulle optredes moes voldoen aan spesifieke voorgeskrewe kulturele vereistes, wat verskil het van ander gewilde groepe van die tyd.

Danie Bosman was nog 'n gewilde liedjieskrywer wat van die mees geliefde liedjies van die 1930's en 40's vervaardig het. In 1932 het hy Engelse liedjies begin skryf saam met Anton de Waal (wat 'n uiters suksesvolle vennootskap met Nico Carstens sou hê, wat later bespreek sal word), maar hulle pogings was meesal onsuksesvol. Op sy eie het hy egter in Afrikaans begin skryf en het hy 'n mengsel vervaardig van gewilde dansliedjies, waarvan "Kaapse Draai" 'n goeie voorbeeld is, asook meer ernstige komposisies soos "Boereseun". Hendrik Susan het ook van sy materiaal opgeneem. Sy musiek het uitgestaan bo baie ander liedjies van die tyd, en hy is beskou as een van die mees begaafde populêre musiekskrywers van sy generasie. ${ }^{81}$ Daar het later, in die 1960's, 'n rolprent oor sy lewe verskyn, met Frans Marx wat die rol van Bosman vertolk het. Sy musiek word vandag nog by konserte opgevoer. Hy is in 1946 op die ouderdom van 39 aan kanker oorlede.

Dit was pure toeval, of miskien nie, dat tegnologiese vooruitgang in klankopname en die druk van plate, sowel as in radio-uitsaaiwese, dit moontlik gemaak het vir Afrikaanse kunstenaars soos Chris Blignaut, David de Lange, die Coopers, Danie Bosman, en Hendrik Susan om landswye roem te verwerf net toe die ideologie van Afrikanernasionalisme begin momentum kry het. Aan die ander kant van die rassespektrum was marabi. Terwyl David de Lange honderde duisende plate verkoop het, is vroeë marabi-kunstenaars se musiek egter nie opgeneem nie. Opnames van swart musiek gedurende hierdie tyd het meesal gefokus op koorwerk en die musiek van die mynkampe rondom Johannesburg, wat nie veel in gemeen gehad het met die Afrikaanse musiekstyle van die tyd nie. Ander het kommentaar gelewer oor die onderlinge invloed van boeremusiek, marabi en ghoemaliedjies (wat onder die bruin bevolking van Kaapstad ontwikkel het). ${ }^{82}$ Marabi het ontwikkel en mbaqanga en kwêla geword, style wat saam met ghoemaliedjies 'n groot invloed sou hê op boeremusiek vanaf die 1950's. Waar die desperaat arm stedelike gebiede - swart en wit - van die eerste helfte van die twintigste eeu tekortgeskiet het in terme van werk en inkomste, het hulle opgemaak as van die belangrikste en lewendigste ruimtes vir die ontwikkeling van plaaslike musiekstyle, dikwels met veelrassige invloede.

\section{Radio}

In vergelyking met die opnamebedryf het die geskiedenis van radio-uitsaaiwese in Suid-Afrika, soos reeds genoem, meer direkte skakels met die politieke ontwikkelinge van die twintigste eeu. Omdat die televisie eers baie laat aan Suid-Afrika bekendgestel is (1976), was radio die enigste uitsaaimedium vir meer as vyf dekades. Gedurende hierdie tyd was dit 'n deurlopende ideologiese slagveld, nie net tussen die twee wit taalgroepe nie, maar ook binne die groepe self,

80 Bester, Tradisionele Boeremusiek, p. 62.

81 Pretorius, pp. 25-26.

82 Sien D. Martin, Sounding the Cape: Music, Identity and Politics in South Africa (Somerset-Wes: African Minds, 2013), p. 143. 
om die maatskaplike rol te bepaal wat hierdie "konstante metgesel van die mens" 83 sou beklee. Die aard van uitsaaiwese maak dit uiters vatbaar vir 'n politieke magstryd, en in die konteks van vroeë Suid-Afrikaanse radio, is dit gedefinieer deur spanning rondom taal. ${ }^{84}$ Soos genoem in die vorige hoofstuk het Engelse uitsendings die vroeër fases van Suid-Afrikaanse radio gedomineer. Hierdie marginalisasie van Afrikaans deur die $\mathrm{ABC}$ het gelei tot 'n veldtog vir meer Afrikaanse progamme ${ }^{85}$ wat in 1931 deur die Broederbond ${ }^{86}$ van stapel gestuur is. Uiteindelik sou die ABC 90 minute lank in Afrikaans uitsaai per dag, wat nie genoeg was vir die Afrikaanse drukgroepe nie. ${ }^{87}$ Hoewel die ABC eksklusiewe uitsaairegte in Suid-Afrika gehad het, was die aantal lisensies min, wat verdere finansiële moeilikheid veroorsaak het in die korporasie se vroeë jare, en aanleiding gegee het daartoe dat Isidor Schlesinger, die maatskappy se stigter en president, die regering versoek het om die organisasie by hom te koop - 'n versoek wat van die hand gewys is. ${ }^{88}$

Teen 1933 het Hertzog se regering, bewus van die potensiële mag van die uitsaaiwese en van die probleme wat bestaan weens die ongelykheid tussen Engels en Afrikaans, vir Sir John Reith, ten tyde die Direkteur-Generaal van die BBC, versoek om die moontlikheid te ondersoek vir die regering om die radiodiens oor te neem. Reith het 39 dae spandeer om onderhoude te voer met meer as 250 verteenwoordigers van oral oor Suid-Afrika ${ }^{89} \mathrm{Hy}$ het bevind dat radio van kardinale belang was vir Suid-Afrika, maar dat tegniese uitdagings dit onmoontlik gemaak het vir 'n privaat organisasie om omvattende programmering te bied. Hy het wetgewing aanbeveel wat die oprigting van 'n publieke uitsaaier toelaat. Die regering sou dit besit, maar nie noodwendig voorskryf nie..$^{90}$

Hierdie raad is gebaseer op die BBC model, wat verskil het van die gedeeltelik kommersiële Amerikaanse model van die ABC. Oor die algemeen het die Suid-Afrikaanse publiek die Reith-Verslag positief ontvang, maar die Suid-Afrikaanse regering se besluit om die ABC uit te koop en 'n nasionale uitsaaigesag te stig is uitgestel tot 1936, na uitgerekte onderhandeling tussen die twee partye. Bowendien sou die veranderende politieke landskap - veral onder Afrikaners ná Hertzog en Smuts se samesmelting - lei tot vurige debatte in die Parlement gedurende April en Mei 1936 oor die manier waarop radio-uitsaaiwese bestuur sou word. Die nuut-gestigte

83 Om C. Hamm aan te haal, “The constant companion of man': Separate Development, Radio Bantu and music”, Popular Music, 10:2, (1991), pp. 147-173.

84 Hierdie spanning is gebaseer op die aanname dat Afrikaans as 'n taal en kultuur bedreig word. Dit is 'n onderwerp wat tot vandag toe nog op 'n formele vlak voorkom in debatte (en hofsake) oor die gebruik van taal in tersiêre onderrig. Op 'n meer informele vlak is dit ook'n deurlopende tema in populêre Afrikaanse musiekoptredes (sien Hoofstuk Sewe).

85 G. Hayman \& R. Tomaselli, "Ideology and Technology in the Growth of South African Broadcasting, 1924-1971", in R. Tomaselli, K. Tomaselli \& J. Muller (reds.), Currents of Power: State Broadcasting in South Africa (Kaapstad: Anthropos, 1989), p. 29.

86 Die Broederbond was 'n geheime organisasie van vooraanstaande Afrikaners en het dikwels by politiek betrokke geraak. Die organisasie is in 1918 gestig.

87 G. Hayman \& R. Tomaselli, "Ideology and Technology in the Growth of South African Broadcasting, 1924-1971", in R. Tomaselli, K. Tomaselli \& J. Muller (reds.), Currents of Power: State Broadcasting in South Africa (Kaapstad Anthropos, 1989), p. 29.

88 Ibid.

89 E. Rosenthal, You have been listening: The early history of Radio in South Africa (Kaapstad: Purnell, 1974), pp. 153-154; sien ook G. Roos, "Die Uitsaaiwese in Diens van ons Samelewing”, referaat gelewer by die FAK Buitengewonne Volkskongres, 7 Augustus 1957, Stellenbosch, p. 2. 
Gesuiwerde Nasionale Party het die debatte gebruik om die beginsel van Afrikaner kulturele soewereiniteit - hulle enigste politieke kapitaal op dié tydstip - sover as moontlik te neem.

Paul Sauer, verteenwoordiger van die Afrikaner nasionalistiese opposisie, het sy kiesers se besware bondig saamgevat en was merkwaardig profeties oor die spanninge wat kort ná die stigting van die SAUK sou verskyn:

With regard to the African Broadcasting Company, I want to say that after a very long and hard struggle, the Afrikaans language has come partly into its rights. I trust that, so far as this is concerned, we shall have no more complaints when the new Corporation is established... There always was throughout subtle imperialistic propaganda to which many people in South Africa strongly objected. I hope that when we have our service in South Africa as regards the broadcasting of news, it will be done in an objective manner ...91

Hy het ook die kwessie van klas geopper deur voor te stel dat plattelandse luisteraars (wat oorwegend Afrikaans was), wat oor die algemeen veel slegter ontvangs gehad het, laer lisiensiefooie behoort te betaal. ${ }^{92}$ Radiolisensies in Suid-Afrika was die duurste in die wêreld op daardie stadium, wat dit moeilik gemaak het vir Afrikaners om dit te bekostig. As hulle afslag kon kry op lisensiefooie, sou meer Afrikaners radio luister. Boonop was die gesuiwerde nasionaliste ten gunste van 'n Radio-raad wat slegs uit tweetalige verteenwoordigers bestaan het. Dit sou in die guns van die Afrikaanssprekende bevolking getel het, omdat baie Afrikaners tweetalig was, terwyl nie baie Engelssprekendes was nie. Op hierdie manier sou onlangse Engelssprekende immigrante nie op die Radio-raad kon dien totdat hulle geleer het om Afrikaans te praat nie.

Aan die ander kant van die politieke spektrum, het C.F. Stallard, leier van die Dominion Party en verteenwoordiger vir Roodepoort (wat dikwels as 'n jingoist beskou is), die volgende reguit stelling gemaak oor die rol van kulturele organisasies, waarskynlik met verwysing na die FAK:

... (W)hat the country desires and looks for is that this utility corporation when established, shall have no political bias of any sort, kind or description: that it shall represent the people as a whole, and not get into the hands of anybody, the Government included, who can use it for probably propaganda purposes, or as a teaching organisation for teaching what the listeners do not want to be taught. There are plenty of cultural organisations that can do that. I have yet to learn that cultural organisations are best qualified to speak from the public point of view. ${ }^{93}$

My information is that the existing broadcasting corporation throughout its career has been deluged with protests and applications from these cultural societies. ${ }^{94}$

Hoewel Stallard nooit aangedui het watter 'kulturele vereniginge' hy bedoel nie, dien Hayman en Tomaselli se verwysing na die 1931 veldtog deur die Broederbond as 'n voorbeeld..$^{95}$ Die

91 Unie van Suid-Afrika, Debatte van die Volksraad, Vierde Sessie, Sewende Parlement, Vol. 26, 29 April 1936, p. 2728.

92 Ibid., pp. 2732-2733.

93 Ibid., p. 3829.

94 Ibid., p. 3838.

95 Hayman \& Tomaselli, "Ideology and Technology in the Growth of South African Broadcasting, 1924-1971", p. 29. 
impak van hierdie veldtog was waarskynlik beperk, aangesien daar geen aanmerklike toename in Afrikaanse progamme was voor die stigting van die SAUK se toegewyde Afrikaanse diens nie. Die probleem was hoofsaaklik dat, anders as in die VK met sy hoë vlak van kulturele en linguistiese homogeniteit, daar diep verdeling tussen die Afrikaans- en Engelssprekende groepe in wit Suid-Afrika was, en vrese oor kulturele dominasie deur die ander het debatte oor die onderwerp gedomineer. Die basiese posisie van die nasionaliste was een wat Afrikaans beskou het as 'n bedreigde taal wat apart gehou moes word om gelykwaardigheid met Engels te kon bereik. Afrikaanse kultuur is gesien as onder-gekommoditeer, met te min hulpbronne waaruit materiaal vir die uitsaaiwese geput kon word. Hierdie benadering was teenstrydig met Smuts en Hertzog se twee-stroom beleid wat 'n gedeelde Suid-Afrikaanse identiteit tussen wit Engelsen Afrikaanssprekers op gelyke terme aangemoedig het. ${ }^{96}$ Desnieteenstaande het alle partye saamgestem dat 'n nasionale uitsaaier opgerig moet word in die plek van die ABC, wat die Afrikaanse kontingent eintlik gepas het. Teen hierdie tyd het Schlesinger dit egter reggekry om die korporasie se finansiële situasie om te draai en was hy minder entoesiasties om dit te laat gaan, maar hy was regtens magteloos ná die proklamering van Wet no 22 van 1936, wat gelei het tot die stigting van die SAUK en hom effektief geforseer het om te verkoop. ${ }^{97}$

Deel van die Wet het bepaal dat voorsiening gemaak moet word vir 'n aparte Afrikaanse diens. Dit het gelei tot die oprigting van die eerste uitsluitlik Afrikaanse radio-uitsendings - 'n doel waarna Afrikaner-kampvegters gestreef het vir meer as 'n dekade lank ${ }^{98}$ - op 27 Oktober 1937 wat bekendgestaan het as die "B" diens van die SAUK. As gevolg van sy sterk potensiaal as 'n propagandamasjien moes die verskillende belangegroepe in die parlement tevrede wees dat dit neutraal sou bly voordat die wet goedgekeur kon word. Gevolglik het die Wet gestipuleer dat die uitsaaier geen politieke sienings sou inneem nie. Hierdie ooreenkoms het die Afrikanernasionaliste gepas, want hulle was toe 'n politiese minderheid. Die $£ 150000$ wat gebruik is om die ABC uit te koop is voorgeskiet deur die verskeringsmakelaar Sanlam, ${ }^{99}$ wat 'n sterk Afrikaner nasionalistiese korporatiewe identiteit gehad het. Ten spyte van Sanlam se betrokkenheid was die verhouding tussen die SAUK en die Afrikanernasionaliste teenstrydig gedurende die 1930's. Al het die SAUK van tyd tot tyd ingestem tot versoeke van die FAK - soos wat klaarblyklik gebeur het in die geval van David de Lange - was die korporasie onwillig om by politiek betrokke te raak gedurende die 1938 Eeufeestrek. Hierdie neutraliteit sou 'n moeilike posisie wees om te behou. Maar ongeag daarvan was die oprigting van 'n uitsluitlik Afrikaanse radio-uitsaaidiens 'n belangrike nuwe element in die verspreiding van populêre Afrikaanse musiek na die Afrikaanse publiek.

\section{Die 1938 Eeufeestrek}

Die hoogs gefragmenteerde aard van die Afrikaner-samelewing gedurende die 1930's was ook duidelik sigbaar in die maniere waarop verskillende Afrikaanse koerante die twee hoof opposisie Afrikaner politieke partye ondersteun het. Die Vaderland, Die Suiderstem en Die Volkstem het

\section{Ibid.}

97 Rosenthal, You have been listening, pp. 154-155.

98 Ibid., pp. 131-132.

99 Ibid., p. 159; Hayman \& Tomaselli, "Ideology and Technology in the Growth of South African Broadcasting, $1924-1971$ ", p. 31. 
Hertzog en Smuts se Verenigde Party ondersteun, terwyl Die Burger, Die Volksblad en Die Transvaler pro Malan se Gesuiwerde Nasionale Party was. ${ }^{100}$ Een van die sentrale twispunte was die FAK se pogings om Afrikanerkultuur te verpolitiseer:

In fact, the paper took issue with the Christian National definition of culture; cultural advance came through creative individuals, said an editorial, not through class or ethnic organisation (Die Vaderland, 6 July 1937). More than that, it declared, The FAK had become the political dummy of the purified National Party. If there were a genuine cultural organisation, it would have to bridge political divisions and not simply represent one section of the Afrikaner people (Die Vaderland, 27 May 1938). ${ }^{101}$

Minder as drie maande ná die laasgenoemde artikel het 'n ongehoorde kulturele geleentheid plaasgevind wat die kulturele kapitaal van die FAK aansienlik versterk het, maar ook politieke tweedrag onder Afrikaners oorbrug het. In 'n meesterlike skuif het Afrikaner kulturele entrepreneurs 'n eeufeesviering van die 1838 Groot Trek gereël, waartydens ossewaens die roete na die Noorde gevolg het. Hierdie historiese gebeurtenis se uitbeelding het vir menige die geboorte van Afrikaner-onafhanklikheid en -nasieskap gesimboliseer. Dit het in Kaapstad begin op 8 Augustus 1938 en was, in wese, 'n poging om 'n spesifieke Afrikaner identiteitkultuur uit te druk met ossewaens, Voortrekkerklere, baarde en volkspele wat landwyd versprei is. Die hoogtepunt was die herdenkings by Monumentkoppie buite Pretoria en die plek in Natal waar die Slag van Bloedrivier plaasgevind het. Dit het stedelike Afrikaner werkersklasse aan plattelandse Afrikanerboere verbind onder die vaandel van 'n gedeelde geskiedenis en het ongelooflike ondersteuning geniet. Dit was ook die eerste regte oorwinning vir die opkomende nuwe kultuurpolitiek van die Afrikanernasionaliste in hulle pogings om die Volk te verenig.

Piet Meyer - 'n invloedryke aartsnasionalis en een van die stigterslede van die Afrikaans-Nasionale Studentebond, wat betrokke was by die publikasie van die FAK se Volksangbundel - was instrumenteel in die formalisering van kultuurpolitiek deur sy stigting van die FAK se Nasionale Kultuurraad in Julie 1936. ${ }^{102}$ Hy het twee hoofbedreigings vir Afrikaner-eenheid geïdentifiseer: die Verenigde Party se versoeningsbeleid en "kommunistiesgeïnspireerdeklassekonflikte". ${ }^{103}$ Nie nethet die VerenigdePartydie regering verteenwoordig nie, maar ook kapitaal, terwyl "kommunisties-geïnspireerde" klassekonflikte verbind is aan die opponerende ideologie van Afrikaner sosialisme. In hulle kommentaar op die Eeufeestrek en die opkoms van hierdie spesifieke weergawe van Afrikanernasionalisme, het Grundlingh en Sapire tot min of meer dieselfde gevolgtrekking gekom wat betref ander teenstrydige ideologieë beskikbaar vir Afrikaners op hierdie stadium: sosialisme, soos wat by die Klerewerkersunie gemanifesteer

100 J. Steyn, "Die rol van die Afrikaanse pers in die taalstryd van die 1930s", Ecquid Novi: African Jounalism Studies, 7:1 (1986), pp. 3-16.

101 T. Dunbar Moodie, The Rise of Afrikanerdom: Power, Apartheid, and the Afrikaner Civil Religion (Berkeley: University of California Press, 1975), p. 175.

102 In 1935 het hy sy doktorsgraad aan die Vrije University in Amsterdam behaal en van daar af het hy reise onderneem na die res van Europa, insluitend na Duitsland. In sy outobiografie roep hy goeie herinneringe op van 'n ski-reis in die Duitse Alpe saam met Rudolph Hess, en van 'n keer wat hy Adolf Hitler van naby gesien het, sien P. Meyer, Nog nie ver genoeg nie: 'n Persoonlike rekenskap van vyftig jaar georganiseerde Afrikanerskap (Johannesburg: Perskor, 1984), pp. 11-12.

103 Moodie, The Rise of Afrikanerdom, pp. 169-170; sien ook D. O’Meara, Volkskapitalisme: Class Capital and Ideology in the Development of Afrikaner Nationalism, 1934-1948 (Johannesburg: Ravan Press, 1983), p. 77. 
het, en Suid-Afrikanisme, wat voorgestaan is deur die regering en kapitaal, hoewel 'n "historiese mitologie om te vorm en te manipuleer" by beide van hulle ontbreek het. ${ }^{104}$ Die FAK se moeite om hierdie kwessies aan te spreek was eers tevergeefs - veral by die stembusse gedurende die 1938 verkiesing - maar het 'n merkwaardige ommekeer tot gevolg gehad gedurende die Eeufeestrek. ${ }^{105}$

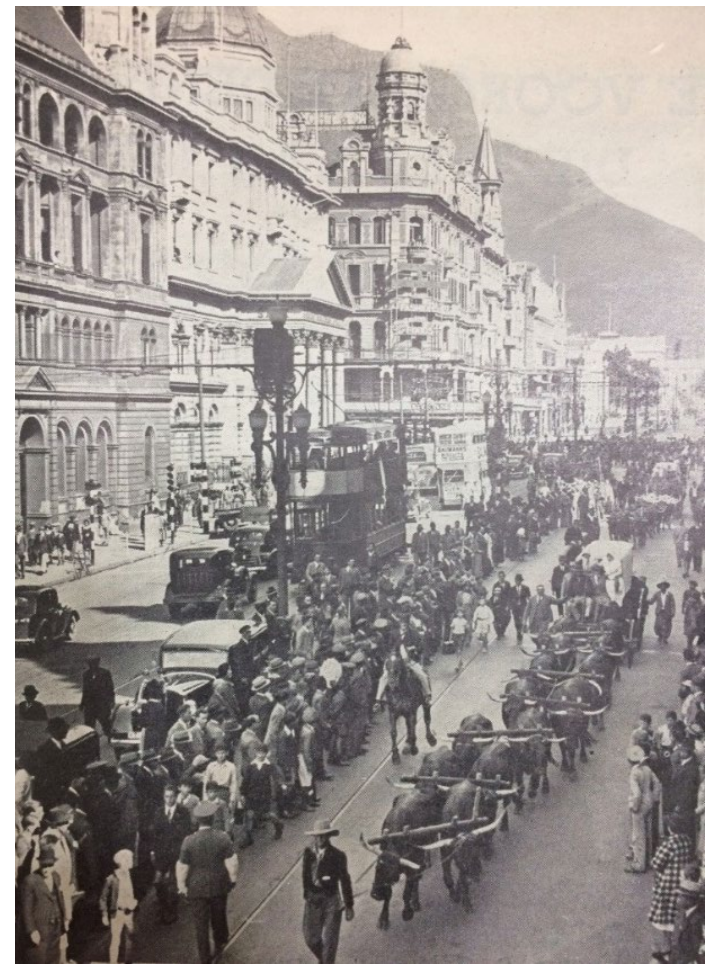

Die eerste skof van die Eeufeestrek: Ossewa in Adderlystraat, Kaapstad. ${ }^{106}$

Hoewel die FAK deel was van die konstellasie van organisasies - polities, godsdienstig en kultureel - wat nou verbind was aan die ideologie agter die Trek, is dit amptelik gereël deur die ATKV, met Henning Klopper aan die stuur. Die ATKV is in 1930 gestig en het sterk bande gehad met werkersklas Afrikaners wat in die laer range van die Suid-Afrikaanse Spoorweë gewerk het, waar daar ernstig teen hulle gediskrimineer is op grond van taal. ${ }^{107}$ Hierdie gevestigde vooroordeel, ten spyte van die regering se tweestroom-taalbeleid, het 'n baie groot rol gespeel in die smee van nasionalistiese politiek. Soos die FAK, het die ATKV ook gefunksioneer as 'n publieke front vir die Broederbond, waarvan Klopper 'n stigterslid was.

104 Ibid., pp. 26-27; sien ook O’Meara se opinie oor hierdie ontwikkelinge in die Inleiding.

105 Ibid.

106 Gedenkboek: Voortrekker-Eeufees, 1938-1939, (Johannesburg: Sentrale Volksfeeskomitee, 1983) p. 33.

107 A. Grundlingh en H. Sapire, "From Feverish Festival to Repetitive Ritual? The Changing Fortunes of Great Trek Mythology in an Industrializing South Africa, 1938-1988”, South African Historical Journal 21 (1989), p. 20; sien ook Giliomee, Die Afrikaners, p. 402. 
Die Trek self het al die pad van die Kaap af tot in Pretoria ongeëwenaarde ondersteuning van Afrikaners gelok. Elke keer as die ossewaens uitgespan het, is daar 'n Afrikaner kulturele fees gehou. Hierdie was plegtige geleenthede waar daar gepreek is, die nie-amptelike Afrikaner nasionale volkslied Die Stem gesing is, waar kore opgetree het en verskeie burgerlike seremonies gehou is. ${ }^{108}$ In die aande is daar gebraai en piekniekliedjies gesing, met orkeste wat gesorg het vir die vermaak. Mans het baarde gegroei om te lyk soos die Voortrekkers van 'n eeu gelede, terwyl vroue kappies en Voortrekkerrokke gedra het. Hierdie modes het help skep aan 'n nuwe denkbeeldige volksgeskiedenis en is ingespan saam met ander kulturele aktiwiteite soos volkspele. Volkspele het nie spesifiek die tradisionele danse van die 19de eeu verteenwoordig nie, maar het in werklikheid die reëls en strukture van Sweedse volksdanse gevolg. Dit het eenvormigheid by groot geleenthede soos Eeufeesvieringe verseker. ${ }^{109}$ Skares van 4000 mense of meer sou opdaag in klein dorpies, terwyl daar in Port Elizabeth 'n skare van meer as 25000 opgeteken is. Teen 16 Desember, Geloftedag, het'n totaal van 200000 Afrikaners saamgekom by Monumentkoppie en by Bloedrivier. ${ }^{110}$ Dit het hoogs emosionele, en vir sommige kommerwekkende, reaksies uitgelok, soos waargeneem deur W.H. Clarke, die Britse Hoë Kommissaris van Suid-Afrika:

TheVoortrekker celebrations evoked a degree of emotion throughout Afrikanerdom which was almost alarming in its intensity. It penetrated all classes and in certain of its manifestations resembled something akin to mass hysteria." "I

Hoewel die Eeufeestrek nie streng gesproke 'n politieke beweging was nie, was Malan se NP duidelik die begunstigde, aangesien die party se kulturele hefkrag sterker was as dié van ander ideologieë wat vir Afrikaners beskikbaar was. Grundlingh en Sappire gee te kenne dat die hoë inkoopvlak 'n belangrike populistiese fase in die ontwikkeling van Afrikanernasionalisme verteenwoordig het. Dit was opsigtelik verwyderd van die kern van ekonomiese en politieke mag en het geput uit meer sosiokulturele tipes kapitaal wat gekenmerk is deur gedeklassifiseerde, anti-intellektuele idealiserings van die verlede. Dit het ook gelei tot die stigting van koöperatiewe ondernemings soos die Reddingsdaadbond, wat spesifiek daarop gemik was om arm Afrikaners ekonomies te rehabiliteer. ${ }^{112}$

Dan O'Meara se interpretasie van Gramsci se werk oor ideologie plaas die inspanning van Afrikaner-entrepreneurs gedurende hierdie tyd in perspektief:

... (T)he general term 'ideology' encompasses at least two levels; the 'scholarly' or 'literary' on the one hand, and the 'practical' or 'popular' on the other. At the 'literary' level, ideology appears as the product of intellectuals - as a systemised and apparantly non-contradictiory set of ideas making up a coherent world-view. The 'popular' level of ideology refers to the often contradictiory forms of popular consciousness in and through which bodies of people act. ${ }^{1 / 3}$

108 Die Burger, 10 September 1938.

109 http://ancestry24.com/history-of-music-in-south-africa [besoek 20 Junie 2012].

110 Die Burger, 12-15, 17, 19-20 September, 1938.

111 Verslag deur Hoë Kommissaris W.H. Clarke, Public Record Office, Kew, Londen, Dominion Office Records 114/99, 15 Maart 1940, aangehaal in Grundlingh en Sapire, "From Feverish Festival to Repetitive Ritual?", pp. 20-21.

112 Ibid., p. 27.

113 Ibid., p. 15. 
Die etniese nasionalistiese Afrikaner-ideologie wat in die 1930's na vore gekom het, het in literêre vorm gemanifesteer as die intellektuele pogings van 'n gedeelte van die Afrikaner kleinburgery - koerantredakteurs, lede van die FAK, die Broederbond - om met die Gesuiwerde Nasionale Party te verenig. Daar was verskillende manifestasies op populêre vlak maar dit het in wese uitgeloop op die grootskaalse massa ondersteuning van Afrikaners vir die Eeufeestrek. Die belangrikheid van Afrikanerkultuur in politieke debatte in die aanloop tot die Mei 1938 verkiesing, en ook die Trek het indirek die gebied van populêre Afrikaanse musiek verhef na die politieke arena. Selfs al het die kulturele stylfigure wat die organiseerders van die eeufeestrek opgeroep het daarin geslaag om 'n hoë vlak van ondersteuning vir die saak byeen te bring, en selfs al was hulle veel meer suksesvol as ander kompeterende ideologieë, het sommige vorms van populêre Afrikaanse kultuur, veral musiek, hierdie pogings weerstaan. Froneman verken die FAK se kommer, gedurende die Trek, oor die Afrikaner se "aksiomatiese onvermoë om te sing", en gee as die mees waarskynlike verduideliking vir hierdie ongenoeë die feit dat meeste Afrikaners onbekend was met die FAK-liedjies. ${ }^{114}$ Hoewel hulle entoesiasties was om feesvieringe by te woon, het hulle meer gewilde liedjies verkies wat verafsku is in terme van die kulturele standaarde vereis deur die Trek se organiseerders. ${ }^{115}$ Die beeld wat hier na vore kom is dat, vir baie Afrikaners, die gebeure, of ten minste die aktiwiteite wat plaasgevind het na die meer ernstige toesprake en gebede, vermaak verskaf het asook 'n kans om sosiaal te verkeer. Jong mans het baarde gegroei om soos die Voortrekkers te lyk, maar hulle het nie noodwendig volledig ingekoop in die streng Calvinistiese waardes waarmee hulle voorouers dikwels geassosieer is nie. So vir die meer ernstige nasionaliste was sekere van die neweprodukte van die ontluikende kultuurpolitiek nie heeltemal so welkom nie, veral nie die populêre musiek waarop gedans en gedrink is nie. Hierdie onderskeid in kulturele voorstelling sou 'n belangrike kenmerk in populêre Afrikaanse musiek bly dwarsdeur die apartheid-era en ook daarna. Afrikaner populêre kultuur sou 'n groot deel van sy "ongemagtigde" aard behou, selfs ná nasionalisme die kultuurindustrie sou omsingel deur beheer van die SAUK, sensuur en 'n swaar-befondsde formele kunstesektor.

Omdat die SAUK voldoen het aan die beginsels van objektiewe, polities-onafhanklike nuus (die BBC-model), was die uitsaaier op hierdie stadium doelbewus apolities en ongemaklik om homself te vereenselwig met die nuwe golf van Afrikanernasionalistiese sentimente. Gedurende die Eeufeestrek is toesprake wat openlik polities was, doelbewus nie uitgesaai nie. In reaksie op Afrikanernasionaliste se besware het M.C. Botha, voorsitter van die SAUK, gesê enigiets wat moontlik van politieke belang kon wees moes van die lug af gehou word. ${ }^{116}$ 'n Goeie voorbeeld hiervan is E.C. Pienaar se toespraak, gelewer in Willowmore op Saterdag, 10 September 1938, toe die Trek daar gestop het. Die toespraak is as ongeskik geag vir die uitsending. ${ }^{117}$ Die Eeufeestrek het egter 'n kernrol gespeel om Afrikaners as 'n belangrike radio-gehoor te mobiliseer. Hoewel dekking van die Trek slegs beplan is vir die gebeure rondom die vertrek van die waens uit Kaapstad en vir sekere punte langs die roete, het die skielike vraag na dekking - na aanleiding

114 Soos voorheen genoem is die mees populêre liedjies van die dekade, veral deur kunstenaars soos Chris Blignaut en David de Lange, weggelaat uit die FAK Volksangbundel.

115 Froneman, "Seks, Ras en Boeremusiek: agter die retoriek van gebrekkige sanglus by die 1938-Voortrekkereeufees", pp. 443-444.

116 Die Burger, 12 September, 1938.

117 Ibid. 
van die sukses van die vieringe - gelei tot daaglikse uitsendings. ${ }^{118}$ Hierdie uitsendings is ingebel op landlyne en het die slegte telefoonontvangs in die plattelandse gebiede, wat die Afrikaner-vestings was, ontbloot - wat die gapings tussen die Engelse en Afrikaanse dienste beklemtoon het. Dit is belangrik om kennis te neem dat die gewildheid van die daaglikse uitsendings 'n integrale rol gespeel het, nie net om plattelandse Afrikaners as radioluisteraars te wen nie, maar ook om 'n spesifieke merk van Afrikaner kulturele identiteit uit te saai. ${ }^{119}$ Minder as 'n jaar ná die Eeufeestrek tot 'n einde gekom het, sou sy impak oorskadu word deur 'n ander gebeurtenis - die begin van die Tweede Wêreldoorlog.

118 Hayman \& Tomaselli, "Ideology and Technology in the Growth of South African Broadcasting, 1924-1971", p. 34. 119 Ibid. 


\section{HOOFSTUK DRIE}

\section{WO II, die SAUK, FAK en Boeremusiek?}

Die uitbreek van die Tweede Wêreldoorlog het verreikende politieke gevolge vir Suid-Afrika gehad. Smuts en Hertzog se koalisie het geskeur omdat Suid-Afrika oorlog teen Duitsland verklaar het. Baie Afrikaners was simpatiek teenoor Duitsland en het 'n sterk anti-Britse sentiment gekoester. Hertzog se wegbreek Volksparty het in Januarie 1940 met die Gesuiwerde Nasionale Party saamgesmelt om die Herenigde Nasionale Party (HNP) te vorm. ${ }^{1}$ In naam het hierdie samesmelting plattelandse Afrikanerkapitaal met die kleinburgery verenig, maar in werklikheid was die party diep verdeeld tussen die smelters (voormalige ondersteuners van die Verenigde Party) en gesuiwerdes (ondersteuners van die Nasionale Party (NP)). ${ }^{2}$ Voorts was die ultra-nasionalistiese Ossewabrandwag (OB), gestig in Februarie 1939 as 'n kulturele beweging in die gees van die Eeufeestrek, besig om flink te groei (met 'n geraamde lidmaatskap van tussen 300000 en 400000 Afrikaners op sy dag) omdat die Afrikaners die oorlog met Duitsland teengestaan het. ${ }^{3}$ Die OB se breë vereenselwiging met kultuurpolitiek het elemente van Afrikanernasionalistiese ideologie en kultuur gekombineer in 'n semi-gemilitariseerde identiteit. Dit sou die werkinge van die SAUK beïnvloed.

1 D. O’Meara, Volkskapitalisme: Class Capital and Ideology in the Development of Afrikaner Nationalism, 1934-1948 (Johannesburg: Ravan Press, 1983), p. 122.

2 Ibid., p. 122-125.

3 Ibid., p. 127. 
Met die begin van die oorlog is die beleid van politieke neutraliteit by die SAUK gestaak - 'n algemene praktyk onder ander buitelandse staatsuitsaaiers. Die feit dat die SAUK openlik Smuts se besluit om oorlog teen Duitsland te verklaar ondersteun het, ten spyte van menige Afrikaners se pro-Duitse sentimente, het tot spanning tussen Afrikaans- en Engelssprekende luisteraars gelei. 'n Interessante manier waarop sulke spannings in verskeie stede in Suid-Afrika gemanifesteer het (ofskoon nie'n direkte gevolg van SAUK-uitsendings nie) het bekend geword as "radiogevegte". Een koerantberig het verwys na inwoners van Kaapstad wat (onwettiglik) meegeding het met die bure om uitsendings van óf Radio Zeesen uit Duitsland óf Radio Daventry uit Engeland te ontvang. Deur hulle radio ontvanger in te stel op een van die bogenoemde seine, kon inwoners die ontvangs van daardie uitsending vir hulle bure bederf deur 'n tegniek genaamd "ossilasie". Sulke radiogevegte was simptomaties van die diep verdeeldheid onder wit Suid-Afrikaners met betrekking tot die land se deelname aan die oorlog. In haar biografie van haar oom Anton Hartman, wat later die hoof van musiek was by die SAUK, noem Mia Hartman hoe hy en sy familie na musiekuitsendings uit Duitsland geluister het, terwyl lede van die familie Adolf Hitler se Mein Kampf en Herman Goering se biografie gelees het. ${ }^{5}$ Radio Zeesen het ook 'n Afrikaanse aanbieder gehad, Erik Holm (ook bekend as 'neef' Holm), wat onder die naam Lord Haw Haw uitgesaai het. Hy het gereeld stories vertel oor gruweldade gepleeg deur die Britte gedurende die oorlog en oor hoe die Afrikaanse werkersklas gebukkend gegaan het onder Joodse kapitaliste. ${ }^{6}$ Die Duitse uitsaaier het ook die FAK genader om voorstelle vir Radio Zeesen se Afrikaanse program te kry, wat'n aanduiding is dat hulle propaganda spesifiek gerig was op Afrikaanse luisteraars. ${ }^{7}$ Die groei van Nazisme en fascisme in Europa tydens die 1930's was voorbladnuus in Afrikaanse koerante, en vele Afrikaners het hulself verheug in die opkoms van anti-Britse magte. Nie baie van hulle het die afgryslikhede voorsien wat hieruit voortgespruit het nie, en die besef na die oorlog is gereeld met verafskuwing begroet deur voormalige bewonderaars van Hitler. ${ }^{8}$

In 'n direkte reaksie op die SAUK se pro-oorlog beleid is die FAK se Radiobond in September 1940 gestig: ${ }^{9}$

Die Federasie van Afrikaanse Kultuurvereniginge het 'n tyd gelede besluit om met die oog op die doeltreffende behartiging van die Afrikaanse radiobelange, veral in huidige omstandighede van die vooropstelling van die uitsaaidiens vir politieke gebruik en propaganda teen 'n uitgesproke Afrikaanse gees en rigting in die uitsaaidiens, sy radioafdeling daadkragtiger te organiseer as wat voorheen nodig was. ${ }^{10}$

4 Die Burger, 2 September 1939.

5 M. Hartman, Anton Hartman: Dís sy storie (Groenkloof, Mia Hartman, 2003), p. 18.

6 D. Harrison, The White Tribe of Africa, South Africa in perspective (Berkeley: University of California Press, 1981), p. 126.

7 FAK Uitvoerende Raad vergaderingsagenda, 4 Julie 1939, Universiteit van die Vrystaat, Institute for Contemporary History Archives (INCH), FAK Versameling, PV 125 1/3/1/1/1/. 
Die Radiobond van die FAK is formeel opdrag gegee om bystand te verleen aan die Radioraad van die SAUK, wat in Augustus 1936 gestig is om gehoor te gee aan versoeke van die Afrikaanse luisteraarspubliek. Verder sou die Radiobond hulself beywer om meer Afrikaners na die radio te bring, waardeur hulle die SAUK verder onder druk sou sit, want tot op daardie tydstip is die FAK se versoeke vir sterkter Afrikaanse senders en ander sake rakende programinhoud teengestaan. ${ }^{11}$ Aan die stuur van die Radiobond was Advokaat J.F. (Kowie) Marais, 'n voormalige programopsteller van die SAUK se Afrikaanse diens (en die persoon wat 'n jong Anton Hartman sy eerste pos by die SAUK in 1939 aangebied het). ${ }^{12}$ Hy is in September 1940 ontslaan van die SAUK weens groeiende spanning tussen die Korporasie se Afrikaans- en Engelssprekende personeellede. ${ }^{13}$ In daardie selfde jaar het Marais aangesluit by die Stormjaers, die Ossewabrandwag se para-militêre vleuel, en is in 1941 geïnterneer, net om te ontsnap en weer gevang te word in 1942. Hy is daarna by Koffiefontein geïnterneer saam met 'n jong B.J. Vorster en die FAK se Stephen Eyssen. ${ }^{14}$ Marais se geluk het ná die Oorlog gedraai, en hy het later Direkteur-Generaal van die SAUK geword..$^{15}$ Die manier waarop Afrikaanse personeellede by die SAUK behandel is aan die begin van die Oorlog het die FAK oorgenoeg skietgoed gegee. 'n Omsendbrief gedateer 30 September 1940 bevat 'n emosionele beskrywing van Marais se ontslag asook 'n verwysing na 'n insident by die SAUK wat in die eerste week van die Oorlog plaasgevind het waartydens daar 'n poging was om Afrikaanse personeellede met geweld van die stasie te verwyder en 'n einde te maak aan alle Afrikaanse uitsendings. ${ }^{16}$ 'n Ander FAK omsendbrief gedateer 26 November 1940 verwys na 'n insident in Desember 1939 waartydens Afrikaanse personeellede daarvan beskuldig is dat hulle die Korporasie se nuwe pro-Oorlog beleid oortree het, ten spyte van die feit dat hulle nie ingelig is van enige beleidsveranderinge nie. ${ }^{17}$ Marais se ideologiese posisie as hoof van die FAK se Radiobond, terwyl hy gelykertyd 'n Stormjaer was en vir alle praktiese doeleindes 'n anti-regering saboteur, maak dit ongetwyfeld 'n verregse stelling. Bronne van die teenoorgestelde sy van die politieke spektrum bevestig ten minste die spanning tussen personeellede:

Although no one liked to admit or talk about it, there was very close to the surface an antagonism between Afrikaans and English and a definite belligerence on the part of an Afrikaans speaking group, engendered by a so-called inferiority complex. The English speaking section - rather stupidly condescending at times - blandly ignored the situation but gradually key administrative posts were filled by Afrikaans speaking and/or sypathetic individuals. It should be remembered that the Smuts Government during the war contained many Afrikaners and that there was a strong dedicated anti-British group ... So that while almost all English-speaking people innocently stood by, the ground was thoroughly prepared for an Afrikaner take-over in Broadcasting. ${ }^{18}$

11 FAK omsendbrief, 30 September, 1940, INCH, FAK Collection, PV 2/3/1/1/1.

12 Hartman, Anton Hartman, p. 21.

13 Ibid.

14 Harrison, The White Tribe of Africa, pp. 131-132.

15 Hartman, Anton Hartman, p. 21.

16 INCH, FAK Versameling, PV 2/3/1/1/1.

17 Ibid.

18 Anonieme radio-akteur in 'n persoonlike brief gedateer 25 Junie 1968 aan P.B. Orlik, aangehaal in P.B. Orlik, in S. Head (red.), Broadcasting in Africa: A Continental Survey of Radio and Television (Philadelphia: Temple University Press, 1974), p. 142. 
A verdere en redelik ironiese gevolg van die Oorlog was dat meer en meer anti-oorlog Afrikaanse werknemers die poste van hulle Engelse kollegas wat vrywillig diensplig gaan doen het sou begin oorneem. ${ }^{19}$ In 'n sekere sin was die SAUK 'n mikrokosmos wat 'n wyer Suid-Afrikaanse samelewing verteenwoordig het. Piet Meyer, wat 'n invloedryke rolspeler sou word in die geskiedenis van Suid-Afrika se uitsaaiwese, was altyd indirek betrokke by die korrespondensie van die FAK gedurende die vroeë oorlogsjare. Gedurende die Oorlog het Meyer se betrokkenheid by die Ossewabrandwag en die feit dat hy sy ekstreme politiese sienings graag aan die groot klok gehang het sy posisie op die uitvoerende rade van 'n aantal Afrikaner kulturele organisasies benadeel. Hy is in 1943 geforseer om te bedank as FAK en Broederbond raadslid (hy het reeds in 1932 aangesluit by laasgenoemde). ${ }^{20}$ Die FAK se Radiobond het al teen hierdie tyd nie regtig meer gefunksioneer nie.

\section{Ná die 0orlog}

Voor 1939 is byna alle musiek wat plaaslik opgeneem is in die buiteland gedruk maar vernislaktekorte en beperkte verskeping tydens die oorlog het gelei tot 'n toename in plate wat plaaslik gedruk is, ofskoon van laer gehalte. ${ }^{21}$ Die post-oorlog jare - veral na 1948, toe buitelandse meesteropnames gebruik is om plaaslike albums te druk - het 'n stewige groeitydperk vir die plaaslike plaatbedryf ingelui. ${ }^{22}$ Wat Afrikaanse musiek betref het die SAUK geleidelik meer invloedryk geword in die plaaslike musiekbedryf. Tot en met 1948 sou sommige kunstenaars blootstelling op die radio kry - óf deur regstreekse optredes of hulle plate wat gespeel word - maar die impak van Afrikaanse radio uitsendings was steeds beperk. Danksy finansiële moeilikheid wat verband gehou het met ondoeltreffende lisensiëringstrategieë is die Schoch Kommissie in 1946 aangestel om die moontlikheid te ondersoek om 'n kommersiële stasie in te bring naas die "A" (Engelse) en "B" (Afrikaanse) dienste. Die bedoeling was om die fondse wat hierdie derde stasie sou inbring te gebruik om die kapasiteit te vergroot van die Afrikaanse senders wat nog afgesteek het teen die Engelse diens s'n. Tot en met die 1950's was radioseine nie voldoende in die plattelandse areas waar meeste Afrikaners gewoon het nie. Die invloed van radio was dus beperk tot die stede, waar die armste Afrikaners gewoon het wat nie radio ontvangers kon bekostig of hulle lisensies betaal nie. Dit het Afrikaanse radio beperk in terme van die bemarking van nuwe Afrikaanse musiekvrystellings. In 1948, toe die NP onverwags die verkiesing wen, is 'n nuwe raad aangestel deur die nuwe regering, wat beteken het dat die sleutelposte in die SAUK nou deur nasionaliste beklee is. Smuts se regering was gedeeltelik verantwoordelik vir hierdie stand van sake, aangesien hulle nie verwag het om die verkiesing te verloor nie en geen voorsiening gemak het om die aanstellings van die vorige raadslede - meestal opponente van die nasionaliste - te verleng nie. ${ }^{23}$ Desnieteenstaande was die nuwe direkteur-generaal, Gideon Roos, 'n groot voorstaander van die relatiewe objektiwiteit

19 Ibid.

20 Harrison, The White Tribe of Africa, p. 40.

21 J.P. Malan (red.), Die Suid-Afrikaanse Musiek Ensiklopedie Vol. 1, (Kaapstad: Oxford University Press, 1986), p. 354.

22 Ibid.

23 G. Hayman en R. Tomaselli, "Ideology and Technology in the Growth of South African Broadcasting, 1924-1971", in R. Tomaselli, K. Tomaselli \& J. Muller (reds.), Currents of Power: State Broadcasting in South Africa (Kaapstad: Anthropos, 1989), p. 77. 
wat deur die BBC gebruik is. ${ }^{24}$ Gevolglik was verandering aan SAUK-beleid traag na 1948, en dit was eers in 1959, met die aanstelling van Piet Meyer as voorsitter van die raad, dat die uitsaaier alle skyn van politieke neutraliteit verloor het. Hierdie politieke oorname van die SAUK was die begin van 'n era van voldoening aan staatsideologie.

\section{Die SAUK, die FAK en Boeremusiek}

Met tyd kon Afrikaner intellektuele 'n etniese, rasse- en kulturele identiteit meer duidelik verwoord. Die FAK het kommissies tot stand gebring wat sou fokus op sosiale en kulturele sake, insluitend opvoeding, welsyn (deur organisasies soos die Reddingsdaadbond), rassebeleid, musiek, radio, film, teater, ekonomie, vryetydsbesteding en volksfeeste. ${ }^{25}$ In 1941 het die FAK die Musiekkomitee gestig: “ ... omdat die FAK-bestuur dit noodsaaklik ag dat daar meer gedoen moet word vir die bekendstelling van Afrikaanse musiek." ${ }^{26}$ Dit was deel van 'n wyer strategie om kulturele selfgenoegsaamheid ${ }^{27}$ te vestig wat 'n komplekse stel inisiatiewe teweeggebring het wat deur E.C. Pienaar opgesom word in Triomf van die Afrikaanse Taal:

Nie net ons taal moet gesuiwer word van vreemde elemente nie, nie net ons letterkunde moet opgebou en uitgebou word nie, nie net ons leeslus en waarderingsvermoë moet aangekweek word nie, nie net ons eie lied en eie musiek moet geskep en beoefen word nie ..., maar die huise waarin ons woon, die meubels wat ons gebruik, die prente aan ons mure, die boeke op ons rakke, die benaming van ons plekke - kortom, ons hele uitsig en gedagtegang en geestesgesteldheid moet 'n eie inheems-Afrikaanse gees vertolk, sodat die vreemdeling wat hier kom, geen oomblik in twyfel sal verkeer dat hy dit met 'n Afrikaner te doen het nie. Ons nasieskap moet ons hoogste nasietrots wees! ${ }^{28}$

Hierdie toon 'n sterk begeerte om "eiewaarde" as 'n volk te bereik. ${ }^{29}$ Die sfeer van Afrikaanse musiek was ingesluit by hierdie kulturele selfgenoegsaamheid, en lede van die Musiekkomitee het gereeld hulle sorg uitgespreek oor lae-gehalte Afrikaanse musiek en terselfdertyd hulself beywer om die komposisie van Afrikaanse musiek van hoë artistieke standaarde te stimuleer. Hierdie beleid is deur G.G. Cillié saamgevat in sy intreerede nadat hy by die FAK se uitvoerende raad aangesluit het in 1946:

Ek verkondig nie enige nasionalisme op die gebied van die musiek nie, maar dit is nou eenmaal so dat geen komponis van Palestina en Bach tot Sibelius, sy beste gelewer het tensy hy getrou gebly het aan sy volk en gedurig gebruik gemaak het van sy eie volk se kultuurgoed nie. ${ }^{30}$

24 Ibid.

25 Notule van FAK raadsvergaderinge, 1 Februarie 1946-14 November 1946, INCH, FAK Versameling, PV 125 $1 / 3 / 1 / 1 / 2$.

26 Federasie van Afrikaanse Kultuurvereniginge, FAK Silwerjubileum 1929-1954, (Johannesburg: FAK, 1954), p. 49.

27 Giliomee, Die Afrikaners, p. 402.

28 Die Triomf van Afrikaans: Historiese Oorsig van die wording, ontwikkeling, Skriftelike Gebruik en geleidelike erkenning van ons Taal (Kaapstad, Nasionale Pers, 1943), pp. 380-381.

29 Soos N.P van Wyk Louw dit stel in Versamelde Werke, angehaal in Giliomee, Die Afrikaners, p. 402.

30 Referaat gelewer by die FAK Volkskongres, Stellenbosch, 1946, US Biblioteekargief, G.G. Cilliers Versameling, MS 210, p. 74. 


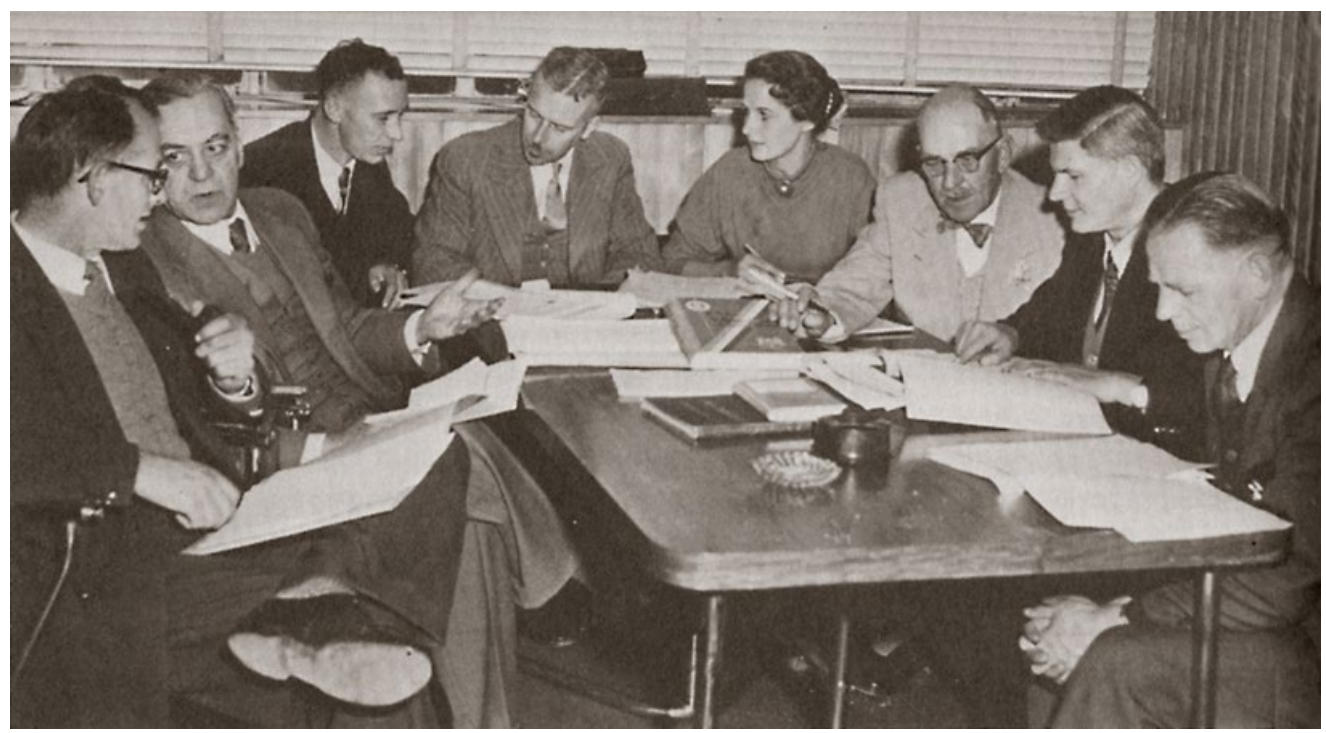

FAK Musiekomitee in 1956. Van links na regs: Dirkie de Villiers, Stephen Eyssen, Tommy Meyer (assistent sekretaris), G.G. Cilliè, J. Heynecke (notule-nemer), I.M. Lombard, Anton Hartman en Hartman van Niekerk (algemene sekretaris). ${ }^{31}$

Ironies genoeg was die FAK se strewe om Afrikaanse komposisies van sulke hoë standaarde te bevorder eintlik pogings om 'n westerse klassieke, maar ook uitheemse, estetika te vestig in die kulturele ryk van Afrikaanse musiek. Dit het die wesenlike teenstrydigheid van die "wettiging" van Afrikanernasionalistiese kultuur in sy geheel weerspieël: die konflik tussen die vestiging van 'n plaaslik-ontwikkelde weergawe van "hoë Europese" kultuur en die verontagsaming, of ondermyning, van meer organiese plaaslik-ontwikkelde kultuur.

Ideologies is hulle gelei deur Christelik-nasionale ideale wat gedeel is deur ander organisasies soos die Nederduits-Gereformeerde Kerk (NGK) en Malan se NP. Aktiwiteite wat teen hulle paternalistiese posisie teenoor die volk ingedruis het is ontmoedig (hondewedrenne ${ }^{32}$, boeremusiek), terwyl die elites by volkskongresse toesprake gelewer het oor 'n verskeidenheid onderwerpe, insluitende kulturele "bedreigings" uit die buiteland wat besig was om die Afrikaner se identiteit weg te vreet. Hierdie bedreigings kon kom in populêre musikale vorms soos jazz en selfs evangeliese kerkliedjies. Nog 'n uittreksel uit G.G. Cillié toespraak by die FAK se 1946 Volkskongres dien as 'n nuttige voorbeeld:

Ons mag nie toelaat dat ons kinders Sondae en by godsdiens in ons skole Engelse 'hymns' en Amerikaanse 'Revival'-liedjies sing nie en gedurende die week jazz deuntjies fluit wat hul oor die radio of in die bioskoop gehoor het nie..$^{33}$

31 Beskikbaar by http:// www.wikiwand.com/af/Gawie_Cilli\%C3\%A9 [besoek 20 Maart 2017]. I.M. Lombarsd was die sekretaris van die Broederbond en FAK en het ook op die plaaslike raadgewersraad van die SAUK van Johannesburg gedien.

32 Die Burger, 10 September 1938.

33 Referaat gelewer by die FAK Volkskongres, Stellenbosch, 1946, US Biblioteekargief, G.G. Cilliers Versameling, MS 210, p. 74.a.. 
Hierdie was een van die vroeër besware wat aangeteken is teen die kulturele invloed van ingevoerde musiek op die Afrikanerjeug. 'n Besonder sensitiewe aangeleentheid was die verskil tussen die smake van werkersklas Afrikaners en die Afrikaner elite, soos betreur deur die FAK se Dirkie de Villiers:

Stap egter 'n musiekwinkel binne: die rakke is vol vervlakkende, sogenoemde "Boeremusiek"-liedjies; maar kan u bv. instap en, sê nou maar, Hartman se "Kom vanaand in my Drome" van die rak af koop? Dieselfde wanverhouding geld by Suid-Afrikaans-vervaardigde grammofoonplate (hoewel die Afrikaner nie hier al die skuld dra nie, aangesien die groot platemaatskappye in Engelssprekendes se hande is). Die maatskappye buit die onkritiese smaak van 'n groot deel van die Afrikaanse bevolking uit deur iedere maand 'n ononderbroke stroom van opnames die land in te stuur - opnames wat vir sover dit die musiekgehalte betref laag by die grond is. ${ }^{34}$

\section{Die vrae rondom boeremusiek en klas}

Die verband tussen boeremusiek en klas roep om nadere ondersoek, veral op die manier wat dit tussen die 1930's en die 1950's ontwikkel het. Die oorkoepelende term boeremusiek het verskillende style ingesluit wat beide die same- en uiteenlopende aspekte van die Afrikaner-samelewing verteenwoordig het. Froneman onderskei tussen drie verskillende tipes boereorkeste tydens hierdie era wat "n wye verskeidenheid instrumentele toonsettings en optrede-praktyke" beoefen het. ${ }^{35}$ Die eerste tipe, waarvan die Stellenbosch Boereorkes die mees bekende was, was 'n groot orkes (meer as 30 musikante met 'n verskeidenheid instrumente) wat spesifiek geskep is as "propaganda-media" vir die NP in die aanloop tot die 1938 Trek-vieringe en daarna. ${ }^{36}$ Hulle het gewoonlik variété-konserte opgevoer waar daar nie gedans is nie. Die tweede tipe sluit in die professionele musiekgroepe wat betrokke was by regstreekse uitsendings en wat deur die land getoer het en by danspartytjies opgetree het. Hulle repertoires het moontlik boeremusiek bevat, maar dit was ondergeskik aan meer kommersiële jazz-klanke en dansmusiek. Hendrik Susan se orkes met hulle ligte Afrikaanse musiek val in hierdie kategorie. Die laaste tipe het effens vroeër as die ander verskyn met die aanvanklike vastrap-boeremusiek-opnames van die 1930's deur groepe soos Die Vyf Vastrappers, David de Lange se "Die Naglopers" en Die Vier Transvalers. Hierdie groepe was die mees verteenwoordigend van tradisionele musiek van boeredanse en vieringe. Hulle was dikwels:

... financially strapped, working-class musicians with bad habits and a plain disregard for the growing racial ideology of the day, they did not conform to establishment Afrikaner cultural ideals. ${ }^{37}$

Klas elemente van die Afrikaner-samelewing gedurende hierdie tyd was 'n belangrike belemmering vir die vorming van nuwe nasionalistiese identiteite. O’Meara se evaluering van Afrikaner klasdinamika tussen 1934 en 1948 het die tekortkominge uitgewys van etnies

34 D. de Villiers, "Die Afrikaner se Musiekprestasies die Afgelope Kwarteeu”, referaat gelewer by die FAK Silwerjubileumkongres, Bloemfontein, 29 September-3 Oktober 1954.

35 Froneman, "Pleasure beyond the call of duty", pp. 96-97, vertaal uit die oorspronklike.

36 Ibid.

37 Ibid., p. , 97. 
dinamiese verduidelikings vir die opkoms van die Afrikanernasionalistiese mitologie. ${ }^{38} \mathrm{Hy}$ maak die belangrike waarneming dat Afrikanernasionalisme hoogs gedifferensieërd was en slegs een van 'n aantal politieke en ideologiese vorms van verset en voorts dat dit voortgespruit het uit die bestrede ontwikkeling van kapitalisme in Suid-Afrika. ${ }^{39}$ Veral die spesifieke soort Afrikanernasionalisme wat prominent geraak het ná 1934 het gespruit uit kleinburgerlike groepe se ambisies om toegang tot kommersiële en industriële kapitaal te verkry deur'n mengsel van organisasievaardighede, ideologie en politieke invloed te gebruik om ondersteuning van Afrikaanssprekers van alle klasse te mobiliseer. ${ }^{40}$ Soos Hyslop later uitwys verskaf hierdie benadering 'n deurslaggewende begrip van Afrikanernasionalisme, omdat dit krities is van die aanname dat Afrikaners 'n ongedifferensieerde, monolitiese etniese groep is. Die etniese identifikasie wat gedurende die 1930's ontstaan het was'n konstruksie wat groot verskuiwingslyne van klas, geslag en belangstelling moes weerstaan, en bedek. ${ }^{41}$

Vir Rob Allingham was tradisionele boeremusiek se gehore ongetwyfeld boere en die stedelike werkersklas wat verskil het van die Europese smake van die middelkas Afrikanernasionalisme. Laasgenoemde groep kon egter die meer tradisionele liedjies aanvaar as outentieke volkskultuur, mits dit ernstig genoeg aangebied is. ${ }^{42}$ Met ander woorde, ligte Afrikaanse musiek was die gereinigde, goedgekeurde weergawe van werkersklas volksmusiek, wat aan die smaak van middelklas Afrikanernasionaliste voldoen het. In Song Safari maak Ralph Trewhela'n interessante punt wat aansluit by die klasverdeling van Afrikaanse gehore. In 1949 is Susan genader deur die vervaardiger Pierre de Wet om deel te wees van die Afrikaanse rolprent Kom saam vanaand. $\mathrm{Na}$ aanleiding van die sukses van die fliek het Susan se gehore begin verander. Hy was vroeër gereken bloot as 'n boeremusikant, maar ná Kom saam vanaand was daar skielik dokters, regslui en akademici in die gehoor. ${ }^{43}$ Dit dui daarop dat die prestige wat gekom het met filmblootstelling Hendrik Susan se optrede verhef het om die middelklas in te sluit. Froneman reken die omstandighede was egter veel meer kompleks. ${ }^{44} \mathrm{Om}$ die waarheid te sê wil dit voorkom asof die ligte Afrikaanse musiek van mense soos Susan gereeld deur die kulturele elite gekritiseer is. Aan die een kant het dit byval gevind by die Afrikanernasionaliste se strewe na Europese standaarde, maar daar was 'n algehele gebrek aan konsensus oor die kulturele waarde daarvan. Oor die algemeen is dit geag as 'n uitheemse invloed op regte boeremusiek, terwyl sommige dit as 'hotnotsmusiek' beskryf het, inspelend op rasse stereotipes. Uiteindelik stel Froneman voor dat baie Afrikaners net nie die gebruik van "Hawaiïese kitare, gejodel en dies meer" kon vereenselwig met "regte" boeremusiek nie. ${ }^{45}$ Die nuwe klanke het ontstaan naas die moderne, jazzerige ligte Afrikaanse musiek op 'n tyd toe boeremusiek gekommersialiseerd geraak het, wat

38 D. O'Meara, Volkskapitalisme: Class, Capital and Ideology in the Development of Afrikaner Nationalism 1934-1948 (Johannesburg: Ravan Press: 1983), pp. 4-11.

39 Ibid., p. 16.

40 Ibid.

41 J. Hyslop, "Problems of Explanation in the Study of Afrikaner Nationalism: A Case Study of the West Rand", Journal of South African Studies, 22:3 (1996), p. 373.

42 Allingham, "South Africa - Popular Music: Nation of Voice", p. 651, aangehaal in Froneman, Pleasure beyond the call of duty, p. 122, vertaal uit die oorspronklike.

43 R. Trewhela, Song Safari: A journey through light music in South Africa (Johannesburg: Limelight Press, 1982), p. 128, vertaal uit die oorspronklike.

44 Froneman, "Pleasure beyond the call of duty", p. 122.

45 Ibid., p. 123, vertaal uit die oorspronklike. 
'n deeltjie byvoeg by Allingham se "stedelik/landelik" en "polities onskuldig/ polities bewus" teenstellings. Jazz se invloed op tradisionele boeremusiek het 'n belangrike kwessie geword wat die FAK se Musiekkomitee, sowel as die SABC gekommer het van die vroeë 1940's tot die laat 1950's:

Before the advent of broadcasting nothing much was done to trace, systematise and reserve the folk tunes scattered over the wide expances of South Africa. The SABC considers it an important part of its task to preserve this cultural heritage of the country and has already succeeded to a not inconsiderable extent in making the folk tunes a small but important part of its daily programme output. At least a quarter of an hour per day is devoted to this music which is broadcast under the title of Boeremusiek, which, literally translated, means rural music or the music of the farmer. During recent years this music has not escaped the influence of modern jazz and a few years ago the SABC initiated a country-wide organised search for all the remaining folk tunes with the idea of preserving them in unadulterated form, in the central library. ${ }^{46}$

Die oorgang van skandelike lawwighede na 'n deel van Afrikaner-volksoorlewing het beteken dat boeremusiek nou geag is as deel van 'n kulturele erfenis. Hierdie erfenis het al hoe meer heilig geword namate Afrikanergeskiedenis herskryf is deur kulturele entrepreneurs op 'n tydstip wat die NP se magsgreep besig was om te verstewig. Dit was nie 'n skielike oorgang nie. Die FAK se Musiekkomitee het in 1947 'n samekoms vir boereorkes-entoesieaste en folk-sang beplan. Dit sou in Durban gehou word van 30 Junie tot 11 Julie van daardie jaar. ${ }^{47}$ Die SAUK, wat gretig was om boeremusiek te bemark, het tot 30 boereorkeste geborg om oorspronklike Afrikaanse musiek te maak, eerder as liedjies wat deur jazz beïnvloed is. Deel van die SAUK se "taak om hierdie kulturele erfenis te bewaar" was 'n veldtog wat in 1950 geloods is om tradisionele Afrikaanse boeremusiek te versamel..$^{48}$ Die eindproduk is gereeld uitgesaai op programme soos Uit die jaar vroeg en is - ietwat ironies - gespeel deur die orkeste van Hendrik Susan en Hansie van Loggerenberg. ${ }^{49}$ Op hierdie stadium was daar 'n hegter verhouding tussen die FAK en die SAUK, en Anton Hartman was invloedryk in beide organisies. ${ }^{50}$ Vir baie jare was Hartman die mees prominente musiek-ideoloog onder die Afrikaner kulturele elite. Hy het in 1939 by die SAUK begin as 'n musieksamesteller, en vanweë sy posisie was hy baie invloedryk in terme van wat gespeel is en wat nie. Hy is as 'n klassieke musiek dirigent in Europa opgelei, en op 'n manier het dit hom onderskei van die kommersiële wêreld van Afrikaanse musiek. In hierdie sin het hy die mening gedeel dat Afrikaans moes voldoen aan 'n hoë Wes-Europese estetika. Hy het ook die SAUK se orkes gedirigeer en was lank'n lid van die FAK se Musiekkomitee, en vanaf 1946 het hy verskeie praatjies op die radio gegee oor Afrikaanse folk-liedjies en boeremusiek.

46 G. Roos, Algemene jaarverslag gelewer aan die Vyfde Jaarlikse Konferensie van die International Folk Music Council, 14-17 Julie 1952, Journal of the International Folk Music Council, 5:3 (1953), p. 9.

47 FAK Musiekkomiteevergadering, 8 Februarie 1947, US Biblioteekargief, G.G. Cilliers Versameling, MS 210, p. 74.

48 Fronemann, "Songcatcher of the Groot Maricho", p. 67, vertaal uit die oorspronklike.

49 P.J. van der Walt, "Die S.A.U.K., met spesiale verwysings na sy verhouding tot die staat”, ongepubliseerde M.A proefskrif, 1973, Universiteit van Potchefstroom, p. 192.

50 Hartman het in 1939 by die SAUK begin werk as 'n samesteller van musiekprogramme. Hy het ook in 1944 aangesluit by die Musiekkomitee. Dit is onduidelik wanneer hy 'n lid van die Broederbond geword het, maar dit was waarskynlik eers later. 
Teen 1953 was daar steeds geen sekerheid onder die FAK en SAUK se uitvoerende raadslede oor die betekenis van boereorkes en boeremusiek nie. Die oënskynlike probleem was dat die SAUK versoeke ontvang het van Afrikaanse radioluisteraars vir meer boeremusiek. ${ }^{51}$ Van der Walt stel dat daar konstante onsekerheid was by die SAUK oor hoe om verskillende vorms van ligte musiek te klassifiseer, en hoe om te onderskei tussen "ligte" en "ernstige" musiek. Boeremusiek sou soms onder "dansmusiek" val, en ander kere sou dit apart gelys word. ${ }^{52}$ 'n Analise van die SAUK se Afrikaanse musiekprogramme tussen 1951 en 1954 dui op 'n voorkeur vir boeremusiek en ander ligte Afrikaanse musiek, terwyl ligte orrel- en klaviermusiek en moderne dansmusiek van Amerika en Brittanje die mees populêre genres was vir Engelse luisteraars. ${ }^{53}$ Platemaatskappye het sake nog meer deurmekaar gekrap omdat hulle die titel boeremusiek gebruik het om plate te verkoop, al was dit nie tegnies gesproke boeremusiek nie. Nico Carstens het sy hele loopbaan deur weggeskram van die term boeremusiek, hoewel vele van sy topverkopers as sulks vrygestel is. ${ }^{54}$ Een van sy albums, vrygestel in die VSA in 1957, is as "Oorspronklike Suid-Afrikaanse Boeremusiek" bemark. Dit is duidelik dat dit in hierdie geval slegs gebruik is as 'n bemarkingsfoefie vir Amerikaanse gehore wat nuuskierig was oor volksmusiek van ander lande. Die Suid-Afrikaanse plaat se titel was "Volksliedjies".

Met die verwysing nie net na klas nie, maar ook na ras mak Anton Hartman die volgende opmerking oor die kreoolse oorsprong van boeremusiek:

Net so het daar by ons die begrip 'hotnotsmusiek' ontstaan. Die woord is gebruik om feitlik alle soorte inheemse volksmusiek aan te dui. En die rede? Sommer vroeg in die bestaan van die blanke samelewing in S.A. is ontdek dat sommige slawe en kleurlinge 'n gebore aanleg vir musiek het, en gou-gou was hulle die mense wat die blankes se musiek op danspartytjies gespeel het. Die blankes het dit maar aan hulle oorgelaat, net soos hy sekere soort werk aan hulle oorgelaat het, en metteryd is daar gepraat van 'hotnotsmusiek' ... Die musiek is vir so lank en op so 'n groot skaal deur gekleurdes beoefen, dat hulle ook hulle stempel daarop afgedruk het. Maar dit was tog in die kern Afrikaanse volksmusiek en toe die walle van vooroordeel eers gebreek is, het dit onkeerbaar uit ons stede en dorpe en ver verlate vlaktes opgeklink. ${ }^{55}$

Hoewel die verwysing na die "walle van vooroordeel" dubbelsinnig is, en waarskynlik 'n verwysing is na die aanvaarding van boeremusiek as 'n regmatige deel van die Afrikaner se erfenis, lê die belangrikheid van hierdie stelling in die erkenning van die gemengde-ras oorsprong van wat gekonstrueer is as 'n erkende Afrikaanse volksmusiek. Ook van betekenis is Hartman se stelling dat, hoewel die musiek meestal gespeel is deur "mense van kleur" dit in wese Afrikaner volksmusiek was wat uitsluitlik aan witmense behoort het. Bruinmense se deelname in hierdie arena is aanvaar solank as wat dit ingepas het by die hierargie van ras - en klas - wat deur

51 FAK notule van uitvoerende komiteevergadering 25 April 1953, Biblioteekargief, G.G. Cilliers Versameling, MS $210,74$.

52 Van der Walt, “Die S.A.U.K., met spesiale verwysings na sy verhouding tot die staat”, pp. 193-194.

53 Ibid., p. 197.

54 S.H.R. Louw, "Nico Carstens as innoveerder van Suid-Afrikaanse Populêre Musiek”, MMus Tesis, Universeit van Vrystaat.)

55 A. Hartman, "Waarheen boeremusiek?" Dagbreek en Sondagnuus, 13 Februarie 1995, aangehaal in W. Froneman, Pleasure Beyond the Call of Duty, p. 49. 
witmense gedomineer is. Die feit dat Hartman in wese die opvoer van Afrikaanse volksmusiek onder bruin arbeiders plaas is ook noemenswaardig. 'n Aantal van die bekendste Afrikaanse musikante van die middel twintigste eeu - onder andere Nico Carstens - het erkenning gegee aan bruin plaasarbeiders se invloed op hulle eie musiek.

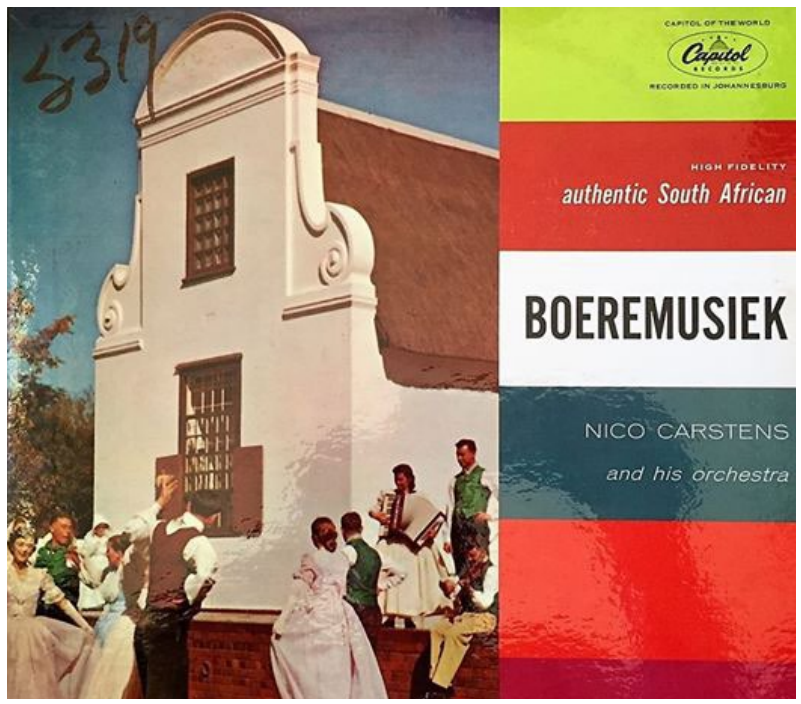

'n Amerikaanse vrystelling van Carstens se musiek (Capitol Records, TI0075, 1957). ${ }^{56}$

Teen hierdie agtergrond gesien is die FAK en die SAUK se regverdiging van boeremusiek ietwat eienaardig. Dit mag 'n pragmatiese reaksie gewees het op gehoorversoeke aan die SAUK, of 'n beskermende strategie teen die groeiende stilistiese invloed van jazz - begin deur kunstenaars soos Hendrik Susan wat boeremusiek in die eerste plek aangepas het vir radio. Baie jare later in 1962, het Hartman 'n lesing gegee oor uitheemse invloede in Afrikaanse musiek en in wese die verwarring aangespreek oor "tradisionele" boeremusiek en "ligte Afrikaanse musiek". Hy het gemeen dat boeremusiek gesien moet word as ware Afrikaanse tradisionele musiek, en dat daar gewak moet word teen moderne invloede van buite op hierdie genre, veral die invloed van jazz. Dit was moontlik 'n aanduiding van groter vrese wat gedeel is deur 'n aantal van die Afrikaner elite - verengelsing en die invloed van die buitewêreld - dinge wat die volksvaders ten alle koste wou vermy. ${ }^{57}$ Teen die 1970 's is die verifikasieproses klaarblyklik voltooi:

U weet 'n kwarteeu gelede was "O Brandewyn laat my staan" 'n "lelike" lied en mag ons dit nie gesing het nie. Maar dié snobisme skuur af, en met die jare ontwikkel so 'n lied tot 'n "antieke" werk. Uit sentimentaliteit, of liefde vir ons erfstukke, word dit eindelik goed genoeg geag vir ons kollege- en universiteitskore. ${ }^{58}$

56 Met vergunning van Tertius Louw.

57 Sien G.G. Cilliers se toespraak, US Biblioteekargief, G.G.Cilliers Versameling, MS 210, p. 74; ook US Biblioteekargief, H.B. Thom Versameling, MS 191.FAK.1.k (167).

58 C. Rudolp, "Die Afrikaner se plek en taak in die beofening van Ligte Musiek", Handhaaf, Augustus 1972, pp. 27-32. 
Hierdie aanvaarding was 'n bekragtiging gebaseer op die heruitvinding van 'n "oorspronklike" Afrikaner volkskultuur wat die rasse-eksklusiewe vereistes van die nuwe nasionalisme gepas het. Vir hierdie rede het dit deel geword van die "literêre" of "gemagtigde" kultuur van Afrikanernasionalistiese ideologie, terwyl die gebruik daarvan onder werkersklas Afrikaners "populêr" of "ongematigd" gebly het. Hoewel mens graag die FAK en SAUK se snobisme teenoor ligte Afrikaanse musiek sou wou sien as 'n bewys daarvan dat hulle die genre as nadelig beskou het vir die volk se kulturele welstand, moet mens nie vergeet dat die smaakverskille tussen radio-luisteraars oor 'n wye sosiale spektrum strek nie. Dit is seker een van die grootste uitdagings vir die meeste radio-netwerke wêreldwyd. Dit is veral waar van die BBC in Brittanje, wie se model deur die SAUK gevolg is gedurende sy eerste twee dekades. Radio programme het deels gespeel wat gewild was onder 'n breë groep luisteraars, maar het ook 'n opvoedkundige rol gespeel in die ontwikkeling van musieksmaak. Die uitdaging was om balans te handhaaf tussen die twee strategieë. Die volgende verklaring gemaak in 1957 deur die SAUK se direkteur-generaal Gideon Roos getuig daarvan:

Toe ek sowat 24 jaar gelede tot die uitsaaidiens toegetree het, was die gehalte van die merendeel versoeke maar bedroewend: "Die Boeliebiefblik", "Die Donkie" is 'n Wonderlike Ding", "Die Naglamp van Oom Piet", ens. Luister maar self vandag, en u sal merk hoe baie versoeke kom uit die klassieke repertoire. Die radio het die algemene musieksmaak in ons land geweldig verbeter en die belangstelling in musiek geweldig laat groei..$^{59}$

Die debatte oor boeremusiek onder lede van die FAK se Musiekkomitee en die SAUK is oorskadu deur ander ontwikkelinge op die plaaslike musiektoneel. Een so 'n belangrike ontwikkeling was Gallo se aanleg van 'n plaaslike plaatdrukkery in 1949, wat beteken het dat plate nou volledig in Suid-Afrika gemaak kon word. In die eerste twee maande alleen is daar meer as 500000 plate gedruk. Dit het gelei tot 'n proliferasie van plaaslike musiekopnames. ${ }^{60}$ Dinge was ook besig om te verander by die SAUK.

\section{Kommersiële Afrikaanse musiek, Springbok Radio en politiek gedurende die 1950's}

Ná die Schoch Kommissie het die koms van die SAUK se kommersiële radiostasie, Springbok Radio, op 1 Mei 1950 'n beduidende invloed gehad op die manier wat kommersiële musiek aan die Suid-Afrikaanse publiek uitgesaai is. Vroeër het die Engelse en Afrikaanse dienste uiteenlopende programme aangebied wat bestaan het uit kommersiële musiek (insluitende boeremusiek), sowel as klassieke musiek en ander genres. Maar met 'n toegewyde kommersiële stasie wat advertensies verkoop het en vir dié rede moes verseker dat programme in voeling bly met die smake van luisteraars, het die dinamika van radio egter verander. Die toegewyde Engelse en Afrikaanse uitsendings het steeds aangehou met hulle tradisionele programme, terwyl die nuwe kommersiële stasie aan die smake van die massas voorsien het.

Springbok Radio het kommersiële pop- en rock-liedjies gespeel en het die amptelike Suid-Afrikaanse weeklikse trefferparade aangebied. Plaaslike Engelse, en tot 'n mindere mate Afrikaanse, musiek is dikwels gespeel, met 30 Afrikaanse liedjies wat die trefferparade gehaal

59 G. Roos, Die uitsaaiwese in diens van ons Samelewing (Johannesburg: SAUK, 1957), p. 24.

60 R. Trewhela, Song Safari, p. 45. 
het tussen 1958 en $1979 .{ }^{61}$ Die stasie het plaaslike musiek aktief ondersteun as dit aan hulle vereistes voldoen het. Plaaslike vrystellings (wat eers deur die keurders goedgekeur is) het outomaties ten minste drie weke se lugtyd op Springbok Radio gekry. ${ }^{62}$ Springbok Radio het ook Afrikaanse musiekprogramme uitgesaai, sowel as Afrikaanse radiodramas, wat hoogs populêr was. Sommige radio programme het meer openlik ideologiese inhoud bevorder, meestal die nuus en aktualiteitsprogramme, terwyl die res oënskynlik neutraal gebly het deur om te sien na konserwatiewe "wit kleinburgerlike belange" - wat op sig self'n subtiele onderskrywing van die dominante ideologie. ${ }^{63}$

As 1950 'n nuwe era in kommersiële radio ingelui het, is dit oorskadu deur die veranderende politiese landskap. Dit is onmoontlik om populêre kultuur in Suid-Afrika vanaf 1950 te bespreek sonder om die ingrypende sosio-politieke veranderinge wat deur die NP ingestel is te oorweeg. Die verskerping van apartheid gedurende die 1950's en die konsolidasie van Afrikaner politiese mag onder die ideologie van Afrikanernasionalisme het goed-gedefinieerde grense afgebaken vir die konstruksie van hegemoniese Afrikaner-identiteit. Bowendien, deur die begin van die Wet op Onderdrukking van Kommunisme van 1950, het 'n uitgebreide netwerk van sekuriteitswetgewing 'n era van sensuur en self-sensuur ingelui. Die besluit oor wie nou eintlik 'n kommunis was - benewens dié wat hulleself openlik as sulks verklaar het - is aan die regering oorgelaat. ${ }^{64}$ Nog 'n wet uit die vroeë apartheidsjare, die Groepsgebiedewet van 1950, het die fondament gelê vir gedwonge verwydering van nie-blankes (om die Wet se rasseklassefikasie te gebruik) uit middestede en die wetlike skeiding van blanke en nie-blanke woongebiede. Kragtens hierdie Wet, en verskeie daaropvolgende wysigings, is inwoners verwyder uit sekere buurte naby aan die middestad, soos Sophiatown in Johannesburg - 'n lewendige kosmopolitiese gemeenskap wat besonder belangrik was vir die ontwikkeling van swart stedelike kulturele identiteite, wat musiekstyle soos marabi, kwêla and mbaqanga ingesluit het. 'n Paar jaar later in 1966, is Distrik Ses in Kaapstad as 'n wit buurt verklaar, wat gelei het tot die gedwonge verwydering van 'nie-blankes' in 1968. Terselfdertyd is die kultuurindustrie aansienlik beperk deur die apartheid regime en sy geaffilieerde ideologiese bondgenote insluitende die FAK, die NGK en die SAUK. Benewens 'n "kultuur van sensuur","5 het dit ook help vorm aan 'n Afrikaanse musiekbedryf wat op verskeie maniere die ideologie van Afrikanernasionalisme en rasse-eksklusiwiteit geëggo het.

Soos voorheen genoem is baie van die kommersiële Afrikaanse musiekvrystellings van die apartheidsjare sterk veroordeel vir hulle onoorspronklikheid, oppervlakkige en nie-politiese lirieke. Argumente dat sulke liedjies in ooreenstemming was met die dominante narratief van

61 Tertius Louw, e-pos kommunikasie, September 2013. Sover dit vasgestel kan word is geen amptelike trefferslyste gepubliseer nie. Inligting oor hierdie lyste is neergeskryf deur radio-luisteraars en het voorts in die hande van versamelaars soos Tertius Louw beland, aan wie die outeur geweldig baie dank verskuldig is.

62 Boet Pretorius, onderhoud met Outeur, 22 Julie 2013.

63 Hayman \& Tomaselli, "Ideology and Technology in the Growth of South African Broadcasting, 1924-1971", pp. 103-104, vertaal uit die oorspronklike.

64 C. Merritt, A Culture of Censorship: Secrecy and Intellectual Repression in South Africa (Kaapstad: David Phillip Publishers, 1994), p. 21.

65 Ibid., pp. 80-81. 
apartheid-ideologie is oortuigend. ${ }^{66}$ David Kramer het selfs na hierdie pop-liedjies verwys as "omo-Afrikaans, witter was wit," ${ }^{67}$ alhoewel dit nie voldoende is om die kompleksiteit van die Afrikaanse musiekbedryf van daardie tyd te beskryf nie. Wit Afrikaanse pop was nie die enigste musiekgenre wat nie die vereistes van apartheid se kulturele entrepreneurs weerstaan het nie:

Musically, few artists managed to open up any creative space within the rigid, anodyne, formula-bound styles fostered by the SABC's black radio stations. Those who remembered the previous era coined a derogatory term for the bouncy new popular music, mass-produced by the stations with the help of able, but guileless musicians from the countryside: they called it msakazo (broadcast). ${ }^{68}$

Dit is belangrik om te noem dat apartheid swart musiek onder die beskerming van 'n Suid-Afrikaanse musiekbedryf geplaas het wat gedomineer is deur witmense (in term van uitsaaiwese en toegang tot produksiewyses) wat hulle eie politieke agendas gehad het. Geset teen so 'n sosio-politieke agtergrond het gemengde-ras dinamika meer kompleks geraak. Christopher Ballantine se onderhoud met Edward Sililo, wat saam met Cele en Silgee se Jazz Maniacs gespeel het, is veral onthullend en toon aan hoe swart musikante komplekse rasse-politiek en diskriminerende wetgewing moes navigeer deur Afrikaanse liedjies aan te leer:

Well, you had to prove you were a musician, and if you were a plumber you had to prove you were a plumbing man. They took me to another place and I was told to play a piano. And, well, it's Afrikaner people: you play "Sarie Marais" and they are very happy ... 'Kom spiel "Sarie Marais", jong!' [hums] 'nee man, jy ken! Kom!' ... You just had to go do that, and when you come back, 'ja hy's 'n musikant, man!' An then they give it. [laughs]. ... And many of us could get these passes, and we used to help the other guys and tell them, 'Oh no, you just tell them you're this, and you play what they [want] you to play.'Because they'll ask you to play. 'Jy moet spiel! "Die hand vol vere", jong!' Now if you don't know "Die hand vol vere" - 'Jy's nie 'n musikant nie!' You must play an Afrikaner song. There you are, sign! Got my credentials: from there I was a musician. ${ }^{69}$

"Die hand vol vere" was 'n treffer van Hendrik Susan se groep en gesing deur die populêre Jurie Ferreira. ${ }^{70}$ Sommige wit Afrikaanse musikante was egter minder gepla deur raspolitiek. As 'n jong man het die ontslape Ollie Viljoen, trekklavierspeler en bekende boeremusiek-kunstenaar, kwêla geleer by ander swart musikante in Johannesburg in die 1950's, en het selfs met die penniefluitjie-meester Spokes Mashiyane opgetree. ${ }^{71}$ Dorothy Masuka, legendariese verbande jazz-sanger en mede-komponis van treffers soos "Hamba nontsokolo" en "Pata Pata", het met

66 B. Jury, "Boys to Men, Afrikaans Alternative Popular Music 1986- 1990", African Languages and Cultures, 9:2 (1996), p. 99; D. Martin, Sounding the Cape: Music, Identity and Politics in South Africa (Somerset-Wes, African Minds, 2013), p. 145; I. Byerly, "Mirror, Mediator, and Prophet: The Music Indaba of Late-Apartheid South Africa”, Ethnomusicology, 42:1 (1998), p. 14.

67 J. Roup, Boerejood (Auckland Park: Jacana Media, 2004), p. 161. Omo is 'n seeppoeier-handelsmerk wat op dié stadium aanspraak daarop gemaak het, in 'n reklameveldtog, dat dit wasgoed "witter as wit" maak.

68 C. Ballantine, Marabi Nights, p. 11.

69 Onderhoud met Edward Sililo in Ballantine, Marabi Nights, pp. 68-69.

70 D. C. Pretorius, Musieksterre Van Gister En Vandag: lewensketse en foto's van meer as 100 musieksterre, (Pretoria: Van der Walt, 1998), p. 224.

71 Onderhoud met outeur, Franschhoek, 22 Maart 2014. 
deernis teruggekyk na die gewildheid van tiekiedraai - 'n Afrikaans musiek-genre - onder die swart musikante in 1950's Johannesburg. ${ }^{72}$ Maar ingevolge die beperkinge van apartheid het baie van die beste swart kunstenaars (insluitend Masuka) in ballingskap gegaan.

\section{Nico Carstens}

Die suksesvolste van alle Afrikaanse musiekkunstenaars van die 1950's en 60's (wie se gewildheid nog sterk was in die daaropvolgende dekades), was die trekklavierspeler Nico Carstens. ${ }^{73}$ Hy het by Hendrik Susan se orkes aangesluit in 1945, op die ouderdom van 19 jaar. Die volgende jaar het hy sy eerste album opgeneem saam met Susan, en teen 1951 het hy sy eie plate gemaak. Hy het 'n besonder suksesvolle liedjieskryf vennootskap gehad met Anton de Waal (wat voorheen saam met Danie Bosman gewerk het, maar met beperkte sukses). Saam het hulle meer as 600 liedjies gekomponeer, wat nogal baie is in vergelyking met die 1937 uitgawe van die Volksangbundel, wat slegs 314 bevat het. Altesame het Carstens byna 2000 liedjies gekomponeer. Hy was die eerste Suid-Afrikaanse kunstenaar wat meer as 'n miljoen LP's verkoop het, 'n mylpaal wat hy in 1959 bereik het, 'n merkwaardige prestasie as mens in ag neem dat die eerste LP's eers in 1955 vrygestel is. ${ }^{74}$ Plaaslik was hy dus ewe gewild soos internasionale sterre soos Elvis en die country-sanger Jim Reeves. Op 'n kommersiële vlak was Carstens baie suksesvol, en dit is duidelik dat hy en De Waal op musiekresepte gefokus het wat aanklank gevind het by Afrikaanse gehore van die 1950's en 1960's. Hierdie tydraamwerk is natuurlik belangrik vir 'n aantal redes, onder andere die feit dat dit amper perfek oorvleuel het met die eerste twee dekades van apartheid. Ekonomies gesproke was hierdie generasie van Afrikaners veel meer welgesteld as die vorige een, en Carstens se openbare beeld, met windmakerige pakke en luukse Cadillacs, het dit weerspieël. Sy opgang het dus oorvleuel met 'n era van Afrikanernasionalistiese optimisme wat slegs 'n paar dekades later sou taan. Vele van sy albumomslae het gespog met nasionalistiese ikonografie soos ossewaens en dies meer, wat geïnterpreteer is as 'n subtiele manier om die belangrikste politieke narratief van die tyd te onderstreep. Froneman interpreteer dit egter as niks meer as pragmatiese bemarking gedurende 'n ekonomiese bloeitydperk nie. As die gesig van Afrikaanse musiek toe apartheid op 'n hoogtepunt was, was Carstens 'n bra vreemde figuur gereken teen die streng Calvinistiese norme van die beskaafde Afrikaner-samelewing. Hy het homself later bekeer na die esoteriese oosterse spiritualiteit van Sant Mat, wat ongewoon was onder godsdienstig konserwatiewe Afrikaners. Persoonlik het hy nie gevoel hy is in die kulturele stal van die NP gekoöpteer nie en verwys na 'n ongemaklike verhouding met die SAUK:

No, I don't feel that. I was, in any event, locked out of the SABC for I 5 years, through envy. All the heads of the music department, with the exception of Don Lamprecht in the late 1950s and early 1960s, could not take my success. I didn't get any transcription work. ... There's never been a Nico Carstens radio programme either, although with my success that would've happened anywhere else in the world. There was a TV documentary done three years ago by the then NNTV, but it's never been flighted for some reason. ${ }^{75}$

72 Persoonlike korrespondensie met outeur, Maart 2013.

73 Weereens, vir 'n meer gedetailleerde analise van Carstens se lewe en werk, sien Froneman se "Pleasure beyond the call of duty", pp. 136-146.

74 Pretorius, Musieksterre Van Gister En Vandag, p. 40.

G. O'Hara, “From Zambezi to Somma Ghoema”, Mail \& Guardian, 20 Desember 1996. 
Carstens het beslis groot internasionale sukses behaal - stellig meer as enige ander Afrikaanse musikant tot op hede. 'n Aantal internasionale kunstenaars het al weergawes gedoen van sy grootste treffer, "Zambezi", en Eddie Calvert s'n het no. 13 op die Britse treffersparade bereik. Hy het ook musiek geskryf vir Jim Reeves, wat Suid-Afrika in die vroeë 1960's besoek het. Sy eie musiek is internasionaal vrygestel, selfs so ver as in die VSA en Nieu-Seeland, en gedurende sy loopbaan het hy musiek vrygestel in omtrent elke beskikbare formaat, van 78's en LP's tot enkelsnitte, DVD's en CD's - waarskynlik die enigste Suid-Afrikaanse kunstenaar om dit te doen. Soos voorheen genoem het hy dikwels die lof besing van die bruin musikante van die Kaap:

I like the beat, I grew up in the Cape with music. There's a form of music in the Western Cape called Hotnot's Riel, which is not meant to sound derogatory. I have played with a lot of Malay and coloured people. There's also goema there. These kind of rhythms are exciting. ${ }^{76}$

En ook:

I spent a lot of my youth on farms, and on every farm you'll find labourers who take out their guitars after work or on weekends. They taught me the basic chords and the strumming of that particular Cape Coloured beat, which I could never find in the Transvaal. The only people who could do it were people like Stan Murray who also grew up in Cape Town. That's why Stan and I fitted in so well in those old recordings like 'Outa in die langpad'. Eddie Wyngaard, also from the Cape, is another. ${ }^{77}$

Carstens het ook gespeel met Stan Murray se Penny Serenaders, wat 'n aantal liedjies vrygestel het op Columbia se Carnival-reeks, wat spesifiek gemik was op bruinmense. Op “Tamatie vir die Partie", word die katalogusnommer gevolg met die letter "C" (vir die Engelse "coloured") - om aan te dui dat dit gemik was op 'n bruin musiekmark. Platemaatskappye het dikwels hulle markte ingedeel volgens taal en ras - Troubadour, het byvoorbeeld die letter "A" gebruik om dit as 'n Afrikaanse plaat te eien, vir die Afrikaanse marksegment geoormerk. Ander, effens vroeër, vrystellings deur die Penny Serenaders sluit in "Volstruisrivier" en "Sussie se Samba" in 1958, maar die "C" ontbreek hier.

\section{Kwêla}

In 1956 komponeer Strike Vilakazi "Meadowlands", 'n politieke liedjie wat geïnspireer is deur die gedwonge verwydering van inwoners van Sophiatown na wat eindelik Soweto wou word. "Meadowlands" is gesing in Engels en Tsotsitaal - 'n stedelike omgangstaal met 'n sterk Afrikaanse invloed wat deur swart werkers in Johannesburg gepraat is. ${ }^{78}$ Die eerste kwêla-musiek LP's wat spesifiek gemik was op 'n wit Suid-Afrikaanse gehoor is die jaar daarna vrygestel..$^{79}$ Kwêla beteken 'staan op', of 'klim op' en verwys na die polisievoertuie (wat ook soms

\footnotetext{
76 Ibid.

77 Pretorius, Musieksterre Van Gister en Vandag, p. 50.

78 Coplan, In Township Tonight!, p. 165.

79 Hierdie vrystellings was in langspeelformaat (LP) en was wat wit gehore verkies het.
} 

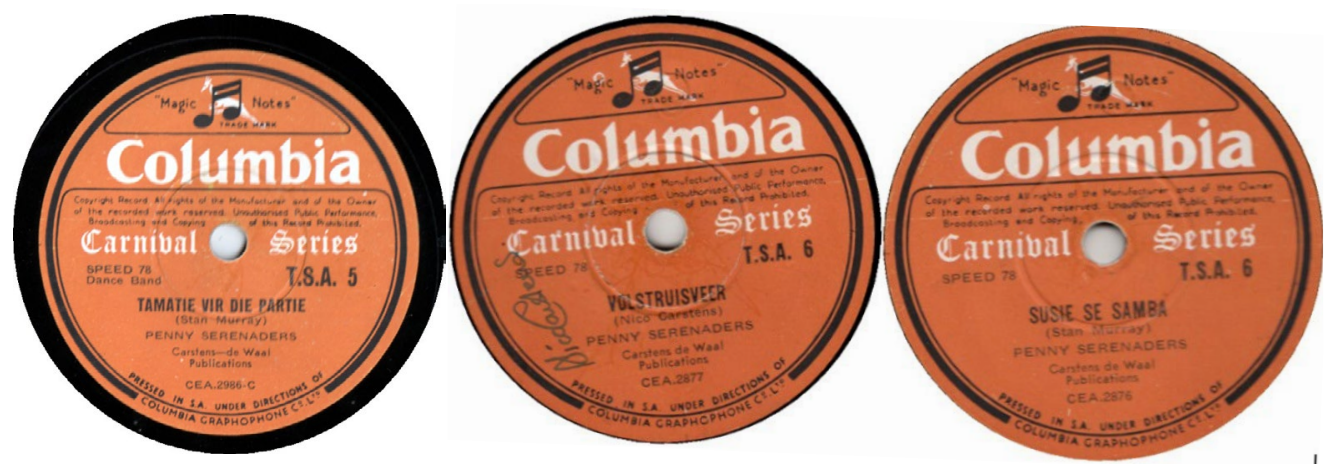

Musiek deur Nico Carstens en Stan Murray op Columbia se R wat spesifiek gemik is op die bruin mark, (C.E.A. 2986-C). Ook deur die Penny Serenaders (C.E.A. 2877 \& C.E.A. 2876).

kwêla-kwêla genoem is) wat pasoortreders en onwettige dobbelaars op straathoeke opgetel het. ${ }^{80}$ Dit is vernaamlik op 'n penniefluitjie gespeel, 'n goedkoop instrument, wat dit gewild gemaak het onder arm musikante orals oor die land. Kwêla se ontstaansgeskiedenis gaan terug na areas soos Sophiatown, en was deel van 'n uitvloeisel van musiek wat ontwikkel het uit 'n mengsel van plaaslike style, veral marabi, en jazz ingebring uit die VSA.

Kwêla het baie gewild geraak onder Afrikaners en 'n aantal wit Afrikaanse musiekkunstenaars het kwêla-albums verygestel, sommige met penniefluitjies, ander daarsonder. Lara Allen stel voor dat kulturele produksie en verbruik op hierdie tydstip in Suid-Afrika nog veranderlik was, ten spyte daarvan dat dit oorvleuel het met die vaslegging van apartheid. ${ }^{81}$ Kwêla se vermoë om die einste rasgrense oor te steek wat besig was om in die wetboeke opgevat te word wys dat “... die 1950's 'n kortstondige fase was waartydens dit duidelik was dat identiteite gekies kon word, voor aparte, eksklusiewe raskategorieë hegemonies geraak het." ${ }^{\prime 2}$ Die vrystelling van kwêla-musiek deur wit Afrikaanse musikante, wat gerig is op 'n "nie-blanke" gehoor, getuig beslis daarvan. Allen gebruik as voorbeeld die LP Something new from Africa ${ }^{83}$ om kwêla se trefkrag oor die rasgrense heen te illustreer. Die LP het gespog met 'n versameling van ses verskillende, uitsluitlik swart kwêla groepe. Hierdie kommersiële vrystelling van kwêla-musiek spesifiek vir 'n wit gehoor dui nie net op die doelbewuste kommodifiëring van swart stedelike populêre kultuur vir verbruik deur 'n wit mark nie, maar ook op die vestiging van wit begunstiging daarvan op die presiese oomblik wat apartheidbeleid ronduit daarop gefokus was om rasse-segregasie te verskerp. Die implikasie dat rasse-identiteite op hierdie stadium nog veranderlik was en nie hegemonies nie is baie belangrik, maar dit laat mens afvra of dit inderdaad wel so hegemonies geword het as wat algemeen aanvaar is in die jare daarna. In die Afrikaanse musiekbedryf was daar 'n aantal musiekvrystellings wat geblyk het om aan te dui dat kulturele hegemonie nooit volledig bereik is nie.

80 Martin, Sounding the Cape, p. 139.

81 L. Allen, "Kwela's White Audiences: The Politics of Pleasure and Identification in the Early Apartheid Period", in G. Olwage (red.), Composing Apartheid: Music For and Against Apartheid (Johannesburg: Wits University Press, 2008), p. 80.

82 Ibid.

83 Internasionaal vrygestel deur Decca (LK 4292) en plaaslik vrygestel deur Gallotone (GALP1015). 
Terwyl penniefluitjie-tipe kwêla al hoe meer gewild begin raak het in en om Johannesburg, was wit Afrikaanse musikante van die Kaap besig om musiek vry te stel wat hulle as kwêla bestempel het, maar wat deur bruin musikante geïspireer is. In 1957 het die pianis Albie Louw In Tune with South Africa, Vol. 5: KWELA vrygestel. Die nota op die plaatomslag sê kwêla is van Kaapse herkoms, spesifiek die Klopse Karnival vieringe op Nuwejaarsdag.

The inborn sense of rhythm, which is a heritage of the peoples of our land, has given us the irresistible lilt of the KWELA. No other pianist in South Africa is probably more qualified to interpret
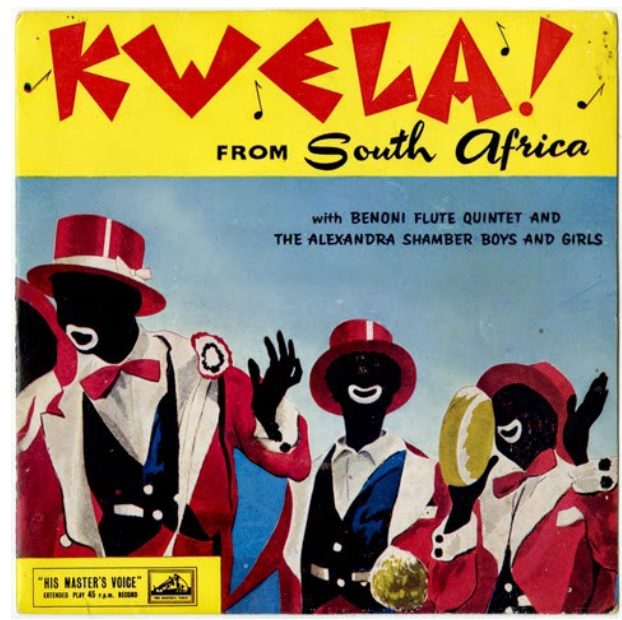

Verwysend na kwêla van die Kaap (JDLP I0008 HMV). the fascinating charm of KWELA than

Albie Louw. Albie was born in the Cape, and all his life he has been in contact with music of this type, listening to it, and absorbing it with appreciative interest. Albie's playing gives us the very essence and spirit of KWELA, which was spontaneously created by the Coons during Carnival time. ${ }^{84}$

Daarna het baie wit Afrikaanse musikante kwêla-liedjies vrygestel. Benewens die Penny Serenaders het Nico Carstens ook 'n aantal kwêla-albums vir 'n wit mark vrygestel. Kwêla het ook al hoe meer gewild geraak buite die grense van Suid-Afrika. In 1958 het Elias en sy Zigzag Jive Flutes die nommer 2 posisie op die VK treffersparade gehaal met hulle kwêla-liedjie “Tom Hark" ${ }^{85}$ Hoewel dit 'n instrumentale liedjie is, bevat die inleiding straatgesprekke in Tsotsitaal, met 'n onmiskenbare Afrikaanse geur.

Sommige wit Afrikaanse musikante het ook kwêla-musiek vrygestel wat meer geneig het na die Johannesburgse penniefluitjie-styl. Fred Wooldridge het met sy 1961 vrystelling "Penniefluitjie-kwêla" ${ }^{86}$ die nommer 10 posisie op die LM Radio trefferparade gehaal in April $1962 .{ }^{87}$ Dit het die temalied geword vir die uiters populêre oggend radio program Flink uit die vere, aangebied deur Fanus Rautenbach en uitgesaai op die SAUK se Afrikaanse diens. Flink uit die vere is vir die eerste keer op 16 Oktober 1961 op die lug uitgesaai, en vir die volgende 13 jaar was "Penniefluitjie-kwêla" die oggendwekker vir duisende Afrikaanse radio-luisteraars. ${ }^{88}$ Op verskeie maniere som dit die kompleksiteite op van die Afrikanerkultuurindustrie gedurende apartheid.

84 Teks op plaatomslag van In Tune with South Africa, Vol. 5: KWELA

85 http://www.rock.co.za/files/vinyl_sa_index2.html [besoek 12 Augustus 2013].

86 Pêrel, p. 203, April 1961.

87 Tertius Louw, e-pos kommunikasie met outeur, September 2013.

88 E. Terblanche, "Fanus Rautenbach, 1928- 2011", beskikbaar by http://www.argief.litnet.co.za/ [besoek 14 April 2013]. 


\section{Die Briels}

Terwyl baie wit kunstenaars kwêla-musiek vrygestel het, is die ander kant van die spektrum verteenwoordig deur die sentimentele liedjies van Die Briels. Frans en Sannie Briel het hulle loopbaan as opnamekunstenaars in Augustus $1954^{89}$ met die album My gryse ou moeder afgeskop en het uiteindelik 'n somtotaal van 482 liedjies opgeneem..$^{90}$ Hulle liedjies was doelbewus sentimenteel en is deur die FAK beskou as 'n verleentheid. 'n SAUK memorandum van 6 Augustus 1957 dui aan dat radiostasies verbied is om twee van hulle liedjies, "Saans deur die tralies" en "'n Engel in die hemel", uit te saai. ${ }^{91}$

Die Briels was werkersklas Afrikaners - Frans Briel het vir die spoorweë gewerk en later vir Yskor, terwyl Sannie later 'n vurkhyser-bestuurder geword het, ${ }^{92}$ en hulle musiek het dikwels verwys na die realiteite van 'n werkersklas-bestaan. Naas ander kunstenaars soos Danie Pretorius, en Koos en Hester Nortje - met die platemaatskappy Troubadour - het hulle doelbewus gesoek vir koerantstories oor rampe wat hulle liedjies kon inspireer. Sulke swartgallige sentimente was gewild, en die albums het goed verkoop onder ouer luisteraars, terwyl die jonger demografie geneig het om nie na Afrikaanse musiek te luister nie. ${ }^{93}$ Ten spyte van die verkoopssyfers het Die Briels arm gebly, want kunstenaars het nie tantième verdien nie en is slegs 'n vaste fooi vir die opname betaal. ${ }^{94}$

In 1961 reik hulle "Die myner's lied" uit, geïnspireer deur die Coalbrook-mynramp van Januarie 1960, wat die lewens van 435 mynwerkers eis, 429 van hulle swart trekarbeiders van Lesotho en Mosambiek. ${ }^{95}$ Liedjies soos "Ter nagedagtenis aan 435 mynwerkers" en "Die myner's lied" was somber aandenkings aan die tragedie maar was desnieteenstaande baie gewilde liedjies in 'n tyd toe ander Afrikaanse musiek doelbewus opgeruimd was. 'n Ander tragedie, die Sharpeville-slagting, vind 'n paar maande na die Coalbrook-mynramp plaas. Dis miskien nie verbasend dat hierdie gbeurtenis nie in enige Afrikaanse liedjies voorkom nie. Sentimentaliteit daar gelaat, Die Briels was deel van 'n uitgelese groep Afrikaanse musikante van die 1950's en 1960's wat enigsins verwys het na die ontberinge van 'n lewe in Suid-Afrika en op dié manier in teenstelling was met die optimisme van die opgewekte Euro-kitsch hoofstroom. Dit was moontlik as gevolg hiervan dat hulle vir 'n kort rukkie weer gewild was saam met die groep alternatiewe Afrikaanse kunstenaars van die laat 1980's. ${ }^{96}$

89 Sannie Briel het hierdie datum verskaf vir hulle eerste album-opname (sy gee die presiese datum aan as 24 Augustus 1954), maar ander bronne gee dit as 1956, met die uitreiking van Sentimentele wysies, I. Roggeband, 50 Stemme: Die grootste name in Afrikaanse musiek (Kaapstad: Delta, 2009), p. 39.

90 J. Kruger, “Die Wegsterf van 'n Lied”, Rapport, 3 Junie 1990, p. 6.

91 SAUK Memorandum, 6 Augustus 1957, met vergunning van Stephanus Muller.

92 Roggeband, 50 Stemme, p. 39.

93 Boet Pretorius telefoniese onderhoud, 22 Julie 2013.

94 Ibid.

95 B.Pogrund,http://www.timeslive.co.za/opinion/2010/10/14/the-435-sa-miners-who-didnt-make-it [besoek 03 Junie 2013].

96 T. Engelbrecht, “Kranse dreun, maar Ouma Briel kom weer”, Die Burger, 2 June 1990; B. Hough, “Vir die 'Orgel' sê mens nie 'Sit dit af' nie!', Rapport, 17 June 1990, p. 5. 
Die Troubadour-platemaatskappy was ook verantwoordelik vir die vrystelling van hoogs polities-gelaaide enkelsnitte deur swart sangers soos Dorothy Masuka, wie se liedjie "Dr. Malan" die reël bevat "Dr. Malan het moeilike wette". ${ }^{97}$ Dit is deur die owerhede verban en het die aandag getrek van die sekuriteitspolisie, wat aanleiding gegee het tot Masuka se bannelingskap. Sulke sensuur en hardhandige metodes was 'n aanduiding van die groeiende mag van die apartheid-regering en sy onderdrukking van andersdenkendes. In die dekades daarna sou dit al hoe erger raak soos die regime gereageer het op'n verskeidenheid veiligheidsrisiko's - denkbeeldig en werklik - wat ook die plaaslike musiekbedryf beïnvloed het.

97 http://freemuse.org/archives/957 [besoek 20 Mei 2015]. 


\section{HOOFSTUK VIER}

\section{Die apartheid regime, rock 'n roll en die Afrikanerjeug ${ }^{1}$}

\section{Die Nasionale Party (NP) en Afrikanermag van die 1960's}

Gedurende die 1960's het die mag van die NP en sy geaffilieerde kulturele organisies'n hoogtepunt bereik. Suid-Afrika se republiekwording in 1961 en die land se uittrede uit die Statebond, asook die suksesvolle onderdrukking van swart politieke organisasies soos die African National Congress (ANC) en die Pan Africanist Congress (PAC), het Afrikanernasionalistiese oorheersing bevestig. Hierdie mag het nie net politieke beheer beteken nie, maar ook massiewe optimisme onder Afrikaners omdat hulle suksesvol was om die armoede en kulturele disintegrasie wat die vorige generasie nog bedreig het, te oorwin. Een belangrike faktor was die ekonomiese welvaart en opkoms van 'n groot Afrikaner middelklas toe apartheid sy hoogtepunt bereik het, wat veranderende lewensstyle en verbruikerspatrone ingelui het soos Afrikaners meer welvarend geraak het. ${ }^{2}$ Die invloed en mag wat die uiters selfversekerde, vasberade en intellektueel geslepe Verwoerd gedurende sy termyn as Eerste Minister, wat in 1958 begin het, afgedwing het, was kragtig. ${ }^{3}$ Hy het egter 'n uitgesproke kritikus gehad in die Afrikaanse digter N.P. van Wyk Louw,

1 Hierdie hoofstuk se hooftemas is al deur die outeur aangespreek in 'n vorige artikel: "Radio Apartheid': Investigating a History of Compliance and Resistance in Popular Afrikaans Music, 1956-1979", South African Historical Journal, 66:2, (2014), pp. 349-370.

2 A. Grundlingh, "Are We Afrikaners Getting too Rich? Cornucopia and Change in Afrikanerdom in the 1960s", Journal of Historical Sociology, 21:2/3 (2008), pp. 143-165; W. Beinart, Twentieth Century South Africa, (Oxford: Oxford University Press, 2000), pp. 181-184.

3 H. Giliomee, Die Afrikaners: 'n Biografie (Kaapstad: Tafelberg, 2003), pp. 519-520. 
wie se Nasionale Liberalisme, wat in dieselfde jaar gepubliseer is as wat Verwoerd aan bewind gekom het, het die beginsels vergestalt van oop gesprekke en politieke kritiek van binne die Afrikaner laager. Van Wyk Louw het aangevoer vir 'n morele stryd om die oorleweing van die Afrikanerdom, en het 'n paar Afrikaanse joernaliste geïnspireer om Verword se beleid in hul publikasies te bevraagteken. ${ }^{4}$ Die prominentste was Piet Cillié (redakteur van Die Burger) en Schalk Pienaar (die sub-redakteur wat vir homself naam gemaak het deur sy dekking van die 1938 Eeufeestrek). Pienaar was krities teenoor Verword vir sy siening oor Afrikaner kulturele waardes en dat hy “ ... asof dit die natuurlikste ding op aarde is homself as arbiter aangestel het om in elke geval te besluit wat goed en wat sleg vir die Afrikaner is." Verwoerd was beslis invloedryk genoeg om die kulturele sfeer ook te beïnvloed. Van Wyk Louw was openlik krities teenoor die idee van "organisasie manne" (stoere nasionaliste) "se pogings om die Afrikaanse kulturele lewe te probeer kanaliseer in die stroom waarin die politieke en kulturele leiers dit wou dwing." Hierdie "organisasie manne" was groot voorstaanders van apartheid-ideologie en het hulleself verbind daaraan om te verseker dat die kulturele lewe van die Afrikaner voldoen aan die (teen hierdie tyd reeds gevestigde) idees van aparte ontwikkeling en die Afrikaner se dominante rol binne hierdie raamwerk. Van Wyk Louw se kritiek, sowel as dié van Cillié en Pienaar, was subtiel en geplaas binne die Afrikanerdom, en het steeds 'n geloof in die legitimiteit van apartheid as 'n geheel laat blyk.

\section{Die SAUK}

Een van die apartheidregering se grootste bates in sy pogings om mag uit te oefen oor die bevolking, was die nasionale uitsaaier. Die SAUK (Suid-Afrikaanse Uitsaaikorporasie) was nie net 'n belangrike instrument vir die uitsaai van kultuur nie (soos wat die geval is met ander openbare uitsaaiers soos die BBC), maar ook die vorming daarvan. ${ }^{7}$ Die organisasie het relatief onafhanklik van die staat gefunksioneer vandat dit in 1936 gestig is tot en met 1959, toe die ultra-nasionalistiese Piet Meyer, die voorsitter van die FAK se Radiokomitee in die 1940's, aangestel is as voorsitter deur Albert Hertzog, Minister van Pos en Telegraafwese in Verwoerd se kabinet. ${ }^{8}$ Gevolglik het die nasionale uitsaaier veel meer begin voldoen aan ontoegeeflike apartheid ideologie, gewapen met'n mandaat om uitsaai-inhoud te beskerm teen ondermynende materiaal, veral gedurende die polities-onstabiele vroeë 1960's.

Dit het nie net kunstenaars en platemaatskappye beïnvloed in hoe hulle vrystellings benader het nie, maar dit het ook nuusverslaggewing aan die Suid-Afrikaanse publiek affekteer. Die mag van die SAUK het ná grootskaalse tegnologiese vooruitgang in die 1960's - soos die oorskakeling na FM - dit vir die korporasie moontlik gemaak om sy omvang uit te brei en nuusverslaggewing te beïnvloed, of dit selfs te onderdruk. Die beperkte dekking van internasionale protes ná die Sharpeville-slagting in 1960 is 'n goeie voorbeeld hiervan. Ander belangrike internasionale gebeure is geïnterpreteer sodat dit die regering se beleid weerspieël het, soos die sluipmoord op

4 A. Mouton, "Reform from within': Schalk Pienaar, the Afrikaans press and apartheid", Historia, 45:1 (2000), p. 153.

5 Aangehaal in H. Giliomee, Die Afrikaners: 'n Biografie, p. 489.

$6 \quad$ Ibid., p. 505.

7 R. Tomaselli, K. Tomaselli en J. Muller (reds.), Currents of Power: State Broadcasting in South Africa (Kaapstad: Anthropos, 1989), p. 10.

8 P. Meyer, Nog nie ver genoeg nie: 'n Persoonlike rekenskap van vyftig jaar georganiseerde Afrikanerskap (Johannesburg: Perskor, 1984), p. 103. 
Martin Luther King Jr., wat gebrandmerk is as 'n "neger burgerregte opstoker". 9 Ingrid Byerly merk op dat daar hoër vlakke van staatsingryping op Suid-Afrikaanse musikante was in tye van politieke opstand, soos wat te sien was gedurende 1960 met die Sharpeville-slagting en die verbanning van die ANC en die PAC. ${ }^{10}$ In 1966 is Radio RSA, die SAUK se internasionale diens, gevestig. Dit het in 'n aantal tale uitgesaai, insluitend Engels, Afrikaans, Swahili, Frans, Portugees, Nederlands en Duits. Die diens het hoofsaaklik opiniestukke en nuus uitgesaai wat die apartheid-regering se ideologieë weerspieël het. Sensuur het strenger geraak ná die Wet op Publikasies van 1974, met die stigting van die invloedryke Direktoraat van Publikasies. ${ }^{11}$ Ook van uiterse belang was die verbod op televisie tot 1976, wat in Hoofstuk Vyf bespreek word. Dit het wit Suid-Afrika, veral die Afrikaners, tot a mate van die wêreld geïsoleer. Gedurende 'n dekade van belangrike liberale, sosiale en kulturele bewegings wêreldwyd, het die Suid-Afrikaanse samelewing in die teenoorgestelde rigting beweeg. Afrikaner organisasies was vasberade om hulle volk en jeug te beskerm teen 'n gevaarlike buitewêreld, en deurgaans is die lekkerliedjie uitgesaai om 'n subtiele boodskap te stuur dat alles onder beheer was. Platemaatskappye soos Brigadiers het 'n deurslaggewende rol gespeel om nuwe Afrikaanse kunstenaars te vestig as kommersiële suksesverhale deur te kyk na Europa (maar nie die Europa wat deur die 1968 studente-opstande gedefinieer is nie) vir inspirasie en het dikwels Schlager-melodieë geneem en Afrikaanse lirieke daarvoor geskryf. Die beste voorbeeld hiervan is moontlik die musiek van Gé Korsten, wat opera in Wene en München studeer het. ${ }^{12}$ Korsten en Min Shaw se klankbaan vir die 1968 rolprent Hoor my lied, waarin beide ook verskyn het, was 'n enorme treffer. Die album het 200000 eenhede in ses maande verkoop. ${ }^{13}$

Dit was nie net polities-ondermynende liedjies wat gedurende hierdie tyd verban is nie. Die liedjies van hoofstroom Afrikaanse kunstenaars soos Die Briels, ${ }^{14}$ asook Gé Korsten se 1966 huldeblyk aan Rhodesiese onafhanklikheid, "Songs of Courage”, is gesensor. Dit was 'n besondere vreemde besluit, aangesien 'n mens 'n mate van solidariteit met 'n ander Afrika-land wat ook deur 'n wit minderheid regeer word, sou verwag. ${ }^{15}$ Liedjies met die woord "god" in die titel, selfs al was dit gospel-liedjies, is gesensor. Dit is wat gebeur het met Charles Jacobie se "It's no secret (what God can do)" ("Dis geen geheim (wat God kan doen nie)"). ${ }^{16}$ Groep Twee, een van die gewildste Afrikaanse groepe, se gospel-liedjie, "U is ons Ster", ${ }^{17}$ is verban in 1972, wat aantoon dat sensuur nie beperk was tot polities-ondermynende kunstenaars nie. Dit, en die bykomende bewyse, ondermyn die idee dat die regime spesifiek nie-konfronterende popmusiek bevoordeel het. Op hierdie manier het kommersiële Afrikaanse musiek voldoen aan die kulturele vereistes van Afrikanernasionalisme en apartheid, selfs al was die kunstenaars self nie polities gemotiveerd nie.

9 J. Daniel en P. Vale, “South Africa: Where were we looking in 1968?", p. 140, in P. Gassert en M. Klimke (reds.), 1968 - Memories and Legacies of a Global Revolt (Washington, DC: German Historical Institute, 2009).

10 I. Byerly, "Mirror, Mediator, and Prophet: The Music Indaba of Late-Apartheid South Africa", Ethnomusicology 42: 1 (1998), p. 44.

11 Wet op Publikasies no. 42, 9 Oktober 1974.

12 I. Roggeband, 50 Stemme: Die grootste name in Afrikaanse musiek (Kaapstad: Delta, 2009), p. 97.

13 Ibid., p. 98.

14 "Saans deur die Tralies", en "'n Engel in die Hemel”, SAUK Memorandum, 6 Augustus 1957, met dank aan Stephanus Muller, sien Hoofstuk Vier.

15 PD. 9086.

16 CBS Exp 2126.

17 BR 3062. 
Hoewel sensuur radio-uitsendings van die SAUK beïnvloed het, kon die Suid-Afrikaanse publiek steeds radio-uitsendings buite die landsgrense opvang. Die prominentste was LM Radio in Mosambiek, wat instrumenteel daarin was om Suid-Afrikaanse gehore bloot te stel aan musiek wat óf verban was óf bloot nie deur die SAUK gespeel is nie. ${ }^{18}$ Toe die SAUK die meerderheidsaandele in LM Radio gekoop het in 1972, was dit die einde van 'n era van onafhanklike uitsaaiwese in Suider-Afrika. ${ }^{19}$ Desnieteenstaande was sensuur nooit omvattend nie. Selfs al het die SAUK sekere liedjies verban, het dit nie noodwendig beteken dat die albums nie in Suid-Afrika beskikbaar was nie. Kunstenaars soos Bob Dylan, byvoorbeeld, wie

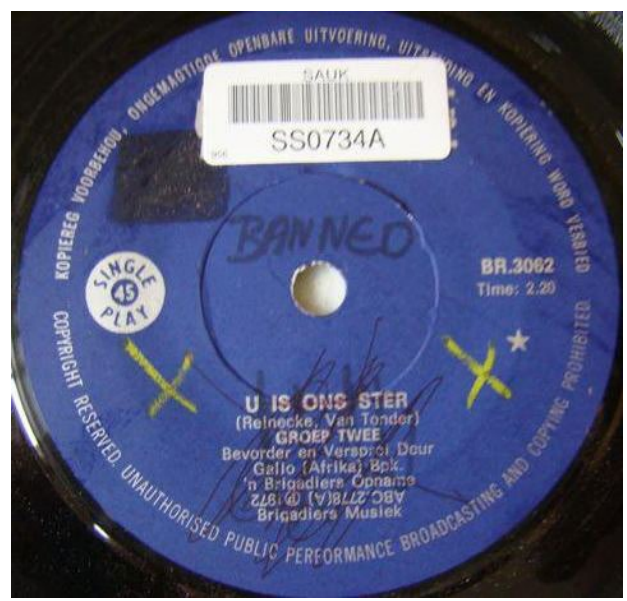

Groep Twee se " $U$ is ons Ster" is in 1972 verban (Brigadiers Musiek, BR 3062). ${ }^{23}$ se 1963-treffer "Blowin in the Wind" verban was, het steeds goed verkoop met 'n groot aanhang onder die Suid-Afrikaanse jeug. ${ }^{20}$

Op 'n vergadering in Januarie 1963 het Douglas Fuchs, Direkteur van Programme en later Direkteur-Generaal van die SAUK, aangekondig dat rock- en boeremusiek as spesialis musiek-genres geklassifiseer word met 'n marginale gehoor en behoort daarom vermy te word ten gunste van ligte, angename en melodiese musiek. Musiek wat te "esoteries, te 'rocky', te 'rolly' of te hard" behoort vermy te word tensy daar spesifieke snitte was wat nuuswaardig was. ${ }^{21}$ Die SAUK is ook onder druk geplaas deur 'n konserwatiewe samelewing - veral Engelse en Afrikaanse witmense - wat maklik ontstig is. 'n Paar jaar later is Fuchs geforseer om enige verdere uitsendings van Andrew Lloyd Webber se musiekblyspel Jesus Christ Superstar te verbied. Dit ná 'n eenmalige aand-uitsending in Maart 1971 wat onmiddelik deur 'n vloedgolf van klagtes gevolg is deur "kulturele organisasies, kerke en individuele luisteraars".22 Dat dit in die eerste plek uitgesaai is wys dat die SAUK moontlik nie so konserwatief was as die kulturele organisasies en die kerk nie.Die volgende aanhaling uit 'n ander SAUK vergadering wys dat die organisasie nogtans volledig gekoöpteer is in die politiese en ideologiese sienings van die regering:

We want to try to give the English-speaking conservative student a weekly late-night programme, like "Studentevaria", on the Afrikaans transmission, a kind of student's forum with the type of music students like with "hidden persuation (sic)" in between. This must be broadcast under the Chairmanship of a live and vital - from Rhodes, Natal, Wits, Cape Town, etc., and sandwiched in between the music the message of the conservative against Nusas should be put. ${ }^{24}$

18 http://lmradio.org/History.html [besoek 30 April 2013].

19 Ibid.

20 Personality, November 11, 1965.

21 Douglas Fuchs, SAUK programdirekteur, vergadering van senior SAUK programsamestellers, 16 Januarie 1963 (INCH), Douglas Fuchs Versameling, PV 851, vertaal uit die oorspronklike.

22 INCH, Douglas Fuchs Versameling, PV 851.

23 Met dank aan Tertius Louw.

24 Fuchs, Spesiale SAUK vergadering, 30 April 1964, INCH, Douglas Fuchs Versameling, PV 851. 
NUSAS was die liberale Nasionale Unie van Suid-AfrikaanseStudente wat teen die 1970's een van die vernaamste wit anti-apartheid liggame was. Opname- en uitsaai-ateljees by die SAUK is verdeel volgens ras, ${ }^{25}$ dus mag musikante van verskillende rasse nie saam opgeneem het nie. Platemaatskappye in privaatbesit kon nie bekostig om aparte ateljees te bou nie wat gelei het daartoe dat kommersiële opnames soms gemaak is deur veelrassige ateljee-musikante en boonop, dat dieselfde ateljees swart en wit musiek respektiewelik opgeneem het. ${ }^{26}$ Ten spyte van die beperkings opgelê deur die SAUK was die organisasie natuurlik nie in so 'n magtige posisie dat dit alle musiek wat ingedruis het teen die dominante apartheid-narratief kon uitroei nie. Chris Smit se albumomslag verteenwoordig hierdie kompleksiteit. ${ }^{27}$

Dit is vrygestel in die eerste kwartaal van $1962^{30}$ en is ' $n$ gelaaide metafoor wat onder meer die "vreemde samelewing" simboliseer waarna Charles Hamm verwys het. ${ }^{31}$ Die omslag bevat'n aantal interessante - en ongewone - elemente. Die kunstenaar se tatoeëermerk maak 'n duidelike stelling teen die konserwatiewe norm van die tyd en is waarskynlik bedoel om uit te lok, met die doelbewuste ooglopende plasing daarvan. Chris Smit is ongetwyfeld wit, maar hy bespeel 'n instrument wat met swart musikante geassosieer word, en sy haarstyl herinner aan die "Ducktails" - 'n marginale groep mense wat deur die meerderheid wit Suid-Afrikaners as ongewens beskou word. ${ }^{32}$ Die dubbelsinnighede strek tot by die titel

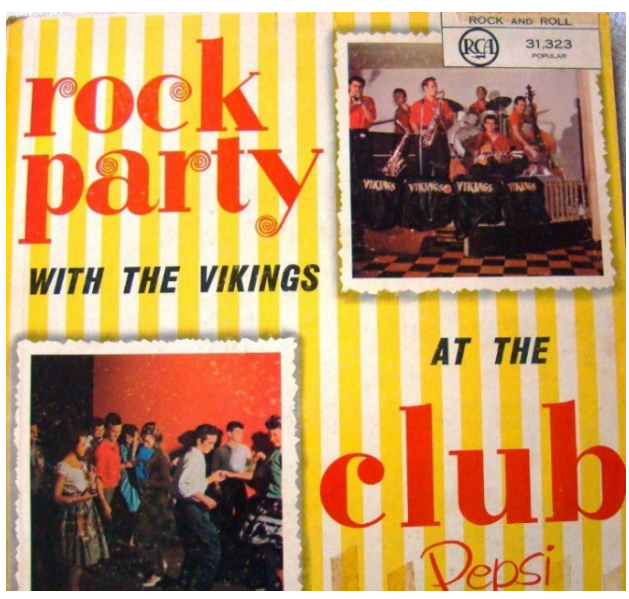

Rock Party with the Vikings at the Club Pepsi (RCA 31 ,323), 1959 - die eerste Suid-Afrikaanse rock-album? ${ }^{29-}$ van die album en die snitte wat op die omslag gelys word. Die titel word in beide Afrikaans

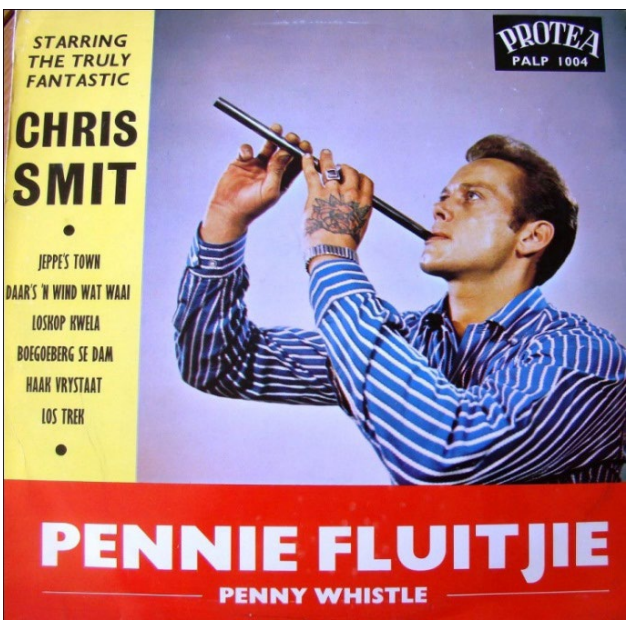

Chris Smit se Penniefluitjie, 1962 (Protea, PALP I884). ${ }^{28}$

25 Ollie Viljoen, onderhoud met outeur, Gordonsbaai, 18 September 2013.

26 Rob Allingham, elektroniese kommunikasie, 26 September 2013.

27 Protea, PALP1004, 1962, met dank aan https:// www. facebook. com/ pages/ Marq-Vass-Southern-African-Music-Collectibles [besoek 15 April 2013].

28 Met dank aan Tertius Louw.

29 Ibid.

30 Marq Vas, e-pos kommunikasie met outeur, 16 April 2013.

31 C. Hamm, "Rock 'n Roll in a Very Strange Society", Popular Music, 5:1 (1985), pp. 159-174, vertaal uit die oorspronklike.

32 K. Mooney, "Ducktails, flick-knives and pugnacity: subcultural and hegemonic masculinities in South Africa, 1948-1960", Journal of Southern African Studies, 24:4 (1998), pp. 753-774. 
(Penniefluitjie) en Engels (Penny Whistle) gegee, wat aandui dat dit gemik is op 'n gemengde gehoor; en die meeste van die snitte is verwerkte Afrikaanse gunsteling, soos "Boegoeberg se dam" en "Haak Vrystaat", terwyl "Loskop kwêla" 'n doelbewuste verwysing is na kwêla.

Chris Smit was ook 'n lid van een van Suid-Afrika se eerste rock-groepe, The Vikings, wie se eerste album, Rock Party at the Pepsi Club with the Vikings, in 1959 uitgereik is. ${ }^{34}$ Die omslagaantekening noem dat Smit sy eie groep gelei het teen die ouderdom van 16 (hy was 20 in 1959) en dat hy gekonsentreer het op saksofoon en penniefluitjie in "Boere Musiek [sic] Kaap-Maleis en Kwêla". Dit is interessant dat Allen verwys na die ooreenkomste tussen $k w e ̂ l a$ en rock 'n roll, veral as dit as dansmusiek geluister word. Op hierdie manier het dit gefunksioneer as 'n soort "plaaslike rock'n roll". ${ }^{35}$ Maar Smit se album was nie 'n kommersiële sukses nie. Protea was nie een van die groot platemaatskappye nie en sou waarskynlik soos van die kleiner, onafhanklike maatskappye soos bv. Meteor, eerder musiek vrygestel het wat nie deel was van die hoofstroom nie met die hoop dat dit 'n jonger, nismark sou lok. ${ }^{36}$ Ten spyte van die gebrek aan kommersiële sukses, lê die ware belang van hierdie albumomslag in sy posisie binne 'n spesifieke tyd en plek, en die feit dat dit enigsins bestaan. Die mengsel van veelrassige

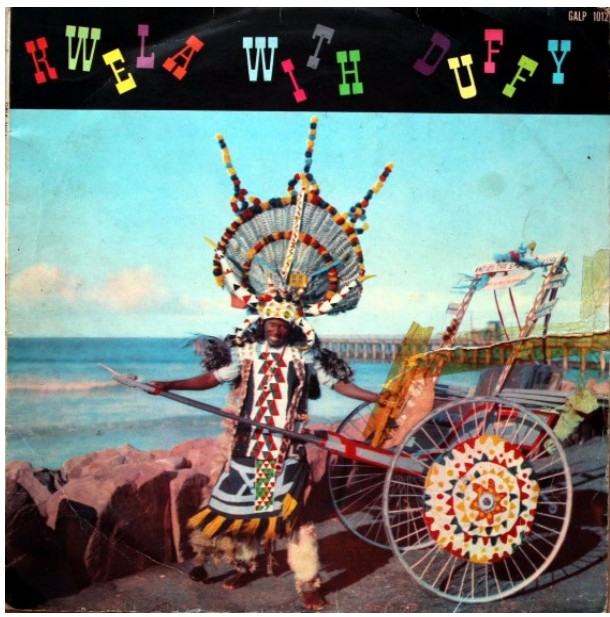

"Kwêla" with Duffy (Gallo GALP I0।2).

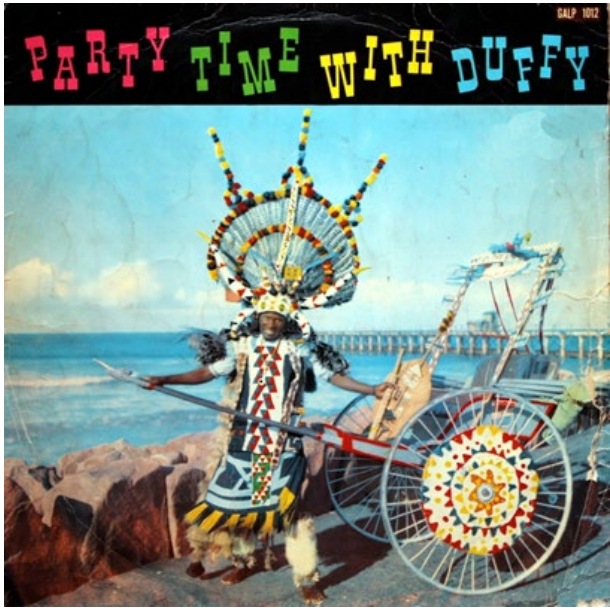

"Party" with Duffy (Gallo GALP I0 I 2) ${ }^{33}$ musikale invloede, die uitlokkende beeld van die kunstenaar, die tweetalige albumtitel en die Engelse byskrif, en veral die tydsberekening (1962) is alles belangrik en dra by tot die skerpheid. Apartheid was op sy kruin, en die NP was in ferm beheer terwyl sy kulturele bondgenote die NG Kerk, die FAK en die SAUK almal besig was om saam te sweer om Afrikanernasionalistiese identiteit te handhaaf en om dit te beskerm teen ondermynende elemente, of hulle nou denkbeeldig of eg was. En tog het die dubbelsinnighede van betekenis, wat in musiek weggesteek is, daarin geslaag om op te duik selfs in hierdie beperkte omgewing. Nog 'n uitskieter-vrystelling van die laat 1950's was Duffy Ravenscroft se Kwêla with Duffy, wat die platemaatskappy verander het na Party with Duffy.

33 Met dank aan Tertius Louw.

34 https://www.facebook.com/pages/Marq-Vass-Southern-African-Music-Collectibles [besoek 15 April 2013].

35 L. Allen, "Kwêla's White Audiences: The Politics of Pleasure and Identification in the Early Apartheid Period", in G. Olwage (red.), Composing Apartheid: Music For and Against Apartheid (Johannesburg: Wits University Press, 2008), p. 83.

36 Boet Pretorius, telefoniese onderhoud met die outeur, 22 Julie 2013. 
Hierdie titelverandering dui aan dat die kwêlaverwysing die album se Engelse gehoor kon vervreem het, of dat die platemaatskappy ten minste so gedink het. Hoewel sy prominentste lede erg gekant was teen uitheemse invloede op Afrikanerkultuur is dit interessant om op te merk dat daar geen direkte bewyse is wat aandui dat die FAK bekommerd was oor nóg country, nóg $k w e ̂ l a-m u s i e k$ se gewildheid onder witmense of die invloed daarvan op Afrikaanse musikante nie. Die SAUK, aan die ander kant, het nie geskroom om 'n Afrikaanse liedjie, "Kom kwêla vanaand met my" (kunstenaar onbekend) en die album waarop dit ingesluit is, in Desember 1957 van die lug te verban nie. ${ }^{3738}$ Daar was duidelik nie 'n totale verbod op kwêla-liedjies nie, siende dat

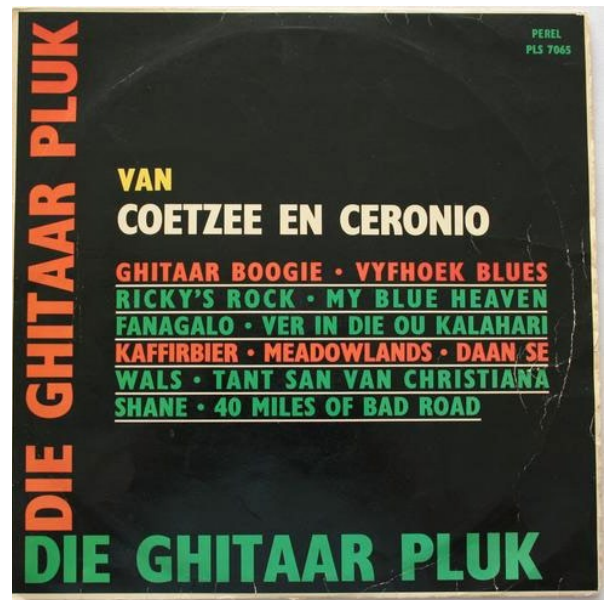

Coetzee en Ceronio se Die Ghitaar Pluk, c. 1965 (Perel PLS 7065). ${ }^{37}$ Fred Wooldridge se "Penniefluitjie-kwêla" elke dag vir 13 jaar oor die lug gespeel is. Teen die agtergrond van sulke komplekse rassepolitiek mag die identifikasie van wit Afrikaners met die musiek van die "ander" idiosinkraties voorkom, maar dit kan ook gelees word as opportunisties en pragmaties, want kwêla was goeie besigheid. 'n Ander album wat idiosinkraties voorkom is Coetzee en Ceronio se Die Ghitaar Pluk.

Die presiese vrystellingsdatum is onbekend (dit is iewers tussen 1964 en 1966), en dit is 'n versameling van instrumentale kitaarverwerkings. Verskillende weergawes van "Meadowlands" is verban, ${ }^{39}$ maar die deuntjie was gewild genoeg om op die album ingesluit te word, moontlik te danke aan The Meteors, wat in 1963 die nommer 13 posisie op LM Radio se trefferparade gehaal het daarmee ( $\mathrm{al}$ is dit ook verban deur die SAUK). ${ }^{40}$ Die liedjies "Ghitaar Boogie" en "Vyfhoek Blues" het snittitels in gemengde tale, wat opspraakwekkend was vir daardie tyd, en die verwysings na "boogie", "blues" en "rock" maak dit duidelik dat die album gemik is op 'n jonger demografie. "Fanagalo" is ook opgeneem deur Nico Carstens en verwys na die pidgin-Zulu streekstaal wat deur swart trekarbeiders op die myne gepraat is.

\section{Rock en country}

Om die kompleksiteit van identiteitspolitiek van hierdie vroeë era van apartheid verder te verhoog is 1956 ook die jaar wat Elvis Presley - en dus rock-musiek oor die algemeen - voorgestel is aan Suid-Afrikaanse gehore. Elvis het besonder gewild geraak onder Engelse en Afrikaanse wit jongmense, en het amper twee miljoen albums in net drie jaar verkoop. ${ }^{41}$ Interessant genoeg het populêre musiek Engelse uitsendings van die SAUK gedomineer van 1957-1959. Daar is omtrent geen klassieke musiek gedurende hierdie tyd uitgesaai nie, wat 'n sterk teenstelling is met die jare daarvoor en sedertdien. ${ }^{42}$

37 Met dank aan Tertius Louw.

38 SAUK interne memorandum aan "C" samestellers, 4 Desember 1957, te danke aan Stephanus Muller.

39 Strike Vilakazi se oorspronklike weergawe, asook 'n weergawe deur Nico Carstens opgeneem in 1968.

40 Tertius Louw, e-pos kommunikasie met die outeur, September 2013.

41 Hamm, "Rock 'n Roll in a strange society", p. 159.

42 R.J. van den Berg, "Die Musiekaktiwiteite van die SAUK", (MA Dissertasie: Universiteit van Potchefstroom, 1976), Diagram 2, p. 203. 
Rock-musiek is ook in die politieke arena gebruik. Besoeke van rock-sangers vanuit die buiteland het aan die een kant konsternasie onder konserwatiewe Afrikaners veroorsaak, maar ook nuuskierigheid aan die ander kant. Die Afrikaanse koerante het met behoedsame fassinasie berig oor die besoek van Tommy Steele, 'n Britse sanger. ${ }^{43}$ Die NP het die gevare van rock-musiek as 'n politieke wapen gebruik teen die oorwegend Engelssprekende Verenigde Party in die 1958 nasionale verkiesing en die party blameer vir die feit dat die Afrikanerjeug hulle rug gedraai het op Afrikanerkultuur. ${ }^{44}$ Hierdie skuif om te kapitaliseer op rock-musiek in die politieke arena was veel meer pragmaties as die referate geskryf deur verskeie uitvoerende raadslede van die FAK wat in die organisasie se tydskrif, Handhaaf, gepubliseer is of by Volkskongresse aangebied is, soos die een in Stellenbosch in 1957. By hierdie geleentheid het die FAK raadslid, Benedictus Kok, 'n referaat gelewer oor die invloed van radio, die grammofoon, komponiste van ligte musiek en uitgewers van Afrikaanse musiek, en na popmusiek as "musiekpornografie" verwys. ${ }^{45}$ Die NP se pragmatiese benadering het vir 'n paar jaar voortgegaan en het rock-musiek sy groeiende gehoor toegelaat, terwyl die Afrikaanse pers en die NGK (en kulturele organisasies soos die FAK) terselfdertyd hul skerp veroordeling daarvan versag het. ${ }^{46}$ Pragmatisme het egter grense gehad. Gedurende Steele se toer is 25 seuns en meisies in Springs gearresteer omdat hulle 'n "rock-'n roll sessie" op die ondergrondse verdieping van 'n gebou gehou het, hoewel geen klagtes gelê is nie. ${ }^{47}$ 'n Paar dae na die voorval is die Britse rock-sanger Terry Dene as 'n "ongewenste persoon" verklaar deur die Departement van Binnelandse Sake en verbied om in Suid-Afrika te toer. ${ }^{48}$ Verder is Suid-Afrikaners slegs blootgestel aan die mees gematigde rock-kunstenaars uit die buiteland, wat rock'n wyer gehoor as net die jeug verseker het:

\begin{abstract}
In the next decade, dozens of British and American singers were persuaded to make the long journey to the tip of the African continent, among them Dickie Valentine, Cliff Richard, Connie Francis, Pat Boone, Billy Fury, Dusty Springfield, Adam Faith, Vera Lynn and Alma Cogan. This roster both reflected and helped to shape the musical taste of white South African youth: middle of the road rock; often more pop than rock; several stages removed from the rhythm and blues and country and western roots of the first wave of American rock 'n roll of the 1950s; more often British than American. South African "rock" musicians fell into these same patterns. Adults became more and more tolerant of this music as it became evident that no real harm was being done, and that much music labelled "rock 'n roll" was not too different from the music they had enjoyed during their youth. ${ }^{49}$
\end{abstract}

Baie van hierdie kunstenaars is onder druk geplaas omdat hulle apartheid Suid-Afrika besoek het. 'n Bekende akteursunie van die VK was Equity, wat daarin geslaag het om Billy Fury te oortuig om sy reis te kanselleer. Equity het aangedring daarop dat sy kunstenaars optree voor onbeperkte gehore, wat byna onmoontlik was onder apartheidwetgewing. Ná 'n speurder drie bruin tieners by 'n Adam Faith konsert in Wynberg verwyder het, het Faith in Januarie 1965 al

43 Die Burger, p. 15, 25 Maart 1958.

44 Hamm, "Rock'n Roll in a strange society", p. 162.

45 P. McClachlan, Matieland, 1, 3 Desember 1957, p. 21.

46 Hamm, "Rock 'n Roll in a strange society", p. 163; Die Burger, 7 Januarie 1965.

47 Die Burger, 24 Maart 1958.

48 Die Burger, 27 Maart 1958.

49 Hamm, "Rock 'n Roll in a strange society", p. 162. 
sy oorblywende konserte kanselleer weens die druk waaronder Equity hom geplaas het. ${ }^{50}$ Die konsertpromotor het hom gedagvaar vir kontrakbreuk, en Faith is op die vliegtuig gearresteer met sy vertrek uit Johannesburg. ${ }^{51}$

Rock-musikante was nie die enigste buitelandse kunstenaars wat Suid-Afrika op hierdie stadium besoek het nie. Moontlik die gewildste kunstenaar wat die land besoek het was die Amerikaanse sanger, Jim Reeves, (vergesel deur pianis Floyd Cramer en kitaarspeler Chet Atkins). Hy het Suid-Afrika besoek in 1962 ná verstommende albumverkope in die land. Amerikaanse kultuur het die Suid-Afrikaanse verbeelding aangegryp met Westerns wat so gewild was in die bioskoop en country-musiek wat tot 'n wye en veelrassige gehoor gespreek het. ${ }^{52}$ Aanhangers het op Reeves toegesak by die Jan Smuts lughawe in Johannesburg en ook voor sy hotel. ${ }^{53}$ Hy het vervolgens twee Afrikaanse albums opgeneem en in 'n plaaslike rolprent gespeel: Kimberley Jim, 'n musiekblyspel met musiek wat geskryf is

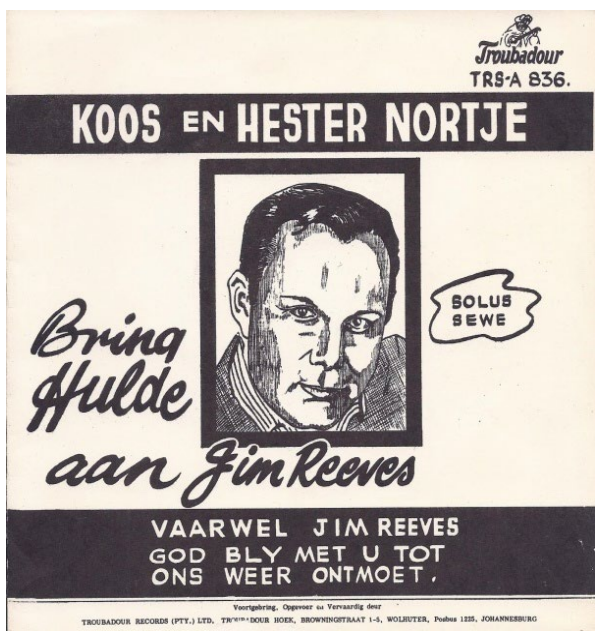

Sentimentele Afrikaanse musiek:

Koos \& Hester Nortje se Vaarwel Jim Reeves (Farewell Jim Reeves) (Troubadour TRS-A 836). deur plaaslike musikante soos Nico Carstens, Anton de Waal en Gilbert Gibson. ${ }^{54}$ Sy lof is selfs besing in 'n liedjie deur sentimentale sangers, soos Koos \& Hester Nortje ná sy dood in 'n vliegongeluk in $1964 .{ }^{55}$ Country-musiek het gewild gebly onder Afrikaners.

Dit is moeilik om te skat hoe gewild Reeves was onder die jonger demografie. Elvis Presley het agt treffers op LM Radio gehad (wat 'n groot jeugmark bedien het). In Desember 1961 (net voor Reeves se besoek), het die hèle top vyf bestaan uit sy treffers, ${ }^{56}$ wat die gewildheid van rock-musiek in Suid-Afrika beaam het. Hierdie gewildheid was deel van die wêreldwye impak van massa-vervaardigde Amerikaanse en Europese populêre kultuur. ${ }^{57}$

\section{Afrikanerjeug}

Die Afrikanerjeug het nie Afrikaanse musiek as egte popmusiek geag nie, veral nie ná die koms van rock 'n roll nie. ${ }^{58}$ Dit was 'n belangrike ontwikkeling wat die veranderende demografieë

50 Die Burger, 7 Januarie 1965.

51 Die Burger, 9 Januarie 1965.

52 W. Beinart, Twentieth Century South Africa (Oxford: Oxford University Press, 2000), p. 183.

53 M. Titlestad, “The South African Life and Afterlife of Jim Reeves”, The Journal of South African and American Studies, 15:4 (2014), p. 499.

54 Ibid., pp. 500-503.

55 "Vaarwel Jim Reeves".

56 Tertius Louw, e-pos kommunikasie September 2013.

57 http://www.recording-history.org/HTML/impact_recorded_music12.php [besoek 23 Augustus 2012].

58 J.E. Pieterse (red.), Jeug en vrye tyd III (Johannesburg, Voortrekkerpers, 1967), pp. 102-103, in A. Grundlingh, "'Are We Afrikaners Getting too Rich?' Cornucopia and Change in Afrikanerdom in the 1960s", Journal of Historical Sociology, 21:2/3 (June/September 2008), p. 154. 
van Afrikaanse musiekgehore weerspieël het. Koos Kombuis sou later spot dat die idee om Britse en Amerikaanse-styl popmusiek in Afrikaans te maak gedurende die 1960's “so verregaande was soos Monty Python-styl humor in die Derde Reich", 59 maar sommige plaaslike groepe het hulleself tog wel gewaag aan Afrikaanse rock-liedjies. Moontlik die vroegste voorbeeld van Afrikaanse rock-musiek was 'n lewendige optrede deur Johnny Kongos and The G-Men in die 1963 rolprent Huis op Horings?, waarin hulle 'n liedjie met dieselfde naam gespeel het. Dit is egter nooit op plaat uitgereik nie. ${ }^{60}$ Die gewildste Afrikaanse rock-vrystellings van die 1960's het gekom van 'n plaaslike Engelse rock-groep, The Bats. Hulle Afrikaanse treffer "Groen en Goud", met sy rugbytema, was in 1968 op beide LM Radio en Springbok Radio 'n groot treffer. ${ }^{61}$ Dit was 'n baie vroeë vorm van Afrikaanse rock en bevat'n konsertinasolo wat rock en boeremusiek gemeng het. Die verwysings na gewilde Afrikaanse rugbyspelers en nasionale helde, soos Dawie de Villiers, Frik du Preez en Tiny Naudé, saam met die bekende konsertina klanke, het gebruik gemaak van sterk Afrikaner kulturele ikone, wat die liedjie se gewildheid onder Afrikaners verseker het. Kort ná die sukses van "Groen en Goud" het die Bats die eerste vollengte Afrikaanse rock-album uitgereik,

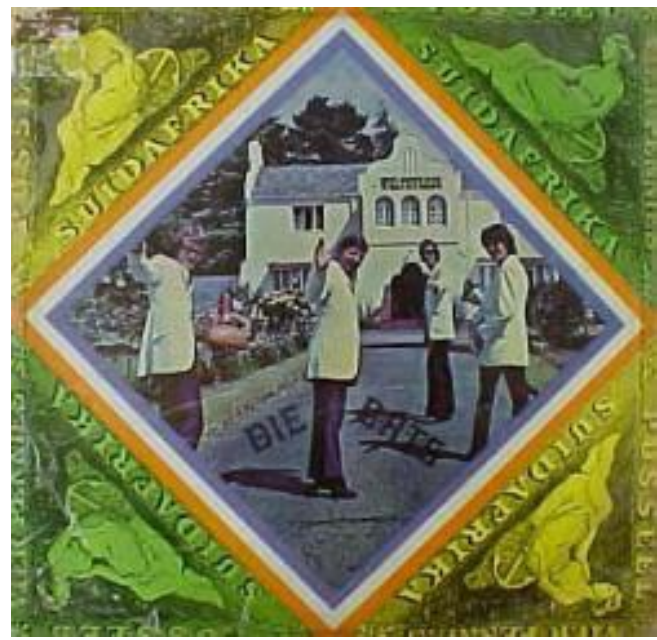

Die eerste vollengte Afrikaans rock album? Die Bats se Weltevrede in 1968 (CBS ALD 8139).

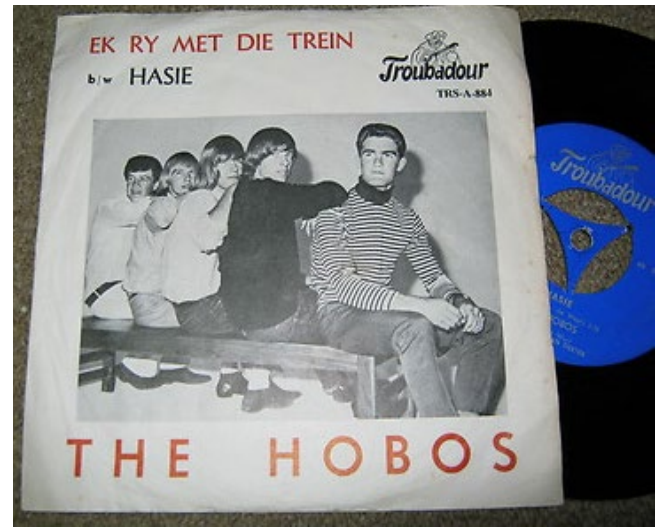

Een van die vroegste Afrikaanse rock-vrystellings:

The Hobos met "Hasie" (Troubadour TRS-A 884). genaamd Weltevrede. ${ }^{62}$ Een van hulle ander liedjies, "Weltevrede Stasie", was ook'n treffer op die Springbok-trefferparade. ${ }^{63}$

Daar was egter vroeër, minder bekende groepe wat Afrikaanse rock voor die Bats uitgereik het. Moontlik die eerste van hierdie groepe was The Bravados, wat in 1964 "Gogga” uitgereik het - 'n Beatles verwysing, met "Soek 'n Ander" op die B-kant. Hulle was eintlik 'n Engelssprekende groep, met 'n Skots-gebore hoofsanger, Frank Lakie (wat albei liedjies geskryf het), en 'n Afrikaanse huldebleik aan die Beatles was logies genoeg daardie tyd. In 1966 het The Hobos

59 K.A. Kombuis, Seks \& Drugs \& Boeremusiek: Die Memoires van 'n Volksverraaier (Kaapstad: Human \& Rousseau, 2000), p. 191.

60 Met dank aan Tertius Louw.

61 Ibid.

62 http://www.rock.co.za/files/vinyl_sa_index2.htm [besoek 16 Augustus 2013].

63 Louw, e-pos kommunikasie, September 2013. 
'n rock weergawe van Al Debbo se treffer "Hasie" (een van Carstens en De Waal se vroegste pogings om 'n liedjie saam te skryf) op die Troubadour-merk uitgereik.

Hierdie opnames was absoluut die uitsondering op die reël. Afrikaanse musiek het oor die algemeen nie tot die jongmense gespreek nie. Beslis nie die sentimentele liedjies van Die Briels, of die opera-pop van Gé Korsten en ander Afrikaanse sangers nie. Die ideoloë van die NGK en die FAK was hoogs bekommerd hieroor. Grundlingh verwys na meningspeilings wat in die middel-sestigs geneem is by die Universiteit van Pretoria, wat gewys het dat byna die helfte van alle Afrikaner jongmense (meer as die Engelse jeug) LM Radio verkies het en dat hulle rock en pop bo populêre Afrikaanse musiek verkies het. ${ }^{64}$ 'n Latere meningspeiling onder Afrikaanse studente by Stellenbosch bevestig dat die Afrikanerjeug "nie in Afrikaanse musiek geïnteresseerd" was nie, dat "alle [Afrikaanse popliedjies] te lig of van te lae gehalte was om pop genoem te word", en dat "Afrikaans nie geskik is vir popmusiek nie". ${ }^{65}$ Boonop het sommige studente baie sterk daaroor gevoel dat Afrikaanse popmusiek nie deur sangers soos Min Shaw, Gé Korsten, Gert "Pottie” Potgieter, of "Afrikaanse 'gemors' en kougom” gesing behoort te word nie. ${ }^{66}$

Ander peilings onderneem deur die FAK se Nasionale Jeugraad in 1968 toon dat die Afrikanerjeug steeds sterk onder die invloed van die NGK was. 'n Groot meerderheid was gereelde kerkgangers (omtrent 60\% het ten minste eenmaal per week kerk toe gegaan, terwyl 'n derde meer as eenmaal per week gegaan het). Slegs 'n weglaatbare persentasie het geen godsdienstige affiliasie gehad nie, terwyl meerderheid lidmate was van die NGK. Die Afrikanerjeug het meer konserwatief geleef as die wit Engelse jeug (wat ook aan die peilings deelgeneem het en minder betrokke was by godsdienstige aktiwiteite) en is meer direk beïnvloed deur kerkverwante aktiwiteite. 'n Groot persentasie van die Afrikanerjeug het ook gesag gerespekteer. ${ }^{67}$ As dit gelees word saam met die bogenoemde uitslae van die ander peilings het die gewildheid van rock-musiek onder Afrikaner jongmense nie beteken dat hulle enigsins minder konserwatief was nie.

'n Verskeidenheid van sosiale faktore het 'n rol gespeel daarin dat hulle begin neig het na nuwe genres uit die buiteland, wat vir die kulturele leiers kommerwekend was. Die koms van rock-musiek het saamgeval met die opkoms van'n wit middelklas jeugkultuur wat deel uitgemaak het van die nuwe verbruikerskultuur, wat gekoppel was aan die groeiende ekonomie. ${ }^{68}$ Wit middelklas voorstede het blikkiesdorpe en verafgeleë plase op die platteland, die woonplekke van die vorige generasie vervang, want Afrikaners het begin ryk word. Dit beteken dat die klas-gebaseerde spanning tussen die klein Afrikaner elite en die groot werkersklas veel minder was teen die laat 1950's as in die eerste helfte van die twintigste eeu. Dit was grootliks as gevolg van die feit dat Afrikaners wat begin voordeel trek het uit apartheid. Op 'n politiek vlak het die NP sy mag en invloed gekonsolideer soos Suid-Afrika toenemend 'n totalitêre staat geword het met 'n regering wat intolerant was teen kritiek. Die FAK en die SAUK was ideologies gekant teen volksvreemde Anglo-Saksiese invloede en het gepoog om hierdie vreemde invloede teë te

64 Ibid., 154.

65 FAK Musiekkommissie vergaderingnotule, jaar onbekend, maar waarskynlik 1974. US Biblioteekargiewe, G.G. Cilliers Versameling, MS 210, 89a.

66 Ibid.

67 A.G.S. Gous, “Ons jeug vrees die toekoms”, Die Huisgenoot, 20 September 1968, pp. 14-15.

68 Grundlingh, “Are We Afrikaners Getting too Rich?”, p. 153. 
werk deur ligte Afrikaanse-musiekkompetisies te borg en opdrag te gee vir die vervaardiging van jeug-radio programme. ${ }^{69}$ In 'n artikel uit Desember 1974 het G.G. Cillié, op die stadium die onder-voorsitter van die FAK, die volgende geskryf oor popmusiek en die Afrikanerjeug:

I. Die woorde van sommige popliedjies het 'n twyfelagtige strekking, en enkeles is selfs ondermynend.

2. Vir baie van ons Afrikaner-tieners is popmusiek hulle hele musiek-belewenis. Dit verdring alle ander musiek by hulle en dus ook ernstige musiek en hulle eie volksmusiek.

3. Ons tieners se popliedjies kom feitlik almal van Engeland en Amerika en druk dus 'n Angel-Saksiese stempel op ons jong mense af op 'n baie gevoelige stadium van hulle ontwikkeling. In die FAK glo ons dat dit gevare inhou vir die kulturele vorming en vastigheid van die betrokke jong mense.

4. Deurdat hulle slegs popliedjies sing, sing ons tieners feitlik net in Engels en word hul moedertaal in hierdie opsig afgeskeep. ${ }^{70}$

Die FAK het ook 'n boek van Afrikaanse lekkersingliedjies gepubliseer wat gemik was op die Afrikanerjeug, maar die sukses daarvan was beperk:

In 1976 verskyn bv ook die eerste bundel Lekkersingliedjies nadat die FAK besef het dat die hedendaagse Afrikaanssprekende jeug 'n groot behoefte aan ligte Afrikaanse liedjies het. Hierdie 30 liedjies, waarvan ses tradisionele volkswysies is, is almal deur Dirkie de Villiers in 'n moderne idioom ingeklee. Die resultaat was 'n boekie wat beantwoord het aan sy aanvanklike doelstelling: vermaak vir die breedste volkslaag, met gunstelinge soos: Groen koringlande, Die padda wou gaan opsit, Ai meisie-meisie, Liefste Madeleine en Groen is die land van Natal. ${ }^{71}$

Groep Twee, die gewilde tweemanskap van Sias Reinecke en Gert van Tonder, het in 1966 die enkelsnit "Die padda wou gaan opsit" vrygestel as die B-kant vir "Oukraalliedjie". ${ }^{22}$ Die enkelsnit het goue verkoopstatus bereik, en "Oukraalliedjie” was nommer drie op Springbok Radio se nasionale trefferparade. Ironies genoeg is "Die padda wou gaan opsit" 'n vertaling van 'n ou Engelse volksdeuntjie genaamd "Froggy went 'a-courtin", en daar is weergawes deur Amerikaanse protessangers Woody Guthrie, Pete Seeger en later Bob Dylan ook uitgegee. ${ }^{73}$ Selfs Elvis het 'n cover gedoen in 1970, sowel as Bruce Springsteen in $2006 .{ }^{74}$ Dit is egter twyfelagtig of die FAK geweet het van "Die padda" se protesliedstatus in die VSA.

Die SAUK was meer pragmaties en het in 1969 die plaaslike Engelse rock-groep, The Peanut Butter Conspiracy, genader om instrumentele verwerkings van Afrikaanse liedjies in 'n rock-idioom op te neem vir uitsending op Afrikaanse tiener radio programme. ${ }^{75}$ Die NGK

69 SAUK Jaarverslag, 1968, p. 24, te danke aan Monica van Deventer, SAUK Inligtingbiblioteek, 18 November 2011.

70 G.G. Cilliers, "Die musiekkomitee van die FAK en Popmusiek”, Handhaaf, Desember 1974, pp. 6-7.

71 A. le Roux, Handhaaf, April/Mei 1988, p. 6.

72 Persoonlike kommunikasie met Tertius Louw, 17 September 2014.

73 http://www.bobdylan.com/de/node/26858 [besoek 20 Mei 2015].

$74 \mathrm{http} / /$ www.springsteenlyrics.com/lyrics/f/froggiewentacourtin.php [besoek 20 Mei 2015].

75 Vir die Jong Klomp, SAUK, LT 12530. 
was ook ernstig bekommerd dat dit uit voeling sou raak met die jeug. 'n Tipiese waarskuwing teen die ondermynende invloed van rock-musiek kan gevind word in Die Kerkbode, die nuusbrief van die NGK. In sy artikel "Psigedeliese Musiek en die Jeug"76, maak Dr. H.G. van der Mer 'n paar baie twyfelagtige waarnemings oor psigedeliese (of rock-) musiek. Eerstens definieer hy "psigedelies" as "sielsvernietigend", hoewel die letterlike betekenis daarvan "sielsmanifesterend" is. ${ }^{77}$ Hy noem ook die Beatles sataniese kommuniste. Die res van sy artikel is 'n emosie-belaaide noodkreet om Afrikanerkinders te beskerm teen die bose, sataniese, kommunistiese hippies en

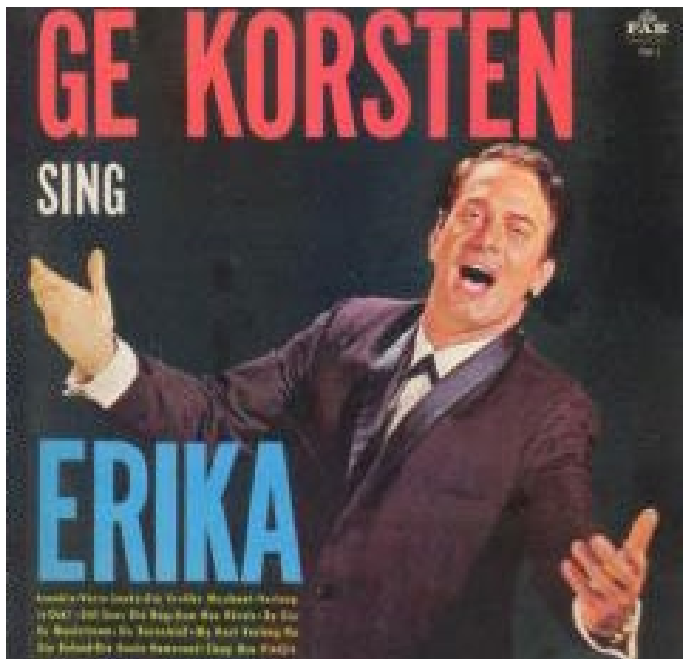

Gé Korsten Sing Erika, 1966 (Die FAK Plateklub/ Brigadiers, FAK 2). hulle rock-musiek. Sulke tipe kritiek was algemeen en was 'n emosionele pleidooi gemik op die meerderheid Afrikaners betrokke by die NGK (insluitend die jongmense). Die syfers wys egter dat ten spyte van hierdie emosionele druk (en moontlik as gevolg daarvan) het die Afrikanerjeug die musiek wat so swartgesemeer is, verwelkom.

Die SAUK was meer prakties as die NGK. Hoewel verskeie albums gekrap is om te verseker dat radio platejoggies hulle nie kon speel nie, is aanstootlike snitte net so maklik van speellyste weggelaat. Die drukpers het hierdie voorbeeld nagevolg, soos waargeneem kan word in 'n brief in Die Huisgenoot in 1966 waarin 'n groep koshuisskoliere van Kimberley kla oor die feit dat daar nie genoeg dekking is van popsterre soos Elvis Presley, die Beatles en die Rolling Stones nie. ${ }^{78}$ Afrikaanse popkunstenaars het niks sulke probleme gehad nie. Net drie weke voor dié brief verskyn het, vier Die Burger, in samewerking met die FAK en Brigadiers platemaatskappy, die vrystelling van Gé Korsten se nuwe album, Gé Korsten Sing Erika :

\begin{abstract}
"Afrikaans wil ook in musiek sy man kan staan! Waar daar vroeër 'n taalstryd te vegte was, is daar vandag opnuut 'n musiek-en sangstryd!" Skryf Albie Venter in 'n geesdriftige aantekening op die omslag van Gé Korsten SING ERIKA, 'n langspeelplaat onlangs deur die F.A.K. met die samewerking van Brigadiers Bpk., voltooi is. Hoewel 'n mens dit miskien self 'n bietjie anders sou formuleer, stem jy tog tot groot hoogte saam met wat mnr. Venter hier sê. Afrikaans is te dikwels in die verlede beskou as net geskik vir "balke toe"-musiek. ${ }^{79}$
\end{abstract}

76 H.G. van der Hoven, "Psigedeliese Musiek en die Jeug", Die Kerkbode, 26 Januarie 1972, pp. 102-104.

77 Van die Antieke Griekse psuchē (soul), en dēlōsē (manifest) http://www.thefreedictionary.com [besoek 30 April 2013].

78 Die Huisgenoot, 23 September 1966, p. 11.

79 “Afrikaners wil ook in musiek sy man kan staan!”, Die Burger, 1 September 1966. 
"Erika" is 'n masjeerliedjie wat kom van die Waffen-SS van die 1930's, gekomponeer deur Herms Niel, wat die nodige eer gegee word op Korsten se album. Die sanger Jurie Ferreira het ook 'n weergawe van "Erika" - met Afrikaanse lirieke - wat hy in die laat 1950's saam met Nico Carstens en sy orkes gedoen het. ${ }^{80}$ Die feit dat 'n Duitse masjeerlied van die Tweede Wêreldoorlog herverpak kon word as 'n suksesvolle kommersiële Afrikaanse vrystelling in 1966, terwyl die Beatles terselfdertyd verban was ná John Lennon se opspraakwekkende "Jesus-aanmerking" is noemenswaardig. Dit herbevestig ook die gaping tussen die smaak van jonger en ouer Afrikaanse luisteraars.

In 'n ongewone antwoord op Lennon se aanmerking het Dr. J.A. Heyns - 'n senior dosent in teologie aan die Universiteit Stellenbosch - 'n artikel vir Die Huisgenoot geskryf waarin hy bevraagteken het of John Lennon korrek was met sy stelling dat die Beatles meer gewild as Jesus was. ${ }^{81}$ Hy gebruik dit as 'n waarskuwing teen "Beatle-aanbidding" en die wegkwyning van die Christendom in moderne tye. Hy noem ook die mislukte pogings in Suid-Afrika om anti-Beatle ondersteuning onder die publiek te wen en die NGK wat versuim het om kommentaar te lewer oor die saak. Die SAUK het gereageer deur alle uitsendings van musiek van die Beatles te verban tussen 1966 en 1971, hoewel hulle albums steeds beskikbaar was in Suid-Afrika. Dit is duidelik uit hierdie artikel dat Lennon se aanmerking nie te veel opspraak onder die Suid-Afrikaanse publiek gewek het nie en dat die musiek van die Beatles desnieteenstaande aanhou verkoop het.

In 1970 het EMI deur hulle filiaal, MFP, die gewilde Springbok Hit Parade-albums van stapel gestuur. Dit het uiters goed verkoop onder jong Suid-Afrikaners en het dikwels Suid-Afrikaanse kunstenaars ingesluit. ${ }^{82}$ Hierdie albums was goedkoop en het oor die algemeen bestaan uit plaaslike weergawes van treffers uit die buiteland. Plaaslike treffers is ook opgeneem, waarvan die meerderheid in Engels was, maar 'n klein aantal Afrikaanse liedjies het die albums gehaal, soos Gé Korsten en Ian and Dix se "Sonder Jou" wat ingesluit is op die Springbok 30-album van 1976 (MFP 54763). ${ }^{83}$ Die albums was ook bekend vir hulle omslagfoto's van halfnaakte wit vroue, wat Drewett geïnterpreteer het as 'n verteenwoordiging van patriargale patriotisme:

For the sexing of album covers followed distinctly racial and ethnic line: white, never black, women accompanied reference to national symbols as the "springbok" in the belief that these symbols represented white aspirations. ${ }^{84}$

Sy uitbeelding van albumomslae as draers van nasionalistiese kodes is 'n belangrike waarneming en bly relevant wanneer dit toegepas word op Afrikaanse albumomslae (en ander visuele media) van die post-apartheidsera. ${ }^{85}$ Dis belangrik om in gedagte te hou dat Suid-Afrika nooit heeltemal geïsoleerd was van wêreldwye kulturele neigings nie: baie poptreffers uit die buiteland was treffers in Suid-Afrika, en is ingesluit om die Springbok Hit Parade-albums, saam met musiek van plaaslike groepe. Die uitlokkende albumomslae het ook die konserwatiewe norme

80 Columbia 11009 \& DSA 3003.

81 Die Huisgenoot, 16 September 1966.

82 http://springbokhits.blogspot.com/p/springbok-hit.html [besoek 24 Julie 2013].

83 Ibid.

84 M. Drewett, "Packaging Desires: Album covers and the representation of apartheid" in G. Olwage (red.), Composing Apartheid: Music for and Against Apartheid (Johannesburg: Wits University Press, 2008), p. 123.

85 Sien D. Pretorius, “The Visual Representations of Masculinities in Die Huisgenoot Tempo Magazine”, Communicatio, 39:2 (2013), pp. 210-232. 
uitgedaag en het dikwels gelei tot konflik met die Direktoraat van Publikasies. ${ }^{86}$ Om 'n wye draai was selfs hierdie uitloklikheid egter deel van die wit oppergesag konsep en het dit 'n dominante wit manlike weergawe van patriotisme verteenwoordig.

\section{Wêreldwye bewegings}

Die 1960's was 'n era van ingrypende verandering vir die wêreld ver buite Suid-Afrika se bewaakte grense. Die sosiale bewegings wat hulle hoogtepunte bereik het, hoofsaaklik in die VSA en Europa, het hulself bewys as baie nuttige gevallestudies oor die dinamiek tussen musiek en sosiale bewegings. Herbert Marcuse het die "estetiese dimensie" van hierdie liberale sosiale bewegings in die 1960's benadruk, en het voorgestel "dat dit hoofsaaklik in kuns en musiek was wat sosiale bewegings tradisies van weerstand en kritiek 'onthou' het" ${ }^{77}$ In Suid-Afrika het die owerhede hierdie bewegings met agterdog bejeën. Die hoof kulturele bedreigings vir die Volk was kommunisme, liberalisme en humanisme. Die FAK se tydskrif, Handhaaf, wat in 1963 die lig gesien het, het dikwels artikels gepubliseer deur vername Afrikaner kulturele leiers wat gewaarsku het teen die ondermynende effekte wat hierdie ideologië gehad het op die Calvinistiese spirituele fondament van Afrikanernasionalisme. Hierdie bedreigings het dikwels geskakel met populêre musiek..$^{88}$

In Suid-Afrika het die sosiale dinamika wesenlik verskil van dié van Brittanje en die VSA. In 'n sekere sin het rock-musiek uit die buiteland - dieselfde kunstenaars wat so invloedryk was, soos die Beatles en Bob Dylan - iets anders vir Afrikaners beteken. Hoewel die musiek gewild was en gespreek het tot die rebelse impulse in 'n konserwatiewe Suid-Afrikaanse samelewing, was die verwysings in die musiek (plekname, gebeurtenisse, spreektaal), maar veral ook die politiek, onbekend. Aan die begin het die rock-musiek van die 1960's'n sterk politieke posisie beklee as die stem van 'n linkse jeugkultuur wat homself verset het teen die Tories (die Konserwatiewe Party) in Brittanje en die Republikeine in die VSA, ${ }^{89}$ maar daar was nie so 'n politieke konneksie in Suid-Afrika nie. Liberalisme was nie algemeen onder Afrikaners nie. Afrikaner intellektualiteit het rondom intra-party debatte oor hervorming gedraai, of "kritiek van binne", nie anti-establishment en anti-apartheid debatte nie. ${ }^{90}$ Kampusse van Afrikaanse universiteite het gedien as akademiese kweekskole vir nasionalistiese ideologie, nie vir studente-aktivisme wat kon manifesteer in onverdraagsaamheid onder studente nie. Op 10 Oktober 1970 het 'n groot groep Afrikaanse studente by die Universiteit van Pretoria 30 konsertgangers (hoofsaaklik Engelssprekendes met lang hare) ontvoer by die Milner Park Rock-fees, die eerste van sy soort wat in Johannesburg gehou is. Hulle is na die openbare fonteine in Pretoria geneem waar 'n groot groep Afrikaanse studente reeds bymekaargekom het. Hulle is geslaan, en hulle lang hare

86 Drewett, "Packaging Desires", p. 122.

87 R. Eyerman en A. Jamison, Music and Social Movements: Mobilizing Traditions in the Twentieth Century (Cambridge: Cambridge University Press, 1998), p. 6.

88 P. McLachlan, "Die Afrikaner en die Kunste”, Handhaaf, Januarie 1974, p. 17.

89 S. Frith, "Rock and the Politics of Memory", Social Text, 9:10 (1984), pp. 60-61.

90 A. du Toit, Die Sondes van die Vaders (Kaapstad: Rubicon Press, 1983), p. 16. 
is afgeskeer. ${ }^{91}$ Die konsert het bestaan uit die top Suid-Afrikaanse rock-groepe van die tyd ${ }^{92}$ en is georganiseer deur die vervaardiger en (hoofsaaklik) country-sanger, Billy Forrest.

Gesien teen wat ter tyde aan die gang was in die res van die wêreld, het die middelklas Afrikanerjeug en hulle eweknieë in ander lande minstens 'n paar gemeenskaplike karaktertrekke gehad. Nadat die Wysigingswet op Verdediging van 1967 geproklameer is, is alle wit mans ouer as 17 jaar opgeroep vir diensplig in die Suid-Afrikaanse Weermag (SAW) (vantevore is dienspligtes aangewys deur loting). ${ }^{93}$ Dit was, ten minste gedeeltelik, wat met Amerikaanse mans gebeur het gedurende die Viëtnamoorlog - 'n katalisator vir sterk anti-oorlog protes onder studente. Hierdie sosiale bewegings was intiem verbind aan protesmusiek. As mens hierdie ooreenkomste in ag neem is dit interessant om te sien dat Afrikaanse musiek nie enige regte vorm van protes weerspieël het tot die 1980's nie.

In nog 'n ironiese wending het die SAW'n rol gespeel om die Afrikanerjeug aan nuwe subkulture bloot te stel wat andersins ontoeganklik sou gewees het vir jong wit middelklas Afrikanermans. 'n Goeie voorbeeld is die Amerikaanse sanger Rodriguez, wie se anti-establishment folk-musiek onder die troepe in die weermag versprei het. Die dokumentêr Searching for Sugar Man, ${ }^{94}$ wat 'n Oscar gewen het, onderstreep hoe sy musiek weerklank gevind het onder Suid-Afrikaners vanaf die vroeë 1970's terwyl hy geheel en al geïgnoreer is in die VSA, waar hy vandaan is. Die rolprent was 'n wêreldwye treffer en het die politiek van musiek in apartheid Suid-Afrika na 'n internasionale gehoor gebring en akademiese ondersoek tot gevolg gehad. ${ }^{95}$ In hierdie dokumentêr word hierdie gewildheid - ten spyte van die feit dat Rodriguez se musiek verban was in Suid-Afrika - gedeeltelik toegeskryf aan 'n sosiale onderstroming wat ontevrede was met die apartheidregering en wat in sy musiek 'n subtiele manier gevind het om protes aan te teken in 'n wêreld waar ander pogings brutaal stilgemaak is. Hierdie siening het fel kritiek ontlok van voormalige troepe wat beweer Rodriguez se musiek was gewild onder 'n veel breër gehoor en dat selfs die stoerste rassiste in die weermag daarna geluister het. ${ }^{96}$ Terwyl die dubbelsinnige betekenis van Rodriguez se musiek waarsku teen oorvereenvoudiging is dit geregverdig om te sê dat rock-musiek 'n stem gegee het aan ongeartikuleerde anti-establishment gevoelens onder wit Suid-Afrikaanse jongmense. Dit is sigbaar in die vorming van Engelse punk- en rock-groepe op die Oos-Rand gedurende die 1970's, soos die Radio Rats en Corporal Punishment. ${ }^{97}$ Dit is egter belangrik om te besef dat anti-establishment in Suid-Afrika gedurende die 1960's en 1970's anders was as anti-establishment in Brittanje of die VSA. Geoegrafiese isolasie - om nie eens te praat van die kulturele isolasie wat die afwesigheid van televisie in Suid-Afrika tot 1976 teweeggebring het nie - en 'n lewe onder 'n politieke (en klas-) sisteem wat merkbaar verskil het

91 The Daily News, 10 Oktober 1970, pp. 1-2; Die Burger, 12 Oktober 1970.

92 Suck, Hawk, Jacob Haye, Freedom's Children, Hocus (met Mutt Lange, wat later met Grammy-toekennings bekroon is in die VSA), Conglomerate (wat later die gewilde Rabbitt geword het met Trevor Rabin, wat onlangs in die Rock 'n Roll Hall of Fame opgeneem is vir sy werk met YES), die Otis Waygood Blues Band, Abstract Truth en 'n aantal folk-sangers soos Mike Dickman, Brian Finch, Duccio Alessandri en David Marks. Sien http:// www.3rdearmusic.com/hyarchive/hyarchive/milnerpark.html\#millpark [besoek 6 April 2017].

93 G. Callister, "Patriotic duty or resented imposition? Public reactions to military conscription in white South Africa, 1952-1972", South African Journal of Military Studies, 35:1 (2007), p. 46.

94 DVD, geregisseer deur Malik Bendjelloul (Canfield Pictures: The Documentary Company, 2012).

95 Sien J. Hyslop, "'Days of Miracle and Wonder'? Conformity and Revolt in Searching for Sugar Man”, Safundi, 14:4 (2013), pp. 490-501.

96 A. Kannemyer, "Suiker-omhulde bog", Die Burger, 13 Maart 2013.

97 P. Hopkins, Voëlvry: The Movement That Rocked South Africa (Kaapstad: Zebra Press, 2006), p. 92. 
van dié van die VSA en Brittanje, het die sosiale lewens van die Suid-Afrikaanse jeug op unieke konteks-spesifieke maniere beïnvloed.

\section{Afrikaner liberale}

$\mathrm{Al}$ het die meeste lande in die Weste 'n skerp styging gesien in intellektueel linkse organisasies gedurende hierdie tyd, was daar geen soortgelyke reaksies sigbaar onder die Afrikanerjeug nie. Afrikaners was blykbaar tevrede met hulle nuutgevonde middelklas status, wat hulle bereik het danksy die ekonomiese voordele van apartheid. Die mees radikale Afrikaner in hierdie tyd was moontlik die anti-apartheid aktivis en hoof van die verbande SAKP (Suid-Afrikaanse Kommunistiese Party), Bram Fischer. In 'n brief wat hy in Februarie 1965 aan sy verdedigingspan geskryf het, ten tyde van 'n hofsaak wat hy met opset nie bygewoon het nie, het hy die feit benadruk dat die ekonomiese groei besig was om wit Suid-Afrikaners oorgerus te maak:

Wat nodig is, is vir Wit Suid-Afrikaners om hulself los te skud uit hulle selfvoldaanheid, 'n selfvoldaanheid wat verskerp word in die huidige ekonomiese bloeityd en wat op rassediskriminasie gebou is. Tensy hierdie hele ondraaglike sisteem radikaal en vinnig verander, moet rampspoed noodwendig volg. Haglike bloedvergieting en burgeroorlog sal onvermydelik wees, want so lank as wat daar onderdrukking is van 'n meerderheid, sal daar teen sulke onderdrukking geveg word met toenemende haat. ${ }^{98}$

Die ander linkse Afrikaner-intellektuele het hoofsaaklik bestaan uit 'n groep begaafde Afrikaanse skrywers genaamd die Sestigers, onder wie die digter-aktivis, Breyten Breytenbach, die mees radikaal was. Soortgelyk aan die sensuur wat musikante moes verduur, was hierdie skrywers onderworpe aan kat-en-muis speletjies in terme van die verbanning en ontbanning van hulle werk, na gelang van die politieke klimaat:

On 29 January 1974, the first significant banning of an Afrikaans literary work, Andé Brink's, Kennis van die aand, took place, intensifying opposition to censorship from the Afrikaner intelligentsia. The result was the formation of the Afrikaner Skrywersgilde. By way of contrast, the FAK supported the legislation. In the late 1970s the works of progressive white writers such as Brink, Gordimer and Etienne Leroux were unbanned, in spite of their refusal to participate in the process, because the government wished to project a more liberal facade.99

Buite hierdie groep is Afrikaner intellektualisme in beslag geneem, nie deur anti-apartheid kritiek nie, maar deur binne-party debatte oor verandering (in lyn met Van Wyk Louw se idee oor lojale protes wat vroeër genoem is). ${ }^{100}$ Die outeur Etienne Leroux het aangevoer dat die "onortodoksie van die verstand", waar kreatiwiteit geïnspireer word, word gedemp deur die onderdrukkende staatsonderwys-sisteem. ${ }^{101}$ Mens kan miskien argumenteer dat die

98 Beskikbaar by http://www.sacp.org.za/docs/biography/2006/bramug.html [besoek 13 Maart 2013].

99 C. Merrett, A Culture of Censorship: Secrecy and Intellectual Repression in South Africa (Kaapstad, David Philip Publishers, 1994), p. 80.

$100 \mathrm{Du}$ Toit, Die Sondes van die Vaders, p. 16; Mouton, "Reform from within", pp. 149-176.

101 Merrett, A Culture of Censorship, p. 207; sien ook J. Cope, The adversary within: dissident writers in Afrikaans (Kaapstad, Philip, 1982), p. 123. 
"beweging" in die VSA beide aangewakker is deur, en plaasgevind het gedurende 'n tyd van groot sosio-politieke verandering of skommeling. Dit was in skrille kontras met wit Suid-Afrika, wat in 'n relatiewe statiese sosio-politieke periode was waarin Afrikanernasionalisme sy mag deur verdrukking gekonsolideer het. Dinge het egter geleidelik begin uitrafel van die middel 1970's af, wat 'n tyd van toenemende politieke opstoting ingelui het waartydens die mag van die Nasionale Party ondermyn is op verskeie plaaslike en internasionale fronte. 


\section{HOOFSTUK VYF}

\section{Nuwe stemme, veranderende politiek en toenemende ondermyning}

\section{Die era van televisie, Musiek-en-Liriek, kabaret, literatuur, die Grens}

Die intrede van televisie in Suid-Afrika is baie jare opgehou deur ultrakonserwatiewe nationaliste (verkramptes) soos die Minister van Pos-en-Telekommunikasie van 1958-1968, Albert Hertzog, wat 'n keer die dramatiese stelling geuiter het dat "binne die pil van televisie is daar 'n bitter gif wat uiteindelik die ondergang van beskawings sal beteken". ${ }^{1}$ Nixon het dit "die mees drastiese daad van kulturele proteksionisme in die geskiedenis van die medium" genoem. ${ }^{2}$ Hierdie proteksionisme het dieper foutlyne in die Afrikanerdom weerspieël. Vir die verkramptes sou om televisie toe te laat Suid-Afrika verder blootstel aan die invloed van die Amerikaanse kultuur wat, veral gedurende die 1960's, allerhande vreemde en moreel korrupte dinge beliggaam het. Die rasbemagtiging van die burgerregterlike-beweging, studenteopstande, hippies, anti-oorlogbetogings, vredesbewegings en die musiek wat daarmee geassosieer is - het almal 'einde van die beskawing'-emosies by meer konserwatiewe nasionaliste ontlok. ${ }^{3}$ Verwoerd was self ook daarteen gekant, en het televisie as 'n bedreiging vir "die rassestryd op wêreldskaal"

1 R. Nixon, "Apollo 11, Apartheid, and TV: When the only way to watch was to line up in front of a purple velvet curtain", The Atlantic, Julie 1999, vertaal uit oorspronklike.

2 R. Nixon, Homelands, Harlem and Hollywood: South African Culture and the World Beyond (New York: Routledge, 1994), p. 43, vertaal uit die oorspronklike.

3 R. Nixon, Homelands, Harlem and Hollywood, p. 45. 
verklaar. ${ }^{4}$ Aan die ander kant van die spektrum het meer verligte politici die voordele van beter kontak met die buitewêreld aangevoer. ${ }^{5}$

Vir die regering het die verbod op televisie strenger sosiale beheer beteken, maar dit het ook nadele gehad. Dit het selfs die onwrikbare konserwatiewes geïrriteer om nie Neil Armstrong en Buzz Aldrin se maanwandeling in 1969 te kon sien nie. ${ }^{6}$ Dit het beklemtoon hoe ver Suid-Afrika van die moderne wêreld verwyderd geraak het, 'n feit wat vir baie wat Suid-Afrika as 'n eweknie van die Westerse samelewing wou sien, onaanvaarbaar was. In 1971 het die alomteenwoordige Piet Meyer, 'n Kommissie van Ondersoek gelei om die lewensvatbaarheid van televisie vas te stel. Die uitkoms was positief, indien dit streng beheer sou word. Die eerste toetsbeeld is in Mei 1975 uitgesaai, en gereelde uitsendings het in Januarie 1976 begin. Vir Afrikaanse musiek het dit'n hele nuwe stel geleenthede ingelui. Die Afrikaanse digter en joernalis, Stephan Bouwer, se televisieprogram Fyn net van die Woord ('n verwysing na N.P. van Wyk Louw se Raka) uit 1977 was instrumenteel in die vestiging van 'n nuwe bewussyn in Afrikaanse musiek. ${ }^{7}$ Bouwer se program het getoonsette Afrikaanse gedigte onder die publiek se aandag gebring. Volgens artistieke standaarde het Afrikaanse skrywers regdeur die twintigste eeu beter presteer as hulle eweknieë in populêre musiek, met hoogs gerespekteerde bewegings soos die Dertigers ('n verwysing na die 1930's) en die meer radikale Sestigers ('n verwysing na die 1960's). Dit beteken, amper by verstek, dat die nuwe musiek se meer bekteknisvolle lirieke, 'n dieper boodskap gehad het as die Euro-kitch Afrikaanse pop wat gesing is deur "operasangers wat 'n vinnige geldjie wou maak".

Hierdie Afrikaanse populêre musiek hoofstroom is oorheers deur sangers soos Gé Korsten, Groep Twee, Jurie Ferreira en Lance James, saam met die platemaatskappy Brigadiers. Die koms van televisie en die gebrek aan plaaslike inhoud het dit moontlik gemaak vir 'n groep relatief onbekende Afrikaanse sangers om toegang tot 'n nuwe medium te kry. Een van die invloedrykste kunstenaars van dié era was Koos du Plessis, bedags 'n joernalis, maar ook 'n begaafde liedjieskrywer wat reeds in die 1960's liedjies begin skryf het (sy treffer en een van die mees geliefde Afrikaanse liedjies van alle tye, "Kinders van die wind" is byvoorbeeld reeds in 1967 geskryf). In dié sin kan Du Plessis gesien word as een van die vroegste skrywers van poëtiese Afrikaanse folk-musiek en eerder 'n tydgenoot van die Sestigers. Sy lirieke veral, het universele menslike temas behandel en dikwels gefokus op menslike feilbaarheid, maar het die politiek vermy. ${ }^{9}$ Sy musiek was dikwels nogal somber, in teenstelling met die ligte luim van die pop-hoofstroom. Sy liedjies was van die eerstes op Afrikaanse televisie toe dit deur sy vriend en vervaardiger, Nick Taylor, op Fyn net van die Woord en Musikale Mallemeule opgevoer is. Teen 1978 het Du Plessis sy televisiedebuut gemaak toe hy drie van sy eie liedjies op Perspektief gesing het. ${ }^{10}$ In 1979 het Laurika Rauch "Kinders van die wind" opgeneem vir die gewilde program

4 R. Nixon, "Apollo 11, Apartheid, and TV: When the only way to watch was to line up in front of a purple velvet curtain", The Atlantic, Julie 1999.

5 Nixon se in-diepte analise van die politiek van televisie in Suid-Afrika in die tyd is insiggewend en gesaghebbend.

6 R. Nixon, "Apollo 11, Apartheid, and TV".

7 Loots, "Die ewolusie van die Afrikaanse lied", p. 7.

8 Ibid.

9 A. Bezuidenhout, "Skielik is jy vry: Die lewe en musiek van Koos du Plessis", http://www.oulitnet.co.za/roof/roof16.asp [besoek 22 Januarie 2015].

10 K. du Plessis \& I. du Plessis: Erfdeel, (Stellenbosch: African Sun Media, 2004), pp. 15-16. 
Phoenix en Kie. Rauch het ook drie ander Du Plessis-komposisies in die reeks gesing: "Sprokie vir 'n stadskind", "Skielik is jy vry" en "Die somer is verby". ${ }^{11}$ In dieselfde jaar het sy die enkelsnit "Kinders van die wind" uitgereik, wat binne sewe weke goue status bereik het, en teen Oktober as nommer een op Radio 5 se Best sellers-program verklaar is. ${ }^{12}$ Du Plessis het ook in 1979 'n weergawe van die liedjie ingesluit op sy hoog aangeskrewe debuutalbum Skadu's teen die muur. ${ }^{13}$ Teen die tyd dat Rauch se weergawe nommer een bereik het, het nog 'n program 'n groot treffer geword, met 'n aantal kunstenaars, onder meer Rauch, Anton Goosen (wat die musiekredakteur was), Clarabelle van Niekerk, Jannie du Toit, Louis van Rensburg, Des Lindbergh, Mynie Grové en die helfte van die gewilde duo Groep Twee - Sias Reinecke. ${ }^{14}$ Die titel was Musiek-en-Liriek onder regie van Merwede van der Merwe, en die eerste uitsending was op 1 Augustus 1979. Selfs voor die eerste episode is 'n aantal Musiek-en-Liriek-konserte reeds in die Laager in die Markteater in Johannesburg gehou, met hierdie nuwe generasie Afrikaanse kunstenaars in die hoofrol. Die program was 'n treffer en het sterre van die deelnemers gemaak.

Verdere konserte, in die Markteater en in die Oude Libertas-teater in Stellenbosch, het gevolg. ${ }^{15}$ Teen dié tyd het nog kunstenaars by die span aangesluit, met onder meer 'n jong Anneli van Rooyen (wat later 'n topverkopende popkunstenaar sou word), Jannie Hofmeyr, Coenie de Villiers, Jan de Wet, Amanda Strydom en Koos du Plessis self (wat ietwat buite die hoofgroep van Musiek-en-Liriek-kunstenaars gebly het - hy het hulle gerespekteer, maar hulle het geen invloed op sy skryfwerk gehad nie ${ }^{16}$ - tot sy ontydige dood in 'n motorongeluk in Januarie 1984). David Kramer het ook in die tweede Musiek-en-Liriek-konsert in die Oude Libertas-teater opgetree. ${ }^{17}$ Goosen het kort voor hierdie konserte, ná die sukses van sy debuutalbum Boyvan die suburbs, die skuif van nie-uitvoerende liedjieskrywer na sanger gemaak.

Joernalistehet in diétyd entoesiastiesgereageer op hierdie onderbrekingin dienie-konfronterende lekkerliedjies van die Afrikaanse pop-hoofstroom en die invoer van die luisterliedjie - 'n Hollandse woord vir liedjies waarvan die lirieke 'n dieper betekenis het. ${ }^{18}$ Nog 'n gevolg van 'n verskyning op televisie was die nasionale blootstelling. Voorheen was daar 'n groter gevoel van provinsialisme onder Afrikaanse sangers. Wat in die Kaap gebeur het, het nie noodwendig by Pretoria uitgekom nie, en omgekeerd. Deur middel van televisie het kunstenaars wat dalk onafhanklik van mekaar gewerk het skielik 'n breër verwysingsraamwerk en respek gehad vir waarmee ander Afrikaanse liedjieskrywers en sangers besig was. ${ }^{19}$

11 Ibid.

12 Ibid., p. 16.

13 Ibid.

14 M. Jamneck, "Jana se 'sangstem' is nie onder maatemmer", Die Vaderland, 16 Julie 1979, p. 2.

15 Anton Goosen, onderhoud met outeur, Gansbaai, 29 April 2013.

16 A. Bezuidenhout, "Skielik is jy vry: Die lewe en musiek van Koos du Plessis".

17 Slabbert en De Villiers, David Kramer, p. 139.

18 R. Loots, "Die ewolusie van die Afrikaanse lied, of, totsiens aan 'kom-bly-by-my ... moenie weggaan'-musiek" Die Transvaler en Oggendblad, Junie 1979, p. 7; M. Jamneck, "Jana se 'sangstem' nie sonder maatemmer”, Die Vaderland, 26 Julie 1979, p. 2; J. Bruwer, "Sy skeur bittersoet uit mens se hart”, Rapport Ateljee, 9 September 1979, p. 1; S. Bouwer, “En hoor jy die magtige dreuning?”, Rapport Ateljee, 9 September 1979, p. 6.

19 Laurika Rauch, telefoniese onderhoud met outeur, 25 Julie 2013. 

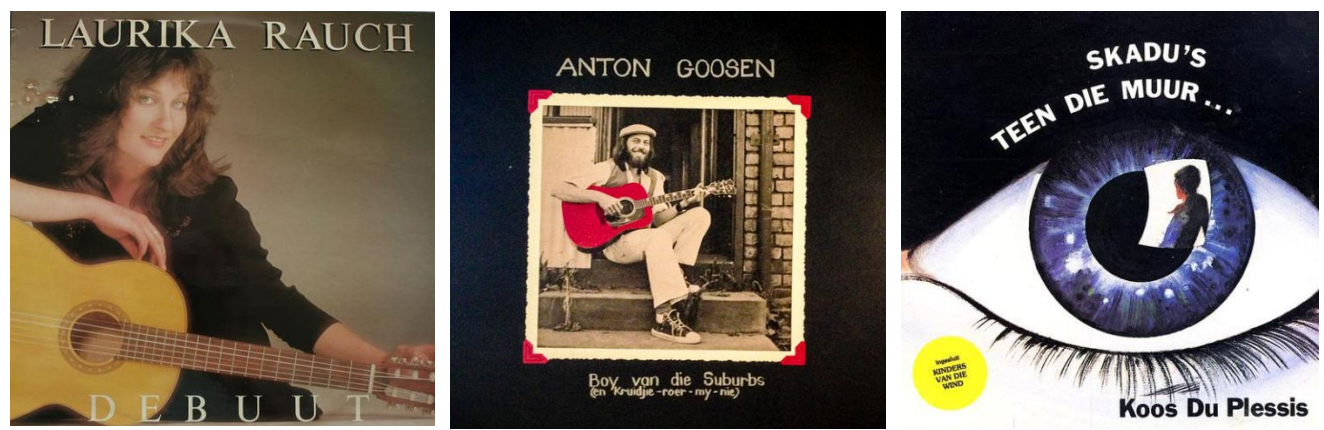

Drie belangrike vrystellings in 1979 - 'n groot jaar vir Afrikaanse musiek: Laurika Rauch se Debuut (RPM I I 37), Anton Goosen se Boy van die Suburbs (RPM I I 30) en Koos du Plessis se Skadu's teen die muur (Warner Brothers WBC 9010).

Hoewel die kunstenaars oënskynlik nie eksplisiet in die politieke stryd met die establishment betrokke was nie, het subtiele politieke inhoud af en toe in die folk-ballades opgeduik. Des Lindbergh het opgemerk dat dit "neo-folk in Afrikaans [was]! Sewentien jaar nadat dit in Engels gebeur het." ${ }^{20}$ Die skrywer, digter en liriekskrywer Rosa Keet, wat die aanvanklike Musiek-en-Liriek konserte by die Laager georganiseer het, was baie optimisties oor die toekoms van die nuwe Afrikaanse musiek:

Landwye toere, op die platteland en ook in bruin en swart woonbuurte. Borge vir nuwe plaatopnames, die publisering van bladmusiek, 'n sangfees wat oop is vir alle bevolkingsgroepe om nuwe liedjies bekend te stel, die studie van inheemse volksmusiek aan ons Toonkunsakademies ... 'n TV-kompetisie vir nuwe liedjies ... en stuur die wenners na 'n internasionale sangfees!'21

Haar ambisie om dit na bruin en swart gehore te neem was in dié tyd veelseggend, en weerspieël 'n liberale houding, hoewel dit onduidelik is hoe ander kunstenaars daaroor gevoel het.

Die aanvanklike momentum het gou opgedroog en die kunstenaars het almal hulle eie koers ingeslaan, maar die ontploffing van gewilde Afrikaanse liedjies was skielik baie ryker en minder oppervlakkig. Veral Du Plessis se werk het stand gehou en verskeie weergawes daarvan is later deur allerlei kunstenaars opgeneem. Johannes Kerkorrel het in 1999 'n hele album met sy liedjies, Johannes Kerkorrel Sing Koos du Plessis gemaak, terwyl sowel Theuns Jordaan as die industriële groep Battery 9, weergawes van "Koue vuur" uitgebring het. Die Afrikaanse rock-groep Van Coke Kartel het 'n weergawe van Skadu's teen die muur opgeneem en in 2010 'n video daarvan uitgereik. ${ }^{22}$ Van sy werk het selfs in die Nederduits-Gereformeerde Kerk (NGK) se sangbundel beland. ${ }^{23}$ Teen 1983 het Rauch die beweging wat haar bekend gemaak het agter gelaat:

Today, luisterliedjie is a bit of a swearword. The records are still being made - and they are still not selling. The movement has burrowed underground in order to protect itself. ... When I started out I felt obliged to show the public how serious

20 S. Bouwer, “En hoor jy die magtige dreuning?", Rapport Ateljee, 9 September 1979, p. 6.

21 Ibid.

22 A. Bezuidenhout, "Van Coke bo die grond roep na Koos onder die grond", Versindaba blog, beskikbaar by http:// versindaba.co.za/tag/skadus-teen-die-muur/ [besoek 21 Maart 2017].

23 Ibid. 
I was. I didn't want to waver, to diversify at all, only to refine my art. ... But I have had my say. It was a privilege to be on the crest of that wonderful wave, and I have three albums that stand as legacy should anyone be interested. ${ }^{24}$

Hierdie "wonderlike golf" was simptomaties van 'n fundamentele houdingverandering in Suid-Afrika.

\section{Wyer verandering op die politieke front}

Voor die laat 1970's het Afrikaners selde die legitimiteit van apartheid bevraagteken, maar mettertyd het 'n wyer kring kritiese stemme begin om ernstige vrae te vra oor die morele basis van "kritiek van binne", waarvan die digter N.P. van Wyk Louw en joernaliste Piet Cillié en Schalk Pienaar vroeë verteenwoordigers was. ${ }^{25}$ Sulke kritiek was meer begaan met hervormingstrategieë as om die legitimiteit van die apartheidsprojek in sy geheel te ondermyn. $\mathrm{Du}$ Toit argumenteer dat hierdie posisie teen die laat 1970's onuithoudbaar geword het vanuit 'n morele perspektief, en dat 'n volgehoue fokus op die Afrikaner se politieke oorlewing uiteindelik sy tol sou eis op die Afrikanerkultuur. ${ }^{26}$ 'n Aantal politieke gebeurtenisse in die 1970 's, wat al uitgebreid beskryf is, het gelei tot 'n leierskapkrisis in die regerende NP en tot die opkoms van 'n nuwe golf kritiese Afrikaner stemme. Die Soweto-opstand in 1976, die 1977 wapenverbod, Steve Biko se dood aan die hande van die veiligheidspolisie in dieselfde jaar, ${ }^{27}$ en die Inligtingskandaal van 1978 (wat gelei het tot die uittrede van B.J. Vorster as Eerste Minister) het harde klappe aan die regime uitgedeel. Die internasionale druk wat daarop gevolg het, die Grensoorlog en die opkoms van die Swart weerstandsbewegings vanaf die mid-1970's, het die krisis vererger. Die feit dat dit alles gebeur het in die nuwe era van televisie het Afrikaners ingelig oor wat in die land aan die gang was en wat namens hulle bedryf is. ${ }^{28}$ Saam met die einde van 'n drie-dekades-lange periode van hoë ekonomiese groei gedurende die mid-1970's, ${ }^{29}$ het dit die apartheidsregime se mag ondermyn.

P.W. Botha, wat Vorster in September 1978 opgevolg het, het 'n "adapt or die"-strategie ingevoer, wat gebaseer was op beperkte hervorming, maar nie die opgee van die apartheidstelsel nie. Botha "het Suid-Afrika soos 'n storm getref" ${ }^{30}$ Hy het hoop op hervorming gebied, maar 'n wrede strategie ingevoer wat ontwerp was om die NP ten alle koste te laat oorleef. ${ }^{31}$ Onder Botha se nuwe strategie het die staat kritiek minder goed geduld en sensuur is verskerp. 'n Groot vermeende gevaar wat die staat bedreig het, was die aanval van kommunisme op die Suid-Afrikaanse samelewing. Hierdie persepsie is gewortel in die geo-politiese agtergrond van die Koue Oorlog, die sterk sosialistiese teenwoordigheid in onafhanklike Afrika-state, die SAW se konflik met die

24 R. Dean, "Rauch - a new direction", The Star, 1 November 1983, p. 6.

25 André du Toit, Die sondes van die vaders, (Kaapstad: Rubicon Press, 1983), pp. 16-17; Van der Westhuizen, White Power \& the Rise and Fall of the National Party, p. 86.

26 Du Toit, Die sondes van die vaders, p. 9.

27 C. van der Westhuizen, White Power \& the Rise and Fall of the National Party (Kaapstad: Zebra Press, 2007), p. 296.

28 H. Giliomee, Die Afrikaners: 'n Biografie (Kaapstad: Tafelberg, 2003), p. 580.

29 Ibid., p. 597.

30 Ibid.

31 Hopkins, Voëlvry, p. 54. 
kommunisties-gesteunde magte in Angola, en die verband tussen die anti-apartheid-bewegings en sosialisme. Presies hoe realisties dié gevaar was, is omstrede, maar in die tyd is dit gesien as 'n 'totale aanslag' wat deur 'n 'totale strategie' teen ondermynende elemente geneutraliseer moes word. ${ }^{32}$ Terwyl die Afrikaners in die 1960's in 'n land gewoon het waar hulle heer en meester was - 'n posisie wat God bepaal het en deur patriotiese ideoloë bestuur is - het dit teen die mid-1980's 'n persoonlike stryd om oorleweing geword. Die opleiding van wit mans om teen kommuniste te veg het so 'n direkte afdeling van oorlewing van die wit Suid-Afrikaner geword. In Julie 1985 het Botha 'n noodtoestand aangekondig weens burgerlike onrus en geweld in die townships - aanvanklik beperk tot dele van die Oos-Kaap en die Witwatersrand, maar dit het later landswyd uitgebrei - wat tot 1990 geduur het. Wit troepe is in die townships ingestuur en die Suid-Afrikaanse samelewing het nog meer verpolitiseer en verdeeld geraak onder die groeiende veroordeling van apartheid. Afrikaner steun vir die NP en selfs die NGK - vir jare 'n onontbeerlike steunpilaar van Afrikanernasionalisme wat rasseskeiding regverdig het - het weggebreek van die leerstelling van apartheid. ${ }^{33}$ Terwyl dit gebeur het, het baie Afrikaners ook polities na regs beweeg. 'n Groeiende konserwatiewe groep in die NP onder Andries Treurnicht, het in 1982 gelei tot die vorming van die weggebreekte Konserwatiewe Party, wat 'n teken was van die "einde van die Afrikanernasionalistiese eenheid". ${ }^{34}$

Terwyl die leiende magte van die Afrikaner nasionalistiese establishment uitmekaar begin val het, het Afrikaanse kunstenaars begin om kritiek teenoor die politieke stelsel uit te spreek, hoewel 'n uit-en-uit veroordeling van apartheid steeds seldsaam was. Nuwe temas het hulle opwagting gemaak, soos grensliteratuur, wat afgespeel het op die toneel van die Grensoorlog. ${ }^{35}$ Teen dié agtergrond gesien het Musiek-en-Liriek op 'n deurslaggewende oomblik gebeur: net nadat Botha die mag oorgeneem het (met 'n sprankie hoop op hervorming), maar voor die politieke geweld van die mid- tot laat-1980's. Party Afrikaanse kunstenaars het op hierdie dramatiese sosiale veranderinge gereageer, wat gelei het tot die vorming van los gegroepeerde "bewegings" in die letterkunde, teater en musiek. In die geval van Afrikaanse musikante was hierdie soort mobilisering duidelik afwesig in die voorafgaande dekades. ${ }^{36}$ Hierdie reaksies was aanvanklik subtiel en tentatief, aangesien die Afrikaner-samelewing nog baie konserwatief en die sensuurraad baie liggeraak was. Nietemin is dit geregverdig om te sê hoewel die eerste impak van Musiek-en-Liriek weggesak het, die kommersiële Afrikaanse mark meer divers was, met nuwe stemme en nuwe genres. Die kunstenaars wat die beste verkoop het was steeds egter mense soos Bles Bridges en Gé Korsten.

Anton Goosen was miskien die primêre protagonis van Musiek-en-Liriek. Op'n konsertprogram vroeg in 1980 is hy beskryf as "die vader van die Afrikaanse chanson", wat dan in Afrikaans vertaal is as luisterliedjie, en "ons eie folk-musiek" in Engels. ${ }^{37}$ Soos Raeford Daniel verduidelik:

32 Giliomee, Die Afrikaners, p. 588, in verwysing na 'n 1977 Witskrif deur die Departement van Verdediging uitgereik toe Botha die Minister van Verdediging was.

33 Giliomee, Die Afrikaners, p. 620.

34 Ibid., p. 603; sien ook Van der Westhuizen, White Power \& the Rise and Fall of the National Party, p. 296.

35 'n Noemenswaardige voorbeeld is Alexander Strachan se ' $n$ Wêreld sonder grense van 1983.

36 Veral wanneer mens die oorvloed van sulke bewegings in die Weste in ag neem.

37 R. Daniel, “'Folk' - or a fine anomaly”, Rand Daily Mail, 22 Januarie 1980, vertaal uit die oorspronklike. 
Now as any South African knows, a folk song is not necessarily a "volkslied". The Afrikaans term could be understood as meaning a "national song"; even, more specifically, a national anthem. It could also, in a more colloquial sense, signify a song of the "volkies", a term once applied affectionately to black or coloured servants or tenant farmers. Equally, one recognises, the contemporary folk song, as exemplified by the Folk Revival of the Sixties, was held suspect by the conservative Afrikaner ... The curiosity - and the miracle - is that, appealing (and appropriate) as the term, "luisterliedjies" may be, Goosen's work could fit any of the above definitions of the term "Folk". It is national in that it has its roots in the musical traditions of the Afrikaner (a fact which attains an ambivalent acknowledgement most particularly when he is sending them up). It is colloquially "folk" in that it draws its inspiration from the people - all shades of the people. And it is "contemporary folk" in that, in both idiom and content, it is very much geared to what is happening here and now. ${ }^{38}$

Die beskrywing is akkuraat, maar beklemtoon ook die feit dat kunstenaars wat met Musiek-en-Liriek geassosieer is, baie nuwe idees oor Afrikaanse musiek verteenwoordig het: ondermynende politiek, verskillende "folk" genres, Afrikaanse rock, intellektualisme, poësie en teenkultuur.

Goosen se deurbraak in 1979 het nie noodwendig te make gehad met die Musiek-en-Liriek-program nie. Hoewel hy betrokke was as die musiekredakteur van die program, was sy debuutalbum, Boy van die suburbs, al op die rakke teen die tyd dat die program uitgesaai is en die eerste enkelsnit, "Kruidjie roer my nie", was op die trefferparade. Tussen 80000 en 90000 kopieë van die plaat is voor die einde van daardie jaar verkoop. ${ }^{39}$ Hoewel die meeste Musiek-en-Liriek-kunstenaars weggeskram het van die politiek, het twee van Goosen se liedjies, "Mpanzaville" en "Atlantis", subtiele maar onmiskenbare politieke kritiek teenoor die regime bevat in die tyd toe P.W. Botha se totale strategie teen sulke elemente net momentum begin kry het. ${ }^{40}$ Albei liedjies is deur Laurika Rauch op haar debuutalbum, Debuut, opgeneem. In "Mpanzaville" verwys die lirieke na die boosaardige "krokodil" (Botha se bynaam) wat uiteindelik deur die bewoners van Mpanzaville ('n buurt van Soweto) geslag word:41

Hartlam loop en gryp 'n klip, slaat sy kop dat hy wil stik

Sy oë tol om en om, ons slag hom af en vat sy vel

Die honde blaf die mense draf, die kraal is van vreugde stil.

In "Atlantis" rou die verteller oor die gedwonge hervestiging uit waarskynlik Distrik Ses en oor die sterwende kinders in die ghetto's van Kaapstad: ${ }^{42}$

Laat die met woorde dan skryf, en die met note dan sing

In die ghetto's, die nuwe, nuwe ghetto's, daar sterf onse kinders.

\footnotetext{
38 Ibid.

39 Onderhoud met outeur, Gansbaai, 29 April 2013.

40 Giliomee, Die Afrikaners p. 588.

41 Gallo Music Publishers.

42 Ibid.
} 
Goosen bevestig dat politieke boodskappe subtiel moes wees, omdat die uitreiking van musiek streng beheer is:

Dis waar. Dit geld vir die musiek ook. Want hier was reëls. Jy kon nie op die radio kommersiële name soos Coca Cola gebruik nie. Jy kon nie verwys na seks nie. Godsdiens was 'n taboe en politiek was 'n taboe. En dis hoekom goed, soos Mpanzaville, verskuil moes wees. Die oomblik as jy buite dit beweeg het, soos Roger Lucy, het hulle begin om jou telefoonlyn te tap. ${ }^{43}$

Anton Goosen is anders as die ander kunstenaars wat met Musiek-en-Liriek geassosieer word, want hy het 'n rigting in die Afrikaanse musiek verteenwoordig wat wit Afrikaner leierskap meer direk ondermyn het. Hy onthou hoe hy die establishment op vele maniere teëgewerk het:

In '79, '80 het die ATKV my verbied van hulle verhoë af omdat ek grappies oor die landsvlag gemaak het. En die spesifieke grappie was omdat hierdie skole waar jy optree, was daar altyd 'n foto van die president aan die een kant en dan die landsvlag aan die ander kant. En ek het, by een of ander verhoog - by Unisa of iets - hier iets oor dit kwytgeraak en grappies gemaak oor dit. In Reitz het 'n oom in die voorste ry ... toe ek Begrafnis in Zeerust doen, en die ou staan in die voorste ry op en sê 'Die Afrikaner is nie so nie' en hier kom hy vorentoe ... Dit gooi jou. Dit gooi jou. And it is just a song. Dis iets wat iemand my vertel het wat in Zeerust gewerk het. ${ }^{44}$

Die sensuurraad het gemengde taal in liedjies afgekeur, veral in die titel van 'n album, soos in Boy van die Suburbs. Die feit dat dit 'n realistiese verwysing was na alledaagse spreektaal is deur kulturele opsigters soos die FAK geïgnoreer, wat dui op die gaping tussen die Afrikaner elite en die meerderheid van Afrikaners. David Kramer is nog 'n belangrike kunstenaar wat ook met die sensuurraad gebots het omdat hy 'n gemengde ras- en taalvorm in sy musiek gebruik het. ${ }^{45}$

I suppose the most political thing I did in my work was not the content but the from. Political messages are sought in the content and there is a lot of innuendo and politics but the really radical stuff was in the style and form. ${ }^{46}$

Kramer se styl, 'n baie gewilde vorm van plattelandse musiek is beïnvloed deur die bruin kultuur, dit het sterk afgesteek teen die aanvaarde beeld van populêre Afrikaanse sangers. ${ }^{47}$ Kramer beskryf dié styl so:

... a style of singing that was obviously not white and a way of playing the guitar that was influenced by farm music. My purpose was to pull together South African influences into a kind of melting pot that would form a South African sound. Now when Johnny Clegg does it, its all very obvious to people. When a white man sings Zulu, it's obvious. When a white man sings Afrikaans, it's not. When I started it was the time of the hugely popular Afrikaans singers Gé Korsten and Sonja Heroldt.

43 Gansbaai, 29 April 2013.

44 Ibid.

45 http://www.3rdearmusic.com/lyrics/drywine.html [besoek 29 April 2013].

46 J. Roup, Boerejood (Auckland Park: Jacana Media, 2004.), p. 161.

47 Ibid. 
And that kind of Afrikaans, it was "Omo Afrikaans" - whiter than white. ... Then came two fresh voices. The one was Anton Goosen and the other was me.48

In die lirieke van "Mpanzaville" en "Atlantis" is die politieke trant duidelik. Wat meer is, die eerste-persoons verteller in "Atlantis" is bruin, soos ook die geval is in David Kramer se liedjies "Botteltjie Blou" (wat verwys na die drink van blou brandspiritus, gewoonlik deur haweloses) en "Skipskop", wat 'n doelbewuste empatie vir die "ander" ras inset. Ondanks sy sukses as 'n liedjieskrywer het Goosen 'n ongemaklike verhouding met die Afrikaner establishment gehad. Die volgende uittreksel uit 'n onderhoud met Goosen lewer roerend kommentaar op hoe die Musiek-en-Liriek kunstenaars deur die konserwatiewe Afrikaner establishment beskou is:

In die middel van hierdie Musiek-en-Liriek hoogtepunt het the powers that be - Bennie Bierman wat hoof was van Afrikaanse musiek op televisie en radio, en kyk, die FAK se kantore, en die Broederbond se kantore was altwee daar by Die Eike, en Brigadiers, Brigadiers Films. Sommer als onder een hoed. ... Nou "Kruidjie" gaan nou op die charts, nou kom Boy van die Suburbs uit, en die hele album, dit verkoop 'n kakhuis vol - 90 000, daai tipe ding - en danksy dit kan ek nou hier met jou gesels en weet jy wie ek is, daai vibe. The powers that be besluit toe dis tyd dat Anton bietjie afgebring word grond toe. Nou ons het 'n symposium. Nou wat doen die Afrikaner? Jy gaan mos en jy gaan dissect hierdie hele ding en haal dit uitmekaar uit en kyk waar jy kan fout vind. So dis 'n simposium toe nou oor hierdie nuwe musiek. En Hennie Aucamp word genooi om te praat oor kabaret, Laurika word genooi om oor die uitvoerende deel van kabaret en Musiek-en-Liriek en Afrikaans te praat. Ek word genooi om te praat ..., grootliks oor "maak vrede met rock". Maar intussen agter my rug ... het hulle besluit dat Anton moet teruggebring word grond toe, want dinge ruk nou hand uit. En hulle kry toe nou vir Hennie Aucamp en vir Bennie Bierman om voordat ek my speech doen, kom hulle en lewer kritiek op my. En Bennie Bierman het toe sy tyd spandeer om te sê dat "Waterblommetjies", die aksent is verkeerd. Dat "Waterblommetjiiiiieeeees in die Boland", dit moet eintlik dan wees "Waterblommetaaaas in die Boland". En dit was sy main issue gewees. En Hennie Aucamp het toe gesê dat geografies is die song nie korrek nie ... En nadat hulle toe nou hulle fanfare gedoen het, het ek toe die kans gekry om hulle eers te antwoord, en toe kon ek my speech doen. En toe het ek vir Bennie Bierman net gesê ek gee nie 'n hoot om waar die aksent lê nie, jy weet. 80000 mense het die covers van die song nou al gekoop en vir my is dit heeltemal goed genoeg, baie dankie ... Hennie het vir my gesê sorry, hy was voorgesê om hierdie ding te doen en (my) bietjie grond toe te bring. ${ }^{49}$

Hierdie soort reaksie van die establishment was nogal tipies, te oordeel na die aantal FAK simposia oor Afrikaanse musiek regdeur die afgelope vier dekades. Interessant genoeg kom Goosen se naam, ondanks die feit dat sestien van sy liedjies in die 2012-uitgawe van die FAK-sangbundel opgeneem is, nie voor op die lys van Musiek-en-Liriek-pioneers nie, ${ }^{50}$ wat 'n mens laat wonder of sy teenstrydige verhouding met die organisasie nie op een of ander manier voortgeduur het nie.

\footnotetext{
48 Ibid.

49 Anton Goosen, onderhoud met outeur, Gansbaai, 29 April 2013.

50 FAK Sangbundel, Vol. II, p. 3.
} 
Boy van die suburbs het sterk rock-elemente en Goosen is al onder andere die vader van Afrikaanse rock genoem. Dit sou ongetwyfeld bygedra het tot sy ongewildheid by konserwatiewe Afrikaners. Ironies genoeg het die rock-elemente in sy musiek toevallig ontstaan:

Met "Blommetjie gedenk aan my", ek het nie gaan sit en dink ek gaan nou die eerste rock plaat (in Afrikaans) maak nie. Se moer. Chris Kritzinger, my producer, het in die studio gesê vir die drommer: "Think baby come back". Onthou jy die song? Ta ta ta dum tak. So daar't ons die ritme wat toevallig nou rock is. En dis toevallig 'n rock riff. ${ }^{51}$

Terwyl "Blommetjie gedenk aan my" duidelik 'n rock-liedjie was, was "Kruidjie roer my nie" (die eerste treffer op die plaat) nie, wat aandui dat 'n mens versigtig moet wees om die rock-elemente van daardie tyd in sy musiek oor te beklemtoon.Videomateriaal van 'n konsert in 1980 wys egter hoe Goosen se konserte vinnige en harde verwronge kitaarsolo's bevat het, met gillende aanhangers - alles elemente wat met rock-musiek gepaardgaan en wat Goosen duidelik aangegry het en mee geasosieer is. ${ }^{52}$ Daar was vroeër al kunstenaars wat Afrikaanse rock gespeel het - soos The Bravados, The Hobos en The Bats, maar Goosen se styl en optredes was 'n baie meer realistiese weergawe van die rock-etiek van rebellie. Hy het nie daarvan weggeskram om met die sensuurraad, die FAK, die SAUK en die establishment in die algemeen te bots nie, en het dus die banaliteit blootgelê van die reëls wat tot en met daardie tyd aan die Afrikaanse kultuurindustrie opgelê is. Goosen sou ook instrumenteel wees in die sukses van ander kunstenaars wat meer direk voordeel getrek het uit Musiek-en-Liriek. Hy was verantwoordelik vir dertien liedjies op Danie Pretorius se lys van die 100 grootste Afrikaanse liedjies, ${ }^{53}$ (meer as enige ander Afrikaanse liedjieskrywer), waarvan Carike Keuzenkamp twee gesing ${ }^{54}$ het en Sonja Herholdt ses. ${ }^{55}$

\section{"Beweging"?}

Maar tot watter mate was Musiek-en-Liriek 'n "beweging"? Eyerman en Jamison definieer sosiale bewegings as "sentrale bewegings in die hervestiging van kultuur" ${ }^{56}$ Hulle is beïnvloed deur Herbert Marcuse, wat die estetiese dimensie van die sosiale bewegings van die 1960's beklemtoon, en hulle ondersoek die manier waarop die musikale deel van sosiale bewegings as 'n "kognitiewe praktyk" funksioneer, dit wil sê 'n manier om verskillende elemente binne 'n nuwe kennis te organiseer. ${ }^{57}$ Het Musiek-en-Liriek deel uitgemaak van en verbande gelê met 'n breër bewussyn in die bestaande orde, en indien wel, hoe het hierdie nuwe bewussyn en nuwe identiteit in die musiek gemanifesteer?

51 Goosen, Gansbaai, 29 April 2013.

52 https://www.youtube.com/watch?v=14evw09Z3jY [besoek 12 Desember 2014].

53 D.C. Pretorius, Musieksterre Van Gister En Vandag: lewensketse en foto's van meer as 100 musieksterre (Pretoria: Van der Walt, 1998), pp. 271-275.

54 "Byeboerwa" and "Hoeka Toeka".

55 "Hanoverstraat", "Harlekyn", "Jantjie”, "Straattroebadoere”, “Tant Mossie se sakkie-sakkie boeredans" en "Waterblommetjies".

56 R. Eyerman en A. Jamison, Music and Social Movements: Mobilizing Traditions in the Twentieth Century (Cambridge: Cambridge University Press, 1998), p. 6.

57 Ibid., pp. 6-7. 
Dit lyk of daar aanvanklik 'n teësin was om hierdie nuwe Afrikaanse musiek 'n "beweging" te noem. Rauch sê dat daar aanvanklik nie enige gevoel van samehorigheid soos by 'n beweging as sulks was nie. David Kramer deel dié mening:

\section{I am quite sceptical about labels like "alternatiewe beweging" [alternative movement]. They are usually invented by journalists for their own convenience and don't serve to inform our understanding of the creative thrust of the individuals involved. Usually the people who are collectively described as a "beweging" [movement] had not idea they were part of it until it gets described in the media as such. ${ }^{58}$}

Kramer deel hier twee belangrike insigte: eerstens, die rol van joernaliste in die skep van "bewegings", dikwels sonder die medewete van die kunstenaars wat daarmee geassosieer word en tweedens, dat hierdie konstruksie gemaak word sonder om die kunstenaars volledig as kreatiewe individue in ag te neem. Sommige joernaliste, soos Stephan Bouwer, het in die tyd ook belangrike kulturele rolle vervul. Rauch was selfs huiwerig om dit "nuut" te noem. ${ }^{59} \mathrm{Om}$ deel te wees van 'n spesifieke beweging, of onderworpe aan die eise daarvan, was duidelik nie vir haar 'n aantreklike vooruitsig nie. Dit was waarskynlik die rede waarom Rauch wegbeweeg het van die luisterliedjie teen die tyd toe haar vierde plaat in 1983 bekendgestel is. Party kommentators verkies om dit 'n "vernuwing van die Afrikaanse liedjie" ${ }^{0}$ te noem, terwyl ander nie geskroom het om dit 'n "oplewing" te noem nie. ${ }^{61}$ Mettertyd het Musiek-en-Liriek se aansien gegroei. Die 2012 FAK-sangbundel aanvaar dit nie net as 'n bona fide beweging nie, maar erken dit ook vir "die lê van die fondamente vir die ontploffing in Afrikaans musiek in die volgende dekades". ${ }^{2}$ Pat Hopkins verwys na dié fase as " $n$ klein revolusie in die hoofstroom van Afrikaanse musiek".63

Afrikaanse musiek is gedurende die twintigste eeu aan baie min akademiese ondersoek onderwerp, wat skerp afsteek teen die aandag wat gewy is aan die Afrikaanse letterkunde. Literêre kritiek was in die 1980's beter toegerus, onderskryf en geposisioneer om sinvol betrokke te wees by 'n opkomende generasie skrywers bekend as die Tagtigers ('n verwysing na die 1980's). Brekfis met vier (in 1980 gepubliseer) was byvoorbeeld 'n digbundel deur vier van hierdie prominente jong skrywers: André le Roux du Toit (ook bekend as André Letoit, wat later sy naam na Koos Kombuis verander het), Etienne van Heerden, Daniel Hugo en Peter Snyders. Teen dié tyd was daar al 'n aansienlike hoeveelheid kritiese literatuur oor die verskillende Afrikaanse literêre bewegings van die twintigste eeu, veral die Dertigers, Veertigers en Sestigers. Hoewel hierdie verdeling volgens dekade ietwat lomp bly en aan kritiek onderhewig is, het dit 'n konvensie geword. ${ }^{64}$ Andries Bezuidenhout vergelyk Musiek-en-Liriek meer met die Dertigers en Veertigers, en Voëlvry met die meer radikale Sestigers. ${ }^{65}$ Hierdie standpunt het sy meriete, aangesien Voëlvry beslis meer radikaal was as Musiek-en-Liriek, net soos die Sestigers meer

58 D. Kramer, http://www.oulitnet.co.za/mond/kkramer.asp [besoek 5 Junie 2013].

59 Jamneck, “Jana se 'sangstem' nie sonder maatemmer”, Die Vaderland, 26 Julie 1979, p. 2.

60 Bouwer, "En hoor jy die magtige dreuning?", p. 6.

61 K. Breytenbach, “Ons musiek skielik is byderwets”, Die Burger, 27 February 1980.

62 Federasie van Afrikaanse Kultuurvereniginge, FAK-Sangbundel, Vol. II, (Pretoria: FAK, 2012), p. 3.

63 Hopkins, Voëlvry, p. 56.

64 E. Botha en P.H. Roodt, "Die Tagtigers en die Tydskrif vir Letterkunde - was daar 'n Tagtigerbeweging?", Tydskrif vir Letterkunde, 43:1 (2006), pp. 57-58.

65 Bezuidenhout, "Skielik is jy vry”, Oulitnet, 2 Maart 2004. 
radikaal was as die Dertigers en Veertigers. O’Meara wys die ironie daarvan uit, dat hoewel die Sestigers aanvaarde konvensies van die "amptelike" Afrikaanse kultuur deurbreek het en dikwels skerp kritiek teen Afrikanernasionalisme uitgespreek het, het dit Afrikaans (en Afrikaanse kultuur) na nuwe hoogtes verhef, presies een van die doelwitte van die establishment wat hulle gekritiseer het. In teenstelling hiermee het Voëlvry nie suiwer Afrikaans gebruik nie - dit het probeer om die hele Afrikaner kulturele projek te ondermyn. ${ }^{66}$ 'n Dekade vroeër het die Tagtigers naas Musiek-en-Liriek opgekom, wat mense uitgelok het om ooreenkomste tussen dié twee groepe te soek. Die Tagtigers se status as 'n ware literêre beweging is egter ernstig bevraagteken deur niemand minder nie as Etienne van Heerden:

... 'die Tagtigers' was nie 'n literêre generasie in die ware sin van die word soos wat Dertig en Sestig dit was nie. Daarvoor steun die sogenaamde Tagtigerskrywers te swaar op die temas en verteltegnieke van 'n ouer geslag. Hulle het die dinge wat Aucamp, Brink, Abraham de Vries, Haasbroek, Elsa Joubert, Weideman en ander gedoen het, verder gevoer en binne 'n postmoderne sfeer geradikaliseer ... Tagtig was 'n radikalisering eerder as 'n skoon breuk met die verlede. En 'n snuf in die neus van wat voorgelê het. ${ }^{67}$

Van Heerden se mening word deur Botha ondersteun, wat meen dat hoewel daar geen ware Tagtiger-beweging was nie, daar wel 'n beweging in die 1980's was. ${ }^{68}$ Anders as die Tagtigers het Musiek-en-Liriek wel iets nuut gebied wat dit onderskei het van wat voor dit in Afrikaanse musiek gebeur het. Musiek-en-Liriek kunstenaars het soms in dieselfde kringe as die Tagtigers beweeg, maar hulle werk het selde oorvleuel. Party Musiek-en-Liriek kunstenaars het egter gedigte van die Sestigers getoonset, soos Laurika Rauch wat 'n musikale weergawe van Ingrid Jonker se "Toemaar die donker man" op Fyn net van die woord opgevoer het. ${ }^{69}$ Rauch het in die jare daarna 'n aantal van Jonker se gedigte getoonset, maar ook vroeër Afrikaanse digters wat met die Dertigers geassosieer is. ${ }^{70}$

Afrikaanse teater het soortgelyke ontwikkelinge deurgemaak. Afrikaanse toneelskrywers en skrywers van die tyd is beïnvloed deur Westerse/Europese kuns. Die meeste van hulle het 'n tersiêre opleiding geniet en van die universiteit na die verhoof of die tikmasjien beweeg. In wese het hulle dít bereik wat die kulturele entrepreneurs van apartheid nog altyd wou hê: Afrikaanse kuns geskep binne die kontemporêre tradisies van Wes-Europa. Ironies genoeg het hierdie hoogsopgeleide elite 'n slag daarvoor gehad om argetipiese Afrikaner-identiteite venynig te ondervra en dekonstrueer, en hulle te herplaas in postmodernistiese scenarios. In die woorde van Deon Opperman:

What is Reza de Wet's Diepe Grond (Deep Earth) if not an iconoclastic and devastating (especially for Afrikaners) protest play, not against Apartheid, but against Calvinism and conservatism in the Afrikaner family??

66 D. O’Meara, Forty Lost Years: The apartheid state and the politics of the National Party, 1948-1994 (Johannesburg: Ravan Press, 1996), pp. 370-371.

67 E. van Heerden, “Vier Tagtigers hou Brekvis ... en jy’s genooi!”, Insig, Maart 2005, p. 59.

68 Botha en Roodt, "Die Tagtigers en die Tydskrif vir Letterkunde”, pp. 57-58.

69 http://www.laurikarauch.com/biografie/2/ [besoek 9 Februarie 2015].

70 Soos I.D. du Plessis en Boerneef.

71 D. Opperman, "Revolution and conscience: South African theater, June 1976 to February 1990", Program vir Afrika-studies, Noordwes Universiteit, 1993, pp. 14-16, beskikbaar by http://quod.lib.umich.edu/p/passages/4761530.0005.012/ [besoek 2 Maart 2015]. 
Daar was nie één enkele sentrale artistieke beweging wat hierdie verskuiwings gekaraktiseer het nie, maar die feit dat hulle chronologies oorvleuel het is van belang. Pieter-Dirk Uys het sy naam gevestig met die satiriese karakter, Evita Bezuidenhout, en sy/haar eenpersoon teaterstukke wat gespot het met die NP. Dis opmerklik dat Uys se stukke nooit gesensor is nie, hoewel baie van die inhoud teen die wet was. Dit was eers met die uitreiking van video-opnames wat dit 'n 2-21 ouderdomsbeperking gekry het. ${ }^{72}$ Teater het een van die weinig uitdrukkingsmoontlikhede gebied aan Afrikaanse protesstemme:

Indeed, ... the theatre became one of the last voices permitted to speak after the media and other avenues of protest had effectively been silenced ... Why the theatre was allowed to continue, when other voices of protest were banned, imprisoned, murdered, exiled and tortured is a question frequently debated. A popular explanation - perhaps the most convincing - is that the government used theatre, and Black theatre in particular, as evidence for their argument before world opinion that conditions within South Africa were not truly repressive. But while the Market Theatre and other groups were permitted to mount productions of radical protest and even to tour abroad, plays that threatened to gather popular support in the townships were severely restricted and quickly silenced. ${ }^{73}$

Die Markteater is veral opmerklik: 'n plek waar die eerste "live” Musiek-en-Liriek konsert in 1979 gehou is, maar in 1981 ook Hennie Aucamp se politieke kabaret Met Permissie Gesê en 'n aantal ander soos Die van Aardes van Grootoor, met Pieter-Dirk Uys. ${ }^{74}$ Dit was baie gewild onder middelklas Afrikaners. Hoewel Musiek-en-Liriek nooit so openlik polities soos die radikale Voëlvry-beweging van die laat 1980's was nie, het albei - op verskillende tye en maniere - geresoneer met groter foutlyne in die magsbasis van Afrikaner politiek. William Beinart het uitgewys dat Afrikaner etniese identiteit teen die 1970's geërodeer is deur kulturele sekularisme wat waarskynlik vererger is deur die koms van televisie. ${ }^{75}$ Koos Kombuis herinner ons aan die belang van konteks wanneer'n mens die veranderende Afrikaner kulturele landskap van die laat 1970's en 1980's probeer verstaan:

Ja, om reg te laat geskied aan al die klein literêre strominge van daardie tyd sal ek die hele kulturele landskap in Suid-Afrika van die vroeë jare tagtig in breër terme moet beskryf.Want die dinge wat met ons gebeur het. en wat deur ons laat gebeur is, moet gesien word teen 'n backdrop van parallelle strominge in populêre musiek, ondergrondse politiek en protes teater. ${ }^{76}$

Ondanks die dekades van konserwatisme, isolasie, bangmakery en sensuur wat deur Afrikanernasionalisme geëis en veroorsaak is, het sommige Afrikaanse kunstenaars die intellektuele uittog uit die Laager onderneem. Afrikaanse literatuur, musiek en teater het die veranderende sosio-politieke toestande in Suid-Afrika weerspieël. Dit het die status quo bevraagteken, weerstand gebied teen die konserwatisme van 'n Calvinistiese samelewing, en die Afrikaners wat dié skuif gemaak het se gevoelens van vervreemding beliggaam. Om terug te

72 P. Uys, Between the Devil and the Deep: a memoir of acting and reacting (Kaapstad: Zebra, 2005), p. 89.

73 Opperman, “Revolution and conscience: South African theater, June 1976 to February 1990", pp. 14-16.

74 Uys, Between the Devil and the Deep, p. 88.

75 W. Beinart, Twentieth Century South Africa (Oxford: Oxford University Press, 2000), p. 187.

76 Kombuis, Seks \& Drugs \& Boeremusiek, p. 163. 
keer na die vraag of Musiek-en-Liriek 'n beweging was - die koherensie daarvan is waarskynlik deur joernaliste oordryf en die politieke impak daarvan was gering. Dit was nie ondergronds nie (dit was miskien nie nodig nie), was meesal nie ondermynend nie, maar het nietemin 'n mate van verandering beteken in die verbeterde kwaliteit van Afrikaanse musiek- hoe subjektief dit ook mag klink. 'n Mens moet ook eerlik wees en vra of dit hoegenaamd nodig is om dit as 'n beweging te beskou - of dit 'n ware beweging was of nie doen niks om die ontsag waarmee die musiek van die era vandag bejeen word, te skaad nie. Daar was in die vroeë 1980's ook ander noemenswaardige dinge in populêre Afrikaanse musiek aan die gang wat niks met Musiek-en-Liriek te make gehad het nie.

\section{Die Grensoorlog as agtergrond vir ondermynende Afrikaans rock}

\section{Since the beginning of the 1980s, growing numbers of Afrikaner national servicemen began to ask: "What are we fighting for?"77}

Die sosiale impak van Suid-Afrika se betrokkenheid by die Grensoorlog op die grens tussen Namibië en Angola gedurende die 1970's en 1980's het in die laaste jare hernieude aandag getrek. ${ }^{78}$ Onder Botha is die rol van die weermag tussen 1978 en 1983 uitgebrei. ${ }^{79}$ Hierdie militarisering van die wit Suid-Afrikaanse samelewing en die konstruksie van wit gemilitariseerde manlike identiteite was sterk gemeenskapskragte, maar het toenemend ongewild geraak en 'n mate van weerstand in Suid-Afrika se wit bevolking opgeroep. Dié weerstand was 'n teken van wyer politieke meningsverskille en verset teen apartheid. Drewett het versinnebeeldings van hierdie spanning in populêre kultuur ondersoek deur te kyk na die verhoudings tussen populêre musiek (meesal

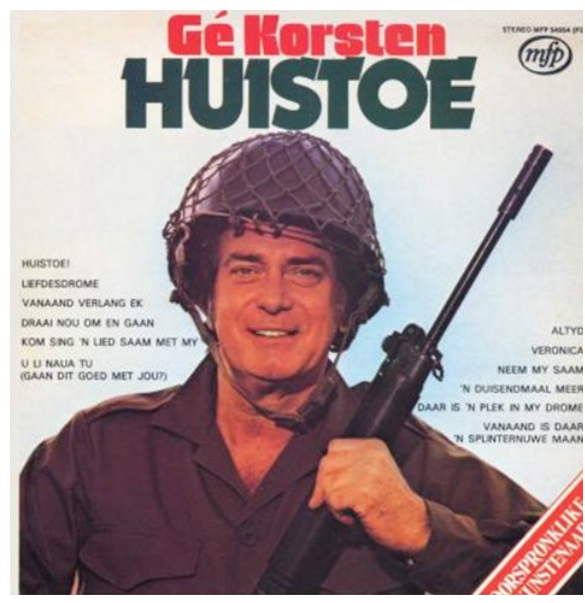

Ter ondersteuning van die Grensoorlog: Gé Korsten se Huistoe, 1979 (MFP 54954) Engels) en verset, asook die rol van musikante as "intellektuele van die beweging" binne wyer kringe van politieke protes ${ }^{80}$ Engelse groepe soos Bright Blue, die Kalahari Surfers en die Cherry Faced Lurchers, saam met solokunstenaars soos Roger Lucey was openlik gekant teen apartheid en diensplig vir wit mans in gewapende konflikte, en het dikwels opgetree onder die vaandels van die End Conscription Campaign (ECC). Hierdie optredes was hoogs gepolitiseerd en het 'n groot risiko vir die kunstenaars ingehou. Veral Roger Lucey se uitgesprokenheid het hom onder die aandag van die veiligheidspolisie gebring,

77 Hopkins, Voëlvry, p. 59.

78 M. Drewett, "Battling over Borders: Narratives of Resistance to the South African Border War Voiced through Popular Music”, Social Dynamics: A Journal of African Studies, 2003, 29: 1, pp. 78-98; sien ook M. Drewett, "The Construction and Subversion of Gender Stereotypes in Popular Cultural Representations of the Border War", in G. Baines and Peter Vale (reds.), Beyond the Border War: New Perspectives on South Africa's Late Cold War Conflicts (Pretoria: Unisa Press, 2008), pp. 94-119.

79 Beinart, Twentieth Century South Africa, p. 263.

80 Drewett, “Battling over Borders", pp. 78-98. 
wat 'n beampte, Paul Erasmus, aangestel het met die opdrag om sy loopbaan te verwoes. ${ }^{81}$

In teenstelling hiermee was populêre kultuur wat die oorlog gesteun het (musiek, film en literatuur as propaganda) natuurlik ook algemeen. Verskeie Engelse en Afrikaanse musieksnitte het op die mark begin verskyn. Onder die Afrikaanse uitreikings was twee plate van die gewildste en besverkopende Suid-Afrikaanse sangers van alle tye, Gé Korsten se Huistoe en Bles Bridges se Onbekende Weermagman. Dis opmerklik dat terwyl party Engelse groepe openlik gekant was teen die weermag, die oorlog en apartheid, Afrikaanse musiek meesal amper heeltemal inskiklik gebly het. Protes onder Afrikaners was nog skaars, hoewel daar 'n paar uitsonderings was.

In 1983 het twee kunstenaars Afrikaanse liedjies uitgereik met parodieë op die weermagervaring in 'n tyd toe verset teen diensplig en Suid-Afrika se betrokkenheid in die Grensoorlog voortdurend toegeneem het. Bernoldus Niemand (die alternatiewe persona van die Engelssprekende musikant James Phillips) het sy enkelsnit "Hou my vas Korporaal" uitgereik, en die rock-groep Wildebeest het 'n EP, Horings op die Stoep, uitgebring met die liedjie "Bossies". "Bossies" is 'n spreektaalterm vir die post-traumatiese stres waartoe gevegte in die grensoorlog dikwels gelei het. Die feit dat dit Afrikáánse liedjies was, is aangrypende uitbeelding

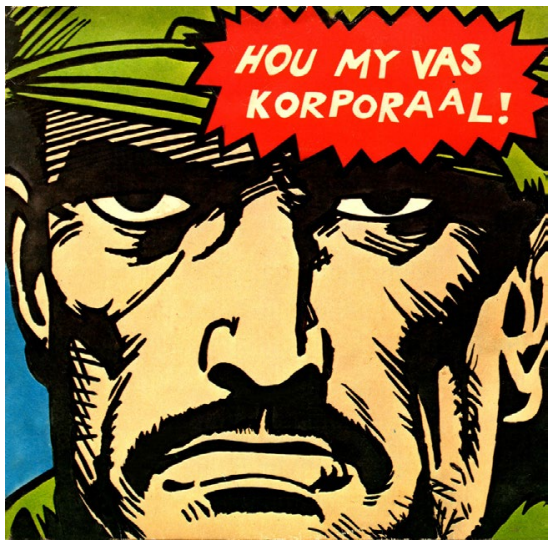

Bernoldus Niemand se 1983 enkelsnit "Hou my vas Korporaal" (Shifty Music OU | |6-A))

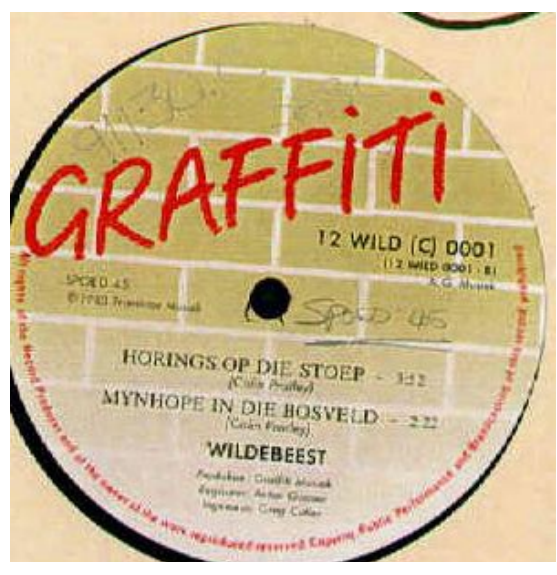

Wildebeest se 1983 EP Horings op die Stoep ( 12 Wild (C) D 00I). van die ontrafeling van Afrikaner hegemonie. Dit was 'n belangrike verandering, aangesien Afrikaners as 'n groep stellig meer in die apartheidstelsel belê het as hulle wit Engelse eweknieë, omdat die Afrikaner-samelewing en kultuur meer direkte bande gehad het met (en verantwoordelik was vir) die nasionalistiese ideologie wat dit in stand gehou het.

Al was hulle nie kommersiële suksesse nie, was "Hou my vas Korporaal” en "Bossies" die vroegste voorbeelde van Afrikaanse musiek wat die meningsverskille weerspieël het van 'n groot groep troepe wat die gewapende konflik waar hulle ingesleep is, bevraagteken het. Hulle beklemtoon ook nog 'n belangrike tema: die onderskeid in die reaksies tussen "hoë" en "lae" (of "populêre") kuns. Die postmoderne dekonstruksie van die Afrikanersamelewing in Afrikaanse literêre werke en kabarette verteenwoordig 'n diskoers wat in gevestigde kritiese kunskringe tuisgehoort het, terwyl bands heeltemal onbekragtig en ontoerekeningsvatbaar was. Groepe soos Wildebeest en kunstenaars soos Bernoldus Niemand (en sonder twyfel ook talle ander minder bekende groepe)

81 Drewett, "Stop this filth", p. 25. 
het 'n nie-kommersiële subkategorie verteenwoordig met min tot geen blootstelling in die hoofstroom. Dit was heel anders as Musiek-en-Liriek, wat die steun van die hoofstroom televisie gehad het, en teater en kabarette wat in opdrag gewerk het van, en befonds is, deur provinsiale uitvoerende kunste organisasies wat deur die staat goedgekeur is. ${ }^{82}$ Die twee wêrelde het soms oorvleuel - Koos Kombuis was 'n leierfiguur by die Tagtigers en het literêre werke gepubliseer voordat hy as 'n liedjieskrywer-musikant bekend

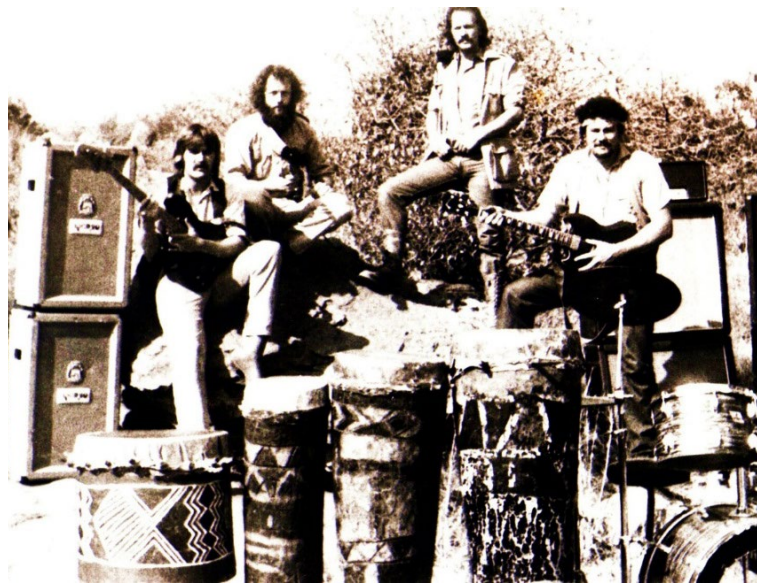

Wildebeest in die vroeël980's. geraak het - maar verdere skakels tussen die literêre- en musiekbewegings van die 1980's bly indirek, en hang dikwels af van iets so eenvoudigs as wat Shaun de Waal "toonaard" noem:

Many considered Bernoldus Niemand's album, Wie is Bernoldus Niemand? to have started the "Afrikaans new wave" which has climaxed in the Voëlvry tour. It was the first record of its kind, and it set the tone: observant, satirical (sometimes gently so, sometimes more bitingly), and couched in the rebellious language of rock ' $n$ roll. ${ }^{83}$

"Hou my vas Korporaal" is in Februarie 1985 gevolg deur die album Wie is Bernoldus Niemand?, weereens deur die progressiewe platemaatskappy Shifty. ${ }^{84}$ Hoewel dit nie James Phillips se eerste opnames was nie, was "Hou my vas Korporaal" sy eerste in Afrikaans. Die plaat is as 'n projek vir sy B.Mus-graad aan Universiteit van Witwatersrand ingedien, maar nie aanvaar nie. Soos te verwagte, is dit deur die SAUK verbied.$^{85}$ Die duidelike satire op die weermagervaring - waarmee soveel jong wit Suid-Afrikaanse mans kon assosieer - sou 'n gereelde tema word vir die latere Voëlvry kunstenaars. "Hou my vas Korporaal" het na die stigting van die ECC, in 1984, die nie-amptelike temalied van die beweging geword. ${ }^{86}$

Voor Bernoldus NiemandhetJames Phillipsin'nEngelsegroepmet dienaam CorporalPunishment gespeel, wat uit sy tuisdorp Springs gekom het, 'n myndorp aan die Oos-Rand van Johannesburg en in die laat-1970's 'n broeines vir 'n punk-tipe anti-establishment musiek. ${ }^{87}$ Met Phillips en Carl Raubenheimer as die hoof-liedjieskrywers het Corporal Punishment bytende politieke en sosiale kommentaar gelewer. Hoewel hulle stilisties beïnvloed is deur Britse Punk in die 1970's, kon punk-groepe in Suid-Afrika nie realisties aanspraak maak op dieselfde konneksies met die werkersklas soos byvoorbeeld die Sex Pistols nie, want in die algemene plaaslike konteks het hulle ras hulle bevoorreg gemaak. Nie alle wittes was egter ewe bevoorreg nie, en James Phillips het die

82 Soos Kruik and Truk.

83 S. de Waal, "Rocking rebels discover R'n R", The Weekly Mail, 26 Mei - 1 Junie 1989, p. 30.

84 http://rock.co.za/files/jp_niemand.html [besoek 21 Junie 2013].

85 Ibid.

86 http://mhambi.com/2010/02/ninja-is-the-new-james-phillips/ [besoek 13 Augustus 2013].

87 Hopkins, Voëlvry, pp. 91-92. 
eienskappe van die wit werkersklas in sy liedjies (en in die karakter van Bernoldus Niemand) ingeskryf, wat hy ongetwyfeld in Springs waargeneem het. Die Oos-Rand het 'n interessante geskiedenis van werkersklas Afrikaanse musiek uit 'n ander era. Die musiek van David de Lange (wat in Benoni, nie ver van Springs af, gewoon het) is 'n goeie voorbeeld. Baie ander boereorkeste wat vroeg in die 1930's plate opgeneem het was ook van die Oos-Rand af. Terwyl die musiek van die ander Voëlvry kunstenaars, Koos Kombuis en Johannes Kerkorrel, later gespot het met die smaakloosheid van middelklas Afrikaner suburbia vanuit die posisie van rebelse middelklas Afrikaners, het die tema van die wit werkersklas in James Phillips se musiek, veral in sy Afrikaanse werk as Bernoldus Niemand, 'n ander soort ondermyning verteenwoordig. In die 1980's was werkersklas Afrikaners geneig om die politiek regse Konserwatiewe Party van Andries Treurnicht, wat in 1982 weggebreek het, te ondersteun. Phillips het nie wat taal, kultuur of politiek betref aan hierdie klassegroep behoort nie. Hy het later die Cherry Faced Lurchers gevorm wat, soos reeds genoem, dikwels by politieke byeenkomste van die ECC opgetree het en baie polities uitgesproke musiek opgevoer het. Een van hulle liedjies, "Shot down in the Streets", is ingesluit in Shifty se 1985 versamel-album met die naam Forces Favourites wat vrygestel is in samewerking met die ECC.

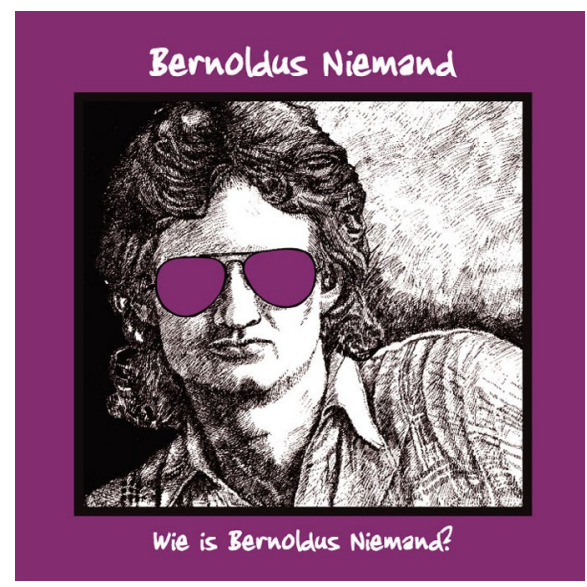

Die debuutalbum van James Phillips se alter-ego, Bernoldus Niemand, 1985 (Shifty 003).

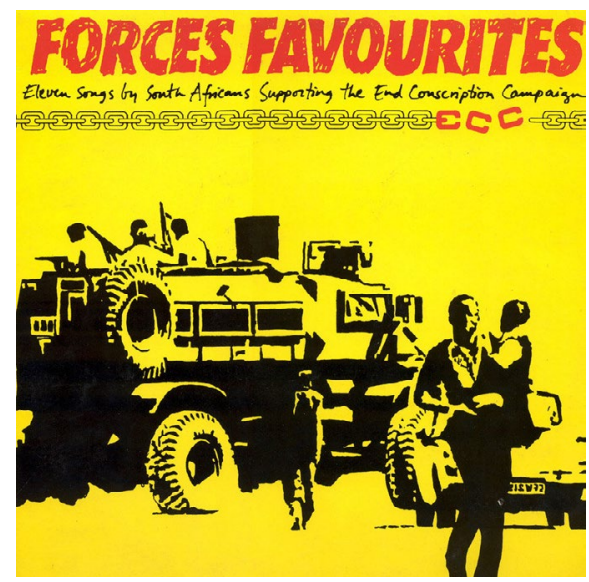

Shifty Records se Forces Favourites, ter ondersteuning van die ECC, 1985 (SHIFT I0).

Hoewel Niemand se invloed op Voëlvry omstrede was (soos wat Hopkins voorstel) ${ }^{88}$ en skynbaar ook nie sy hoogtepunt as kunstenaar was nie, bly dit 'n roerende kommentaar oor wit diensplig tydens apartheid. Dis opmerklik dat Phillips die Bernoldus Niemand-persona vir die Voëlvry-toer teruggebring het en liedjies uit Niemand se repertoire opgevoer het, en selde of ooit materiaal uit sy Corporal Punishment en Cherry Faced Lurchers dae. ${ }^{89}$

Wildebeest was aan die ander kant op hulle eie manier 'n enigmatiese groep. Byvoorbeeld was die baskitaarspeler, Piet Botha, die seun van die Minister van Buitelandse Sake, Pik Botha. ${ }^{90}$ Hulle het in 1981 op die televisieprogram Kraaines verskyn, in militêre-styl kakieklere, en het op

88 Ibid., p. 91.

89 Elektroniese kommunikasie met "Dagga" Dirk Uys, organiseerder van die Voëlvry-toer, 14 Maart 2014.

90 He became one of the most recognised Afrikaans songwriters of the last 30 years. 
tradisionele Afrika-dromme gespeel en swaar Afrikaanse rock-liedjies opgevoer. ${ }^{91}$ Die liedjies is almal deur die tromspeler Colin Pratley gekomponeer, wat net soos James Phillips nie 'n moedertaal Afrikaanssprekende was nie. Wildebeest is deur Afrika-genres en rock-musiek beïnvloed, en het 'n verskeidenheid inheemse instrumente gebruik en soms in Afrikaans gesing. Hulle eerste live album, Wildebeest Bushrock One, was die Rand Daily Mail se album van die jaar, en het min Afrikaanse materiaal bevat. ${ }^{92}$ Hulle het ook koppe gestamp met die establishment toe 'n kerk in Potchefstroom hulle wou keer om daar op te tree. ${ }^{93}$ In 1983 het hulle 'n EP, Horings op die Stoep, opgeneem met Anton Goosen as vervaardiger. Dit het vier snitte bevat en dis beduidend dat hulle almal in Afrikaans was (hoewel "Hotnotsgot" tegnies gesproke 'n instrumentele snit is). Dit was hulle laaste keer in die ateljee. Anders as Phillips was Wildebeest nooit betrokke by die formele verset teen diensplig nie, en hulle het nie bande gesmee met liberale linkse politieke bewegings nie.

In die lig van die sosio-politieke atmosfeer van die vroeë 1980's was liedjies soos "Hou my vas Korporaal" en "Bossies" belangrik. Albei liedjies het gevoelige en realistiese aspekte aangeroer van 'n ervaring wat baie wit Suid-Afrikaanse mans sedert 1967 gedeel het: verpligte militêre diens. Dit het in skril kontras gestaan met die talle musikale produksies wat militêre diens ondersteun het of diensplig uitgebeeld het as die patriotiese plig van jong wit Suid-Afrikaanse mans. In 'n wyer konteks het die idees in Niemand en Wildebeest se liedjies verband gehou met 'n groeiende korpus grensliteratuur wat die monolitiese Afrikaner identiteit-stereotipes wat deur die weermag opgebou is, afgebreek het. So 'n anti-leierskap kultuur vanuit die Afrikaner-samelewing was 'n besonder taai kwessie. Dit het ook geresoneer met die wyer foutlyne in die Afrikaner-samelewing soos wat die apartheid regime se mag begin taan het. Die spesifieke belang van "Hou my vas Korporaal" en "Bossies" is dat hulle alternatiewe interpretasies van die weermagervaring gebied het, en in die verlenging daarvan, het die wit Afrikaner manlike identiteit, 'n veel wyer sosio-politieke verskuiwing, weerklank.

\section{Reaksie van die staat en sensuurraad}

Soos voorheen genoem, het die oprigting van die Publikasieraad in 1974 'n nuwe dimensie van sensuur ingelui. ${ }^{94}$ Op die kulturele front het dit 'n meer gesofistikeerde toepassing van sensuur beteken. Jansen van Rensburg se studie oor sensuur by die SAUK van 1976-1996 fokus op foto's van ongesorteerde dokumente, wat haar toelaat om 'n grafiek saam te stel van liedjies wat vir uitsaaidoeleindes by alle radiostasies van die SAUK ingedien is, en hoeveel daarvan as ongeskik vir uitsending beskou is. ${ }^{95}$ Haar studie is belangrik omdat dit, onder andere, kwantifiseerbare

91 https://www.youtube.com/watch?v=42wjjQmKC6Q\&hd=1 [besoek 24 Januarie 2014].

92 Onderhoud met Piet Botha, 05 Mei 2014.

93 Ibid.

94 Vir 'n meer gedetailleerde analise van die struktuur van staatsensuur tydens apartheid is Drewett se werk gesaghebbend, so ook Merrett s'n. Sien M. Drewett, "An analysis of the censorship of popular music within the context of cultural struggle in South Africa during the 1980s", ongepubliseerde D.Phil Tesis, Rhodes Universiteit, 2004); sien ook C. Jansen van Rensburg, "Institutional Manifestations of Music Censorship and Surveillance in Apartheid South Africa with Specific Reference to the SABC from 1974 to 1996", ongepubliseerde MMus dissertasie, Universiteit Stellenbosch, 2013, pp. 34-37; sien ook C. Merrett, A Culture of Censorship: Secrecy and Intellectual Repression in South Africa (Kaapstad, David Phillip Publishers, 1994).

95 Jansen van Rensburg, "Institutional Manifestations of Music Censorship and Surveillance in Apartheid South Africa”, p. 98. 
data verskaf. In die periode van 1986-1996 is in totaal 1619 liedjies by die SAUK ingedien vir uitsaaidoeleindes. Hiervan is 890 liedjies as ongeskik vir uitsending bevind. Dit beteken dat byna $55 \%$ van alle liedjies tydens dié periode (wat, toegegee, slegs 'n laat stadium van apartheidsensuur en die eerste paar jaar van demokrasie verteenwoordig, maar nietemin 'n baan voorstel wat baie lank voor dit begin is) van die lug af gehou is. Hierdie syfers verwys na alle soorte musiek wat ingedien is, nie net Afrikaanse liedjies nie, en dit is onduidelik of dit werk van internasionale kunstenaars insluit.

Die komplekse stel veiligheidsmaatreëls, insluitend sensuurwette, het tot baie verwarring en onsekerheid by die sensuurraad self gelei, en ook by die kunstenaars wie se werk gesensor is. Dit het in 'n soort kat-en-muisspeletjie gemanifesteer met die irrasionele implementasie van die wette wat veelvuldige ammunisie aan anti-establishment Afrikaners verskaf het. In 'n bespreking van sensuur by die eerste Freemuse-wêreldkonferensie oor musiek en sensuur in Kopenhagen in November 1998, het Cecile Pracher, 'n voormalige SAUK-sensor, die volgende aan die paneel vertel:

\begin{abstract}
At the time I was there between the 1980s and 1990s. It was the time of P.W. Botha and Apartheid was in full swing and the state of emergency was declared and everything became tighter and tighter. Things that would have been allowed five years earlier were frowned upon so therefore it was a very unnatural society to live in ... Records weren't banned by the SABC as a record with all the cuts. It was normally one, two or three cuts but sometimes it was eight, nine or ten. But mostly it was about three or four cuts and we had to put on stickers onto the LP's and in fact some of the LP's were scratched so that those cuts weren't played. With CD's of course that opportunity was lost. ${ }^{96}$
\end{abstract}

Pracher se storie bevestig in 'n mate dat die sensuurraad in sekere periodes meer gevoelig was, soos Ingrid Byerly ook uitgewys het. ${ }^{97}$ Vir Anton Goosen was die invloed van die SAUK-sensuurraad op die komposisie van sy vroeë liedjies baie belangrik. Hy het op sensuur gereageer deur opsetlik die sensuurraad die harnas in te jaag, wat nie net hulle magsposisie ondermyn het nie maar hulle ook in die openbaar verkleineer het. Dis te betwyfel of dit 'n dekade vroeër moontlik sou gewees het. Goosen verduidelik:

Dis psigologiese ding wat hier plaasvind is jy begin hierdie stryd voer teen die senssuurraad. Die SAUK se sensuurraad. Wat nie gesond is nie. Jy moet tog skryf oor wat binne-in jou is ... Jy weet jy gaan verbied word, so ok, die eerste ding wat ons doen is ons vat hom nie radio toe nie, die eerste ding wat ons doen is ons bel Rapport en ons maak 'n voorbladstorie van dit. Soos "Boude", of "Gatvol".98

Boet Pretorius, die eienaar van Decibel-platemaatskappy, het ook verwys na hierdie soort stryd tussen die kunstenaar en die SAUK se sensuurraad In sy geval het hulle die Sondagkoerant Rapport - wie se joernaliste "die SAUK gehaat het" 99 - betrek toe hulle ingelig is dat 'n

96 Drewett, "Stop this filth", pp. 53-70.

97 I. Byerly, "Mirror, Mediator, and Prophet: The Music Indaba of Late-Apartheid South Africa", Ethnomusicology, 42:1 (1998), p. 14.

98 Onderhoud met outeur, Gansbaai, 29 April 2013.

99

Telefoniese onderhoud met outeur, 22 Julie 2013. 
plaat van een van sy topkunstenaars, die komediant Leon Schuster, verbied sou word. Die koerantopskrif het blykbaar gehelp met die verkope van die plaat. ${ }^{100}$ Een memo wys dat stoeier/ vermaaklikheidskunstenaar Mike Schutte se liedjie "Moeilike Mike", ook by Decibel uitgereik, ongeskik vir gebruik "in enige program van die SAUK se uitsaaidienste" was. ${ }^{101}$ Vreemd genoeg is selfs operastukke soms verbied, soos toe een kant van die wêreldberoemde operasanger, Maria Callas, se opname van Lucia Di Lammermoor, in Italiaans, uitgekrap is. ${ }^{102}$

Coenie de Villiers is nog 'n kunstenaar wat met die Musiek-en-Liriek beweging geaffilieer is. Hy is beïnvloed deur die musiek op Radio Bantu, die SAUK se swart radiodiens wat opsetlik die programsamestelling tussen verskillende etniese groepe verdeel het. Hierdie invloed is nog 'n voorbeeld van hoe musiek in staat was om die strengbewaakte rassegrense tydens apartheid te oorbrug. De Villiers onthou:

Ek was van kindsbeen af aangegryp deur die klanke wat ander etniese en kultuurgroepe geskep het en het grootgeword met die klanke van die eertydse Radio Bantoe (!) in die kombuis. Dit was dus vir my 'n baie natuurlike proses waaroor ek nie nagedink het nie. Ek het die eerste keer besef dat dit problematies mag wees toe ek saam met die Abasandizi Sangers in die Kaap wou musiek maak, en hulle katvoet moes verskoning maak dat ons 'liewer maar by die huis' moes musiek maak - dit sou problematies wees in die openbaar. Daarna het ek heelwat musiek gemaak saam met die wonderlike jazzkunstenaars van die Kaapse Vlakte, maar dit is nie altyd goed ontvang deur die destydse bedeling nie. My eerste albums is ook met 'n speelverbod opgesaal omdat die SAUK van toentertyd dit as 'ongewens' beskou het. ${ }^{103}$

Cora Marie was 'n hoofstroom popsanger wat ook gospelliedjies gesing het. Haar lied "Ster van Bethlehem", deur Anton Goosen geskryf, is vir 'n skynbaar bizarre rede verbied, soos Marie se man, Corrie Myburgh, onthou:

Hulle het dit verban omdat hulle gesê het jy kan nie gospel op 'n beat nie... Vandag is dit belaglik, maar dit was hulle reël daardie tyd. Ek glo tot vandag nog die SAUK het die groei van Afrikaans getemper omdat daar so baie reëls en regulasies was. Dit was eers ná 1994 dat die taal, veral wat musiek aanbetref, weer begin groei het. ${ }^{104}$

Al hierdie voorbeelde ondermyn die idee dat net politieke musiek verbied is. Baie mense deel Myburgh se mening oor die SAUK wat Afrikaanse musiek geskaad het met hulle beperkend maatreëls.

Die konserwatiewe Afrikaner-samelewing het ook ander soorte druk uitgeoefen. In 'n opmerklike daad van politieke verset het Amanda Strydom, wat ook deel was van die Met Permissie Gesê

\section{Ibid.}

101 SAUK interne memo, 28 November 1986, aangehaal in Jansen van Rensburg, "Institutional Manifestations of Music Censorship and Surveillance in Apartheid South Africa”, p. 75.

$102 \mathrm{http}: / /$ soulsafari.wordpress.com/tag/music-and-censorship-during-apartheid-in-south-africa/ [besoek 22 Augustus 2013.

103 Roggeband, 50 Stemme, p. 52.

104 Corrie Myburgh in Roggeband, 50 Stemme, p. 56. 
rolverdeling, in 1986 by 'n optrede in die Oude Libertas-teater in Stellenbosch (dieselfde teater waar Musiek-en-Liriek-konserte vroeër opgevoer is) die swartmag saluut gegee en "Amandla" ("mag" in isiXhosa en isiZulu,' n gewilde kreet in die anti-apartheidstryd) geroep. Dit was nadat sy haar eie komposisie, "Die pas" gesing het, wat uit protes teen die Paswette geskryf is. Sy is swaar deur die Afrikaanse media gekritiseer as onpatrioties en 'n klad op die naam van die Afrikaner. ${ }^{105}$ Strydom onthou:

Die voorval het my lewe verander. Aanvanklik was die nagevolge ontsettend traumaties - om in die tagtigs, in die destydse konserwatiewe Stellenbosch tydens die apartheidsjare op te staan en my lied oor die paswette te sing, was so goed as om 'n doodsvonnis oor myself uit te spreek. Maar dit was my sielsoortuiging. ${ }^{106}$

Die gebaar het teen 'n prys gekom. Ná die negatiewe reaksies van die Afrikaner gemeenskap het Strydom 'n ineenstorting gehad en is gediagnoseer met bipolêre depressie. Sy het eers in die vroeë 1990's na die verhoog teruggekeer. ${ }^{107}$ Anton Goosen het ook oor ander intimidasiestrategieë gepraat:

Die oomblik as jy buite dit beweeg het, soos Roger Lucy, het hulle begin om jou telefoonlyn te tap. En hierdie het voortgeduur... Houtstok was in 1990. Selfs daar was my foon afgeluister. As ek met my girlfriend praat kan ek hierdie mense hoor in en uit chip. Daar was mense met guns by die kerkplein met ons show. ${ }^{108}$

Dit was baie moeilik om plate te sny as hulle inhoud ongewens was, soos wat Lloyd Ross van Shifty Records verduidelik:

These albums introduced us to another form of creative strangulation in the person of Pietman, a cutting engineer at EMI's record plant. At that, EMI had the only cutting lathe in southern Africa, so you either dealt with EMI and Pietman or didn't make records at all. Pietman got through the first side of Happy Ships without mishap, but halfway through the second he heard the word "fuck" and stopped the lathe. The Kalahari Surfers album Own Affairs didn't even make it past the second song! It is difficult to believe this now, but in 1984, a technician essentailly had the power to decide what got released on vinyl in pretty much al of southern Africa. ${ }^{109}$

Nog 'n faktor om in gedagte te hou is dat baie min kunstenaars genoeg uit musiek - of ander kunsvoms - verdien het om dit voltyds te beoefen, wat die pragmatiese benadering verklaar wat kunstenaars moes volg om in die bekrompe Afrikaanse musiekmark te oorleef. Pracher gee perspektief oor hoe kunstenaars hierdie komplekse sisteme moes bestuur om kop bo water te hou:

The effect of the SABC clamping down on information was directly resulting in the record companies taking a particular stance. They were in it for business, that's very clear, and they were protecting their rights. They knew that most often if a song is

105 Roggeband, 50 Stemme, pp. 9-10.

106 Ibid., p. 10.

107 Ibid.; sien ook G. Edwards: “Amanda op die Kruin”, Die Huisgenoot Tempo 3, 2012, p. 48.

108 Anton Goosen, Onderhoud met outeur, Gansbaai, 29 April 2013.

109 http://shifty.co.za/the-shifty-story/ [besoek 3 April 2017]. 
not given air time it doesn't have the same chance of being popular as the next one. So they forced a kind of censorship on their artists. I think what happened then was that the artists had their won censorship forced on themselves for bread and butter. If you rely on your income then you very often take the easier road. That had a major effect on SA's music in the 1980's and the 1970's. If censorship wasn't so completely successful, there would sooner have been a reaction from the people. That goes for music, but also much wider. ${ }^{110}$

Die kunstenaars wat met Musiek-en-Liriek beroemd geword het moes vindingryke maniere kry om suksesvol te bly. Laurika Rauch het reeds voor die begin van Musiek-en-Liriek in kabarette opgetree en na die aanvanklike suksesse van haar eerste drie albums, het sy voorgegaan daarmee deur 'n aantal van Jacques Brel se kabarette op te voer. Goosen het talle treffers vir ander, meer hoofstroomsangers soos Sonja Herholdt ${ }^{111}$ en Carike Keuzenkamp ${ }^{112}$ geskryf. David Kramer is met die Volkswagen Kombi geassosieer deur 'n reeks beroemde televisie-advertensies van 1984-1996 - die langste onderskrywing van 'n produk deur 'n beroemde in die geskiedenis van die Suid-Afrikaanse reklamewese. ${ }^{113}$ Hierdie openbare persona, wat onder Afrikaners so gewild was, was vir Kramer dikwels 'n bron van ongemak. ${ }^{114} \mathrm{Hy}$ was koersvas as een van die mees prominente wit Afrikaanse musikante om die gemene musikale erfenis van wit en bruin Afrikaanssprekers te ondersoek, en het daarmee die konstruksies van wit ras-oorheersing in populêre Afrikaanse musiek ondermyn. Sy werk het baie meer polities van aard geword met die uitreiking in 1986 van sy album Baboondogs, en hy het met die bruin musikant Taliep Petersen saamgespan vir Distrik Ses - Die Musiekblyspel, die begin van 'n lang en vrugbare samewerking wat met Petersen se moord in 2006 tot' $n$ tragiese einde sou kom. ${ }^{115}$ Vier liedjies van die klankbaan is deur die SAUK verban, ${ }^{116}$ en die blyspel het beperkte toegang gehad tot teaters wat deur die staat beheer is, waar produksies met 'nie-blanke' rolbesettings en skrywers verbied is. ${ }^{117}$ Van al die kunstenaars wat bande met Musiek-en-Liriek gehad het, was Anton Goosen, David Kramer en Amanda Strydom waarskynlik polities die mees uitgesproke. Dit is egter sinloos om te soek na Voëlvry-agtige radikalisme onder die Afrikaanse kunstenaars van die laat 1970's en vroeë 1980's. Musiek-en-Liriek was minder samehangend en meer divers, en het 'n veel groter publiek aangespreek. En die treffendste, as jy in dié era na Musiek-en-Liriek kunstenaars geluister het, was jy nie noodwendig liberaal of ontevrede met apartheid of die NP nie.

110 C. Pracher, "The Censored meet their Censor - Music and Censorship during Apartheid in South Africa", beskikbaar by http://freemuse.org/archives/5671 [besoek 8 Mei 2012].

111 Roggeband, 50 Stemme, p. 231.

112 Ibid., p. 44.

113 Slabbert en De Villiers, David Kramer, p. 180.

114 Ibid., p. 196.

115 Ibid., p. 11, p. 277.

116 SAUK Memo no. 209, 28 November 1986, C. Jansen van Rensburg, "Institutional Manifestations of Music Censorship and Surveillance in Apartheid South Africa with Specific Reference to the SABC from 1974 to 1996 " MMus Tesis, Universiteit Stellenbosch, 2013, p. 75.

117 Slabbert en De Villiers, David Kramer, p. 229. 


\section{HOOFSTUK SES}

\section{Alternatiewe Afrikaanse musiek teen die einde van apartheid}

\section{'n Outobiografie}

Ek is in 1975 in Uitenhage gebore. Ons het aan die rand van 'n tipiese wit middelklas buurt gewoon. Voor ons huis was daar 'n oop veld en 'n heuweltjie, en agter die heuweltjie was Langa, wat "Sonop" in isiXhosa beteken. Langa was naby genoeg dat ek die vurige politieke toesprake - en geweld - kon hoor. Dit het'n aanhoudende agtergrond geraas van my kinderdae geword. Dis nie die meer bekende township naby Kaapstad nie, maar op 21 Maart 1985 het die polisie 20 mense tydens 'n begrafnis progressie hier in ons Langa doodgeskiet. Dit was net meer as 'n kilometer van ons huis af. Een van die vroegste gedokumenteerde gevalle van 'n halssnoermoord' ${ }^{1}$ het twee dae later gebeur met die dood van Benjamin Kikini. Volgens die geskiedenisboeke is Enoch Sontonga, die Xhosa-sendeling wat in 1897 Nkosi Sikelel' iAfrika geskryf het, in ongeveer 1873 in Uitenhage gebore en hoewel die presiese plek nie bekend is nie, was dit waarskynlik naby aan waar ek grootgeword het. Die hospitaal waar ek gebore is, is net om die draai van ons huis en omtrent $200 \mathrm{~m}$ straat-op. Soos in baie staatshospitale tydens apartheid was daar 'n afdeling vir "Blankes" en een vir "Nie-Blankes". Al Langa se siek en beseerde inwoners moes deur die veld en verby ons huis loop tot by die hospitaal. Ek het dikwels bloedspore in die straat gesien, om die hoek en by die bult op tot by die

1 Die praktyk waarby iemand tereggestel word deur 'n motorband om sy nek te sit, dit met petrol te vul en aan die brand te steek. 
ingang vir 'Nie-Blankes' (aan die linkerkant) van die hospitaal. In die mid-1980's is ons straat aanhoudend deur Casspirs (gespanserde militêre voertuie) gepatrolleer. Op 'n stadium was daar vier skerpskutters op die dak van die hospitaal geplaas, sodat hulle die veld voor ons huis duidelik kon sien in geval enige van die township-geweld na die wit woonbuurte sou oorspoel. Soggens het die son agter die hospitaal opgekom, sodat hul skaduwees oor ons grasperk geval het.

Toevallig het die ligging van my ouers se huis dit vir my as jong kind onmoontlik gemaak om onbewus te wees van die politieke realiteit in Suid-Afrika in die laaste jare van apartheid. Om aan die rand van wit suburbia groot te word en na buite te kyk het 'n groot deel van my vormingsjare verpolitiseer. Die "onluste" tydens die noodtoestand van die mid-1980's was nie onsigbaar nie. Op 'n dag in 1989 het 'n vriend vir my 'n bootleg-kasset gegee met liedjies van Voëlvry, asook Piekniek by Dingaan, op. Skielik het ek musiek gehoor wat direk verband hou met wat ek elke dag gesien. Die foutlyne wat hierdeur blootgelê is (en die streep wat in die sand getrek is) het ook gelyk na ons straat aan die rand van die dorp. Dit het 'n groot invloed op my as 'n dertienjarige gehad. Ek het al die lirieke geleer. Ek het ook Johannes Kerkorrel se liedjies op die klavier leer speel, en Koos Kombuis s'n op die kitaar (dit was makliker). Van toe af het ek en my vriende, danksy 'n mengsel van hormone en tienerrebellie, dikwels ons onderwysers in die klaskamer uitgedaag oor hulle onwrikbaar nasionalistiese politieke oortuigings (ons is aangemoedig deur 'n gerug wat die rondte gedoen het - hoewel dit nooit bevestig is nie - dat dit onwettig was om skoolseuns te slaan vanweë hulle politieke oortuigings). Op een of ander manier het 'n groep wit skoolseuns in die Oos-Kaap (op 'n baie basiese vlak) verpolitiseerd geraak deur die musiek van die Voëlvry-beweging. Ons het dit ook, net soos ander tieners regoor die wêreld, geniet om te spot met die konserwatisme van die samelewing waarin ons grootgeword het. In 'n sekere sin gee my persoonlike band met Voëlvry my dus simpatie met die aanspraak dat dit 'n monumentele, aard-verskuiwende kultureel-politieke beweging was. Ek is wel ook daarvan bewus dat die klein groepie vriende op skool wat van 1989 af na Voëlvry musiek geluister het, presies dit was: klein. 'n Paar jaar later, in 1992 of 1993, het Anton Goosen en sy Bushrock band - waarvan Piet Botha deel was - by ons skool kom optree. Dit was die eerste live groep wat ek ooit gesien het en dit was in Afrikaans, en fantasties. Vir my het Voëlvry egter die belangrikste gebly.

\section{Voëlvry}

Hy [Johannes Kerkorrel] is besig om Suid-Afrika te oorrompel met 'n shit-hot Afrikaanse rock-band, om hier te koes en daar te duck, maar orals pop hy uit met sy boodskap van protes, van ontevredenheid, van opstand teen die staus quo. Oral waar hy gaan, verlos hy mense van die demone van Calvinistiese skuldgevoelens en Nasionalistiese rassisme, hy maak hulle oop vir die wonderlike emosies, hy weet presies hoe om sy web van landwye muitery te spin, hy verkondig die waarheid hard en duidelik, hy verkondig die evangelie waarna die jeug smagtend op soek was tot nou toe. ${ }^{2}$

In April en Mei 1989 het drie alternatiewe Afrikaanse groepe - digter/sanger André Letoit (wat later sy naam na Koos Kombuis verander het), Bernoldus Niemand se Swart Gevaar en

2 K.A. Kombuis, Die tyd van die Kombi's (Kaapstad: Human \& Rousseau, 2009), p. 130. 
Johannes Kerkorrel se Gereformeerde Blues Band - deur Suid-Afrika getoer (en Namibië vir een vertoning besoek) om die Afrikaner jeug te bevry met Afrikaanse rock'n roll. Die naam daarvan was Voëlvry en dit was 'n bewuste aanslag op die fondamente van 'n konserwatiewe Afrikanersamelewing wat'n onseker toekoms tegemoet gegaan het in die laaste dae van apartheid.

Die toer het baie aandag getrek omdat dit so totaal anders was as enigiets al ooit voorheen gedoen in Afrikaanse musiek. Soos die voorafgaande hoofstukke toon, was daar slegs geringe vyandigheid teenoor die staat in die Afrikaanse musieksektor. Teen die einde van die voorlaaste dekade van die twintigste eeu was dit baie maklik vir hierdie alternatiewe Afrikaanse kunstenaars om die Afrikaner-samelewing te skok. Die verstikkende konserwatisme van die Kerk, die politiek van die Nasionale Party (NP) regering, en hulle musikale mededingers in die vorm van hoofstroom Afrikaanse kunstenaars (veral die sentimentele sniksanger Bles Bridges), was almal maklik identifiseerbaar as deel van 'n enkele vyand. Ook konserwatiewe familie-opvoeding het die skuld gekry:

We did not merely dislike our parents; we despised them, loathed them, we wanted to torture and hurt and discredit them utterly. We had come to that terrible place in a neglected child's life when he loses the final vestige of respect for abusive elders. ${ }^{3}$

In politieke terme was dit die vyfde jaar van P.W. Botha se noodtoestand, troepe is regdeur die land die townships ingestuur om die wydverspreide politieke opstande te onderdruk, internasionale druk teen apartheid het kritieke vlakke bereik en die ekonomie was in die moeilikheid. Teen Januarie 1989 het Botha 'n beroerte-aanval gehad en in Februarie het hy bedank as leier van die NP, maar in die maand daarna geweier om die party se verkiesing van F.W. de Klerk as die nuwe Staatspresident te erken. Hy het uiteindelik in Augustus bedank en F.W. de Klerk het op 20 September 1989 die leiesels oorgeneem. Teen hierdié tyd het byna die helfte van die wit Afrikaanssprekendes die NP verlaat. ${ }^{4}$ Die dienspligtermyn in die weermag is verminder na een jaar en die verdedigingsbegroting is gehalveer, 'n aanduiding van die regering se teësin om hulle militêr teen politieke verandering te verset. ${ }^{5}$ In 1990 het De Klerk die ANC en ander swart politieke organisasies hertoegeaat en Nelson Mandela vrygelaat, 'n belangrike gebeurtenis in Suid-Afrika se geskiedenis wat baie media-aandag gekry het. In dieselfde jaar is die etno-politike betekenis van die Afrikaner geraak deur die insluiting van 'nie-blankes' in die NP

Hoewel Voëlvry nooit deel van die hoofstroom geword het nie, is die hoeveelheid akademiese werk wat daaroor gedoen is 'n aanduiding van die belangrikheid van die beweging. Voëlvry is bestempel as die belangrikste voorbeeld van gepolitiseerde Afrikaanse musiek in die apartheidsera. As onderwerp het Voëlvry 'n aantreklike geleentheid gebied om allerlei kruispunte van veranderende Afrikaner-identiteite en politieke omwenteling te ondersoek in 'n tyd wat vir die meeste wit Afrikaners byna openbarend was. In teenstelling hiermee het die werk van ander Afrikaanse musiekkunstenaars wat hulle politieke identiteit op 'n meer subtiele wyse uitgedruk het, minder aandag gekry. Die minder ooglopende, meer stemmige benadering van

3 Koos Kombuis, nawoord in Hopkins, Voëlvry, p. 235.

4 H. Giliomee, Die Afrikaners: 'n Biografie (Kaapstad: Tafelberg, 2003), p. 580. Ibid., p. 597.

5 Ibid. 
Musiek-en-Liriek was oor die algemeen baie gewilder onder die breër Afrikaanse publiek, maar te sag vir dié wat direk by die Voëlvry-beweging betrokke was. In die woorde van Max du Preez:

We had a general fuck-you attitude, and didn't believe the 1980s was a time for subtlety and good manners. ${ }^{6}$

Daar is ander spore van kritiese, anti-leierskap musiekoptredes wat Voëlvry voorafgegaan het, soos David Kramer se gebruik van musiek om rassehiërargië te ondermyn, "Hou my vas Korporaal" in 1983 en Amanda Strydom se swartmag saluut in Stellenbosch in 1986. Kabarette soos Met Permissie Gesê in 1981 het ook op subtiele wyses die staat gekritiseer. Teen die einde van die 1980's was dit egter tyd vir 'n baie meer radikale benadering, waar die kabaret, Piekniek by Dingaan, die voortou geneem het. Die première was in 1988 by die Nasionale Kunstefees in Grahamstad en het die musiek van Johannes Kerkorrel en André Letoit ingesluit, en was 'n openlik ondermynde politieke teks wat die dominante verhaal van die NP en apartheid uitgedaag het. Volgens die filosoof Johan Degenaar was Piekniek by Dingaan die mees fundamentele postmoderne Afrikaanse teks van die 1980's, aangesien dit die grens tussen wat gesien is as "hoë kuns" en "populêre kuns" oorskrei het. Literêre skoliere Elize Botha en P.H Roodt skryf dat Piekniek by Dingaan:

\section{... met ligte aanslag heilige koeie slag, die waardes van 'n establishment dekonstrueer, hiërargiê omkeer, angels aan woorde teruggee, en intertekstualiteit met die taal en die liggaam illustreer. ${ }^{7}$}

Hierdie stelling illustreer duidelik hoe radikaal hierdie nuwe stroming van Afrikaner protes was en hoe radikaal dit verskil het van Musiek-en-Liriek en die kabaretvertonings wat daarmee geassosieer is. Laasgenoemde het doodeenvoudig nie so 'n vlak van ontwrigting bereik nie. In Piekniek by Dingaan is ou gunsteling Afrikaanse liedjies (soos Sonja Herholdt se "Waterblommetjies" en Randall Wicomb se "Dans met die rooi rok") verwerk en het óf politieke óf seksueel eksplisiete lirieke gekry. Dit was hoogs konfronterend en antagonisties, maar ook baie bevrydend vir Afrikaners wat in die konserwatiewe middelklas samelewing vasgesit het. Daar was 'n sterk band tussen Piekniek by Dingaan en Voëlvry - nie net het dit die musiek van Kerkorrel en Letoit gebruik nie, maar Willem Möller en Jannie van Tonder, lede van die Gereformeerde Blues Band, was ook in die rolverdeling. Toe die Voëlvry-toer minder as 'n jaar later afgeskop het, het hulle die boodskap en etos van Piekniek by Dingaan nog 'n stap verder gevat en dit vanuit die teater geneem na duisende mense reg oor die land. Hierdie konserte, veral op die platteland, het gedien as ontmoetingsplekke vir enersdenkende Afrikaners. In Clarens in die Oos-Vrystaat het die toer 'n skare mense gelok uit die omliggende dorpe waarvan talle buite die konsertsaal vir die eerste keer ander Afrikaanse mense wat net soos hulle gevoel het ontmoet en telefoonnommers uitgeruil het. ${ }^{8}$ So is nuwe netwerke van liberales in die konserwatiewe plattelandse dorpe gevestig. Dit is amper onmoontlik om die bande wat daar aangeknoop is op te spoor, maar - as 'n aanknopingspunt wat mense aangetrek het - was dit betekenisvol op maniere anders as Musiek-en-Liriek met hulle toegang tot TV en radio, of hulle

\footnotetext{
M. Du Preez, in Hopkins, Voëlvry, p. 6.

7 E. Botha en P.H. Roodt, "Die Tagtigers en die Tydskrif vir Letterkunde - was daar 'n Tagtigerbeweging?", Tydskrif vir Letterkunde, 43:1 (2006), p. 59.

8 Persoonlike kommunikasie met Willem Möller en Jannie van Tonder, Maart 2017.
} 
aartsvyande, die hoofstroom. Voëlvry was werklik ondergronds en sinvol omdat dit die energie van jarelange frustrasie kon inspan. Gevolglik het Voëlvry 'n spesiale plek gevestig in die geheue van dié wat dit sien gebeur het.

Moontlik nog belangriker as die kabaret Piekniek by Dingaan, was die invloed van Shifty Records, die klein onafhanklike platemaatskappy wat eerste die plate van Bernodus Niemand, André Letoit (soos hy destyds bekendgestaan het) en Johannes Kerkorrel uitgereik het. Lloyd Ross, die stigter van Shifty Records, het in die laat sewentigs by die Radio Rats, 'n invloedryke punk-groep, aangesluit en is blootgestel aan die ondergrondse punk scene in en om Johannesburg en Springs, ${ }^{9}$

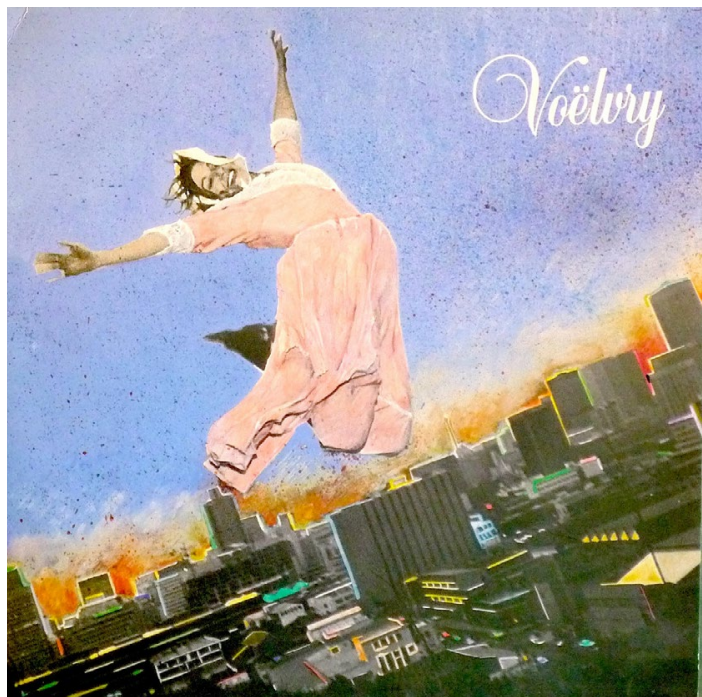

Shifty Records se Voëlvry-versameling van verskeie alternatiewe Afrikaanse kunstenaars, 1988 (SHIB 29). waar hy vir James Phillips (Bernoldus Niemand) ontmoet het. Sy toevallige ontmoeting met nog 'n punk-musikant, Ivan Kadey van die veelrassige punk-groep National Wake, het gelei tot die stigting van Shifty Records. Later het hy saam met Warrick Sony van die uitgesproke politieke groep, Kalahari Surfers gewerk. ${ }^{10}$ Aangesien nie veel ander platemaatskappye in Suid-Afrika in dié tyd (vroeë tot mid-1980's) bereid was om protesmusiek op te neem nie, het Shifty polities bewuste kunstenaars aangetrek. ${ }^{11}$ Hulle het'n eklektiese versameling van albums uitgebring, van die groep Sankomota uit Lesotho en Jennifer Ferguson, The Genuines, Vusi Mahlasela en Urban Creep, tot die "People's Poet" Mzwakhe Mbuli, die Fosatu Worker Choirs en versamelalbums wat die End Conscription Campaign gesteun het, soos Forces Favourites. ${ }^{12}$ In 1988 het Shifty 'n album met die titel Voëlvry uitgebring, met allerlei alternatiewe Afrikaanse kunstenaars, ${ }^{13}$ insluitend Niemand, Kerkorrel en Letoit. Dis opmerklik dat die Voëlvry-kunstenaars deel was hiervan.

Voëlvryhetegtergeen direkteband gehad met die internasionaleanti-apartheid-musiekbewegings wat met swart en bruin Suid-Afrikaanse kunstenaars in ballingskap geässosieer is nie. Oorsee het populêre musiekkonserte 'n belangrike rol gespeel om steun te werf vir die stryd teen apartheid. 'n Uitstekende voorbeeld hiervan is die 1988 Free Mandela-konsert in Wembley-stadion wat 'n skare van 72000 mense gelok het, en waar'n aantal internasionale sterre soos Peter Gabriel (wat sy treffer "Biko" gesing het) en Suid-Afrikaanse kunstenaars in ballingskap soos Miriam Makeba en Hugh Masekela opgetree het. Die konsert was 'n groot internasionale gebeurtenis, is in sestig lande uitgesaai en gesien deur byna 'n miljard mense. Dis opmerklik dat nie 'n enkele Afrikaanse

9 Hopkins, Voëlvry, p. 81.

10 Ibid., pp. 81-82, 87.

11 Ibid., p. 87.

12 Ibid.

13 Koos, Randy Rambo en die Rough Riders, Pieter van der Lugt, Die Kêrels, Khaki Monitor en The Genuines, 'n bruin ghoema punk-groep uit Kaapstad. 
kunstenaar daar opgetree het nie. ${ }^{14}$ Dié feit plaas uitsprake soos die volgende van Koos Kombuis in perspektief:

We wanted the same thing as freedom fighters - to be free. In that respect we knew about them and they knew about us. But our contribution to their cause must not be underestimated, because at a crucial point in history we took from government its greates power base, the youth. Never in their wildest dreams did the Bothas expect their own kids to turn against them and spit in their faces - and not with the gentle "loyal protest" envisaged by N.P. van Wyk Louw, mind you, but with real hatred, with all the pent-up rage our young hearts could muster.15

Hier verteenwoordig Kombuis, miskien onbedoeld, een uiterste pool van die diskoers rondom Voëlvry. Sy aanspraak - wat hy deel met baie van die deelnemers van die toer - dat hulle "die grootste magsbasis van die regering afgevat het", is 'n goeie voorbeeld. So ook sy aanspraak dat hulle bygedra het tot "hulle saak". Dit is moeilik om jou wit Afrikaanse kunstenaars as kamerade van die ANC-vryheidsvegters in die 1980's voor te stel, of om selfs te dink dat hulle hoegenaamd 'n invloed op die swart samelewing in Suid-Afrika gehad het. Albert Grundlingh het aangedui dat die beweging weinige sosiale invloede in die wit Afrikaner-samelewing self gehad het. ${ }^{16}$ Dat Voëlvry "in die staat se gesig gespoeg het" word egter nie betwis nie. Sulke rebellie teen die politieke sisteem vandag is egter nie so eenvoudig nie. Francois van Coke, die hoofsanger van Fokofpolisiekar, wat 'n groot aanhang van die ontnugterde stedelike Afrikaner jeug gekry het sedert hulle in 2003 op die been gekom het en nou die volgende generasie van Afrikaanse rockers van die 2000's verteenwoordig, het erken dat hulle as Afrikaners versigtig is om die regering te kritiseer ingeval hulle as rassisties sou oorkom. ${ }^{17}$ Gesien die kompleksiteite van post-apartheid Suid-Afrika, en weens Voëlvry se hertoetrede tot die openbare sfeer meer as 25 jaar later, is 'n herwaardering van die "beweging wat Suid-Afrika geruk het"18 nodig.

\section{Heroorwegings}

In April 2014 het 'n paneel van Afrikaanse musiekkenners bestaande uit skrywers, joernaliste en musikante, by die Klein Karoo Nasionale Kunstefees (KKNK), bymekaargekom om die belangrikheid van die Voëlvry-toer te bespreek en die 25ste verjaardag daarvan te vier. Vroeër, in Februarie, het die drie oorlewende lede van die Gereformeerde Blues Band - Willem Möller, Gary Herselman en Jannie "Hanepoot" van Tonder - saam op die verhoog verskyn by die Fïsta-toekennings, wat regstreeks op televisie uitgesaai is, ook in 'n gebaar van waardering vir die beweging. Dit was die eerste keer in meer as twee dekades dat al drie in dieselfde vertrek was. Hoewel hulle vir byna twee dekades lank meesal van die toneel af gebly het, het Shifty Records in September 2014 hulle dertigste verjaardag gevier met "Shifty September", 'n versameling musiek uit hulle argiewe wat die vertoning van regstreekse opnames deur polities subversiewe Suid-Afrikaanse musiekkunstenaars in die 1980's ingesluit het. ${ }^{19}$ Toevallig het dit

14 http://www.sahistory.org.za/dated-event/british-anti-apartheid-movement-hosts-concert-mandela [besoek 20 Januarie 2014].

15 Kombuis, aangehaal in Hopkins, Voëlvry, p. 19.

16 Grundlingh, "Rocking the boat?", p. 17.

17 https://www.youtube.com/watch?v=K_XekcXPBQs [besoek September 2014].

18 Om Hopkins aan te haal in Voëlvry, (Kaapstad, Zebra press, 2006).

19 https://www.facebook.com/shiftyseptember?ref=ts\&fref=ts [besoek September 2014]. 
ook met Voëlvry se verjaardag saamgeval, en 'n aantal panele en besprekings het plaasgevind ter viering van en gedagtenis aan dié mylpaal. Direkte verbande is getrek tussen Voëlvry en die post-1994 alternatiewe Afrikaanse musiekkultuur, spesifiek die Oppikoppi-fees en die groepe soos Fokofpolisiekar. ${ }^{20}$

Een van hierdie paneelbesprekings het kritiek opgeroep, met die aantyging dat wat eintlik 'n geleentheid vir "'n nie-rassige musiekkultuur was, het nie veel meer verteenwoordig as 'n steunpilaar vir Afrikaner Boheme en 'n liberale ontkenningspatologie nie". ${ }^{21}$ Tolsi en Gedye is beslis korrek in hulle opmerking dat die bespreking 'n wit aangeleentheid was. Watter ondermyning daar ook al onder die politieke Afrikaanse skrywers, musikante en toneelskrywers van die 1980's was, het hulle baie selde gebruik gemaak van die mees effektiewe wapen om die rassistiese bewind te ondermyn: samewerking met swart kunstenaars (daar was natuurlik uitsonderings, soos Jannie van Tonder van die Gereformeerde Blues Band wat in 1986 by die veelrassige African Jazz Pioneers aangesluit het). Die mees aanneemlike verklaring is dat hulle eenvoudig nie in dieselfde kringe as swart kunstenaars beweeg het nie, een van die einste beoogde resultate van die skeiding van rasse in die samelewing. ${ }^{22}$ Ander belangrike uitsonderings sluit David Kramer en sy samewerking met Taliep Petersen in, en Anton Goosen, wat met swart kunstenaars soos Lucky Dube en Yvonne Chaka Chaka saamgewerk het en in 1992 by die ANC aangesluit het. Nietemin het die kritiek op die ras van die besprekingsgroep betrekking op slegs 'n breukdeel van dít wat Voëlvry verteenwoordig het. Soos Gary Herselman, die baskitaarspeler van die Gereformeerde Blues Band, in een van die paneelbesprekings gesê het, was dit nie 'n inter-ras beweging nie, maar eerder 'n manier om teen hulle eie ouers en die samelewing en die politiek waarvoor hulle gestaan het, in opstand te kom, en te sê "Fok, man, daar moet 'n beter manier wees." ${ }^{23}$ Grundlingh stel voor dat hulle sukses te danke was aan die feit dat hulle Afrikaans was, maar dat dit 'n breër definisie, of 'n ander soort Afrikaans moes wees, een wat in pas was met "die eise van die tyd". ${ }^{4}$

Laubscher se dekonstruksie van Johannes Kerkorrel se musiek op die vlak van identiteit bied 'n nuttige insig in die uitrafelende magshorison van die laat-apartheid era en plaas die felheid waarmee die Voëlvry-kunstenaars die status quo aangeval het in perspektief. ${ }^{25}$ Ondanks die openlike hedonisme was die beweging geensins beperk tot skatologiese uitdrukkings van rebellie nie. Koos Kombuis was byvoorbeeld reeds 'n gepubliseerde skrywer toe Voëlvry begin het en gee openlik toe dat sy artistieke agtergrond in die literatuur lê, nie in musiek nie. ${ }^{26}$ Kerkorrel se verhoogdebuut was in 'n 1986 kabaret, Met ander woorde. ${ }^{27}$ Albei was betrokke by Piekniek by Dingaan. Van belang hier is dat Voëlvry, ondanks die punk-etiek wat baie aspekte van die beweging onderlê het, dit in 'n artistiese sin baie ryk was. Baie van die liedjies wat deur Voëlvry-kunstenaars geskryf is het klassieke Afrikaanse treffers geword, soos Kombuis se

20 https://www.youtube.com/watch?v=K_XekcXPBQs [besoek September 2014].

21 N. Tolsi en L. Gedye, www.theconmag.co.za/201/09/12/white-noise-and-lost-irony/ [besoek 15 September 2014], vertaal uit die oorspronklike.

22 https://www.youtube.com/watch?v=K_XekcXPBQs [besoek September 2014].

23 Ibid, vertaal uit die oorspronklike.

24 Grundlingh, "Rocking the boat?", p. 10.

25 Laubscher, "Afrikaner identity and the music of Johannes Kerkorrel”, pp. 308-330.

26 http://www.oulitnet.co.za/mond/kkramer.asp [besoek 5 Junie 2013].

27 I. Roggeband, 50 Stemme: Die grootste name in Afrikaanse musiek (Kaapstad: Delta, 2009), p. 135. 
"Lisa se Klavier" en Kerkorrel se "Hillbrow". Kerkorrel het postuum 'n SAMA in 2013 ontvang vir sy lewenslange bydrae aan die Suid-Afrikaanse musiek erfenis. ${ }^{28}$ Voor sy selfdood in 2002 het hy drie SAMA-toekennings ontvang.Terwyl kunstenaars soos Laurika Rauch, Anton Goosen en David Kramer kommersiële sukses bereik het met hulle vars idees in Afrikaans, het veral Bernoldus Niemand 'n ondermynde onderstroom verteenwoordig wat Kerkorrel en Kombuis beïnvloed het. Ongelukkig is Niemand se musikale nalatenskap kortgeknip deur sy dood in 1995 ná 'n motorongeluk tydens die Nasionale Kunstefees in Grahamstad. Sy werk word egter baie hoog deur musiekkritici geskat, hoewel hy nooit enige kommersiële sukses behaal het nie. Hoewel hulle musiek aansienlik verskil, het Niemand, Kerkorrel en Kombuis saam 'n formidabele en uiteenlopende aanslag op die status quo beteken, 'n feit wat Kerkorrel erken het:

I was intensely aware at the beginning of the movement that it would have to be a collaboration of a range of diverse artists to survive against the power of the state and censorship. ${ }^{29}$

Die Voëlvry-kunstenaars, saam met ander alternatiewe Afrikaanse groepe soos Joos Tonteldoos en die Dwarstrekkers, Die Kêrels en Randy Rambo en die Rough Riders het 'n ekstreme nuwe perspektief in Afrikaanse musiek verteenwoordig. Laasgenoemde se 1990-album Die Saai Lewe is in sy geheel verbied en nie 'n enkele liedjie op die plaat kon uitgesaai of versprei word nie. Dit is so subversief geag dat dit onwettig was om die album te besit, die enigste Afrikaanse plaat wat ooit hierdie status bereik het. ${ }^{30}$ Randy Rambo was die verhoognaam van Die Beeld se musiekkritikus Theunis Engelbrecht, 'n groot ondersteuner van die Voëlvry-kunstenaars.

Nog 'n faktor is dat die Voëlvry-kunstenaars meesal 'n ordentlike middelklas agtergrond gehad het - soortgelyk aan die kunstenaars in die VSA tydens die sosiale bewegings van die 1960 's. ${ }^{31}$ Dit het sterk afgesteek teen ander bewegings, soos punk in Britanje in 1976/77. Punk, wat duidelik 'n uitdrukking was van werkersklas belange, het die establishment hard getref. ${ }^{32}$ Hoewel die aanvanklike invloed van die beweging nie baie lank geduur het nie, aangesien dit byna onmiddelik sy legitimiteit kwytgeraak het toe dit deel van die hoofstroom geword het, ${ }^{33}$ was dit uiteindelik baie invloedryk in die vestiging van baie uitlopers soos new wave, post-punk en ska. Die Suid-Afrikaanse punk scene van die laat 1970's en 80's het aan die ander kant nie so 'n duidelike klasse-bewussyn getoon nie. Die dinamiek van Suid-Afrikaanse punk het ook op allerhande maniere van Brittanje s'n verskil, net soos die politiek van apartheid Suid-Afrika hemelsbreed van die politiek in Britanje verskil het. ${ }^{34}$ Hoewel daar'n los verband is tussen hierdie punk-groepe en Voëlvry, hoofsaaklik as gevolg van James Phillips se musiekverlede in groepe soos Corporal Punishment, het Voëlvry meer ooreenkomste met rock-musiek gehad. Twee dekades voor punk het rock-musiek 'n wêreldwye impak gehad, met uiteenlopende reaksies en motiverings. Joernaliste was die eerste om te reageer en 'n diskoers oor die invloed daarvan aan die gang te kry, en het dikwels opgemerk hoe rock-musiek in staat was om protesstemme

28 C. Leonard, "Johannes Kerkorrel: The wise fool who left the fray", Mail \& Guardian, 10 Mei 2013.

29 Johannes Kerkorrel, in Hopkins, Voëlvry, p. 231.

30 http://www.roekeloos.co.za/ritme/die-saai-lewe.html [besoek 6 Maart 2015].

31 Grundlingh, "Rocking the boat?", p. 4.

32 S. Frith, "Rock and the Politics of Memory", Social Text, 9:10 (1984), p. 61.

33 Ibid.

34 Vir in-diepte analise van die Suid-Afrikaanse punk-toneel van hierdie tyd, sien K. Jones en D. Maas se dokumentêr Punk in Africa (Pelogrosso: Meerkat Media, 2012). 
te dra, veral onder die jeug. In Suid-Afrika het rock-musiek soortgelyke reaksies in die pers uitgelok, ${ }^{35}$ en gedurende die volgende klompie dekades sou joernaliste nou betrokke raak by die ontwikkeling van musiekbewegings, hetsy as deelnemers of as kommentators.

\section{Die rol van joernaliste}

Voëlvry se hoogs ondermynende houding is gou opgemerk deur linkse Afrikaners, wat gereageer het met artikels in publikasies soos Vrye Weekblad, wat 'n borg van die toer geword het. ${ }^{36}$ Terwyl die meer liberale pers gereeld aandag aan die toer bestee het, is daar amper niks daaroor in Die Burger geskryf tot in middel-Mei, toe die Voëlvry-kunstenaars deur die destydse rektor van die Universiteit Stellenbosch, Mike de Vries, verbied is om op die universiteitskampus op te tree. Dit het gelei tot 'n ongewone sitstaking deur meer as 1500 studente, met 'n aantal personeellede wat by die betoging aangesluit het. ${ }^{37}$ Terwyl Die Matie (Universiteit Stellenbosch se studentekoerant) verslag gedoen het oor die betoging as 'n ondersteuning van vryheid van spraak, het Die Burger gefokus op 'n kleiner optog van studente wat die rektor ondersteun het. ${ }^{38}$ 'n Resensie van die konsert, wat by 'n alternatiewe plek weg van die kampus gehou is, was ten minste baie positief. ${ }^{39}$ Byna presies 'n maand voor die betoging en die daaropvolgende konsert, het Die Matie 'n meningsopname van musiekvoorkeure onder studente op kampus gedoen. Interessant genoeg het $40 \%$ nie na enige Afrikaanse musiek geluister nie (wat herinner aan soortgelyke opnames uit die 1970's onder die Afrikaner jeug), terwyl 22\% sporadies daarna geluister het. Onder die oorblywende $38 \%$ wat wel na Afrikaanse musiek geluister het, was die gewildste kunstenaars popsangers soos Anneli van Rooyen, Rina Hugo, Carike Keuzenkamp en Gé Korsten, terwyl 'n klein minderheid geluister het na David Kramer, Koos du Plessis en Jannie du Toit, wat deel van die Musiek-en-Liriek beweging was. ${ }^{40}$ Bles Bridges, moontlik die gewildste Afrikaanse sanger van die 1980's, was baie onpopulêr onder studente, met $72 \%$ wat hom gehaat het. Slegs $16 \%$ het na "alternatiewe Afrikaanse" musiek geluister, met 'n verdere $40 \%$ wat nog nooit daarvan gehoor het nie. ${ }^{41}$ Dit is belangrik, aangesien die sitstaking 'n maand later was. Hoewel 'n enkele kampusopname nie noodwendig metodologies onfeilbaar is nie, lyk die resultate baie soos die van soortgelyke opnames wat op ander kampusse gedoen is. ${ }^{42}$

Die meer liberale Afrikaanse publikasies het 'n baie kleiner leserspubliek gehad as die hoofstroom Afrikaanse pers. Soos met Musiek-en-Liriek was dit koerantjoernaliste wat Voëlvry eerste as 'n Afrikaanse musiekbeweging beskryf het. Hierdie neiging onder die gedrukte media om eerste nuwe musiek "bewegings" te erken, identifiseer en selfs te skep, is 'n algemene en noodsaaklike element in die kommersiële musiekbedryf. Wêreldwyd het musiekkunstenaars lank voordeel daaruit getrek om met die voorfront van nuwe musiekstyle geassosieer te word. Daar word dikwels 'n ophef gemaak voor 'n beplande nuwe uitreiking en dit verbeter 'n produk se kommersiële potensiaal. Simpatieke joernaliste by groot dagblaaie, soos Theunis Engelbrecht

35 C. Hamm, "Rock 'n Roll in a Very Strange Society", Popular Music, 5:1 (1985), pp. 159-174.

36 Du Preez, voorwoord in Hopkins, Voëlvry, pp. 6-8.

37 P. Joubert, "Protes vir vrye keuse", Die Matie, 11 Mei 1989.

38 “Talle Maties steun konsert-verbod”, Die Burger, 11 Mei 1989, p. 3.

39 E. Joubert, "J. Kerkorrel en sy Blues Band maak vriende", Die Burger, 15 Mei 1989.

40 V. Brand en L. Eloff, "Afrikaans musiek onbekend by student”, Die Matie, 13 April 1989, p. 6.

41 Ibid.

42 Grundlingh, "Rocking the boat?", p. 17. 
by Die Beeld, het baie publisiteit aan die Voëlvry-beweging verskaf, maar hulle kon nie - soos wat by Musiek-en-Liriek die geval was - toegang gee tot die hoofstroom verspreidingskanale nie. Dit sou een van die redes kon wees waarom Voëlvry 'n marginale groep gebly het. Koos Kombuis en Johannes Kerkorrel het relatiewe sukses bereik, maar James Phillips se albums was kommersiële mislukkings. ${ }^{43}$ Aan die ander kant van die musikale spektrum was die Afrikaanse pop hoofstroom radikaal anders, en die kloof het gou oorgespoel in 'n openlike vyandigheid in die pers.

\section{"Musiekoorloë"}

Dit was eintlik in die laaste dae van apartheid dat die media begin vrae vra het oor verskillende Afrikanernasionalistiese organisasies se pogings om ligte Afrikaanse musiek as 'n politieke werktuig te gebruik. In dié sin het die Voëlvry-beweging daarin geslaag om die banaliteit van hoofstroom Afrikaanse musiek bloot te lê. Hulle musiek het in skerp kontras gestaan teenoor die musiek wat die FAK, ATKV en SAUK ondersteun het. Hierdie kontras het betrekking gehad op lirieke, musiek en politiek. Hopkins dui aan dat die lekkerliedjies van die hoofstroom polities gemotiveer is, en dat die ontkenning hiervan deur die kunstenaars wat dit uitgevoer het, nie opreg was nie. Hoewel hierdie tipe Afrikaanse musiek die gewildste gebly het, het entoesiasme vir die lekkerliedjie teen die laat 1980's voldoende afgeneem om plek te mak vir meer ondermynde kunstenaars. ${ }^{44}$ Hierdie polarisering het dit baie duidelik gemaak: hoofstroom Afrikaanse popmusiek was opsetlik oppervlakkig en inskiklik met die ideologie van die apartheidstaat, terwyl die "alternatiewe" Afrikaners, Afrikaanse musiek gemaak het wat vir die eerste keer grootliks sosio-politieke kommentaar en kritiek op die Afrikanerdom gelewer het. Baie jong Afrikaners het in hierdie rebelle 'n nuwe legitimiteit vir Afrikaanse musiek ontdek, iets wat dekades vantevore verlore gegaan het, spesifiek weens die invloed van die base van Afrikanerkultuur.

Verskeie artikels in Insig en Vrye Weekblad het die kunstenaars van ligte Afrikaanse musiek (waaraan musiekkritikus Theunis Engelbrecht die term "LAM" toegeken het) ${ }^{45}$ geplaas teenoor die "alternatiewe" Afrikaanse musiekkunstenaars. ${ }^{46}$ Alternatiewe Afrikaanse kunstenaars is deur die intelligensiediens en polisie geïntimideer, terwyl die kunstenaars van ligte Afrikaanse musiek die steun van die SAUK geniet het op duur TV-programme soos Teletreffers, en in konserwatiewe koerante soos Die Transvaler verskyn het. ${ }^{47}$ Toe Anton Goosen die FAK se betrokkenheid by Afrikaanse musiek tydens 'n televisie-onderhoud op Goeiemôre Suid-Afrika skerp gekritiseer het, het die SAUK en Suid-Afrikaanse Televisie (SATV) hom vir ses maande

43 Hopkins, Voëlvry, p. 214.

44 Ibid., p. 68.

45 T. Engelbrecht: "Babapap vir bleeksiele", Die Beeld, 10 Augustus 1988, in Arnold, "Pomporrels, plaasromans en popmusiek", Insig, Desember/Januarie 1990, p. 43.

46 Sien A. Arnold se kolom "Boere-ritmes" in Insig, "Muurmusiek, potjiekos, Karoo-soul, techno-pop, en rou underground op een plaat", Januarie 1989, pp. 33-34; "Veertien uur se rock by Houtstok", Mei 1990, p. 37; “Kwêla laat die mure val!" September 1990, p. 39; “Pomporrels, plaasromans en popmusiek”, Desember/Januarie 1990/1991, p. 43; “Om van te lag ... of te huil: Afrikaanse plate plesiérig bekend gestel”, Mei 1991, p. 34; "Boem-boem, raai-raai, en sedes waai: niks skort met Afrikaanse sangers se seksdrif al sing hul ook van blomme", Junie 1991, p. 33; "Worsmasjien van kits-emosies maal voort" Februarie 1992, p. 39. Sien ook H. van Staden, "Afrikaanse Musiek: of op hok? Die bytjies, die blommetjies en big brother", Vrye Weekblad, 6-12 Maart 1992, pp. 13-15; en A. Vinassa, "Die boere het nie hul huiswerk gedoen nie”, Vrye Weekblad, 6-12 Maart 1992, pp. 17-18.

47 Van Staden, “Afrikaanse Musiek: Voëlvry of op hok? Vrye Weekblad, 6-12 Maart 1992, p. 14. 
verban. ${ }^{48}$ Bles Bridges het Goosen in 1990 selfs aangerand nadat hy op nasionale televisie verwys het na Bridges se veelbesproke buite-egtelike verhouding. ${ }^{49}$ Ligte Afrikaanse musiek het die establishment in al sy banaliteit verteenwoordig. Die FAK en SAUK het musiekkompetisies geborg waarvan die wenners oorvloedige ammunisie verskaf het vir die argument dat die hoofstroom Afrikaanse musiek totaal oppervlakkig was. Onsinnige lirieke was volop: ${ }^{50}$

Kom gryp die gevoel wat wikkel en woel in 'n byderwetse baadjie. Kom gryp die gevoel wat klink en krioel. Kom gryp dit gou, ou maatjie, en jy's in, en jy's in. Kom gryp die genot wat geselskap laat vlot, wat sorg vir super-ure. Kom gryp die genot wat sprankel en spot en speel om mal maniere en jy's in, en jy's in. Vir die byderwetse bekkie, vir die wakker wilde bul, vir die gryppitgenrasie, gryp dit gou en gil. Kom gryp die gebrul wat jou tone laat krul en klink oor kilometers. Kom gryp die gebrul wat vaal aande vul, maak los jou das en veters en jy's in, en jy's in.

Nog 'n voorbeeld, die lied "Omkeer", herinner aan wat Brendan Jury "afgesaagde en banale" Afrikaanse popliedjies noem: ${ }^{51}$

Sy kyk diep in my oë. Sy gee my weer 'n kyk. Dan lyk dit of sy kyk asof ek anders vir haar lyk. My arm is om haar skouers. Ek sê, "Ek wil met jou praat. Vanaand moet ons groet my maat! Môre is ek soldaat." Sy sê,,"Reg, jy het jou orders, gaan doen jou army ding. Gaan rol rond in die stof en sweet."52

Die FAK het probeer om guns onder die Afrikaner jeug te herwin deur populêre Afrikaanse volksliedjies in 'n moderner idioom te verwerk:

In 1985 verwerk Oom Dirkie weer etlike populêre liedere vir die Tweede FAK-Lekkersingliedjies. Die titels van die liedjies spreek vanself. Sproeitjies, ta Mosse se sakkie-sakkie boeredans, Waterblommetjies, Jantjie kom huis toe, Die trein na Matjiesfontein, Kinders van die wind, Kaalvoet in die reën - weereens musiek bedoel vir gebruik deur die breedste laag van die bevolking. ${ }^{53}$

Soos in 1976 was Dirkie de Villiers die FAK se verkose verwerker. Interessant genoeg is die meeste van die liedjies wat hier genoem word deur óf Anton Goosen óf Koos du Plessis gekomponeer, albei wie slegs vyf en 'n half jaar vroeër betrokke was by Musiek-en-Liriek. Hierdie pogings van die FAK was uiteindelik sonder sukses, en alternatiewe Afrikaanse musikante sou 'n groter rol speel om Afrikaanse musiek onder die jeug te bevorder. Goosen en ander Musiek-en-Liriek kunstenaars is swaar deur die Voëlvry-kunstenaars gekritiseer, en Dirkie de Villiers se verwerkings van hulle liedjies het aan die tweespalt bygedra. Max du Preez vertel dat Goosen gekritiseer is omdat hy geglo het die stelsel kan van binne verander word,

48 Ibid.

49 Onderhoud met outeur, Gansbaai, 29 April 2013.

50 Arnold, INSIG, Junie 1991, p. 33. Die skrywer van die liedjie is onbekend en dit is onseker of dit ooit opgeneem en vrygestel is.

51 Jury, “Boys to Men”, p. 100, van die liedjie "Omkeer" deur Louise du Toit Smit wat tweede gekom het in 'n liedjieskryfkompetiesie wat jaarliks deur die SAUK en ATKV aangebied is. Die lirkieke kan ook gelees word as propaganda vir diensplig.

52 Hopkins, Voëlvry, p. 50, van liedjie “Omkeer” deur Louise du Toit Smit.

53 A. le Roux, Handhaaf, April/Mei, 1988, p. 6. 
terwyl Voëlvry dit heeltemal wou vernietig. ${ }^{54}$ Terwyl dié stelling tussen die twee kampe alternatiewe Afrikaanse musikante differensieer, probeer hulle tog op 'n manier saamstaan om 'n alternatiewe musiekvorm te verteenwoordig, wat teen die oppervlakkige pop hoofstroom is. Dit herinner ons ook aan André Du Toit se intellektuele kritiek in Die sondes van die vaders. Hier is die regmatigheid van 'n binnekring se kritiek teen die Afrikaner establishment bevraagteken op grond daarvan dat die hele stelsel moreel korrup was en dat fundamentele verandering nodig was. ${ }^{55}$ Teen die tyd van Voëlvry en die eerste Houtstok-konsert die jaar daarna het Goosen egter baie meer polities uitgesproke geraak as wat hy teen die einde van die 1970's was.

Die vyandigheid tussen die FAK, die kulturele en godsdiensorganisasies wat daarmee geaffilieer is, en die alternatiewe Afrikaanse musiekkunstenaars was ernstig genoeg om June Goodwin en Ben Schiff daarna te laat verwys as "musiekoorloë." ${ }^{56}$ Die grense tussen die twee kampe was duidelik: die FAK, SAUK, Decibel-platemaatskappy en kunstenaars soos Bles Bridges, Danie Botha en Innes en Franna Benade aan die een kant; en kunstenaars soos Johannes Kerkorrel, Anton Goosen en Koos Kombuis, en publikasies soos Vrye Weekblad aan die ander kant. Die eerste groep (LAM) het meer as net 'n musiekgenre verteenwoordig. Hulle is uitgebeeld as goedgesind teenoor die bewind, totaal oppervlakkig en heeltemal uit voeling met die realiteit van die Suid-Afrikaanse politiek. Verder is hulle daarvan beskuldig dat hulle aktief en opsetlik Afrikaanse musiek van so 'n lae standaard geskryf, opgeneem, bevorder en uitgesaai het dat dit die Afrikanerkultuur erg beskadig het. Om geen politieke standpunt in te neem nie het self 'n politieke standpunt geword tydens die noodtoestand in die 1980's, soos duidelik is uit die volgende uitspraak deur Bles Bridges in 1988:

Ek hoef nie die nasie se brein met politieke inligting te besoedel met my liedjies
nie. Ek wil oor die mooi dinge sing. Oor die positiewe dinge sing. Want 'n positiewe
nasie, is 'n produktiewe nasie en ' $n$ nasie wat vir mekaar iets kan beteken. ${ }^{57}$

LAM kunstenaars het hoofstroom Afrikaanse musiek gedomineer en het sterk bande gehad met invloedryke konserwatiewes in die media, kerk en regering, en het hulle invloed gebruik om hulle teenstaanders te intimideer. Hulle het transkripsies van aanstootlike lirieke aan die konserwatiewe koerante gestuur om so publieke verontwaardiging teen die alternatiewe Afrikaanse kunstenaars aan te wakker. Anton Goosen vertel dat die kantore van die FAK, die Broederbond en Brigadiers almal in dieselfde gebou was. ${ }^{58}$ David Kramer het 'n paar jaar vroeër in 1985 die verpakking van hoofstroom Afrikaanse musiek op televisie gekritiseer toe hy sy weersin uitgespreek het in “ ... die tipe kabaret-kunstenaars wat gegiet word volgens die vorm en aspirasies van 'n Liza Minelli ... wat fokus om half-skouspelagtige vertonings te probeer produseer wat gebasseer is op die Amerikaanse model van afstap by 50 trappies, blinkers en glans" ${ }^{59}$ Liberale joernaliste was onwrikbaar in hulle kritiek teenoor LAM. In 'n artikel in

54 Hopkins, Voëlvry, p. 57.

55 A du Toit, Die sondes van die vaders (Kaapstad: Rubicon Press, 1983).

56 J. Goodwin en B. Schiff, Heart of Whiteness: Afrikaners face black rule in the New South Africa (New Nork, Scribner, 1995), pp. 174-183.

57 L. Ross, Voëlvry: the Movie, Shifty Studios, DVD 2006.

58 Onderhoud met outeur, Gansbaai, 29 April 2013.

59 "Kramer - the man no one (except) SATV can ignore", The Friend, in M. Slabbert en D. de Villiers, David Kramer 'n Biografie (Kaapstad: Tafelberg, 2011), p. 196. 
Vrye Weekblad verskaf die joernalis Hanneli van Staden die volgende insigte in maniere waarop Afrikaanse musiek van sy lusteloosheid "genees" sou kon word:

Die SAUK kan 'n deurslaggewende rol speel, maar om duistere redes bevoordeel hy net sekere kunstenaars en maatskappye - opvallend genoeg Decibel ... Daar is geen salf te smeer aan instansies soos die FAK en ATKV nie. In die oorgangsfase waarin Suid-Afrika hom nou bevind, is hulle heeltemal irrelevant. Hulle het die Afrikaanse kultuur boonop al genoeg skade aangedoen deur dit in 'n laager te bondel en te vertroetel soos 'n pasiënt met 'n dodelike siekte. Die monopolie van MFP en Decibel moet einde kry. ${ }^{60}$

\section{Houtstok teenoor die FAK}

Die vyandigheid tussen die alternatiewe Afrikaanse pers en die kunstenaars wat met hulle geassosieer is en die Afrikaanse pop hoofstroom het op 31 Mei 1990 'n hoogtepunt bereik:

The occasion was dubbed Houtstok - Woodstock in Afrikaans - taking its name and inspiration from the American rock festival that symbolized youthful liberation in 1969. Houtstok offered the Afrikaners present a joyful repudiation of their inherited image as a conservative people intolerant of racial differences and resistant to progress. ${ }^{61}$

Die fees is by die Le Château-landgoed buite Pretoria gehou en is bedoel as 'n alternatief vir die FAK se Republiekdag musiekfees, wat op dieselfde dag nie ver daarvandaan by die Voortrekkermonument plaasgevind het nie. ${ }^{62}$ By die monument, die heiligste van alle Afrikaner plekke, het 'n ander skare Afrikaners vergader om die 39 jaar van die Suid-Afrikaanse republiek te vier. Die FAK se fees was self ook omstrede. Die organiseerders het geëis dat die kunstenaars moet mime op vooropgeneemde musiek om so klankprobleme te vermy wanneer die konsert op die televisie uitgesaai word. ${ }^{63}$ Dit was blykbaar geen geheim nie, soos een lid van die gehoor in Pretoria vertel het:

Ek wil die sangers in die oë kyk. En dit maak nie saak of hulle nie rêrig, rêrig sing nie, want die gesigte is darem daar," terwyl haar man gesê het: "Dis ons volk se mense. Ek is hier vir Gé Korsten. ${ }^{64}$

Die identifikasie van Gé Korsten as deel van die "volk se mense" resoneer met die volkseie teenoor volksvreemde idee. Die verskil tussen die gehore by die twee konserte was net so groot soos die verskil tussen die kunstenaars wat opgetree het. Johannes Kerkorrel was nie by Houtstok nie aangesien hy toe op toer in België en Nederland was, maar hy was ook teësinnig om deel te neem, waarvoor die organiseerders van die fees hom erg voor kwalik geneem het. ${ }^{65}$ Behalwe vir die botsings van persoonlikhede dui dit ook daarop dat daar nie 'n leiding in die alternatiewe Afrikaanse musiekbeweging was nie. Voëlvry was sonder twyfel 'n inspirasiebron

60 Van Staden, “Afrikaanse Musiek: Voëlvry of op hok?”, Vrye Weekblad, 6-12 Maart 1992, p. 15.

61 New York Times, 4 Junie 1990, aangehaal in S. Hofmeyr: Mense van my Asem (Kaapstad: Zebra Press, 2008), p. 121.

62 A. Arnold, "Veertien uur se rock by Houtstok", Insig, Mei 1990, p. 37.

63 Ibid.

64 M. Ley, “Mimiekmusiek by die monument”, Die Burger, 2 Junie 1990.

65 B. Hough, "Vir die 'Orgel” sê mens nie 'Sit dit af' nie!”, Rapport, 17 Junie 1990, p. 5. 
vir dié konsert, maar die live dubbelalbum wat uit die konsert gespruit het, bevat slegs een liedjie van 'n Voëlvry-kunstenaar (Koos Kombuis se "Ou Tannie Blues"), terwyl die res 'n baie wyer verskeidenheid alternatiewe Afrikaanse en Engelse kunstenaars verteenwoordig het. ${ }^{66}$

Ietwat onverwags was Die Briels een van die gewildste groepe by Houtstok - met 'n optrede deut Tant Sannie Briel saam met haar twee kinders, vir die eerste keer in dekades. ${ }^{67}$ Sannie Briel se aanwesigheid by die konsert het vreemd gelyk aangesien Houtstok strenggesproke 'n "alternatiewe" musiekfees was met kunstenaars van die liberale nuwe golf, waarmee Die Briels geen direkte band gehad het nie. Maar toe tant Sannie, haar seun Frans en dogter Anita die verhoog betree het 'n skare van 20000 mense "Ouma Sannie, Ouma Sannie” bly roep. Die Briels was nie juis rockers nie en op een stadium het die skare selfs saamgesing met "How much is that doggy in the window". Hulle het ook nie Koos Kombuis se kru taalgebruik waardeer nie. ${ }^{68}$ Maar Johannes Kerkorrel was, toe hy gevra is oor sy afwesigheid van die fees, oor niks spyt nie behalwe dat hy Die Briels gemis het, van wie hy blykbaar 'n groot aanhanger was. ${ }^{69}$

Sannie Briel het nie eens op die lys van kunstenaars wat by Houtstok sou speel, in 'n artikel in Insig, verskyn nie (Kerkorrel het). ${ }^{70}$ Miskien is Die Briels by die kunstenaars van die konsert toegevoeg as 'n karikatuur van die 1950's en 1960's, hoewel hulle, op die toppunt van hulle sukses, soos voorheen genoem, 'n seldsame werkersklas alternatief gebied het tot die opera-agtige Afrikaanse popmusiek met sterk Europese invloede van sangers soos Gé Korsten. Vir die skare by Houtstok het Die Briels waarskynlik 'n mengsel verteenwoordig van iets in 'n ligter luim, 'n aanvaarbare vorm van Africana, uitgestotenes soos hulle self, en miskien ook 'n vreemde ongerymdheid by so 'n konsert, wat in 'n goeie gees ontvang is. Hulle het moontlik ook ingespeel op 'n soort nostalgie wat vry was van die bagasie van apartheid, wat in skerp kontras was met die soort nostalgie wat die FAK-konsert die dag ook opgeroep het. Hierdie spel met nostalgie is 'n belangrike deel van post-apartheid Afrikaanse musiek wat in Hoofstuk Sewe verder bespreek word.

Houtstok was'n groot risiko in 'n tyd toe regse militêre Afrikaner organisasies op hulle gevaarlikste was. 'n Ramp is afgeweer toe die polisie twee kleefmyne wat deur regse Afrikaners onder die verhoog geplaas is, ontlont is. ${ }^{71}$ Soos wat Anton Goosen onthou, was die veiligheidspolisie by sulke konserte ook nooit ver weg nie:

\section{Dit het nog seriously voortgegaan met Houtstok. Nou Houtstok was na dieVoëlvry ding. Ek meen Voëlvry het toe al klaar hulle moeilikheid opgetel en of hulle nou baie hype by dit gesit het of nie, daar was moelikheid. Daar was definitief moeilikheid. En tot en met Houtstok, want Houtstok was 'n direkte konfrontasie tussen die nuwe Afrikaner wat so voel, en die ou ene by die Voortrekker monument wat dieselfde dag op Republiekdag (3I Mei 1990) feesvier. Die FAK, backtracks, lollipops, uhm spookasem eet, gesinspret ens. Blink skoene, wat jy nie van moet vergeet nie. And}

66 Sien Figuur 19.

67 T. Engelbrecht, "Kranse dreun, maar Ouma Briel kom weer”, Die Burger, 2 Junie 1990.

68 Frans Briel, in 'n onderhoud met Engelbrecht, "Kranse dreun, maar Ouma Briel kom weer”, Die Burger, 2 Junie 1990.

69 Hough, “Vir die 'Orgel” sê mens nie 'Sit dit af' nie!”, Rapport, 17 Junie 1990, p. 5.

70 Arnold, "Veertien uur se rock by Houtstok", Insig, Mei 1990, p. 37.

71 Anton Goosen, Gansbaai, 29 April 2013, bevestig deur Peter Pearlson, klankingenieur by die konsert, Strand, 11 April 2014. Sien ook T. Engelbrecht, Houtstok: Die verhaal agter die verhaal, (Melville: Musiek SA, 1990), p. 4. 
we beat them. Daar was 22000 mense by Houtstok en daar was 16000 mense by

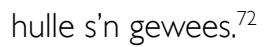

Goosen som die spanning tussen die nuwe golf van Afrikaanse musiek en die ou garde uitstekend op. By die konsert het hy sy liedjie "Wit Kaffers van Afrika" gesing. ${ }^{73}$ Net die titel van die lied ondermyn al die rasse- en klassebeginsels waarop die Afrikaner-samelewing geskoei is, so effektief dat die boodskap volkome ondubbelsinnig is: 'n groep jong Afrikaners het weggebreek - hulle identifiseer nou self as "Afrikane"/“ander".

Steve Hofmeyr, wat een van die gewildste

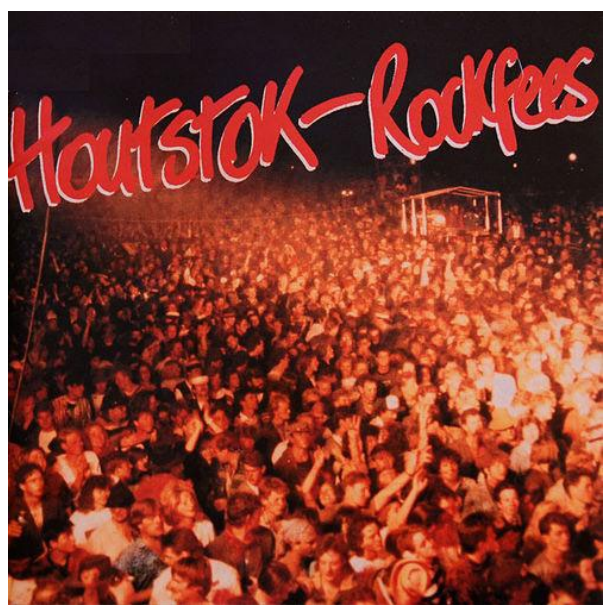

Album opgeneem by Houtstok (Gallo HOUT I). Afrikaanse sangers ooit sou word, het by sowel Houtstok as die FAK-konsert opgetree. Hofmeyr is egter daarvan beskuldig dat hy albei kante probeer tevrede hou, dit nadat hy Bles Bridges op die televisieprogram Debuut "getrou" het, en ook deur die FAK as "alternatief" geadverteer is voor 'n groot konsert in 1991. Laasgenoemde strategie was 'n doelbewuste poging om die konsert onder die aandag van 'n jonger generasie Afrikaners te bring, maar dit het slegs daarin geslaag om Hofmeyr in die kamp van ligte Afrikaanse sangers te plaas, ${ }^{74}$ iets waarvoor hy later dankbaar sou wees. Soos hy verduidelik:

... (M)aar later was ek dankbaar dat die Afrikaanse ligtemusiekwêreld grootliks ongedeerd van geïnstitusionaliseerde polities korrekte bedreigings en kleinlike gesindhede afgekom het. $^{75}$

Hoofstroom Afrikaanse popmusiek het tot vandag toe goed bly verkoop, ${ }^{76}$ terwyl die meer alternatiewe Afrikaanse groepe sukkel om selfs 'n breukdeel soveel plate te verkoop. Soos wat die volgende hoofstuk sal aandui, bevat die konserwatiewe houding van die Afrikaanse hoofstroom natuurlik baie ander betekenisse en uitdagings in post-apartheid Suid-Afrika. Houtstok 2 het in 1992 plaasgevind en het weer 'n groot skare gelok. Hofmeyr het nie dié keer opgetree nie, maar hy was by daardie jaar se FAK-konsert. Hoewel die post-apartheid jare belangrik is in studies oor Afrikaner-identiteit, dui die spanning tussen die sensuurraad, die FAK

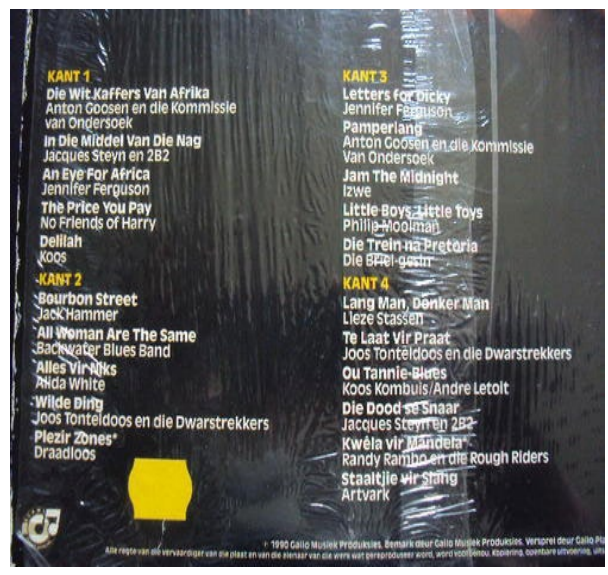

Snitte op Houtstok-album.

72 Goosen, Gansbaai, 29 April 2013.

73 Ibid., die liedjie verskyn ook op die album wat by die konsert opgeneem is.

74 Arnold, "Kom gryp die gebrul wat jou tone laat krul”, Insig, Julie 1991, p. 34.

75 Hofmeyr, Mense van my asem, pp. 119-120.

76 Sien Hoofstuk Sewe. 
(en hulle kunstenaars) en die kunstenaars wat hulle uitgedaag het op'n diep kloof in die Afrikanersamelewing teen die einde van apartheid. Voëlvry en Houtstok verteenwoordig die laaste fase van politieke Afrikaanse musiek wat, hoewel dit uitsluitlik wit was, die ideale van die nuwe Suid-Afrika gesteun het. Post-apartheid politieke Afrikaanse musiek roep byna onvermydelik spanning op wanneer dit die regering kritiseer. As 'n bevoorregte minderheidsgroep met 'n moeilike verlede, vermy meer liberale Afrikaanse kunstenaars soos Fokofpolisiekar politieke kommentaar, ingeval hulle as rassisties gesien word, en hulle distansieer hulleself van dié kunstenaars wat openlik betrokke is by ras en politiek. Laasgenoemde groep - met Steve Hofmeyr aan die hoof - word dikwels van haatspraak beskuldig, wat die aanvaarbare grense van artistieke vryheid in 'n multikulturele samelewing in die gedrang bring. Voëlvry se Suid-Afrika was vinnig aan die verander, en hulle kritiek op die Afrikaner-samelewing is deur die groter Suid-Afrikaanse publiek verwelkom (of ten minste gedeel). Hulle politieke vyandigheid was 'n kleurryke stem in die laaste dae van apartheid, maar twintig jaar ná apartheid het Afrikaner politieke weerstand 'n baie ander dinamiek en betekenis. 


\section{HOOFSTUK SEWE}

\section{Nostalgie, vrees en wins in post-apartheid Afrikaanse musiek}

Teen die tyd wat hierdie boek geskryf is het die post-apartheidsera reeds jong volwassenheid bereik en op 23 jaar oud bly dit steeds verander teen 'n vinnige tempo. Suid-Afrika is in 2017 heel anders as die Suid-Afrika van 2007, of 1997. Die dokumentêre film Kom laat ons sing van 2003 het die eerste dekade van die post-apartheidsera uitgebeeld as een waarin Afrikaanse musiek bevry is van die kloue en beperkings van die apartheid regime. Die daaglikse sensuur en politieke (en gemeenskaplike) beperkings was iets van die verlede - en is vervang deur'n toneel waar kunstenaars kon 'asemhaal' en hulleself meer vryelik kon uitdruk. En baie van hulle het die geleentheid aangegryp. As dit vergelyk word met hoe beperk die bedryf in die apartsheid-era was in terme van die aantal kunstenaars, produksies en oorspronklike komposisies, het die post-apartheid Afrikaanse musiekbedryf meer vooruitsigte en geleenthede gebied. Dit blyk egter nie of daar 'n groot reaksie was in Afriaanse musiek met die oorgaan na 'n demokrasie nie. In plaas daarvan het die veranderinge wat wèl plaasgevind het, selfs voor 1994 geleidelik begin gebeur. Teen 1992 het CDs plate vervang en in die volgende paar jaar het platemaatskappye goed geld gemaak deur ouer Afrikaanse treffers in hierdie nuwe formaat uit te reik ('n proses wat reeds in die laat 1980 's begin het $)^{1}$, 'n geleentheid wat niks met die politieke veranderinge van die tyd te make gehad het nie. Party kunstenaars het die nuwe, oop kulturele sfeer aangegryp deur met swart Afrikaanse kunstenaars saam te werk, soos Anton Goosen wat Lucky Dube

1 Pretorius, telefoniese onderhoud met outeur, 22 Julie 2013. Bles Bridges het die eerste Afrikaanse CD in 1987 uitgereik, en die druk van vinielplate is beëindig in September 1992. Voorbeelde hiervan sluit in TEAL se Afrikaanse Goue Jare Vol. 1 \& 2 in 1996, wat versameling-albums van Afrikaanse treffers oor dekades was. 
betrek het vir sy 1992-album Danzer. Die eerste groot post-apartheid Afrikaanse trefferplaat was Leon Schuster se Hier kommie Bokke, wat met 'n rugby-tema munt geslaan het uit die Wêreldbeker-rugbytoernooi in 1995 (wat in Suid-Afrika plaasgevind het) en waarvan ongeveer 275000 eenhede verkoop is. Hierdie verkope is ongetwyfeld aangehelp deur die euforie toe Suid-Afrika as wêreldkampioene gekroon is, iets wat deur die hele land gesamentlik gevier is.

Een prominente uitwerking van die demokratiese oorgang was egter dat die amptelike status van Afrikaans verminder is van een van twee amptelike tale (saam met Engels) na een van elf. Die befondsing wat die staat aan die Afrikaanse kunste voorsien het, het tot 'n einde gekom toe die vier provinsiale kunsterade in dieselfde jaar ontbind is. ${ }^{2}$ Dit het gelei tot die stigting, in 1995, van die Klein Karoo Nasionale Kunstefees (KKNK) as 'n toevlug vir die Afrikaanse kunste, ${ }^{3}$ hoewel sommige kommentators opmerk dat dit eintlik 'n toevlug vir wit Afrikaanse kultuur geword het, gebaseer op die demografiese profiel van die feesgangers. ${ }^{4}$ Van toe af het Suid-Afrika 'n toename in kunstefeeste regdeur die land gehad. Die meer alternatiewe Oppikoppi-fees is in 1994 gestig en staan sedertdien uit as 'n toonplek van multi-kulturele Suid-Afrikaanse (en meer streeksgebonde) musiek. Teen die einde van die dekade en aan die begin van die volgende een het 'n nuwe golf van Afrikaanse pop egter die radiogolwe getref met kunstenaars soos Juanita du Plessis en Kurt Darren as die nuwe groot name. 'n Mens kry egter die gevoel dat die groei wat wel plaasgevind het, baie min met vryheid te make gehad het, en meer met bemarking en ander algemene tendense soos wat die tegnologie ontwikkel het.

Populêre Afrikaanse musiek is een van die topverkopende plaaslike genres in die Suid-Afrikaanse musiekmark sedert die dae van Chris Blignaut en David de Lange in die 1930's (en moontlik selfs vroeër). Selfs teen hierdie historiese standaarde gemeet, was die 21 ste eeu tot dusver 'n goue era vir Afrikaanse kunstenaars. Dis moeilik om presiese syfers te kry, maar dit het waarskynlik gefluktureer tussen $30 \%$ en $40 \%$ van alle plaaslik-vervaardigde musiekverkope, insluitend musiek wat in ander tale uitgereik is. Steve Hofmeyr (Toeka, 2004), ${ }^{5}$ Lianie May (Boeremeisie, 2009), ${ }^{6}$ Bok van Blerk (Afrikaner Hart, 2010), ${ }^{7}$ Theuns Jordaan (Roeper, 2013) ${ }^{8}$ and Riana Nel (Die Regte Tyd, 2015) ${ }^{9}$, het elk 'n Suid-Afrikaanse Musiektoekenning (SAMA) vir die besverkopende Suid-Afrikaanse album van die jaar gewen. Verder was, benewens Theuns Jordaan se sukses met Roeper, die vyf albums wat in die 2012/2013-periode die beste in Suid-Afrika verkoop het almal Afrikaans. Riana Nel se Die moeite werd (87 000 kopieë), Jay en Lianie se Bonnie en Clyde (80 000 kopieë), Bobby van Jaarsveld se Wat geld nie kan koop nie (80 000 kopieë) en Juanita du Plessis se Jy voltooi my (70 000 kopieë) het meer as enige ander genre verkoop in 'n tyd waarin die tradisionele plate-industrie toenemend bedreig is deur

2 H. Kitshoff, "Die opkoms, dinamika, en betekenis van die Klein Karoo Nasionale Kunstefees: 1995-2005", DPhil Thesis, Universiteit Stellenbosch, 2005, p. vi. Sien ook Jury, “Boys to Men”, p. 101.

3 Kitshoff, "Die opkoms, dinamika, en betekenis van die Klein Karoo Nasionale Kunstefees: 1995-2005”, p. vi.

4 T. Hauptfleisch, "Eventification: Festivals and the making of a theatrical event", South African Theatre Journal, 15 (2001), p. 6. Natuurlik het feeste oor die jare ontwikkel en het dit onlangs 'n meer inklusiewe strategie begin volg.

5 http://www.channel24.co.za/Music/News/SAMA-audience-boos-Steve-Hofmeyr-20110523 [besoek20 Julie 2013].

6 http://beta.mnet.co.za/ChannelO/ChannelArticle.aspx?AId=15541 [besoek 20 Julie 2013].

7 http://www.channel24.co.za/Music/FeaturesInterviews/2010-SAMA-Winners-20100414-2 [besoek 20 Julie 2013].

8 M. Malan, "Samas-sukses", Rapport, 12 Mei 2013, p. 3.

9 http://www.sowetanlive.co.za/entertainment/2015/04/20/xxi-south-african-music-awards-samasphotos [besoek 28 Mei 2015]. 
die digitale aflaai van musiek. ${ }^{10}$ Tot op hede het Steve Hofmeyr meer as twee miljoen albums verkoop, ${ }^{11}$ so ook Juanita du Plessis, ${ }^{12}$ wat haar die topverkopende Afrikaanse vrouekunstenaar in die geskiedenis maak. Dit is merkwaardige syfers, veral as mens dink aan hoe relatief klein die mark is. Daar is ook ' $n$ hele aantal ander kunstenaars wat honderde duisende albums verkoop. Dit getuig van 'n baie gesonde bedryf.

Arnold Coleske (van Coleske Artists, organiseerders van die ontsettend gewilde Afrikaans is Groot Konserte (AIG)) skryf hierdie suksesse toe aan die gehalte van die musiek: Afrikaanse luisteraars eis Afrikaanse musiek van goeie kwaliteit, en hierdie Afrikaanse kunstenaars hou aan om dit te bied. ${ }^{13}$ Nog 'n moontlike verklaring is dat die veranderende demografie van die kopers van Afrikaanse musiek gelei het tot 'n aansienlike toename in verkope. Soos voorheen genoem het die Afrikaanse jeug van die 1950's tot die laat 1980's nie werklik na Afrikaanse musiek geluister nie. Met die einde van apartheid en die begin van die 1990's het Afrikaanse studente en tieners na Afrikaanse albums begin luister en dit begin koop. ${ }^{14}$ Dit het ook makliker en goedkoper geword om albums op te neem, wat beteken het dat daar 'n beduidende toename in die aantal albums was wat op die mark uitgereik is. Sonder die beperkings van die SAUK en met die gedrukte media wat hulle op 'n jonger mark rig, het verkoopsyfers aansienik gegroei. Die aanvraag-kant van die musiekbedryf is ook interessant. Wat motiveer mense om soveel Afrikaanse albums te koop? Afrikaanse musiek word op Afrikaanse televisiekanale, aanlyn, en in die gedrukte media bemark, en musiekwinkels wat produkte ondersteun (alles van kommersiële produkte soos klere en karre, tot kerke, skole, en behuisingsontwikkelings) het alledaags geraak. Sosiale media veral het 'n toenemend belangrike platform geword waar kunstenaars hulle profiele kan bevorder. Die top tien Afrikaanse musiekkunstenaars, suiwer volgens Facebook likes $^{15}$ beoordeel, is:

1. Steve Hofmeyr - 402568

2. Juanita du Plessis - 337485

3. Bobby van Jaarsveld - 307275

4. Karlien van Jaarsveld - 290764

5. Lianie May - 251814

6. Bok van Blerk - 196863

7. Jack Parow - 184729

8. Die Heuwels Fantasties - 181374

9. Kurt Darren - 139866

10. Jay du Plessis - 132093

10 Malan, “Samas-sukses", Rapport, 12 Mei 2013, p. 3.

11 Elektroniese kommunikasie met outeur, 5 Augustus 2013; sien ook http://stevehofmeyr.co.za/website/biographyparent?showall=1 [besoek 21 Julie 2013].

12 http://www.juanitaduplessis.com/ [besoek 21 Julie 2013].

13 Ibid.

14 Boet Pretorius, telefoniese onderhoud met outeur, 22 Julie 2013, sien ook Hoofstuk Drie se bespreking van FAK meningspeilings.

15 Toegegee, dit is nie 'n akkurate aanduiding van steun nie en is slegs hier ingesluit as 'n vorm van anekdotiese bewyse. Dit is egter waarskynlik akkurater as Twitter, aangesien mense gewoonlik beroemdes volg nie net omdat hulle, hulle ondersteun nie, maar ook omdat hulle nuuskierig is oor wat hulle volgende gaan twiet. Nie almal wat Steve Hofmeyr op Twitter volg deel ook sy sienings nie, hoewel hulle waarskynlik nie sy Facebook-bladsy sal volg nie. Hierdie syfers dateer van 7 Maart 2017. Die Antwoord - Suid-Afrika se beroemdste/berugste musiek uitvoerproduk - is nie hier ingesluit nie aangesien hulle meesal buite Suid-Afrika aktief is en hulle aanhangers baie meer divers is. Hulle het byna 2,5 miljoen Facebook likes, ongetwyfeld van regoor die wêreld. 
Hierdie syfers weerspieël nie noodwendig verkope nie. Theuns Jordaan het byvoorbeeld 'n relatief lae aanlynprofiel, maar hy verkoop baie plate. Dit is veelseggend dat Afriforum, die Afrikaanse burgerregte organisasie met waarskynlik die grootste Afrikaner gevolg, 199343 likes het. Solidariteit, nog 'n Afrikaanse organisasie, het 131 522. Dit sê waarskynlik nog meer dat Emo Adams 34712 likes het - meer as enige ander bruin Afrikaanse kunstenaar.

Maar daar is blykbaar ook ander faktore in hierdie suksesstorie. Theuns Jordaan skryf dit toe aan die lojaliteit van die Afrikaanse publiek en hulle voorkeur vir tasbare kopieë bo afgelaaide musiek. Hy is dalk reg, maar hierdie lojaliteit het verskillende dimensies. Sonder'n daadwerklike ondersoek onder musiekkopers, kry'n mens die gevoel dat die blote feit dat dit in Afrikááns is, 'n aansienlike aantal kopers motiveer. Dit sluit aan by die vermoede dat hierdie groter kulturele inkoop op die een of ander manier verband hou met die persepsie dat die Afrikaanse kultuur (en Afrikaanse musiek daarmee saam) werklik bedreig word, en as die publiek dit nie voldoende steun nie, dit in 'n multi-kulturele Suid-Afrika sal verdwyn. Steve Hofmeyr deel 'n nuttige insig:

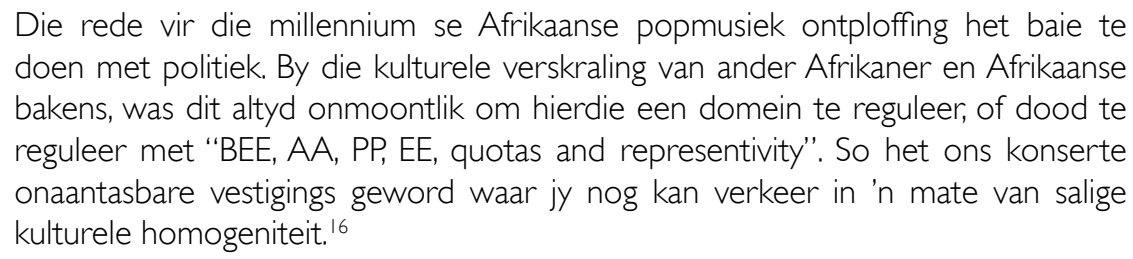

Die situasie het in die laaste jare ietwat verander vanweë die toenemende prominensie van die (wettige en onwettige) aflaai van musiek, asook platforms waar musiek ge-stream kan word wat 'n negatiewe impak op CD-verkope gehad het. Kunstenaars soos Karen Zoid het die aanlyn-musiekwêreld met groot sukses genavigeer, maar hierdie moeiliker omstandighede het ander gedwing om meer artisties konserwatiewe albums uit te reik, waarin hulle bewese formules gebruik eerder as om innoverend te wees. Daarby word Afrikaners, soos wat politieke spanning in Suid-Afrika styg, meer aggressief in hulle afbakening van kulturele "domeine", wat dikwels elemente van nostalgie van "die ou dae" bevat. Die gebruik van nostalgiese temas in Afrikaanse popliedjies (soos Bok van Blerk se "De la Rey", en Steve Hofmeyr se "Pampoen") roep hierdie verlede op. Sulke smeekbede maak hierdie liedjies, in die woorde en idees van die Franse historikus Pierre Nora, les lieux de mémoire (plekke van herinnering) waar die verlede, hede en toekoms saamkom in nuwe verhoudings wat die moderne kollektiewe identiteit beïnvloed. ${ }^{17}$ Ontwikkelende magte van kulturele de-differensiasie lei dikwels tot spanning wanneer plaaslike, tradisionele waardestelsels strydig is met wêreldkulture wat deur massa- (en meer onlangs ook sosiale) media versprei word. In kort, Afrikaners voel die aanslag van die postmoderne wêreld intensief. Dit herinner aan Stuart Hall se opmerkings oor die aanhoudende transformasie van kulturele identiteite. Ons identiteite, wat onderworpe is aan die invloed van "narratiewe oor die verlede", ontwikkel voortdurend en is nie vasgelê in een of ander essensiële waarheid nie. ${ }^{18}$ Soos wat die politieke landskap in Suid-Afrika ontwikkel, en daarmee saam die magsverhoudings, is die reaksies op hierdie ontwikkelinge en die gevolglike aanpassings van

16 Steve Hofmeyr, e-posonderhoude, Augustus 2013 en Mei 2017.

17 Colmeiro, "Nation of Ghosts?", pp. 21-22.

18 S. Hall, "Cultural identity and Diaspora", in J. Rutherford (red.), Identity: Community, Culture, Difference (Londen: Lawrence and Wishart, 1990), p. 225. 
die "self" belangrike faktore van varandering. Dit is moontlik dat Afrikaners, as hulle bedreig voel deur sulke veranderinge, teruggryp na ou narratiewe wat hulle as onbedreigend en "veilig" ervaar, selfs as daardie narratiewe gesetel is in 'n problematiese verlede en weinig aanklank by die idee van 'n reënboognasie vind. Met ander woorde, nostalgie bly 'n integrale strategie om aspekte van Afrikaner-identiteit te behou.

\section{Stereotipes}

In haar studie oor gestileerde uitbeeldings van manlikheid in die tydskrif Die Huisgenoot Tempo idenifiseer Deidre Pretorius sewe tipes: boer, metroman, sportman, retroman, student, werker en rebel. ${ }^{19}$ Hierdie indeling stel identiteit-stereotipes van kontemporêre Afrikaner manlikheid vas, en as 'n mens dit saam met Drewett se werk oor "die verpakking van begeerte" lees, ${ }^{20}$ verskaf die manier waarop kommersiële Afrikaanse sangers hulleself verbeeld - die manier waarop hulle hulle liggame as tekste posisioneer - 'n beginpunt vir verdere ondersoeke oor die moontlike betekenis van hierdie identiteite. Drewett merk ook op dat die manier waarop HG-Tempo vroue in verhouding tot mans uitbeeld, laasgenoemde se "patriargale dividend" uitbrei, en gaan selfs verder deur voor te stel dat die Afrikaanse musiek hoofstroom 'n ruimte geword het waar Afrikaner mans hulle verlore politieke mag kan herwin en weer "helde [kan word] wat die nasie se eer verdedig". ${ }^{21}$

Losvan gender-stereotipes vorm seksualiteit-stereotipes'n sentrale deelvan dieidentiteitsvoorstelling in Afrikaanse popmusiek. Een artikel in HG-Tempo oor gay Afrikaanse sangers het die konserwatiewe aard van die Afrikaanse publiek wat geld op musiek spandeer onthul. ${ }^{22}$ Een gewilde Afrikaanse sanger, bekend vir die (hetero-) seksuele inhoud van sy musiekvideo's, wou nie eers anoniem kommentaar lewer oor sy homoseksualiteit nie, want die risiko dat sy vroue-aanhangers daarvan sou uitvind is te groot. ${ }^{23}$ Dit is ongetwyfeld 'n geldige vrees, maar sy vrese is waarskynlik gebaseer op 'n wyer konserwatiewe gehoor wat nie goed reageer wanneer hulle persepsies van aanvaarbare seksualiteitsnorme uitgedaag word nie. Vroeëre Die Huisgenoot-artikels oor sangers wat openlik oor hulle homoseksualiteit praat, is begroet met sterk anti-gay boodskappe en afkeuring deur lesers. Daar is ook'n konserwatiewe religieuse dogma om in ag te neem. ${ }^{24}$ Homofobie is blykbaar meer algemeen onder ouer Afrikaners, en die generasie wat Fokofpolisiekar en Karen Zoid ondersteun, is, te oordeel na hulle opmerkings op die sosiale media-bladsye van dié kunstenaars, meer verdraagsaam oor kwessies van ras, geslag en seksuele oriëntasie. ${ }^{25}$ Party gay kunstenaars word deur Afrikaanse gehore aanvaar onder spesifieke voorwaardes, gewoonlik deur bepaalde stereotipes te projekteer, soos "buitensporige kostuums en flambojante optredes" ${ }^{26}$ Oor die wêreld heen is anti-gay uitsprake deur popsangers

19 D. Pretorius, “The Visual Representations of Masculinities in Die Huisgenoot Tempo Magazine”, Communicatio, 39:2 (2013), pp. 210-232.

20 "Packaging Desires: Album covers and the presentation of apartheid", in G. Olwage (red.), Composing Apartheid: Music for and Against Apartheid (Johannesburg: Wits University Press, 2008), pp. 115-135.

21 Ibid., pp. 19-20.

22 H. Booyens, “Gay sangers: in of uit die kas?", Die Huisgenoot Tempo 3 (2012), pp. 37-39.

23 Ibid., p. 37. Aan die ander kant is daar baie jonger Afrikaners met erg konserwatiewe menings oor hierdie onderwerpe.

24 Ibid., p. 39, anonieme gay sanger.

25 Ibid.

26 A. Bouwer in H. Booyens, “Gay sangers: in of uit die kas?”, Die Huisgenoot Tempo, 3, 2012, p. 38. 
self egter seldsaam, hoewel die musiekbedryf gebaseer is op tradisionele heteroseksuele waardes. Nog 'n tendens is dat popsangers ook gospelalbums uitreik. Nicholis Louw se Gebed van 'n Sondaar en Gerhard Steyn se Nuwe Krag is onlangse voorbeelde van sekulêre sangers (bekend vir die seksuele ondertoon in hulle werk) wat gospelalbums uitreik het. Die sanger Chris Chameleon het in 2013 Herleef uitgebring, 'n album met rock-weergawes van gospelverse.

Op my vraag hoe hy skynbaar altyd weet wat vir die Afrikaanse musiekmark sal werk, het Steve Hofmeyr die volgende geantwoord:

Dan het ek die belangrikheid van die jonger generasie se deernis vir eye-candy nooit onderskat nie. My vertonings was vroeg reeds oudiovisuele skouspelle. Modes verander, maar ek is maar swak in daardie department. As kunstenaar, selfs kommersiële kunstenaar, is ek sku vir te veel styl oor inhoud. My hele konsert kan voortgaan selfs al is daar 'n kragonderbreking. Gee net die kitaar ... Ek is steeds 'n relatief swak voorspeller van treffers, maar ja, ek weet wat beslis nie sal werk nie. Ek stuur versigtig deur vreemde genres, vreemde klere, vreemde tatoes, vreemde prentjies. Ek hou alles eenvoudig, ook vir myself. Ek maak vanaand se ervaring sterk genoeg dat meeste kliënte my bespreek vir die volgende jaar sonder om te weet wat ek gaan doen volgende jaar. Hulle weet ook reeds dat ek elke jaar vir 25 jaar die konsert verander en iets nuuts saambring - altyd met die regte kwota nostalgie: soos antie Stienie, die Toekas en my films en TV-reekse. ${ }^{27}$

Hierdie vermyding van "vreemde" genres, tatoeërmerke en prente stem ooreen met Pretorius se bevindinge. Hierdie verbeeldings van identiteit-stereotipes dui op 'n definitiewe teësin by Afrikaners om af te wyk van wat hulle sien as tradisioneel. Dit is nie net in die genderrolle aanwesig nie, maar ook in uitbeeldings van ras en politieke sienings. Kunstenaars wat hulself nie in lyn met sulke voorgeskrewe rolle posisioneer nie, of wat nie een van die aanvaarde identiteit-stereotipes aanneem nie, het beperkte toegang tot die hoofkanale van musiekverspreiding en verkoop gevolglik nie naastenby soveel albums nie. So het die waardestelsels wat tydens die apartheid-era opgerig is om Afrikaanse musiekproduksie te reguleer - die begrippe volkseie vs. volksvreemde - bly voortbestaan en floreer nou in die 21ste eeu. Dit beteken egter nie dat Afrikaanse musiek nie ná apartheid gediversifiseer het nie.

Die geleenthede vir nuwe groepe om musiek in nuwe genres te produseer het toegeneem, veral met die stigting van kykNET se musiekkanaal MK in $2005^{28}$ (wat in 2013 van die lug af gehaal is en 'n suiwer aanlyn-platform geword het), en rock-feeste soos Oppikoppi. Bands en kunstenaars soos Bittereinder, Jack Parow en Die Heuwels Fantasties (wat deur van die lede van Fokofpolisiekar gestig is) het in die laaste dekade gefloreer. Om die waarheid te sê, daar het 'n aantal suksesvolle rockgroepe uit die voorstad Bellville noord van Kaapstad gekom wat bande met Fokofpolisiekar het, soos aKing, Van Coke Kartel en nou ook Francois van Coke se solo-loopbaan. Saam geniet hulle aansienlike steun van 'n nuwe generasie jong Afrikaanse rock-aanhangers. 'n Mens sou kon aanvoer dat hulle in 'n sekere opsig 'n soortgelyke etos as die vroeëre Voëlvry beweging het in die sin dat, veral in die geval van Fokofpolisiekar, hulle die Afrikaner middelklas leefstyle van die voorstede waarin hulle grootgeword het, ondermyn. Die musiekvideo van die akoestieke weergawe van Fokopolisiekar se "Hemel op

27 Steve Hofmeyr, e-posonderhoude, Augustus 2013 en Mei 2017.

28 Roggeband, “Tekens van die tye”, Die Huisgenoot Tempo 1 (2012), p. 25. 
die platteland" 29 is byvoorbeeld 'n versameling van ou videomateriaal van die voorstedelike Afrikaner lewe - mense by 'n braai, laerskool rugbywedstryde, skool kadette, kerke, ens., wat skerk kontrasterend staan teenoor die lirieke wat sê "kan iemand dalk 'n god bel en vir hom sê ons het hom nie meer nodig nie?" en "kan jy jou idee van normaal by jou gat opdruk?"30 Soos te verwagte het hulle in 'n post-apartheid Suid-Afrika nie dieselfde politieke invalshoek as Voëlvry nie. Hulle het, in der waarheid, apolities gebly, en die groep het nie bande met enige kontemporêre Afrikaanse protessangers nie. Hulle aanhangers is fanaties en die groep het in slegs twee maande (Maart tot Mei 2017) deur aanlyn crowdfunding'n allemintige R1 077710 vir hulle volgende album ingesamel. ${ }^{31}$

'n Interessante en vindingryke nuwe toevoeging tot die Afrikaanse musiektoneel is die uiters gewilde TV-program Republiek van Zoid Afrika, aangebied deur Karen Zoid, wat oorspronklik'n noemenswaardige impak as outentieke Afrikaanse vroue-rocksanger gehad het met haar treffer "Afrikaners is plesierig", ${ }^{22}$ op haar debuutalbum in 2001, Poles Apart. Die program is in 2014 begin en geniet groot populêre en kritiese aftrek. Dis 'n geselsprogram met meesal Afrikaanse beroemdes as gaste (akteurs, atlete, skrywers, kommediante, ensovoorts), onder wie daar altyd 'n musiekkunstenaar is wat aan die einde van die episode saam met Zoid 'n liedjie doen (dikwels 'n herverwerkte weergawe van een van hulle eie komposisies). Hoewel Zoid veral bekend is as rocksanger, het hierdie samewerkings talle stylgrense oorkruis, met allerlei sangers uit die hede en verlede. Ou Afrikaanse popliedjies is herverwerk in moderne rock, of selfs metal weergawes, terwyl ander meer oorpronklike orkestrale werk tot hulle mees basiese vorms gestroop is. Dit oorbrug die ongemaklike gaping tussen 'pop' en 'artistiek' wat in die verlede soveel wrywing veroorsaak het, met groot sukses. Onmiddelik na elke episode word die liedjie aanlyn op die Apple iTunes platform beskikbaar gemaak en later op 'n versamel-CD en -DVD. 26 liedjies van die afgelope drie seisoene het nommer een status bereik op die Suid-Afrikaanse iTunes trefferlys (gebaseer op musiek wat van iTunes afgelaai is, internasionale liedjies ingesluit), dikwels binne ure na die uitreiking. Geen ander kunstenaar ter wêreld het tot nou toe soveel nommer-een treffers op die plaaslike iTunes-trefferlys gehad nie.

\section{Wie se kultuur?}

As 'n mens die huidige stand van Afrikaanse musiek beskou, is die verhouding tussen kultuur en politiek na my mening van groot belang. Die Afrikaanse kultuur - met Afrikaanse musiek in 'n sentrale posisie - is 'n hoogs gekommersialiseerde kommoditeit. 'n Pertinente vraag is egter: van wie se weergawe van Afrikaanse kultuur word hier gepraat? In die post-sensuur, post-apartheid konteks het nuwe kulturele ruimtes gelei tot identiteitskonsepte oor kultuur- en rasgrense heen. ${ }^{33}$ Selfs die term "Afrikaner" het omstrede geword (of meer omstrede as ooit tevore) en

29 https://www.youtube.com/watch?v=gLPxMGxaosI [besoek 18 April 2017].

30 Translated by author from the original "Kan iemand dalk 'n god bel, en vir hom sê ons het hom nie meer nodig nie?" and "kan jy jou idee van normaal by jou gat opdruk?"

31 https://www.facebook.com/search/top/?q=fokofcrowdfunding [besoek 22 Mei 2017].

32 Dit was die speel met 'n tradiosionele liedjie met dieselfde titel (wat verataal as "Afrikaners is jolly"), en 'n aangrypende sosiale aanmerking op Afrikaners se lewens.

33 R. Davies, Afrikaners in the New South Africa: Identity Politics in a Globalised Economy (Londen: Tauris Academic Studies, 2009), p. 81. 
nie alle wit Afrikaanssprekendes sou hulleself so beskryf nie. ${ }^{34}$ As "Afrikaner" 'n omstrede betekenisse het, geld dit seker ook vir die term "bruin". As populasiegroep verteenwoordig "bruin" Suid-Afrikaners 'n baie diverse en komplekse geskiedenis. Onder apartheid en spesifiek die Wet op Bevolkingsregistrasie van 1950 is alle bruinmense in een groep ingedeel, ondanks baie heterogene elemente. Hierdie groep het daarin geslaag om leefstyle en tradisies te skep wat 'n diverse groep mense saamgebring het in 'n onmiskenbare deel van die "mosaïek van Suid-Afrikaanse samelewing" ${ }^{35}$ Die meeste Afrikaanssprekendes behoort tot dié groep (reeds in 2002 was 58\% van alles Afrikaanssprekendes in Suid-Afria óf bruin óf swart). ${ }^{36}$ Ondanks intense introspeksie deur taalaktiviste regdeur die twintigste eeu, het die vraag of die Afrikaner gemeenskap op ras of taal berus, in die lug bly hang. Afrikaans as 'n taal was 'n sentrale spilpunt in die mobilisering van wit Afrikaners binne 'n leidende politieke entiteit, terwyl bruin Afrikaanssprekendes tegelykertyd uit die proses uitgesluit is. Soos Kennelly toepaslik opmerk het:

If the social identity of the Afrikaner was to be shaped by the acceptance of Afrikaans as a public language on equal footing with English, the creed that the language constitutes the entire people ("die taal is gans die volk") had te be race-blind. ${ }^{37}$

Histories was die kulturele skeiding tussen Afrikaanse moedertaalsprekers langs raslyne 'n baie doelbewuste politieke stap. Hierdie historiese skeiding het gesorg vir aansienlike spanning in die wisselwerking tussen Afrikaanse musiekkunstenaars van verskillende rasse. Dis reeds genoem dat bruin Afrikaanse kunstenaars histories onderverteenwoordig is in die Afrikaanse musiekbedryf ten spyte van hulle fundamentele bydraes tot Afrikaanse musiek.

Dit is vandag nog die geval, hoewel 'n aantal bruin Afrikaanse kunstenaars ook'n wye en diverse aanhang in die post-apartheid konteks gevind het. Die hip-hop-groep Brasse Vannie Kaap (BVK) het gereeld by musiekfeeste in die mid-1990's tot die mid-2000's opgetree, tot die dood van hulle hoofsanger Mr. Fat (Ashley Titus) in 2007. Saam met die vroeëre Prophets of da City (POC) is hulle die toonbeeld van die hip-hop kultuur van die Kaapse Vlakte buite Kaapstad. Die bekende en hoog aangeskrewe DJ Ready D, of Boeta D, was mede-stigter van beide groepe en het 'n groot invloed gehad op die ontwikkeling van plaaslike hip-hop sedert die 1980's. ${ }^{38}$ BVK as 'n groep het baie gedoen om die gaping tussen die bruin Afrikaanse, of soos hulle dit genoem het, "Kaaprikaanse" hip-hop van die Kaap en die wit musiekbedryf te oorbrug. ${ }^{39}$ Nog 'n opmerklike bruin Afrikaanse kunstenaar (en dit is slegs 'n beskrywende term wat, soos wat Afrikaanse musiek ontwikkel, hopelik uitgedien sal raak, en nie bedoel om enige kunstenaar se werk en/of identiteit na net twee dinge - ras en taal - te reduseer nie) is die rapper, motiveringspreker, taalaktivis, skrywer en digter Hemelbesem. Hy het met 'n klompie (onder andere) wit Afrikaanse sangers saamgewerk, van Francois van Coke tot selfs Steve Hofmeyr op 'n herverwerkte weergawe van laasgenoemde se treffer "Pampoen". Dit was skynbaar 'n eienaardige

34 Kennelly, "Beauty in Bastardry? Breytenbach on Afrikaans and the Afrikaners", Portal Journal of Multidisciplinary International Studies, 2:2 (2005), p. 1.

35 D. Martin, "What's in the name 'Coloured'?", in A. Zegeye (red.), Social Identities in the New South Africa, p. 250, vertaal uit die oorspronklike; sien ook Giliomee, Die Afrikaners, p. 629.

36 Giliomee, Die Afrikaners, p. 623.

37 B. Kenelly, "Beauty in Bastardry?", p. 1.

38 I. Roggeband, 50 Stemme, p. 34.

39 Ibid. 
stap, maar ook aangrypend omdat dit'n subteks van kulturele versoening aan die bestaande (wit) nostalgiese en romantiese tema van die oorspronklike liedjie toevoeg. ${ }^{40}$ Hemelbesem is steeds aktief in taalpolitiek en opvoeding en het met die ATKV saamgewerk om jong Afrikaanse talent in die platteland te ontwikkel. ${ }^{41}$ Dit is belangrike werk omdat dit jong Afrikaanssprekendes met verskillende ras-agtergronde oplei in die moontlikhede om in Afrikaans musiek te skryf, terwyl dit aan sommiges 'n wegkomkans uit moeilike huislike omstandighede bied. Verder gee dit lewensvatbare momentum aan die ontwikkeling van inklusiewe Afrikaanse musiek.

Jitsvinger is nog 'n prominente kunstenaar, wat volgens sy webwerf "'n bekroonde Afrikaapse (Afrikaans met'n Kaapse dialek) spreektaal kunstenaar is wat hip-hop, poësie, selfgekomponeerde musiek, teater en storievertelling kombineer." ${ }^{\prime 2}$ Die verwysing na Afrikaaps is belangrik omdat juis die keuse om in Afrikaaps op te tree ruimte skep vir Afrikaanse musiek (en ander artistieke media) wat, ondanks die historiese kragte wat in die ontwikkeling van die dialek 'n rol gespeel het, los staan van die baggasie van wit Afrikaanse taalpolitiek.

Ondanks die bydrae van hierdie kunstenaars bly die hoofstroom media oorweldigend wit, nie net in terme van wie die beste verkope het nie, maar ook hoe dit bemark word. Die topverkoper-CD-reeks Afrikaans is Groot, nou al in die negende uitgawe, het tot vandag toe nie aan 'n enkele bruin Afrikaanse kunstenaar buiten Emo Adams en twee-derdes van die vrouesangtrio Blackbyrd ruimte gebied nie. Die kunstenaars wat optree by groot konserte soos Huisgenoot Skouspel en Afrikaans is Groot sluit selde bruin kunstenaars in - weereens is Emo Adams waarskynlik die mees gereelde gas, terwyl die Bala Broers in die afgelope dekade deel was van 'n paar konserte. Hoewel Afrikaans is Groot in die laaste jare gewilder geword het as Skouspel, is hierdie konserte gesamentlik die grootste konserte in Afrikaans in 'n lang tyd, en hulle sukses is ongetwyfeld te danke aan die feit dat die topverkoper musiekkunstenaars met die mees prominente en openbare profiele daar optree. Vanjaar se konsertreeks in Maart het Steve Hofmeyr, Juanita du Plessis, Karen Zoid, Bobby van Jaarsveld, Karlien van Jaarsveld, Elvis Blue, Laurika Rauch, Jay, Bok van Blerk, Jannie Moolman, Corlea Botha, Dewald Wasserfall, Riana Nel, Lianie May en "'n paar verrassings" ingesluit. ${ }^{43}$ Dit is veelseggend dat Hofmeyr weer ingesluit is ondanks sy omstrede politieke uitsprake, en dat die borge nie onttrek het, soos wat sommige in die verlede gedoen het nie. Een manier waarop die organiseerders verdere omstredenheid kan vermy is om seker te maak dat Hofmeyr hou by 'n voorafbepaalde speellys en nie die ou volkslied, "Die Stem", sing soos wat hy op onlangse kunstefeeste gedoen het nie. Theuns Jordaan is uit die mees onlangse AIG konserte weggelaat weens 'n regsdispuut met die organiseerders. ${ }^{44}$

Terwyl Hofmeyr polities uitgesproke is, is die ander kunstenaars op hierdie lys versigtiger oor wat hulle in die openbaar sê en hulle deel nie almal noodwendig Hofmeyr se politieke siening nie. Interessant genoeg maak omtrent nie een van hulle, Hofmeyr ingesluit, politieke musiek per

40 M. Malan, "Hemelbesem vier taal in komende produksie 'Meeste hip-hoppers wil net stem vir straat wees", Die Burger, 22 Mei 2015.

41 Ibid.

42 http://www.jitsvinger.co.za/ [besoek 17 April 2017].

43 http://www.ticketpros.co.za/portal/web/index.php/event/14311756-bf77-294f-4cf6-5836cf5e3e9e [besoek 14 Maart 2017].

44 http://afrmusieknuus.co.za/2016/10/19/afrikaans-groot-2016-nog-groter/ [besoek 14 Maart 2017]. 
se nie. Die situasie is egter ietwat meer kompleks. Die Afrikaanse pop hoofstroom bied 'n ruimte vir mense wat onwelkom voel in ander openbare ruimtes. Nasionale en provinsiale sportspanne staan onder druk om te transformeer, wat baie wit aanhangers kwaad maak, veral wanneer die spanne nie goed presteer nie. Wanneer hulle wel goed vaar, soos die (getransformeerde) nasionale krieketspan die afgelope tyd, is die transformasiedebat stiller. Dit gaan hier egter nie oor die morsige wêreld van transformasie in sport nie. Daar is in musiek self geen kwotas nie, en as wit Afrikaanse popsangers baie albums verkoop, maak dit sin om hulle almal saam te laat optree. Dit herinner ons aan die ontslape FAK-voorsitter, N.J. van der Merwe, se klagte in 1931 oor die uitreiking van lae kwaliteit boeremusiekplate: hy het gesê sentiment en besigheid gaan nie goed saam nie. Êrens langs die pad kombineer wit Afrikaanse nostalgie en 'n bedryf met 'n geskiedenis van uitsluiting egter, en vorm 'n lens wat die hoofstroom van Afrikaanse musiek tot so 'n mate hervorm dat die ontvangs daarvan uitermate verskil, afhangend van wie daarna luister. Vir party is dit pynlik, terwyl vele blind is vir die pyn wat dit so veroorsaak. Daar is talle staaltjies op sosiale media oor hoeveel tweespalt deur Afrikaanse popmusiek gesaai word.

In 'n onlangse TV-onderhoud het die (wit) Afrikaanse sanger/liedjieskrywer en lid van Die Wasgoedlyn, Riku Lätti, beweer dat hoofstroom Afrikaanse musiek 'n ruimte van rasse-uitsluiting is wat bepaal is deur beperkings wat in die 1950's deur apartheid-ideoloë neergelê is. Die Wasgoedlyn probeer aktief om Afrikaanse musiek terug te vat na'n tyd voordat dit 'gesuiwer' is deur die volksvriendelike masjien. Dit is 'n interessante narratief, aangesien dit die politieke betrokkenheid van Afrikanernasionalistiese kulturele entrepreneurs - waar Anton Hartman uitgesonder word - beskryf as die ontkenning van 'n "natuurlike" bestaansvorm van Afrikaanse musiek en selfs die taal self. Die standaard gebruik van Afrikaans word beskou as 'n nasionalistiese projek, terwyl die Afrikaanse musiekhoofstroom van vandag gesien word as die neweproduk van dekades van politieke inmenging. Veral die Ghoema-musiektoekennings, georganiseer deur 'n radiostasie in Pretoria, veroorsaak woede. Ghoema- of goema-musiek het diep wortels in die Kaapse slawegeskiedenis. 'n Ghoema of goema was 'n soort handtrom waarop 'n bepaalde ritme gespeel is, vergesel deur lirieke wat gespot het met mense in magsposisies. ${ }^{45} \mathrm{Dit}$ is 'n integrale deel van die Kaapse Klopse se musiek en hou spesifiek verband met bruinmense se (dikwels pynlike) erfenis. Die toekennings is egter - gebaseer op stemme van die publiek - byna uitsluitlik wit. Hierdie toeëiening van bruin Afrikaanse musiekkultuur vir 'n wit platform herinner aan hoe kwêla-musiek in die 1950's en 60's onder wit gehore en kunstenaars populêr geraak het. Selfs die spelling van die woord Ghoema het die kritiek van bruin kunstenaars soos Les Javan en Loit Sols uitgelok - hulle beweer die korrekte weergawe is Goema. Volgens hulle dui die feit dat die WAT (Woordeboek vir die Afrikaanse Taal) dit met die foutiewe 'h' spel op die taalpolitiek van die twintigste eeu en die toeëiening van die bruin erfenis. Mede-Wasgoedlyn-lid Churchill Naudé, is 'n rapper wat besonder aktief kwessies van taal en bruin identiteit in sy lirieke aanspreek. Oor die algemeen draai Afrikaanse musiek wat deur bruin kunstenaars geskryf en opgevoer word natuurlik geensins uitsluitlik rondom hierdie kritiese narratief nie. In die huidige manifestasie stel dit egter belangrike vrae oor hoe hoofstroom Afrikaanse musiek vandag pynlike herinneringe oproep van kulturele toeëiening en uitsluiting.

45 D. Martin, Sounding the Cape: Music, Identity and Politics in South Africa, (Somerset-Wes: African Minds, 2012), p. 113. 
'n Uitsondering op hierdie rasseskeiding in post-apartheid Afrikaanse musiek is, weereens, David Kramer, wat verantwoordelik is vir suksesvolle albums en teaterproduksies, waaronder Karoo Kitaar Blues in 2002, waarin hy die platteland vir die verdwynende kitaartradisies van ontmagtigde bruin gemeenskappe deursoek het, en Ghoema in 2006. Albei projekte het die musiek-erfenis van bruin Afrikaanssprekendes ten toon gestel. Die afgelope paar jare het die ATKV merkbaar weggegebreek van hulle Afrikanernasionalistiese wortels en talle besprekings, kompetisies en konserte gereël wat aspekte van bruin Afrikaanse identiteit bevorder. Die ATKV se jaarlikse Rieldans- (die Khoi-San seremoniële dans) kompetisies is baie gewild en die eindrondte, by die Afrikaanse Taalmonument in die Paarl, lok gereeld duisende toeskouers. Die feit dat spesifiek dáár gehou word impliseer 'n gees van inklusiwiteit. Die ATKV hou ook 'n jaarlikse Oesfees op die Solms-Delta-plaas naby Franschhoek. Dié konsert verskil merkwaardig van ander Afrikaanse konserte omdat boer èn plaaswerker ewe welkom is by 'n konsert waar bruin en wit musikante saamwerk in 'n gees wat nêrens anders voorkom nie. Solms-Delta is ook baie progressief wat transformasie betref - die werkers besit 'n gelyke aandeel in die plaas. ${ }^{46}$

Hierdie voorbeelde weerspieël een kant van die spektrum en hoewel daar by Afrikaanse kunstefeeste 'n gewilligheid is om hulle erfenis as eksklusiewe wit kulturele enklawes te verander, bly ras steeds 'n integrale kwessie. Adam Haupt stel die sleutelvraag of diegene wat die toegangsvoorwaardes van die kunstefeeste bepaal, en watter histories benadeelde groepe verwelkom word, dieselfde mense is wat sulke feeste bevonds het vóór die demokratiese oorgang. Hy bevraagteken ook die motiewe waarmee swart Afrikaanssprekendes en/of kunstenaars na sulke feeste genooi word. ${ }^{47}$ Sulke uitruilings is sinneloos as die "ander" slegs genooi word om legitimiteit aan sulke feeste te verleen, maar weinig doen om die materiële omstandighede van gemarginaliseerde mense te verander. ${ }^{48}$ Miskien sal 'n oorsig van 'n paar voorbeelde van optredes by kunstefeeste help om hierdie noodsaaklike vrae te beantwoord.

\section{Omstredenheid en live optredes}

Martin sê dat 'kultuur' selde 'n suiwer oorsprong het, en dat dit eerder die resultaat is van uitruilings en toeëiening. Wanneer kultuur egter gevier word - deur dinge so uiteenlopend as feeste, musiek en selfs kos - gebeur dit op só 'n manier dat verskille uitgelig word en suiwerheid opgeroep word ${ }^{49}$ Dit neem 'n uiters werklike dimensie by Afrikaanse kunstefeeste aan, waar daar dikwels allerlei produkte, wat nie goedgekeur is nie, te koop aangebied word by die vele stalletjies wat verskille uitbuit. T-hemde, byvoorbeeld, wat sê "Praat Afrikaans of hou jou bek" is miskien humoristies bedoel, maar bevat ook'n greintjie aggressie. Terwyl keuses oor die artistieke aanbod van die feeste dikwels onder 'n seleksiepaneel val wat op hoogte is van komplekse taalpolitiek, het die randfeeste ander reëls. Nietemin sou mens ook kon redeneer dat die koop van 'n boereworsrolletjie by 'n Afrikaanse kunstefees nie noodwendig as 'n politieke daad gesien moet word nie. Wat egter wel gedeeltelik waar is, is dat Afrikaanse feeste funksioneer as akute

46 Lisa Isaacs, "No more baas or Klaas at wine estate", 18 Januarie 2017, http://www.iol.co.za/capetimes/news/nomore-baas-or-klaas-at-wine-estate-2097037 [besoek 4 April 2017].

47 A. Haupt, "Is Afrikaans music the biggest 'rassedeurbraakmedium'?", http://www.argief.litnet.co.za/cgi-bin/giga. cgi?cmd=print_article\&news_id=6792\&cause_id=1270 [besoek 17 Julie 2013].

48 Ibid.

49 D. Martin, Sounding the Cape: Music, Identity and Politics in South Africa (Somerset-Wes: African Minds, 2013), pp. 7-8. 
vierings van Afrikaanse kultuur (in wisselende mate, afhangend van die fees), waardeur hulle nuttige fokuspunte word vir die studie van die politieke dinamika en dimensies by live optredes.

In wat sekerlik'n laagtepunt was in trans-kulturele versoening, is 'n insident waar Miriam Makeba by die 1997 Kaktus op die Vlaktes rock-konsert van die KKNK met bierblikkies gegooi is en verbaal aangeval is deur wit lede van die gehoor. Die grootste deel van die skare het duidelik geen waardering vir Makeba se musiekstyl gehad nie, ten spyte daarvan dat sy een van Suid-Afrika se beroemdste internasionale sterre van die twintigste eeu was. ${ }^{50}$ Toe die Afrikaanse sangeres Amanda Strydom later Amandla! geroep het (soos in 1986, toe dit groot opspraak gemaak het), is sy ook met bierblikkies gegooi. ${ }^{51}$ Nog 'n ooggetuie stem saam dat die insident begin het omdat die gehoor nie Makeba se musiek geken het nie, maar voeg by dat die optrede veel langer geduur het as wat beplan is, en dat hulle ongeduldig was om Johnny Clegg en Juluka te hoor. Hy voel ook dat die insident, hoewel betreurenswaardig, deur die media uit proporsie geruk is, maar gee toe dat dit nie sou gebeur het as daar geen alkohol betrokke was nie. Johnny Clegg is met oorgawe ontvang. ${ }^{52}$ Dit is te verwagte, aangesien Clegg vele radiotreffers gehad het op stasies waarna hierdie gehoor geluister het, terwyl Makeba se musiek net hier en daar blootstelling op dieselfde stasies gekry het. Die feit dat die skare Johnny Clegg beter geken het as Miriam Makeba was natuurlik self 'n resultaat van die rassepolitiek wat so deel is van Suid-Afrika se populêre musiekgeskiedenis.

Sedert hulle ontstaan in 2003 het Fokofpolisiekar verdeelde reaksies by die breër Afrikaanse gemeenskap opgeroep - soos baie rock-kunstenaars in konserwatiewe samelewings wêreldwyd - maar 'n insident in 2006 toe die baskitaarspeler, Wynand Myburgh, die woorde "Fok God" op 'n aanhanger se beursie geskryf het, het gelei tot grootskaalse publieke ongelukkigheid..$^{53}$ Gevolglik het kerkgroepe die organiseerders van daardie jaar se KKNK onder druk geplaas om die groep se uitnodiging na die fees te kanseleer. ${ }^{54}$ Die feesraad het daarteen besluit, omdat hulle versigtig was om kunstenaars te sensor en omdat die groep grondwetlik die reg op vryheid van spraak het. Hulle het egter nie die klagtes geïgnoreer nie, en het vergader met kerkverteenwoordigers om 'n toekomstige platform vir grondwetlike riglyne in sulke sake te stig. ${ }^{55}$ Die Nederlandse joernalis Fred de Vries, vergelyk in sy resensie van Annie Klopper se Fokofpolisiekar-biografie die insident met die Sex Pistols:

But "Fok God" has real danger. In the first place this was said in a town, in a country, where the majority of the population is still very Christian in its beliefs. And although the NG Kerk has suffered severe setbacks in its membership since 1994, the rise of the charismatic churches, especially among Afrikaners, is staggering. And their followers don't take blasphemy very well either. So "Fok God" was comparable to the Sex Pistols sneering at that ultimate symbol of Englishness on their second single God Save the Queen ("she ain't no human being") from 1977, which got them banned from the radio, banned from theatres and beaten up by

50 D. Eyal, "Beer cans and boer wars", Mail \& Guardian, 04 April 1997.

51 Ibid.

52 Gerhard Gibbs, elektroniese kommunikasie, 18 Julie 2013.

53 Ibid., p. 122, sien ook J. Nel, "Bobby se ma sit agter bid-brief”, Die Burger, 27 Februarie 2006, p. 3.

54 L. le Roux, "Polisiekarre nie welkom, kla Oudtshoorn", Die Burger, 10 Maart 2006, p. 3.

55 J. Kruger, "Kerkleiers verwelkom 'Waardes vir KKNK”, Die Burger, 24 Maart 2006, p. 3. 
gangs of patriotic thugs. Something similar befell the five members of Fokofpolisiekar, who were banned from venues, received bomb threats and eventually were forced to make a half-hearted apology. ${ }^{56}$

Konserwatiewe godsdienstige oortuigings speel 'n belangrike rol in die manier waarop die Afrikaanse gemeenskap kunstenaars en hulle musiek beoordeel. Baie Christene het gevoel die groep het te ver gegaan en het luidkeels in die openbaar protes aangeteken. Die storie is toevallig geopenbaar deur die ma van die populêre hoofstroom sangers Bobby en Karlien van Jaarsveld. ${ }^{57}$ Sy het ook 'n kettingbrief begin vir Christene om vir die groep te bid. Soos voorheen genoem, is daar baie oor Fokofpolisiekar geskryf - die vernaamste deur Klopper ${ }^{58}$ - en hulle musiek en lirieke sal ongetwyfeld in die toekomstige akademiese diskoers oor populêre Afrikaanse musiek uitgelig word, byna soos met Voëlvry.

In 2009 het nog 'n bierblik-insident plaasgevind by OppiAarde in Potchefstroom, 'n rock-konsert wat deel was van die jaarlikse AARDKLOP kunstefees. Die rap-groep Max Normal TV het, in een van hulle laaste optredes onder dié naam en eerstes as Die Antwoord - wat 'n internasionale internetsensasie en Afrikaanse zefsupergroep ${ }^{59}$ sou word wat wêreldwyd toer - diekonserwatiewe gehoor die harnas in gejaag deur suggestiewe homo-erotiese materiaal op groot skerms te vertoon. Daar is bierblikkies gegooi, en party konsertgangers wou die verhoog bestorm, maar is deur sekuriteitswagte gekeer. ${ }^{60}$ 'n Video van hierdie optrede toon jong, wit Afrikaner mans wat beledigende gebare maak en vloekwoorde skree terwyl die beeldmateriaal op die skerms uit fokus is. ${ }^{61}$ Hoewel hierdie negatiewe reaksies nie deur ras gemotiveer is nie - al die lede van Die Antwoord is wit - was die inhoud van hulle musiek te ekstreem vir die vele konserwatiewe, meesal manlike gehoorlede. Dis ook belangrik om op te merk dat die konsert nie gerig was op die hoofstroom Afrikaanse musiekmark nie. Dit is deur Oppikoppi georganiseer, wat spesialiseer in vertonings wat buite die pop-genre val. Die optredes dié aand het Fokofpolisiekar en Freshlyground ingesluit. ${ }^{62}$ Geen Afrikaanse popsangers was aanwesig nie.

By die Innibos-fees in Nelspruit in Junie 2013 het 21500 mense die konsertterrein verlaat ná die Afrikaanse sanger Juanita du Plessis se optrede, en net voor die gemengde-rassegroep Freshlyground op die verhoog gekom het. 'n Skare van slegs 2000 oorwegend jong feesgangers het oorgebly. Een vroulike aanhanger van Freshlyground, 17 jaar oud en Afrikaans, het die volgende opmerking gedeel:

56 F. de Vries, “Biografie van 'n bende: Fokof, we'll piss where we want”, resensie op Litnet, 14 Junie 2011, http:// www.argief.litnet.co.za/ [besoek 17 Julie 2013].

57 J. Nel, "Bobby se ma sit agter bid-brief”, Die Burger, 27 Februaie 2006, p. 3.

58 MA Uittreksel, 2009; sien ook “'In wrede woede het ek die hand wat beheer gebyt': Die opkoms van Afrikaanse (punk) rockmusiek”, in A.M. Grundlingh en S. Huigen (reds.), Van Volksmoeder tot Fokofpolisiekar: Kritiese Opstelle oor Afrikaanse Herinneringsplekke (Stellenbosch: Sun Media, 2008), pp. 207-217 en Biografie van 'n Bende: Die Storie van Fokofpolisiekar (Kaapstad: Protea, 2011).

59 Zef beteken min of meer werkersklas of common.

60 Die outeur het ook by die konsert opgetree, bevestig deur persoonlike kommunikasie met Tim Rankin, 17 Julie 2013.

61 http://www.yourepeat.com/watch/?v=NAu6eR2KnNM [besoek 17 Julie 2013], sien ook http://www.youares.com/v/fzYdYbHCOuU/die-antwoord-enter-the-ninja-live-rome/ [besoek 17 Julie 2013].

62 http://entertainmentafrica.mobi/music/view/news/23934 [besoek 17 Julie 2013]. 
Ek hoop mense het opgestaan omdat hulle oud is en nie die musiek ken nie, eerder as omdat daar swart lede in die groep is en hulle in Engels sing. ${ }^{63}$

Hoewel dit onmoontlik is om vas te stel presies hoekom soveel van die oorwegend wit gehoor besluit het om voor Freshlyground se optrede te loop, is dit onwaarskynlik dat dit was omdat hulle nie die liedjies geken het nie. Behalwe vir 'n aantal treffers het die groep drie jaar voor dié konsert - saam met die internasionale pop-ster, Shakira - die amptelike lied ("Waka Waka") van die 2010 FIFA Wêreldbeker-sokkertoernooi, wat in Suid-Afrika plaasgevind het, uitgereik. Die liedjie en die groep het uiteraard uitgebreide aandag geniet en die musiekvideo is meer as 'n miljard keer op YouTube gekyk. ${ }^{64}$ 'n Mens moet ook in ag neem dat taal 'n bydraende faktor kon wees.

Hoe kan mens die sterk reaksies wat musiek-optredes by gehoorlede oproep, verstaan? Gehore regoor die wêreld reageer op soortgelyke maniere vir allerlei redes wat verskil van hierdie Suid-Afrikaanse voorbeelde. In die geval van Miriam Makeba en Amanda Strydom was die gehoor se reaksies moontlik rassisties en/of polities van aard, terwyl die reaksie in die geval van Die Antwoord gedeeltelik deur homofobiese sentimente aangevuur is. Freshlyground se optrede by Innibos is meer kompleks. Die konsert het hoofsaaklik uit hoofstroom Afrikaanse kunstenaars bestaan. Die teikengehoor was 'n groep wit Afrikaanssprekendes, 'n groot gedeelte van die mark van die topverkopende Afrikaanse popsterre, wat nie gewoonlik na Freshlyground se musiek sou luister nie. Nietemin dui die vier insidente op 'n teësin by wit Afrikaanse gehore om musiek of kunstenaars te verdra wat hulle as bedreigend, "anders", of albei, interpreteer. Dit blyk dat in hierdie konteks van ontvangs, politiek, ras, godsdiens en seksualiteit ononderhandelbare onderwerpe is. In sulke gevalle funksioneer populêre musiek blykbaar nie as 'n vloeibare medium wat ou grense oorkruis nie. Hierdie dwarsheid is natuurlik nie absoluut nie (Emo Adams was byvoorbeeld in staat om wit konserwatiewe Afrikaanse gehore se guns te wen). 'n Mens moet in ag neem dat al vier insidente by Afrikaanse kunstefeeste gebeur het, wat as ruimtes kan dien vir wat Hauptfleisch die "gebeurtenisifisering" van Afrikaans en Afrikaanse kultuur genoem het. Dit is 'n verwysing na die verhoogde sensitiwiteit vir kulturele uitdrukking tydens erfenisvierings. ${ }^{65}$ Onder sulke omstandighede is Afrikaners minder geneig om hulle kulturele vieringe met die "ander" te deel. Sodoende vorm ou, gevestigde konsepte van ras, geloof en seksualiteit die grense van aanvaarbaarheid in die post-apartheid konteks.

Daar is natuurlik altyd uitsonderings. In 2013 het die KKNK die legendariese swart jazz-sanger en liedjieskrywer Dorothy Masuka genooi om by twee konserte op te tree nadat sy'n toekenning vir lewenslange prestasie by die fees se hoofborg, ABSA Bank, ontvang het. Masuka is die mede-skrywer van die liedjie "Pata Pata", wat 'n enorme treffer vir Miriam Makeba was (wat 'n geteisterde ontvangs by die fees gehad het). Dié keer was die konsert in 'n teater, en Masuka het opgetree saam met Laurika Rauch, Karen Zoid, en Zolani Mahola van Freshlyground (drie maande voor hulle konsert by Innibos). Die konsert is met staande applous toegejuig, en

63 L. Eckhard, “Meeste loop toe 'beste by fees' sing”, Die Beeld, 29 Junie 2013.

64 https://www.youtube.com/watch?v=pRpeEdMmmQ0 [besoek 25 Maart 2015].

65 T. Hauptfleisch, "In Search of the Rainbow: The Little Karoo National Arts Festival and the Search for Cultural Identity in South Africa", South African Theatre Journal, 15 (2001), p. 84; sien ook E. van Heerden, "Liminality, Transformation and Communitas: Afrikaans Identities as Viewed Through the Lens of South African Arts Festivals 1995-2006”, DPhil Tesis, Universiteit Stellenbosch, 2009. 
Masuka het selfs ouer Afrikaner mans uit die gehoor genooi het om die pata pata saam met haar te dans. ${ }^{66}$ Drie maande later was dit ook die vertoning waarmee die Vryfees - 'n Afrikaanse kunstefees in Bloemfontein - geopen is, en ook daar is dit staande toegejuig.

Daar is ook voorbeelde van Afrikaanse kunstenaars wat voor ander bevolkingsgroepe opgetree het by politieke byeenkomste. In 2001 het die outeur opgetree by 'n Erfenisdag-konsert by die Uniegebou in Pretoria. Die Afrikaanse groep Beeskraal het ook dié dag opgetree, wat 'n mengsel van boeremusiek en rock gespeel het deur die konsertina met elektriese kitare te kombineer. Hulle het tradisionele kakieklere en hoede aangehad - 'n beeld wat gelaai is met potensiële negatiewe konnotasies vir die 10 000-plus hoofsaaklik swart ANC-aanhangers. Maar hulle is baie goed ontvang - selfs beter as die meer bekende swart groepe wat ná hulle die verhoog betree het. ${ }^{67}$ Dit impliseer nie dat swart gehore meer verdraagsaam is van die "ander" as wit Afrikaanse gehore nie. Dit dui hoogstens op die situasionele kompleksiteite rondom musiekkonserte op verskillede verhoë in Suid-Afrika.

\section{Wit politiek in post-apartheid Afrikaanse musiek}

My people are dying like flies. Just more violently. - Steve Hofmeyr ${ }^{68}$

'n Aantal Afrikaanse kunstenaars het politieke kwessies in post-apartheid Suid-Afrika aangeroer, maar dis opvallend dat baie van hulle die Afrikaner in die rol van die slagoffer geplaas het. Senekal en Van den Berg gee 'n seldsame blik op sulke Afrikaanse werke - in wat hulle 'n "voorlopige ondersoek" van protesmusiek noem, gebaseer op die ontleding van lirieke. Hulle identifiseer 62 post-apartheid protesliedjies wat tussen 1998 en 2009 uitgereik is ${ }^{69}$ en verdeel hulle in vier hooftemas: misdaad (die realiteit van misdaad en die sielkundige uitwerking daarvan), dienslewering, (waarskynlik wit) Afrikaner-identiteit en protes, en 'n pleidooi om saam te staan. ${ }^{70}$ Onder Afrikaner-identiteit verdeel hulle die tema in subkategorieë, met onder andere kwessies te make met die problematiese plek van die Afrikaner in Suid-Afrika, die nuwe generasie geposisioneer tussen die verlede en toekoms, die veranderende landskap (insluitend Afrikaanse plekname), die mishandeling van die verlede en emigrasie as alternatief. ${ }^{71}$ Stilisties (buiten 'n aantal metal en industriële groepe soos KOBUS en Battery 9), het 'n afdeling van die protessangers, blykbaar'n gedeelte deur Voëlvry gevestig, voortgesit, maar aangesien die konteks so dramaties verander het - Senekal en Van den Berg praat van 'n "her-kontekstualisering" - het

66 Nota: Die outeur het ook by die konsert opgetree; ander media-verslae is te sien by: http://www.sabc. co.za/news/a/e8b1b3004f8495c9aeffee0b5d39e4bb/Dorothy-Masuka-honoured-at-KANA-20130605, http://www.newsday.co.zw/2013/04/02/kknk-honours-dorothy-masuka/,

http://www.youtube.com/watch?v=HsQf94hzExI, [almal besoek 18 Julie 2013].

67 Hier moet ek berus op my eie waarneming, sowel as korrespondensie op 17 Julie 2013 met Charles Schmidt, die sanger en kitaarspeler van Beeskraal.

$68 \mathrm{http}: / /$ stevehofmeyr.co.za/website/steve-se/steve-se-blog-layout [besoek 21 Julie 2013].

69 Vreemd genoeg het hulle ook Johannes Kerkorrel se "Hillbrow" uit 1989 ingesluit, wat strenggesproke nie 'n post-apartheid liedjie was nie. Mens kan (oortuigend) redeneer dat daar teen 1989 'n post-apartheid tema in Afrikaanse musiek ontwikkel het, maar dan sou mens die aansienlike kanon van Afrikaanse protesmusiek van dié spesifieke era moes insluit, soos die werk van kunstenaars soos Koos Kombuis, Die Naaimasjiene, Anton Goosen, ens.

70 “'n Voorlopige verkenning van post-apartheid Afrikaanse protesmusiek", LitNet Akademies, 7:2 (Augustus 2010), pp. 110-118.

71 Ibid. 
die betekenis ook verander. Die breër Suid-Afrikaanse publiek is gevoelig vir Afrikaner oproepe om "saam te staan" of klagtes oor misdaad en die regering se onbekwaamheid, en sien hulle dikwels as die kulturele wendings van Afrikaners wat na regs neig. Aan die ander kant moet ware kuns die samelewing weerspieël. Kunstenaars vra moeilike vrae. Teoreties moet Afrikaanse kunstenaars vry wees om enigeiets wat hulle wil kritiseer, ondersoek, vergewe en goed- of af te keur sonder dat hulle outomaties as apologete van apartheid gesien word. Koos Kombuis het byvoorbeeld op sy 2008 album Bloedrivier nie teruggehou in sy kritiek teenoor die ANC-regering nie. As 'n Afrikaanse protessanger het Kombuis 'n vlekkelose agtergrond, en het miskien meer as enige ander lewende Afrikaanse liedjieskrywer (buiten David Kramer) die reg verdien om "reguit" te praat sonder dat hy as "regs" gebrandmerk word. Op sy nuutste album, Langpad na Lekkersing, neem Kombuis 'n meer positiewe houding oor die Suid-Afrikaanse samelewing in:

Ons het 'n bad president, maar ek kan aan 'n hele paar lande dink wat erger volksleiers het as ons. Daar's plae en oorstromings en aardbewings en burgeroorloë en hier sit ek en jy en rustig gesels in die kombuis en ek weet daar's die bedreiging van misdaad, maar hoe dikwels voel jy dit aan eie lyf? ${ }^{72}$

Hoewel Senekal en Van den Berg se analitiese fokus breed is, sluit hulle lys een liedjie van 'n bruin groep in - Kallitz se "Wat gaan ons maak?". Beteken dit dat bruin Afrikaanse kunstenaars die politiek vermy? Verder stem die lang lys van kunstenaars waarna hulle kyk - d.w.s. die skrywers van protesliedjies - nie ooreen met die hoofstroom van Afrikaanse musiek nie. Hulle sluit wel bekende kunstenaars soos Johannes Kerkorrel en Kombuis in, maar buiten Bok van Blerk en Lianie May is die werklike hoofstroom kunstenaars nie daar nie. Dit wek die vermoede dat hoofstroom Afrikaanse musiek nie eintlik polities van aard is nie. Dit lyk of dit veral jong opkomende en/of meer marginale (in terme van albumverkope) kunstenaars is wat politiek - breedweg omskryf - in hulle liedjies inbring. Mens kan natuurlik redeneer dat die politiek in die kulturele ruimtes waar Afrikaanse musiek uitgevoer word, voorkom, en nie noodwendig in die musiek per se nie. Lydia Goehr het oortuigend geredeneer dat as die "ekstra-musikale" buite beskouing gelaat word, die waarnemer die musikale teks self nie volledig kan begryp nie - die twee hou onlosmaaklik verband. ${ }^{73}$ Alledaagse Afrikaanse popliedjies is dus ook subtiele refleksies van die uiteenlopende maniere waarop Afrikaners hulleself uitdruk en konstrueer as individue en as 'n groep.

Sedert Senekal en Van den Berg se 2010 artikel het 'n reeks openbare debatte oor musiek en Suid-Afrikaanse politiek plaasgevind. 'n Uitstekende voorbeeld hiervan was in 2011, toe die burgerregtegroep Afriforum die destydse president van die ANC-jeugliga, Julius Malema, voor die Gelykheidshof gedaag het weens sy en sy ondersteuners se aanhoudende gesing van die anti-apartheid struggle liedjie, Dubhula I'bunu (Skiet die Boer). Afriforum se argument was dat die sing van hierdie lied op haatspraak neergekom het. Regter Collin Lamont het saamgestem: "Die woorde ondermyn hulle waardigheid, is diskriminerend en skadelik [vir Afrikaners]"74 en het die Wet op die Bevordering van Gelykheid en die Voorkoming van Onbillike Diskriminasie

72 Nadine Theron, "Koos Kombuis dra album aan Kramer op", Netwerk 24, 03/03/2017.

73 "Political Music and the Politics of Music", The Journal of Aesthetics and Art Criticism, 52:1 (Winter, 1994), pp. 99-112.

74 Mail and Guardian, 13 September 2011. 
aangehaal. Tydens die regsaak het Steve Hofmeyr 'n Afrikaanse liedjie, "Ons sal dit oorleef", geskryf, waarin hy gedreig het om die beledigende "K"-woord ${ }^{75}$ te gebruik as die hof in Malema se guns sou oordeel, wat nie gebeur het nie. Die ou struggle-liedjie "Umshini wam" (Bring my my masjiengeweer), wat President Jacob Zuma en sy ondersteuners graag by politieke byeenkomste en buite geregshowe sing, is ewe omstrede.

In Januarie 2012 het ondersteuners van die vermoorde AWB-leier Eugene Terreblanche tydens die hofsaak van twee aangeklaagde mans buite die hof bymekaargekom. Hulle het AWB-uniforms aangehad en liedjies soos "De la Rey" deur luidsprekers uitgeblêr:

The situation threatened to turn nasty when the song "Bobbejaan Klim die Berg" [baboon climbs the mountain] started playing. Tshing residents took offence and retaliated by singing President Jacob Zuma's farvourite song. "Umshini Wam". A clash between the two groups threatened and police stepped in. ${ }^{76}$

Hierdie liedjies verteenwoordig van die mees sigbare en eksplisiete musikale voorbeelde van die botsing van erfenis en identiteitspolitiek in die nuwe Suid-Afrika. Daar is ook ander maniere waarop kunstenaars in die politiek betrokke raak. Op 10 Oktober $2013^{77}$ het 'n groep genaamd Red October optogte en byeenkomste regoor Suid-Afrika en in expat-gemeenskappe oor die wêreld heen georganiseer as 'n protes teen "swart op wit" geweldsmisdaad, soos plaasmoorde op wit Afrikaners, wat hoogs emosionele reaksies onder wit Afrikaners uitlok en selfs aanklagte van volksmoord aanvuur. Sanger/aktivis Sunette Bridges, Bles Bridges se dogter, het in die openbaar haar steun aan die organisasie toegesê (so ook Steve Hofmeyr) en het haar webwerf en ander sosiale media as platforms vir regse Afrikaner politiek gebruik, meesal deur statistieke oor gewelddadige misdaad teen witmense te publiseer. ${ }^{78}$ Haar politieke betrokkenheid het skerp kontrasterende reaksies onder allerlei Afrikaanssprekendes uitgelok en het 'n veel breër impak as haar musiek gehad, ${ }^{79}$ terwyl haar Facebook-bladsy gelei het tot aanklagte van haatspraak en 'n saak voor die Suid-Afrikaanse Menseregtekommissie. ${ }^{80}$ Die tema van geweld op plase het weer in 2014 opgeduik in 'n regsaak toe die (gemengde) hip-hop-groep, Dookoom, by die kommissie aangekla is van haatspraak na hulle 'n omstrede video, "Laarnie jou poes", uitgereik het. ${ }^{81}$ Daar is aangevoer dat die liedjie en gepaardgaande video 'n oproep tot geweld was, aangesien dit bruin plaaswerkers getoon het wat 'n plaas wat aan witmense behoort, afbrand. ${ }^{82}$ In lynregte opposisie teen die konsep van die "Afrikaner as slagoffer" het Dookoom die plaaskonteks gebruik om die historiese ras- en ekonomiese onderdrukking van bruin plaaswerkers deur wit grondbesitters te verbeeld - 'n politieke kwessie wat weer in 2013 in die Wes-Kaapse provinsiale politiek opgevlam

75 Verwys na die hoogs beledigende woord "kaffer".

76 O. Mooki, "Battle of the songs", 31 Januarie 2012, beskikbaar by http://www.iol.co.za/the-star/ [besoek 29 Mei 2012].

77 Dit is weer in Oktober 2014 herhaal.

78 http://sunettebridges.co.za/ [besoek 16 Julie 2013].

79 http://www.channel24.co.za/News/Local/Sunette-denies-racism-claims-20101029 [besoek 12 Augustus 2013]; http://www.news24.com/Tags/People/sunette_bridges [besoek 12 Augustus 2013].

80 http://www.sahrc.org.za/home/index.php?ipkArticleID=330 [besoek 20 Mei 2015].

81 http://www.timeslive.co.za/politics/2014/10/15/afriforum-submits-hate-speech-complaint-against-rap-groupdookoom [besoek 14 Januarie 2015].

82 https://www.youtube.com/watch?v=kmgpDostEqk [besoek 26 Maart 2015]. 
het. ${ }^{83}$ Die groep het ontken dat hulle hoegenaamd bedoel het om geweld op te roep, en het gesê die video was slegs bedoel om debatte oor hierdie problematiese temas aan te wakker. ${ }^{84}$ Dit het in elk geval diep vyandigheid tussen rasse en teenstrydige aansprake op onderdrukking deur "die ander" ras uitgelig. Pogings om die video van YouTube te verwyder het nie geslaag nie.

In nog 'n effens bisarre saak in 2014 het die Afrikaanse aktivis, Dan Roodt, versoek dat 'n tussentydse hofbevel (wat later omgekeer is) die kommediant en buikspreker Konrad Koch (en sy buikspreekpop Chester Missing) keer om Steve Hofmeyr op sosiale media lastig te val nadat laasgenoemde getwiet het dat volgens hom, "swartes die argitekte van apartheid was". Die gevolge van die twiet en die daaropvolgende regsgeding het 'n veel wyer impak gehad as net 'n onderonsie tussen 'n pop en 'n sanger. Pick n Pay en Jaguar Land Rover Suid-Afrika, borge van die Afrikaans is Groot-konserte, het hulle steun onttrek omdat Hofmeyr steeds sou optree. ${ }^{85}$ In 'n reaksie hierop het die beroulose Hofmeyr getwiet:

\section{Boycotts won't change my observation that Africa never did \& still doesn't inspire integration \#ArchitectsOfApartheid. ${ }^{86}$}

Hierdie twee gevalle onderstreep die kompleksiteit van aggressiewe rassepolitiek in populêre Afrikaanse musiek sedert die einde van apartheid en daag die sosiale en wetlike grense van artistieke uitdrukking uit, asook die sensuur van artistieke uitdrukking en die wetgewing van protes. Hulle dui ook op stygende spanning in 'n kultureel pluralistiese samelewing. Ook in 2014 het Hofmeyr by die Innibos fees in Nelspruit die skare van $45000^{87}$ gelei in 'n impromptu uitvoering van "Die Stem" - die volkslied van voor 1994. Die reaksie van die gehoor was hoogs emosioneel en die meeste mense in die skare het saamgesing. ${ }^{88}$ Dit het die organiseerders van die fees in 'n moeilike posisie geplaas aangesien hulle nie wou hê dat die fees - wat baie gewild is onder wit Afrikaners - 'n gepolitiseerde platform word nie. In reaksie hierop het die bestuur van Innibos Hofmeyr nie teruggenooi na die fees in 2015 nie, ${ }^{89}$ 'n besluit wat die KKNK ook in daardie jaar geneem het. ${ }^{90}$ Die uitval op sosiale medial ten gunste van Hofmeyer stel voor dat die besluit deur die fees organiseerders nie die feeste gevrywaar het om 'n politieke platform te word nie, ten minste nie vir die 2015-seisoen nie. Hofmeyr het "Die Stem" ook op sy mees onlangse album ingesluit, wat baie radiostasies gevolglik weier om te speel. ${ }^{91}$

Hoewel Hofmeyr se naam byna altyd opkom as Afrikaner politiek en musiek oorvleuel, moet sy omstrede aksies nie die bepalende faktor wees wanneer mens die politieke klimaat van Afrikaanse popmusiek in die 21 ste eeu beoordeel nie. Hoewel hy al sedert die laat 1980's 'n

83 http://www.citypress.co.za/entertainment/dookoom-angry [besoek 26 Maart 2015].

84 http://www.bdlive.co.za/national/2014/11/27/steve-hofmeyr-0-chester-missing-1 [besoek 26 Maart 2015].

85 http://www.channel24.co.za/music/news/land-rover-and-pick-n-pay-pull-concert-sponsorship-after-stevehofmeyrs-racist-tweet-20150317 [besoek 13 Maart 2017].

$86 \mathrm{http} / /$ www.channel24.co.za/music/news/land-rover-and-pick-n-pay-pull-concert-sponsorship-after-stevehofmeyrs-racist-tweet-20150317 [besoek 13 Maart 2017].

87 http://www.channel24.co.za/Music/News/Hofmeyr-urges-fans-to-continue-singing-Die-Stem-20140708 [besoek 25 Maart 2015].

88 https://www.youtube.com/watch?v=F2wDNYVe7uo [besoek30 Maart 2015].

$89 \mathrm{http} / / /$ lowvelder.co.za/247693/hewige-reaksie-na-innibos-steve-nie-weer-nooi/ [besoek 30 Maart 2015].

90 http://www.netwerk24.com/nuus/2015-01-24-kknk-sou-steve-hofmeyr-nie-toelaat [besoek 30 Maart 2015].

91 http://www.timeslive.co.za/entertainment/2014/08/27/steve-hofmeyr-to-include-die-stem-on-new-album [besoek 26 Maart 2015]. 
groot Afrikaanse musiekkunstenaar is, het sy politieke posisie eers relatief laat in sy loopbaan regtig begin uitkom. Sy naam roep egter 'n aantal dinge op: vir sommige is hy 'n oorblyfsel van apartheid, 'n saaier van rassehaat en 'n verleentheid vir Afrikaners. Vele ander neem sy boodskap baie anders op, wat mens dwing om toe te gee dat hy meer as bloot'n ekstreme regse randgroep verteenwoordig. Dit is veelseggend dat een manier om die grootte van die huidige groep polities regse Afrikaners te meet is om Hofmeyer se aanhang te bekyk. Wanneer 45000 wit Afrikaners “Die Stem" sing, is dit nie meer 'n randverskynsel nie. Hy het meer as 225000 Twitter volgelinge (hoewel dit nie noodwendig 'n akkurate aanduiding van sy ondersteuning is nie) en meer as 400000 ondersteuners op sy Facebook-bladsy (miskien 'n beter aanduiding). Terloops, dit is die hoogste syfers van enige hoofstroom Afrikaanse sanger. Daar is eenvoudig geen presedent in die geskiedenis van Afrikaanse musiek vir wat Hofmeyr vergestalt nie. Terwyl dit belangrik is om nie sy invloed te oordryf nie, is dit net so belangrik om dit nie te onderskat nie en is dit nodig om te probeer verduidelik hoe dit oor die afgelope paar jaar ontwikkel het:

Dinge verander wel. Jy word ouer. Sien ander dinge raak. Ek is 'n effe van 'n
laatslaper by die politiek, maar teen 2006 was dit vir my duidelik dat my eie stam
slagoffers geword het van my ywerige JA stem in die vroeg 90 's (toe ek bykans
geen politieke brein gehad het nie.) Ek misbruik ironies steeds baie min van my
100 minute konsert vir my politieke veldtogte. Maar daardie uur bly 'n kulturele en
populistiese een: bietjies Engels, baie Afrikaans, baie nostalgie, wikkelnommers en
ballades... By die afwesigheid van getalle partypolitiek, is ek lewende bewyse (en
dra ek eerstehandse kennis) van hoe sterk en baie ons nog is, hoe ons ooreenkom
oor eenvoudige regte en verwagtinge - daarom my hubris. ${ }^{92}$

Dit is veelseggend. Baie Afrikaners is gefrustreerd oor dieselfde kwessies, en stem saam met Hofmeyr se openbare uitsprake wat met hulle te make het. Sy konserte funksioneer as ruimtes waar "Afrikaanse mense kan sê wat hulle dink". Hoewel hoogs omstrede, verteenwoordig dit die breër opkomende tema van die "Afrikaner as slagoffer", wat 'n aantal vergelykings met die eerste vier dekades van die twintigste eeu toon, waaruit die etniese nasionalisme gekom het wat tot formele apartheid ontwikkel het. Deur Afrikaners as slagoffers te posisioneer, vind 'n komplekse transformasie plaas waarin die verlede nie meer 'n moeilike herinnering is wat met apartheid verband hou nie, maar meer'n bron van legitimiteit. Dié tema kom dikwels voor in post-apartheid Afrikaanse popliedjies, waarvan "De la Rey" die mees voor die hand liggende voorbeeld is. Die liedjie het 'n sterk onderstroom in die Afrikaner-samelewing sigbaar gemaak - daar's 'n rede vir die liedjie se groot sukses - en nie almal van hulle was/is onproblematies nie. ${ }^{93}$ Hofmeyr gee 'n verklaring vir hierdie politieke herposisionering as "slagoffer" op sy blog:

State-induced poverty on any minority is genocide and my little tribe is dying at the hands of other people and my government is marginalising my culture by undermining mother tongue education and keeping us out of the workforce with skin based policies. ${ }^{94}$

92 Hofmeyr, e-posonderhoude met outeur, Augustus 2013 en Mei 2017.

93 Stel jou voor hoe Emo Adams moet voel as hy 'n verhoog betree om voor 'n wit gehoor op te tree wat pas met hulle hande op hulle harte "De la Rey" uit volle bors gesing het.

94 http://stevehofmeyr.co.za/website/steve-se/steve-se-blog-layout [besoek 21 Julie 2013]. 
Politiek word deel van die pop-ervaring, vermaak word vermeng met 'n behoefte om sosio-politieke kwessies te verwoord, en mak allerlei foutlyne onder Afrikaners sigbaar. Hofmeyr het meer onlangs 'n veldtog gevoer om Afrikaner monumente te beskerm nadat 'n aantal van hulle gevandaliseer is. ${ }^{95}$ Op die vraag of sy gehore se politieke sienswyses divers is, en of hy popmusiek as 'n geldige medium om politieke boodskappe oor te dra, sien, sê hy:

Uiteenlopend, nee. Maar uitbundige behoefte om te verwoord wat jy nêrens elders mag nie, beslis. Die lied "Ons sal dit oorleef", of "Die Stem" is net 4 minute uit my I00-minuut konsert. Maar my roetine ligte-aan-vra-wat-jy-wil-sessies elke aand, kan ek sien dat baie my konsert gebruik as sametrek vir meer as popmusiek en note en akkoorde. My gehore is baie breed, families, veilig, kultureel-nostalgies en oorwegend behoudend. Omdat ek nie 'n party het, of elektolraat of mandaat nie, is ek rerig vry om te sê wat ek wil en ek doen. Ek is gelukkig dat my mense my verstaan en dat die lamsakkigheid van my regering ongelukkig my saak versterk, elke aand. Ek bereik al vir 25 jaar I 000+ mense vier keer per week. Dis sommer baie canvassing vir een Suid-Afrikaner. Sosiale media daarby gereken kan jy sien hoekom liberale media enigiets sal doen om ons te ondermyn. Jou veronderstelling is reg. Ek kry meer reg om subtiel te wees. Daarom is my konsert nie uitsluitlik 'n politieke ene nie. Dis rou vermaak tussen mense waarby min gesê hoef te word. En 25 CD's is baie musiek om deur te kom!

Vroeg in 2015 het Hofmeyr aangekondig dat hy amptelik die politiek sou betree as hy 'n miljoen ondersteuners kon kry. Gevolglik is daar 'n Facebook-groep gestig om dié doel te bereik. Met die laaste telling was daar meer as 190000 lede. ${ }^{96}$ Dit is egter moeilik om die daadwerklike aantal te bepaal, aangesien heelwat mense, waaronder ander Afrikaanse kunstenaars, ${ }^{97}$ sonder hulle medewete by die groep gevoeg is, en gevolglike versoeke om hulle te verwyder vyandig begroet is. Dit is nie net Hofmeyr se aanlynaanhangers wat politieke aanvalle kan doen nie. In Februarie 2017 is Francois van Coke, hoofsanger van Fokofpolisiekar en Van Coke Kartel en nou ook 'n suksesvolle solokunstenaar, aanlyn swaar daarvoor gekritiseer dat hy in Port Elizabeth op dieselfde konsert as Hofmeyr opgetree het. Hoewel Van Coke in die openbaar altyd apolities gebly het, is hy daarvan beskuldig dat hy rassisme ondersteun deur nie van die konsert te onttrek nie. Die situasie is vererger toe Hofmeyr 'n foto van hulle twee saam (geneem in die verbygang by die gastehuis waar albei gebly het) op sy webwerf geplaas het. Amper geen Afrikaanse kunstenaar het nog van 'n konsert waar Hofmeyr ook optree onttrek nie. Een uitsondering was weke vantevore, toe David Kramer geweier het om by 'n konsert op 'n wynplaas in Stellenbosch op te tree (waar hy 'n toekenning vir lewenslange bydrae sou ontvang) toe hy uitvind dat Hofmeyr ook sou optree. Dit wys duidelik net hoe onseker die politiek van Afrikaanse musiek kan wees: die keuse is deur sommige toegejuig, maar deur vele ander swaar gekritiseer, tot so 'n mate dat Kramer sy Facebook-bladsy moes toemaak. Dit bevestig ook die feit dat ons op die oomblik een van die mees akute politieke fases in die geskiedenis van Afrikaanse musiek meemaak, met duidelike foutlyne wat selfs die uitvoer van apolitiese Afrikaanse rock onmoontlik maak. Bowendien, selfs al word Afrikaanse musiek hipoteties inklusief en die geskiedenis van

95 "Steve Hofmeyr, Sunette Bridges defend Paul Kruger statue", beskikbaar by http://ewn.co.za/2015/04/08/Crowdgathers-in-defence-of-the-church-square-statue [besoek 20 Mei 2015].

96 https://www.facebook.com/groups/1409646456011242/?fref=ts [besoek 13 Maart 2017].

97 Veral Valiant Swart het taamlik bisarre dreigemente en beskuldigings ontvang. 
uitsluiting van die grootste deel van sy sprekers word gekorrigeer, sal daar ongetwyfeld dié wees wat hulleself daarvan distansieer en eksklusiewe ruimtes skep waar hulle vermaak kan word sonder om dié ruimte te deel met mense van ander rasse. En solank as wat dié ruimtes bestaan, sal daar kunstenaars wees wat daarvoor voorsiening maak.

'n Mens wonder of die Afrikaanse musiek hoofstroom nie daadwerklik meer problematies is as die bloot insidentele overte politieke kunstenaars wat hulle politiese sienswyses openbaar bekend maak nie. Dit is grotendeels eksklusief, dit projekteer wit bevoorregting en vermy meesal konstruktiewe dialoog oor ontwikkeling en insluiting. Die toeëiening van bruin Afrikaanse kulturele dinge vir 'n byna eksklusiewe wit mark (soos die Ghoema-toekennings) is ook problematies. Dit is ook meer direk verantwoordelik vir die instandhouding van magstrukture wat in die apartheidsverlede gewortel is as die enkele sanger wat met 'n akoestiese kitaar soos Voëlvry wil wees, maar op die een of ander manier nie verstaan dat dit in die huidige konteks onmoontlik is nie. 
Die bedoeling met hierdie boek was nooit om 'n volledige diskografie of ensiklopedie van opgeneemde populêre Afrikaanse musiek te wees nie. Daarom is dit heeltemal moontlik dat sommige lesers gefrustreerd sal wees deur die weglating van sekere Afrikaanse sangers en kunstenaars. Wat wel die bedoeling was, was om ooglopende temas in die geskiedenis van opgeneemde Afrikaanse musiek en die verhouding daarvan tot die evolusie van die samelewing waaruit dit voortgespuit het, uit te lig. Dit is opvallend dat van die eerste oomblikke in 1900 toe Van den Berg, Spieksma, Brückner en Cornelli hulle onderskeie weergawes van musiek vir mense wat Afrikaans praat opgeneem het, is die motief van wit Afrikanernasieskap so diep daarin vasgelê. Dieselfde geld vir die eerste opnames wat in Afrikaans was, nie noodwendig weens die inhoud daarvan nie, maar eerder weens die mense wie dit opgeneem het. Die relevansie van mense soos J.J. Smith en Annie Visser spesifiek, was hulle direkte verband met die Afrikaanse taalpolitiek van die eerste twee dekades van die twintigste eeu. Sulke uitlatings van sterk affiliasie met die Afrikaanse taal, wat in daardie begindae nog in 'n vroeë ontwikkelingsfase was, spreek boekdele. Wat ook belangrik is, is hoe Afrikaanse kulturele efemera, soos die bewoording van advertensies, die ongemaklikheid weergegee het wat tussen wit Engelse en Afrikaanssprekendes bestaan het. As 'n mens in ag neem watter Afrikaanssprekendes in daardie era toegang tot opnamefasiliteite gehad het, was diegene wat in Londen musiek opgeneem het meesal wit Afrikaanse beurshouers, terwyl latere opnames wat Dillnutt in 1912 in Kaapstad en Johannesburg gemaak het van meer gevestigde kore of bekende digters en storievertellers was. As 'n mens net op grond van inhoud sou bepaal wat hierdie opnames reflekteer het, sal dit 'n mengsel wees van liturgiese liedere en meer alledaagse dinge wat met die ontspanningsaktiwiteite van wit Afrikaners te doen het wat so hier en daar 'n neerhalende rasopmerking ingesluit het 
wat die rashiërargie van daardie tyd vasgevang het. Dit wys ook die geïsoleerde karakter van die Afrikaanse musiekbedryf, wat so problematies in die post-apartheidsera is, wie se historiese wortels terugdateer na die eerste opnames van populêre Afrikaanse musiek.

Wat die ontwikkeling van radio in Suid-Afrika betref, het die Eerste Wêreldoorlog 'n fase van stagnering ingelui, maar van die vroeë 1920's af is daar al hoe meer uitgesaai. Die plaaslike musiekopnamebedryf aan die ander kant was sluimerend tot die middel van die dekade, en het eers begin momentum kry in 1930. Albei het vinnig gegroei teen die agtergrond van geweldige sosiale omwenteling in die volgende dekade. Om oor die Afrikaner-samelewing van die 1930's te skryf bring vele uitdagings omdat dit 'n besondere besige periode in die Suid-Afrikaanse geskiedenis was. Die sosiaal-ekonomiese en politieke verskuiwings van daardie tyd het verreikende gevolge gehad. Op papier was Afrikaans gelyk aan Engels sedert 1925 (en by implikasie was wit Afrikaanssprekendes gelyk aan Engelssprekendes) hoewel daar in praktyk geen gelyke toegang was tot kapitaal, opvoeding en bestuursposisies vir Afrikaners by semi-staatsinstellings soos die Suid-Afrikaanse Spoorweë nie. Dit was gedeeltelik uit hierdie onvergenoegdheid waar die Afrikanerkultuurorganisasies hulle energie geput het. Wit Suid-Afrikaners in die algemeen, maar spesifiek wit Afrikaners, was baie klassensitief aangesien arm witmense moontlik oor die kleurgrens kon val en dus die politieke integriteit van die wit stem in gevaar kon stel. As gevolg daarvan was die kulturele manifestering van die Afrikaner werkersklas problematies op politieke vlak. Die FAK het bevoorbeeld onmiddellik iets opgetel toe die Columbia-platemaatskappy sy soektog na musiek met 'n "plaaslike geur" aangekondig het. Die opnames van vroeë vastrap-boereorkeste soos Die Vyf Vastrappers en Die Voortrekker Danskwartet se musiek het skaars begin voordat die FAK se base daaroor begin kla het. Dit was nie net oor musieksmaak nie; dit was 'n vernedering (en 'n werklike politieke bekommernis) vir Afrikaners wat die Afrikanerkultuur wou oplig tot op die vlak van hulle Europese eweknieë en wou wegbeweeg van plaaslike, organiese ontwikkelde populêre kultuur wat aan die ontwikkel was aan die verkeerde kant van die snelgroeiende stede. Die opkoms van kultuurpolitiek wat beheer is deur ultra-nasionalistiese "organisasiemans" het baie bygedra tot die totstandkoming van 'n nuwe etniese nasionalistiese identiteit gebaseer op 'n Afrikaner volksmitologie. In wese was dit 'n poging om 'n sentrifugale momentum op te bou wat 'n heterogene wit Afrikanerbevolking kon homogeniseer. Wat ook belangrik is, is die feit dat hierdie nuwe Afrikanernasionalisme nie die enigste beskikbare ideologie vir Afrikaners was nie. Nasionaliste moes meeding met sosialistiese elemente onder Afrikaanse werkers, asook met Suid-Afrikaniste wat nie die idee dat wit Afrikaners 'n politieke identiteit apart van wit Engelssprekendes moet onwikkel, gesteun het nie.

Afrikaanse liedjies wat nie goedgekeur is op grond van die model van volkseie vs. volksvreemde nie is nie by die eerste FAK Volksangbundel van 1937 ingesluit nie. Dit het afgespeel teen die agtergrond van die eerste golf van kommersiële Afrikaanse musiek wat in 1930 begin en groot sukses behaal het. Die musiek van Chris Blignaut en David de Lange - die groot name in Afrikaanse musiek in die 1930's - is geheel en al uit die bundel weggelaat. Dit het tot 'n mate in hulle gesigte opgeblaas tydens die Eeufeestrek in 1938 toe die kulturele elite gefrustreerd geraak het met die Afrikaners wat nie die volkswysies geken het nie, maar treffers soos De Lange se "Suikerbossie" goed geken het. Dit het die harde werklikheid van die kommersiële musiekmark reflekteer - ideologie het tweede viool gespeel teenoor wins, en dit is bevestig deur die hoof van die FAK, N.J. van der Merwe, in 'n klaagstuk reeds in 1931. Dit is maklik om die rol van 
die FAK en ander geaffillieerde kuturele agente se invloed op Afrikaanse popkultuur te oorskat. Ten beste was hulle impak in die 1930's beperk. Hulle spesifieke impak op populêre Afrikaanse musiek is moeilik om te bepaal, maar die aanduidings (as 'n mens kyk na David de Lange se verkoopsyfers, byvoorbeeld) is dat dit waarskynlik minimaal was ten spyte van hulle beste pogings. Die Volksangbundel is wyd in skole en musiekklasse versprei, maar dit was dikwels in kontras met die gewilde liedjies wat op Afrikaanse plate uitgereik is. Dit is ook 'n tasbare aanwyser as 'n mens probeer bepaal hoeveel Afrikaners in daardie tyd 'gekultiveerd' was.

'n Belangrike toevoeging tot die Afrikaanse musiekbedryf in daardie tyd was die stigting van die SAUK in 1936 en die geboorte van die Afrikaanse diens in 1937. Die verskillende soorte boeremusiek wat in hierdie era te voorskyn gekom het getuig van die heterogene aard van die wit Afrikanergemeenskap van daardie tyd. Sekere boereorkeste, soos die Stellenbosch Boereorkes, was openlike propagandamasjiene vir die nasionalistiese saak en was stilisties anders as die ander, het anders opgetree en het waarskylik ideologies verskil van die vroeë, werkersklas boereorkeste van mense soos Faan Harris en was 'n teenpool van David de Lange se liedjies oor dronkenskap en ontug. Die SAUK se weiering om De Lange se musiek uit te saai is ook opmerklik. Hendrik Susan se groep was meer modern, professioneel en gereed vir die eise van gereelde regstreekse radio-uitsendings. Vir hulle was die hoofmotivering ekonomies en die politiek het pragmaties gebly. Musikaal was Susan instrumenteel in die ontwikkeling van ligte Afrikanse musiek wat die base van die FAK Musiekkomitee asook die van die SAUK met die praktiese probleem gelaat het om die kulturele waarde daarvan te bepaal. Hier was 'n moderne genre wat internasionale tendense gereflekteer het, aan die een kant het dit geresoneer met Afrikaner ambisies om by die res van die wêreld kers vas te hou, maar aan die ander kant het dit iets vreemds en bedreigends verteenwoordig. As die kulturele entrepreneurs nie so gefikseer was op Afrikanerkultuur nie, sou hulle nie op 'n twee-dekades-lange sending gegaan het om te probeer om die verskille tussen tradisionele boeremusiek en ligte Afrikaanse musiek uit te wys nie. Hulle erkenning van die vastrap-boeremusiek van die 1930's, waarop hulle eens neergesien het, as regmatige Afrikaanse volksmusiek teen die laat 1940's was 'n aanduiding dat dit teen daardie tyd nie meer as 'n bedreiging beskou is nie. 'n Mens kan selfs verder spekuleer dat dit 'n aanduiding kon gewees het van 'n aanvaarbare vlak van kulturele homogenie wat bereik is, wat gemanifesteer het as werklike politieke mag en dat klassespanning onder wit Afrikaners effens minder was. Hulle akademiese werke, seminare en artikels oor kommersiële Afrikaanse musiek van die 1940's af is die vroegste werke oor die onderwerp en plaas die oorspronklike geskiedskrywe daarvan binne-in die dominante narratief van Afrikanernasionalisme. Anton Hartman se stelling in 1955 dat bruin musikante histories die primêre opvoerders van boeremusiek was (hy noem dit "hotnotsmusiek"), maar dat dit in wese die musiek van wit Afrikaners is aangesien dit hulle dansmusiek was wat hulle vir die bruin werkers gegee het om te speel, is 'n goeie voorbeeld van hoe ideologie voorkeur geniet het bo die waarheid.

Terug in 1939 het die uitbreek van die oorlog groot sosio-politieke verandering in Suid-Afrika ingelui. Daar is al baie geskryf oor die politieke uitval tussen Hertzog en Smuts oor Suid-Afrika se deelname aan die Britte se kant. Dit is relevant hier omdat dit die dinamika by die SAUK verander het. Die feit dat die SAUK politieke neutraliteit laat vaar het ten gunste van die oorlog het sommige Afrikanernasionalistiese personeellede warm onder die kraag gemaak. Dit het ook gelei tot verhoogde spanning tussen die SAUK en die FAK, wat reeds met die Eeufeestrek die vorige jaar begin het toe die SAUK geweier het om politieke toesprake deur Afrikanernasionaliste 
uit te saai juis op grond van neutraliteit. Tydens die oorlog het Hendrik Susan opdrag gekry dat die SAUK nie meer enige optredes van musiek uit die FAK se Volksangbundel regstreeks sou uitsaai nie. Gegewe die gevaar wat Afrikaners se nasionalistiese organisasies tydens die oorlog in die gesig gestaar het, het hierdie opdrag sin gemaak. Susan is selfs kortliks ondervra omdat hy gereeld die verpligte "God Save the King" opgevolg het met "Kent gij dat volk?" by sy konserte. Ten spyte van die spanning by die SAUK was daar ironies genoeg 'n geleidelike toename in Afrikaanse personeel omdat Engelssprekendes vrywilliglik in die oorlog gaan veg het. Aan die platebedryfkant is die verskeping van opgeneemde meesterkopieë sodanig in die wiele gery dat dit amper onmoontlik was om nuwe musiek uit te reik.

Die primêre politieke verskuiwing ná die oorlog was die Nasionle Party se sege by die stembus in 1948, wat die era van apartheid ingelui het. Nodeloos om te sê, soos in alle sektore van die Suid-Afrikaanse samelewing, sou dit die plaaslike musiekbedryf op verskeie maniere raak oor die volgende paar dekades. Dit het egter nie die vinnige groei van die bedryf in die wiele gery nie. Die groeiende Afrikaner middelklas weens die raskapitalisme van apartheid het 'n groeiende mark vir kommersiële Afrikaanse musiek beteken. Die opening van Gallo se plaaslike plate-aanleg in 1949 het nuwe lewe in die plaaslike bedryf geplaas ná die vertragings wat die oorlog veroorsaak het en het gelei tot 'n vermenigvulgiging van plaaslike opnames, wat ook Afrikaanse opnames ingesluit het. Met die samewerking van die stigting van die SAUK se kommersiële radiostasie, Springbok Radio, in 1950, het hierdie plate baie lugtyd gekry en talle het goeie verkope getoon - en niemand het meer verkoop as Nico Carstens nie. Carstens en Anton de Waal se vennootskap as liedjieskrywers, wat waarskynlik steeds die mees kommersieël suksesvolle vennootskap in die geskiedenis van Afrikaanse musiek is, het in 1951 begin en het op die golf gery van wit Afrikaners se nuutgevonde geldelike sukses. Hoewel Carstens se artistieke talent veel verder gestrek het as net boeremusiek en hy die genre dikwels sterk veroordeel het, was dit sy boeremusiekalbums wat in hierdie era die beste verkoop het. 'n Mens kan maar net wonder of Carstens nie dalk vasgevang was in sy gewildheid onder wit Afrikaners en dus onderhewig aan hulle smakk (wat baie beperkend kon wees) was nie. Boeremusiek was baie gewild, terwyl jazz (een van sy groot liefdes) beperkte aanhang geniet het.

Die 1950's en '60's was natuurlik 'n tydperk van optimisme vir wit Afrikaners, wie die primêre begunstigdes van apartheid was. Carstens se bloeitydperk het daarmee saamgeval, maar hoewel sy plaatomslae dikwels Afrikanernasionalistiese-simbole soos ossewaens en so aan opgehad het, was daar tekens dat hy nie heeltemal ingekoop het in die dominante narratief van rasseskeiding nie. Hy het diep waardering gehad en grondige kennis van die musiek van die bruinmense van die Kaap. Dit het hom stilisties beïnvloed en hy het ook musiek spesifiek gemik op daardie klein mark, saam met Stan Murray se Penny Serenaders. Die feit dat wit musikante bruin musiek vir 'n bruin mark uitgereik het in die laat 1950's getuig natuurlik van die gebrek aan geleenthede vir bruinmense om musiek op te neem.

Maar terwyl hierdie suksesverhale 'n vlak van lewenskragtigheid in die Afrikaanse kultuurbedryf aandui, moet dit gesien word teen die agtergrond en uitwerking van die immer-groeiende web van apartheidwetgewing in daardie tyd. Die vernietiging van Sophiatown vanaf 1955 het 'n einde gebring aan 'n swart kulturele spilpunt van buitengewone belangrikheid en het so ook die moontlikheid van verdere kulturele uitruilings tussen musikante van verskillende rasagtergronde in die Johannesburg-gebied beperk. Kwêla was die musiek van weerstand, van 
die viering van swart wees, van die alledaagse lewe en die dansmusiek van die tyd. Dit was 'n kombinasie van Afrika-tradisie en ingevoerde musiekstyle wat nuwe stedelike, nie-tradisionele identiteite na vore gebring het wat in opposisie was met die apartheidregering se beleid om stam- en landelike identiteite te onderhou. Die gewildheid daarvan onder witmense het dit as iets anders herposisioneer - letterlik 'n afgewaterde weergawe van die oorspronklike - wat min te doene gehad het met die oorsprong daarvan. Hierdie wyer gewildheid vanaf die laat-1950's af, net toe die masjinerie van rasseskeiding 'n realiteit begin word het, wys dat die kulturele toeëiening van die musiek van die rasse-“ander" vir kommersiële doeleindes nie 'n probleem was vir platemaatskappye en wit musikante nie. Dit het ook geen werklike kritiek ontlok van die ras-sensitiewe kulturele organisasies of die SAUK nie - dieselfde mense wat nogal sterk menings gehad oor byvoorbeeld die invloed van jazz op plaaslike Afrikaanse musiek. Aan die ander kant van die musikale spektrum was Die Briels, wat sentimentele, wit werkersklas sangers was, wat ingekoop het in 'n ongesofistikeerde mark en op 'n manier iets anders as die Euro-kitsch-hoofstroom verteenwoordigheid het, wat vir hulle nogal steun gewen het onder die latere alternatiewe Afrikaners.

Terwyl Nico Carstens munt geslaan het uit die opbloei van die Afrikaanse musiekmark het Elvis Presley en rock 'n roll Suid-Afrika getref net so hard soos wat dit res van die wêreld geslaan het. Rock-musiek het sy oorsprong onder swart musikante in Amerika gehad, maar het meer gewildheid onder 'n wyer gehoor behaal toe dit deur wit musikante oorgeneem is. Op hierdie front het kwêla en rock 'n paar dinge in gemeen, soos wat Lara Allen korrek uitgewys het. Maar waar rock-musiek gedien het as 'n manier om rassekeidings in Amerika te oorbrug in 'n tydperk toe rassepolitiek 'n nuwe fase bereik het met die afskaffing van segregerende wetgewing en die opkoms van die burgerregtebeweging, het dit nie in Suid-Afrika dieselfde reggekry nie. Daar was baie kritiek teen die "euwels" van rock-musiek in Amerika en dit het uit talle oorde gekom, waaronder godsdiensleiers en konserwatiewes wie ongemaklik was met die ondermyning van die rashiërargie daarvan. In Suid-Afrika was dominees en die Afrikaner intelligentsia bekommerd, maar hul vrese was meesal ongegrond. Die rockers wat die lang pad na Suid-Afrika aangedurf het (meesal van Brittanje) was van die matigste, en minste kontroversieël van die lot. Polisiebeamptes wat onluste verwag het by konserte het uiteindelik verveeld geraak. Geen tiener het van die duiwel besete geraak soos wat sommige kerkleiers gevrees het nie. Die Nasionale Party het, in 'n opportunistiese skuif, selfs die bedreiging van rock vir politieke gewin teen die Verenigde Party in sy verkiesingsverldtog gebruik. Waarskynlik die belangrikste punt om te maak oor die ontvangs van rock-musiek onder die wit Suid-Afrikaanse jeug is dat die gewildheid daarvan, anders as in die res van die Westerse wêreld waar dit gewild was onder die jeug en waar musikante regstreeks verbind kon word met die geweldige sosiale veranderinge in die 1960's, geen so 'n invloed gehad het nie. Plaaslike musikante is natuurlik stilisties deur die nuwe klanke beïnvloed, en talle nuwe rock-groepe is gestig, waarvan die Vikings (wat in Engels gesing het) van die eerstes was. Maar daar is werklik min bewyse dat die Afrikaner-jeug van die 1950's, '60's en vroeë '70's enige soortgelyke linkse politieke agendas gehad het. Dit is belangrik om te vra hoekom dit die geval was. Die gebrekkige toegang tot linkse politieke literatuur, streng regeringsonderdrukking en die swakheid van die liberale linkses was belangrike faktore. Afrikaanse universiteite was ook broeikaste vir nasionalistiese ideologie en nie bekend vir hulle kritiek teen apartheid tot heelwat later nie. Baie Afrikaanse jongmense het rock-musiek aangegryp, maar dit het geen invloed op hulle politieke lewens gehad nie. 
Die gebrek aan uitgesprokenheid en die onkonfronterende houdings was alles aanduidings, en simptomaties, van die breër Afrikaner aanvaarding van apartheid in daardie tyd en het aangedui dat die Afrikaner tevrede was met die ekonomiese voordele en vir die oomblik van die gevolge daarvan kon vergeet.

Afrikaanse musiek tydens die hoogtepunt van apartheid was de-gepolitiseer tot nog lank ná die globale bewegings van die 1960's. Die kommersiële musiek van die tyd was meesal kitsch Euro-pop en geleende Schlager-musiek met Afrikaanse lirieke. Dit was baie ongewild onder die Afrikaanse jeug, wat as gevolg daarvan Afrikaans nie gesien het as cool genoeg en geskik vir die soort musiek waarna hulle geluister het nie. Maar, dungesaai tussen die country-tipe Afrikaanse melodieë en opera-tipe pop van sangers soos Gé Korsten was daar 'n paar subtiele teen-hegemoniese elemente. Dit was selde kommersieel suksesvol, maar sommige Afrikaanse kunstenaars het musiek uitgereik wat die idee van Afrikanerdom se hegemoniese karakter van daardie era ondermyn het. Mense soos Chris Smit, met die beeldmateriaal op sy plaat in 1962, of Coetzee en Ceronio met hulle weergawe van die verbande liedjie "Meadowlands" en liedjies met gemengde taal in die titels en vroeë Afrikaanse rock soos The Bravados in 1964 en The Hobos in 1966, het almal elemente getoon van 'n teenkultuur wat in teenstelling gestaan het met die hoofstroom Afrikaanse musiek. Dit was ook 'n tyd van toenemende sensuurskap en die SAUK se skynbaar wispelturige metodes om te bepaal wat kan uitgesaai word en wat nie. Maar om hierdie houding van gelatenheid van Afrikaanse kunstenaars te blameer op die streng sensuur van die SAUK en ander kulturele hekwagters soos die FAK, verklaar die bestaan daarvan slegs gedeeltelik. Suid-Afrika het, ten spyte van die hoë mate van sensuur en politieke beperkings, tesame met die laat koms van die televisie, dalk geïsoleerd voorgekom, maar die isolasie het ook beperkings gehad. 'n Voorbeeld daarvan is dat hoewel die Beatles in 1966 van die lug verban is, 'n mens steeds hulle albums kon koop of hulle musiek opvang op die naburige LM Radio. Weereens het die toegeeflikheid teenoor apartheid en die hoë lewensstandaard van witmense hier betrekking. As jy in wit, middelklas Suid-Afrika gebly het, het dit beteken jy was op institusionele en geografiese vlak ver genoeg verwyderd van die Afrika-deel van die Suid-Afrikaanse samelewing sodat jy sonder om twee keer te dink jou gemaklike Europese lewensstyl kon geniet.

Dit is waarskynlik om daardie rede dat kommersiële Afrikaanse popmusiek salig naby die boesem van die staat gebly het en dit wys hoe Afrikanernasionalisme ferm gesetel was in die Afrikanerkultuurbedryf. Wanneer 'n mens oplaas praat van weerstandigheid in populêre Afrikaanse musiek voor die laat-1970's dan praat 'n mens eintlik van 'n subtiele, dikwels onbeplande, uitdrukking van identiteit wat meer persoonlik as polities is. Hierdie houding het kwaai deurgeloop onder liberale Afrikaners na die einde van die 1970's en die 1980's toe die mislukking van apartheid op alle vlakke - sosiaal, politiek, moreel en ekonomies - duidelik geword het.

Hierdie stadige ontrafeling van Afrikaner-eenheid het ook gelei tot die opkoms van meer duidelike teen-hegemoniese identiteite in Afrikaanse musiek. Dit bly moeilik om te bepaal wat die presiese aard was van die verhouding tussen Afrikaanse kunstenaars, platemaatskappye, die sensuurraad van die apartheidstyd en die publiek wat Afrikaanse musiek koop in 'n tyd toe die bedryf relatief klein was. Kunstenaars moes pragmaties wees as hulle wou oorleef, wat meesal politieke radikalisme afgestomp het. Musiek-en-Liriek, wat in 1979 begin het, was nie 
hoofsaaklik oor politiek nie. Dit het wel die eerste beweging weg van die skynbaar toegeeflike lekkerliedjie na die meer introspektiewe luisterliedjie beteken. Wat betref die moontlik onnodige vraag of Musiek-en-Liriek 'n geloofwaardige beweging was of nie, moet 'n mens dalk die verhouding daarvan tot met dit wat dit voorafgegaan het in ag neem. Anders as die literêre Tagtigers wat gebou het op temas wat reeds deur 'n vorige generasie van skrywers gevestig is en dit geradikaliseer het, het die kunstenaars van Musiek-en-Liriek 'n aantal nuwe elemente by populêre Afrikaanse musiek gevoeg. Daar was 'n bietjie rock, folk, baie poësie en oor die algemeen meer intellektuele diepte. Die kunstenaars van Musiek-en-Liriek het eksperimenteer met hierdie nuwe artistieke beginsels en het gedeeltelik daarin geslaag om nuwe gemeenskaplike rituele (soos byvoorbeeld die Musiek-en-Liriek-konserte) te skep wat 'n bron van vernuwing en verjonging was. Maar dit was nie noodwendig radikaal nie en was nie verenigd nie. Die kunstenaars wat deel was daarvan het ook nie gevoel hulle is deel van 'n "beweging" per se nie. Dit is ook moeilik om die sentrale boodskap of etos van Musiek-en-Liriek af te baken anders as dat dit meer intellektuele Afrikaanse musiek vervaardig het. Dit was nie so polities soos die bewegings van die jare sestig in die Weste nie, of so polities soos die latere Voëlvry nie, maar dit behoort nie afbreuk te doen aan die bydrae daarvan nie. Die musiek van veral liedjieskrywers soos Koos du Plessis word vandag steeds hoog aangeskryf. Die feit dat dit met nuwe ontwikkelings in ander artistieke media saamgeval het dui daarop dat dit deel was van 'n wyer verskuiwing in Afrikaanse kunste in die algemeen. Dit was nie so kommersieel soos die hoofstroom Afrikaanse popmusiek nie, maar dit het goeie blootstelling op TV gekry en positiewe reaksies van die Afrikaner gemeenskap gekry en sommige albums, soos Laurika Rauch se Debuut en Anton Goosen se Boy van die Suburbs het goed verkoop.

Goosen was waarskynlik die mees antagonistiese van al die kunstenaars wat direk met Musiek-en-Liriek geassosieer is, maar sy onenigheid was nie tipies nie. Sy subtiele kritiese liedjies soos "Mpanzaville" en "Atlantis", gesing deur Laurika Rauch op Debuut in 1979, was nie die volle reikwydte van sy ondermyning nie. Hy het met die sensuurraad en kulturele organisasies gebots, klipharde Afrikaanse rock-musiek gespeel en het later baie uitgesproke geraak teen die politieke inskiklikheid van die Afrikaans hoofstroom tydens die "musiekoorlog" van 1990. Hoewel Afrikaners na rock en ander tipe musiek van oorsee geluister het, het dit om een of ander rede nie lewensvatbaar gelyk om hierdie soort musiek in Afrikaans te sing tot die laat-1970's en vroeg in die '80's nie. Die rock-musiek van Goosen en die groep Wildebeest in 1980 en 1981 getuig hiervan. Afrikaans was die taal van konserwatiewe ouers, weermagsersante, kwaai dominees, politici en apartheid. Oor die volgende paar jare was daar 'n toename in politieke temas - in die teater, musiek, kabarette en literatuur - in 'n tyd van 'n noemenswaardige ingryping deur die staat. Nuwe tipes populêre Afrikaanse musiek het te voorskyn gekom wat nie verbind is aan of deur Musiek-en-Liriek beïnvloed is nie. Die Afrikaner werkersklas-karakter Bernoldus Niemand was ver verwyderd van die poëtiese en literêre musiek van byvoorbeeld Koos du Plessis, en hoewel sy musiek kommersieel misluk het, was dit 'n vroeë weergawe van wat later die radikale Voëlvry-toer van 1989 sou word.

Die onthou en herdenking vandag van die kulturele belangrikheid van 'n Afrikaanse rock 'n roll-toer wat in 1989 plaasgevind het is 'n ingewikkelde sielkundige proses. Die impak van Voëlvry is versterk deur die literatuur en die verbygaande tyd en dit het die bydrae van ander alternatiewe Afrikaanse kunstenaars van daardie tydperk in die skadu gestel. Dit is moontlik dat Voëlvry gedenk word om op te maak vir die tekort aan struggle-kapitaal in Afrikanerkultuur. Die 
hoofteiken vir die beweging was die konserwatiewe middelklas Afrikaner gemeenskap waarin hulle grootgeword het. Hulle was op verskeie maniere ware radikale, en hoewel hulle baie spesifiek kon wees in hul kulturele aanval - hulle het individue soos P.W. Botha en Afrikaner simbole soos die ossewa in hulle satire identifiseer - was hulle apaties daaroor om saam te werk met swart anti-apartheidsbewegings. Middelklas wit voorstedelikheid met al die banaliteit daarvan is simbolies afgebreek, maar daarin lê die beperkings van die beweging. Voëlvry het nie die opkomende werkersklas of 'n samehorige politieke groepering verteenwoordig nie. Hoewel dit politieke ondertone gehad het, was dit nie 'n politiese beweging per se nie en aansprake dat dit apartheid tot 'n val gebring het is erg oordrewe. 'n Meer akkurate opsomming, sonder om deterministies te probeer klink, sou wees om dit te beskou as 'n produk van die tyd waarin dit plaasgevind het. Die sosiale kohesie en hegemonie van die Afrikaner-samelewing het genoegsaam uitgerafel vir Voëlvry en ander alternatiewe Afrikaanse kunstenaars om 'n nuwe vlak van resonansie met die meerste jong Afrikaners te vind. Maar 'n groot meerderheid van Afrikaners het gevoel dat die samelewing 'n veel groter uitdaging gehad het, naamlik 'n onbekende toekoms onder 'n regerende swart meerderheid. Onder hierdie omstandighede moes wit middelklas voorstedelikheid bewaar, en nie ondermyn, word nie.

Gesien teen die breër historiese konteks was populêre Afrikaanse musiek gekenmerk deur 'n gebrek aan bewegings eerder as aan 'n oorvloed daarvan. Onder die enkele bewegings (baie wyd gedefninieer) wat daar was, het Voëlvry uitgestaan en het dit gelyk soos die bekende en baie invloedryke musiekbewegings wat in Amerika en Brittanje ontstaan het in die tweede helfte van die twintigste eeu; bewegings soos rock'n roll en tot'n mindere mate punk. Op'n manier het hulle elemente van dekades van ontwikkeling in hierdie genres in 'n baie kort tydjie opgeneem Dit is wel belangrik dat, ten spyte van die ooreenkomste in voorkoms, daar fundamentele verskille ook was. Hulle was goed gedefinieer in vergelyking met losser groeperings van Afrikanse musiek wat die beweging vooraf gegaan het, hulle was rebels, ondermynend, luidrugtig en antagonisties, en Voëlvry het die grootste deel van die moontlike gehoor wat ontvanklik sou wees vir so 'n beweging op daardie tydstip in Suid-Afrika bereik. Uiteindelik was Voëlvry 'n uitbreiding, en die mees gepubliseerde weergawe van, 'n ondergrondse alternatiewe Afrikaanse musiektoneel wat begin het met Bernoldus Niemand se eerste enkelsnit, "Hou my vas Korporaal”, in 1983.

As 'n mens nog 'n stappie terug neem om te kyk na die artistieke produksie van Afrikaanse kunstenaars in die laat 1970's tot laat 1980's in sy geheel wat literatuur, teater, kabarette en musiek insluit, versteenwoordig dit een van die meer vrugbare eras in die geskiedenis van Afrikaanse kultuur. In hierdie konteks gesien, was Voëlvry 'n fundamentele voorbeeld van Afrikaanse protesmusiek in die apartheidera. Daar was ander Afrikaanse groepe - waarvan sommige op die oorspronklike Voëlvry-kompilasie in 1988 verskyn het - wat altyd subversief was, maar nooit met die toer geassosieer is nie. Die Houtstok-konsert die jaar daarna het 'n verhoog - en 'n groot gehoor - gebied aan baie van die ander alternatiewe Afrikaanse kunstenaars en kan gesien word as die hoogtepunt van die spanning tussen die alternatiewe Afrikaanse beweging en die polities inskiklike Afrikaanse musiekhoofstroom.

In die twintigste eeu het Afrikaanse kultuur die politiek gedien deurdat sommige Afrikaanssprekendes hulleself wou definieer in terme van nasieskap. As gevolg daarvan is dit in die openbare sektor ingebed omdat die staat steun gebied het aan die Afrikaanse kunste en ander kulturele projekte. Hoewel die populêre Afrikaanse musiekbedryf histories in die hande van 
platemaatskappye in privaat besit was en by tye 'n moeilike verhouding met die apartheidstaat gehad het, is hulle steeds indirek bevoordeel deur die prominensie wat die staat aan Afrikaans gegee het. Met die val van apartheid het die Afrikaanse kultuurbedryf die staatsteun verloor wat dit vir so lank geniet het.

Dit was moontlik 'n bedekte seëning aangesien die gevolglike privatisering van die Afrikaanse kultuurbedryf baie suksesvol was. Afrikaanse kultuur in die algemeen het hoogs gekommoditeer geraak op baie vlakke en in baie velde, soos toegewyde TV-kanale, Afrikaanse flieks, letterkunde, die pers, aanlynplatforms wat spesifiek Afrikaanssprekendes bedien, Afrikaanse korporatiewe identiteit en nog vele meer. 'n Deel van hierdie sukses is die persepsie dat Afrikaans beskerm behoort te word teen die bedreiging van erosie in 'n gemeenskap met 'n pluralistiese kultuur. Talle Afrikaners koop in op hierdie vrees en het 'veilige' hawens gevind in hierdie sektore waar hulle die meerderheid kan bly danksy hulle materiële rykdom. Die toename in Afrikaanse kunstefeeste, wat geskep is in reaksie op die verlies aan status toe Afrikaans gegaan het van een van twee amptelike tale tot een van elf, en die verlies aan staatsondersteuning vir die Afrikaanse kunste het ook ruimtes geskep waar Afrikaanse kultuur in 'geleenthede' omskep kon word, om te leen by Hauptfleish. Hierdie ruimtes bly egter steeds problematies. Ten spyte van werklike pogings deur die organiseerders om die aanbod op feeste uit te brei en te ontwikkel buite net die wit sektor van Afrikaanssprekendes (soos die Suidoosterfees in Kaapstad) beperk die ekonomiese mag van hierdie sektor ook, tot 'n mate, hierdie pogings. Dit het 'n direkte uitwerking op populêre Afrikaanse musiek ook.

Vir die Afrikanse musiekbedryf het die val van apartheid 'n bloeitydperk ingelui soos wat Afrikaanse kunstenaars die winsgewende Afrikaanse kultuurbedryf post-apartheid betree het. Die aantal kusntenaars wat oor die honderdduisend per album verkoop is 'n duidelike bewys hiervan. Maar, die historiese geïsoleerdheid van die Afrikaanse musiekbedryf het tot so 'n mate vasgebyt dat die boonste trappie van die leer steeds bestaan uit 'n homogene groep Afrikaanse sangers. Sommige Afrikaanse sangers het wit Afrikaners in die rol van die slagoffer geplaas met hulle vrees dat die Afrikanerkultuur besig was om te verdwyn tussen al die baie stemme en met hulle uitsprake oor kwessies soos misdaad. Sulke narratiewe maak die bedryf nog meer geïsoleerd. Popkonserte word homogene ruimtes waar die Afrikaner kan gaan wegkruip. Dit is nie net Steve Hofmeyr se konserte wat so is nie, maar ook konserte waarvan die lys van kunstenaars bepaal word deur hulle gewildheid. So is Afrikaans is Groot 'n meesal wit geleentheid, asook die Ghoema-toekennings. Dit bly baie moeilik vir bruin en swart Afrikaanse kunstenaars om toegang tot die mark te kry. Diegene wat dit regkry moet dikwels hulle musiek verteerbaar vir wit smake makk eerder as om 'n egte bruin musiekkultuur uit te druk.

As 'n laaste gedagte, die pertinente temas wat hier uitgelig is, het te doen met die manier waarop mense aanklank gevind het by Afrikaanse musiek met die verloop van tyd. Net soos wat mense marabi of die vroegste boeremusiek geniet het omdat dit 'n tydelike ontsnapping van die harde alledaagse lewe beteken het, het ander hulself na Euro-kitsch Afrikaanse pop gewend omdat dit geresoneer het met hulle romantiese aspirasies van Europese lewenstyle. 'n Mens kan nie musieksmaak absoluut verklaar deur dinge soos klas, opvoeding, politieke ideologie, geloof en ander soortgelyke faktore nie, maar hulle speel 'n belangrike rol om die produksie - en eintlik die bestaan - van populêre musiek te verstaan. Die sukses van hoofstroom Afrikaanse musiek vandag is niks nuuts nie. Die trajek daarvan sedert die begin van die twintigste eeu loop parallel 
met fundamentele ontwikkelings in terme van taal en identiteitspolitiek. En dit werk steeds so. Die voortsetting van populêre musiek wat vir en deur hoofsaaklik wit Afrikaanssprekendes vervaardig word, van die era van die vroegste taalaktiviste met die eeuwending tot die werkersklas-vastrapboereorkeste van die 1930's en die kommersiële ligte Afrikaanse musiek het nog nooit opgehou nie. Selfs die politieke Afrikaanse musiek van die jare tagtig, van Musiek-en-Liriek tot Voëlvry met sy konneksies tot literêre en teatrale kritiek teen apartheid van ander Afrikaanse kunstenaars, het ook gebeur binne die grense van wit Afrikanerskap. Binne die post-apartheid konteks het Afrikaanse musiek meer uiteenlopend geraak, maar baie kunstenaars het meer selfvertroue gekry om hulle politieke sienings te projekteer dikwels vergesel met 'n sterk dosis Afrikaner nostalgie. 'n Goeie vraag is natuurlik of dit regverdig is, of selfs relevant, om politiek te lees in iets so doodgewoon soos om na jou gunsteling sanger wie toevallig wit en suksesvol is se konsert te gaan. Of om na "De la Rey" in die agtergrond te luister terwyl jy braai saam met vriende. Dit is beslis nie bewustelike politieke dade nie. En daar is geen maklike antwoord nie. 'n Mens wil ook nie die hele Afrikaanse musiekbedryf en die geskiedenis daarvan in terme van ras alleen definieer nie. Aan die ander kant sal die talle besprekings oor Afrikaanse taalpolitiek en die toekoms daarvan goed doen as dit hierdie kompleksiteite in ag neem. Die vraag moet gevra word wat dit beteken wanneer Afrikaners terugwyk na afgesondere ruimtes, hoe onderhoubaar hierdie geïsoleerdheid is, en uiteindelik hoe dit hul verhouding met die breër Suid-Afrikaanse gemeenskap raak. 


\section{Argiefversamelings}

Universiteit van Stellenbosch, J.S. Gericke Biblioteek, Dokumentasiesentrum (US Biblioteek):

J.J. Smith Versameling

Melt J. Brink Versameling

G.G. Cilliers Versameling

H.B. Thom Versameling

Universiteit van die Vrystaat, Institute for Contemporary History Archives (INCH):

FAK-versameling

Douglas Fuchs Versameling

SAUK Inligtingsbiblioteek:

SAUK Jaarverslae, 1967-1969.

\section{Aanlyn Argiewe}

Alan Kelly katalogus, Centre for the History and Analysis of Recorded Music, beskikbaar by http://charm.rhul.ac.uk/index.html [besoek Mei-Oktober 2014].

The Alan Kelly Matrix listings, beskikbaar by http://www.normanfield.com/kelly.htm [besoek Junie 2014].

The South African Audio Archive, beskikbaar by http://www.flatinternational.org/template_ volume.php?volume_id=280[ besoek Junie 2014].

The Truesound Online Discography Project, http://www.truesoundtransfers.de/disco.htm [besoek Julie 2014].

\section{Verslae en dokumente}

De Villiers, D. 1954. "Die Afrikaner se musiekprestasies gedurende die afgelope kwarteeu”, gelewer by die FAK Silwerjubileumkongres, Bloemfontein, 29 September-3 Oktober 1954.

Cilliers, G.G. 1946, gelewer by die FAK Volkskongres, Stellenbosch.

Hartman, A. 1962. Die betekenis van musiek in ons Volkslewe", gelewer by die 16de tweejaarlikse FAK Kongres, 11-13 Julie 1962.

Roos, G. 1952. Algemene verslag gelewer by die Vyfde Jaarlikse Konferensie van Internasionale Volksmusiek, 14-17 Julie I952, in Journalof the International Folk Music Council 5,1 (1953):9-35.

Roos, G. 1957. "Die uitsaaiwese in diens van ons samelewing”, gelewer by die FAK Volkskongres, Augustus 1957, Stellenbosch.

Van der Merwe, N.J. 1931. Verslag van die Uitvoerende Raad, gelewer by die FAK Kultuurkongres, 21-23 Desember 1931, Kaapstad.

\section{Onderhoude}

Botha, P. 2014. Onderhoud. 24 Februarie, Belville. Onderhoud per e-pos 5 Mei.

Goosen, Anton. 2013.Onderhoud. 29 April, Gansbaai.

Hofmeyr, Steve. 2013 en 2017. Onderhoud per e-pos. Augustus en Mei.

Louw, Tertius. 2013 en 2014. Onderhoud. 19 September, 25 Julie en

19 Desember, Stellenbosch.

Pretorius, Boet. 2013. Telefoniese onderhoud, 22 Julie. 
Rauch, Laurika. 2013. Telefoniese onderhoud, 25 Julie.

Viljoen, Ollie. 2013 en 2014. Onderhoud. 18 September, Gordonsbaai en

22 Maart, Franschhoek

\section{Persoonlike en/of epos kommunikasie}

Albertyn, Chris

Allingham, Rob

Auld, Robin

Binge, Herman

Gibbs, Gerhard

Herselman, Gary

Latilla, Marc

Louw, Tertius

Maas, Deon

Masuka, Dorothy

Moller, Willem

Pearlson, Peter

Joubert, Schalk

Rankin, Tim

Raubenheimer, Carl

Roggeband, Ilza

Schmidt, Charles

Uys, Dirk

Van Deventer, Monica

Van Tonder, Jannie Hanepoot

Vas, Marq

Zoid, Karen

\section{Konferensie dokumente}

"Radio apartheid": Investigating a history of compliance and resistance in Afrikaans popular music, 1957 - 1992, gelewer deur "This is The Modern World": For A Social History of Rock Music Conference, Universiteit van Charles-de-Gaulle Lille 3, Frankryk, 13-15 Junie 2013, en by die 24th Biennial Conference of the Southern African Historical Society, Universiteit van Botswana, Gaborone, 27-29 Junie 2013.

"Hold me tight, Corporal": Early Afrikaans rock as subversive political texts during the last decade of apartheid, eur die 4de Global Conference - Urban Pop Cultures, in Lisbon, Portugal, 10-12 Mei 2014.

"The new laager: White nostalgia and victimhood in 21st century Afrikaans pop music", gelewer deur die Southern African Historical Society Conference, 1-3 Julie 2015, STIAS, Stellenbosch.

"Who's the boss?": Aggressive racial politics in post-apartheid Afrikaans pop, gelewer by ECAS 6, Sorbonne, Parys, 8-10 Julie 2015.

"Boeremusiek, Briels and Bernoldus" Class in twentieth century popular Afrikaans music, gelewer by SASRIM 2015, Universiteit van Kaapstad, 16-18 Julie 2015.

"Far Out" - South African counterculture in the face of apartheid, gelewer deur die 4de Swiss Historical Congress, Universiteit van Lausanne, Switzerland, 10-12 Julie 2016.

\section{Koerante en tydskrifte}

Beeld

Business Times

De Goede Hoop 


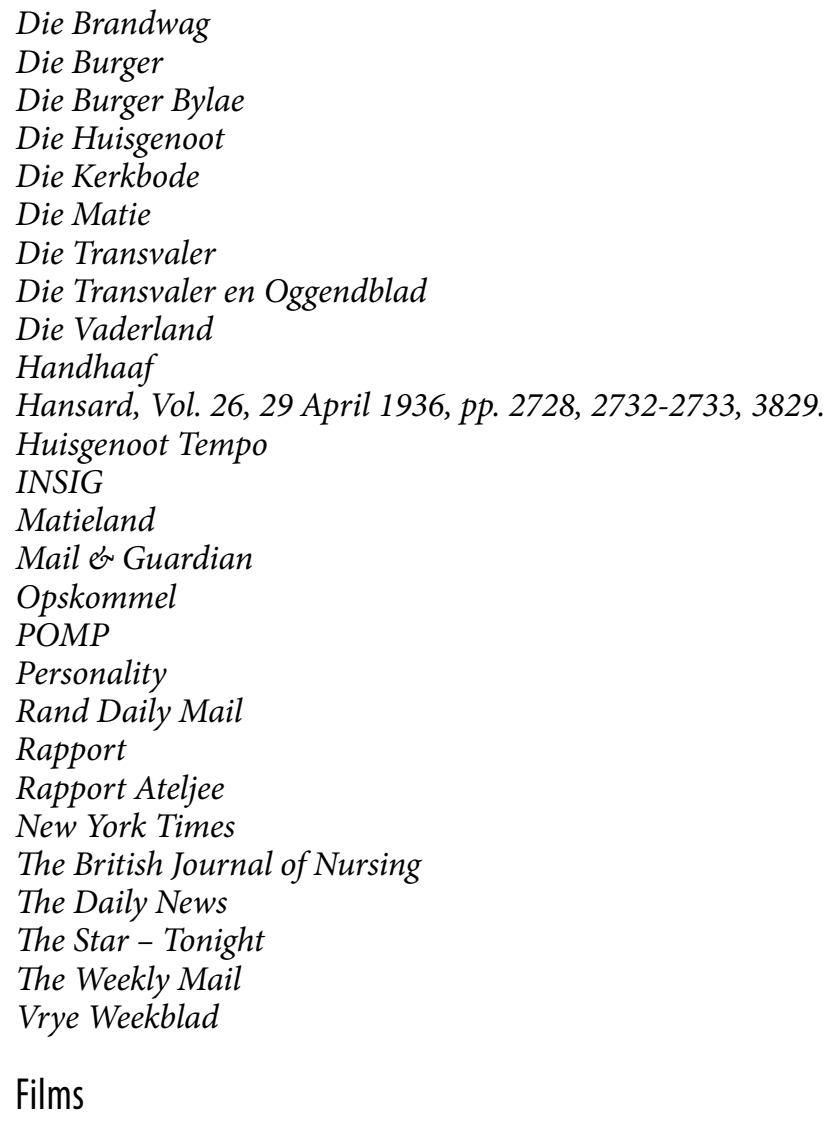

Punk in Africa (film). 2003. Peligroso Productions, Bohemian Lion, Meerkat Media. Searching for Sugar Man (film). 2012. Canfield Pictures, The Documentary Company. Voëlvry: The Movie (film). 2006. Shifty Studios.

\section{Dokumentêr}

Rauch, Laurika, Badenhorst, Johan en Bothma, Annelize. 2003. "Kom laat ons sing: 'n musikale reis deur Laurika Rauch - 'n Dokumentêr”. Laurika Rauch Produksies.

\section{Tweedehandse bronne}

Komposisies

Arnold Spoel, Vereenigd-Afrika. Lied en koraal voor eene zangstem en koor met piano- of orgelbegeleiding. Op. 18, ('s-Gravenhage: Van Eck, 1899).

\section{Boeke en hoofstukke in boeke}

Albertyn, J.R., The Poor White Problem in South Africa: Report of the Carnegie Commission, Deel V, (Stellenbosch: Pro Ecclesia, 1932).

Allen, L., 'Vocal Jive and Political Identity during the 1950's' in C. Lucia (red.), The World of South African Music: A Reader, (Newcastle-upon-Tyne: Cambridge Scholars, 2005).

Allen, L., "Kwela's White Audiences: The Politics of Pleasure and Identification in the Early Apartheid Period", in G. Olwage, (red.), Composing Apartheid: Music For and Against Apartheid, (Johannesburg: Wits Universiteit Press, 2008). 
Allingham, R., "South Africa - Popular Music: Nation of Voice," in S. Broughton, M. Ellingham \& R. Trillo (reds.), World Music: The Rough Guide. Africa, Europe and the Middle East, Vol.1, (Londen: Rough Guides, 1999).

Anderson, M., Music in the Mix: The Story of South African Popular Music, (Johannesburg: Ravan Press, 1981).

Baines, G. \& Vale, P. (reds.), Beyond the Border War: New Perspectives on South Africa's Late Cold War Conflicts, (Pretoria: Unisa Press, 2008).

Ballantine, C., Marabi Nights, Jazz, 'race' and society in early apartheid South Africa, (Scotsville: Universiteit van Kwa-Zulu-Natal Press, 3de Uitgawe, 2012).

Bauer, R., The New Catalogue of Historical Records, 1898-1908/09, (Londen: Sedgwick en Jackson, 1970).

Beinart, W., Twentieth Century South Africa, (Oxford: Oxford University Press, 2000).

Bester, P., Tradisionele Boeremusiek: 'n Gedenkalbum, (Pretoria: Sigma Press, 1987).

Blom, E. (red.), Grove's Dictionary of Music and Musicians, Vol. 11, (Londen: Macmillan \& Co. Ltd, 1954).

Bonner, P.; Delius, P. \& Posel, D. (reds.), Apartheid's Genesis, 1935-1962, (Johannesburg: Ravan Press, 1993).

Bouws, J., Solank daar Musiek is: Musiek en Musiekmakers in Suid-Afrika (1652-1982), (Kaapstad: Tafelberg, 1982).

Brackett, D., Interpreting Popular Music, (Cambridge: Cambridge University Press, 1995).

Brewer, J.D., "Memory, Truth and Victimhood in Post-trauma Societies", in G. Delanty \& K. Kumar (reds.), The Sage Handbook of Nations and Nationalism, (Londen:

Sage Publications, 2006). https://doi.org/10.4135/9781848608061.n19

Broughton, S.; Ellingham, M. \& Trillo, R. (eds.), World Music: The Rough Guide. Africa, Europe and the Middle East, South Africa - Popular Music: Nation of Voice, Vol. 1, (Londen: Rough Guides, 1999).

Burns, R. M. (red.), Historiography: Critical Concepts in Historical Studies Vol. IV, (Oxon: Routledge, 2006).

Cilliers, J., God for us? (Stellenbosch: AFRICAN SUN MeDIA, 2007).

Cope, J., The Adversary Within: Dissident Writers in Afrikaans, (Kaapstad: Philip, 1982).

Coplan, D., In Township Tonight!, (Johannesburg: Ravan Press, 1985).

Daniel, J. \& Vale, P., "South Africa: Where were we looking in 1968?", in P. Gassert \& M. Klimke (reds.), 1968 - Memories and Legacies of a Global Revolt, (Washington, DC: German Historical Institute, 2009).

Davies, R., Afrikaners in the New South Africa: Identity Politics in a Globalised Economy, (Londen: I.B. Tauris, 2009).

Deleuze G. \& Guattari, F., A Thousand Plateaus, (New York: Continuum, 2004).

Devroop, C. \& Walton, C. (reds.), Unsung: South African jazz musicians under Apartheid, (Stellenbosch: AFRICAN SUN MeDIA, 2007).

Drewett, M., "The Construction and Subversion of Gender Stereotypes in Popular Cultural Representations of the Border War", in G. Baines \& P. Vale (reds.), Beyond the Border War: New Perspectives on South Africa's Late Cold War Conflicts, (Pretoria: Unisa Press, 2008).

Drewett, M., "Packaging Desires: Album Covers and the Presentation of Apartheid", in G. Olwage (red.), Composing Apartheid: Music For and Against Apartheid, (Johannesburg: Wits University Press, 2008).

Du Buisson, M.S., Die Wonder van Afrikaans: Bydraes oor die ontstaan en groei van Afrikaans tot volwaardige Wêreldtaal, (Johannesburg: Voortrekkerpers, 1959).

Du Pisani, K., "Puritanism Transformed: Afrikaner Masculinities in the Apartheid and Post-Apartheid Period, in R. Morrell (red.), Changing Men in Southern Africa, (Durban: Zed Boeke, 2001).

Du Toit, A., Die Sondes van die Vaders (Kaapstad: Rubicon Press, 1983).

Erlman, V., African Stars: Studies in Black South African Performance, (Chicago: Universiteit van Chicago Press, 1991). 
Erlman, V., Nightsong: Performance, Power, and Practice in South Africa, (Chicago: Universiteit van Chicago Press, 1996).

Eyerman, R. \& Jamison, A., Music and Social Movements: Mobilizing Traditions in the Twentieth Century, (Cambridge: Cambridge University Press, 1998). https://doi.org/10.1017/CBO9780511628139

Federasie van Afrikaanse Kultuurvereniginge, FAK Silwerjubileum 1929-1954, (Johannesbrug: FAK, 1954).

Federasie van Afrikaanse Kultuurvereniginge, FAK-sangbundel: ' $n$ versameling van Afrikaanse musiek in ses verskillende rubrieke, Vol. II, (Pretoria: FAK, 2012).

Fiske, J., Television and culture, (Londen: Routledge, 1989).

Frith, S. (red.), Facing the Music, (New York: Pantheon, 1989).

Gaisberg, F.W., Music on Record, (Londen: Robert Hale, 1948).

Giliomee, H., Die Afrikaners:'n Biografie, (Kaapstad: Tafelberg, 2004).

Giliomee, H. \& Adam, H., Afrikaner Mag: Opkoms en Toekoms, (Stellenbosch: Stellenbosch Universiteit Uitgewery, 1981).

Goodwin, J. \& Schiff, B., Heart of Whiteness: Afrikaners Face Black Rule in the New South Africa, (New York: Scribner, 1995).

Grundlingh, A. \& Huigen, S., (reds.), Van Volksmoeder tot Fokofpolisiekar: Kritiese Opstelle oor Afrikaanse Herinneringsplekke (Stellenbosch: AFRICAN SUN MeDIA, 2008).

Gutsche, H., Erlank, W.J. du P. \& Eyssen, S.H. (reds.), Die F.A.K.-volksangbundel (Pretoria: De Bussy 1937).

Hall, S., "Cultural Identity and Diaspora", in J. Rutherford, (red.), Identity: Community, Culture, Difference, (Londen: Lawrence and Wishart, 1990).

Harrison, D., The White Tribe of Africa, South Africa in Perspective, (Berkeley: Universiteit van California Press, 1981).

Hartman, M., Anton Hartman: Dís Sy Storie, (Groenkloof: Mia Hartman, 2003).

Haupt, A., Stealing Empire: P2P, intellectual property and hip-hop subversion, (Kaapstad: HSRC Press, 2008).

Haupt, A., Static: Race and Representation in Post-Apartheid Music, Media and Film, (Kaapstad: HSRC Press, 2012).

Hayman, G \& Tomaselli, R., "Ideology and Technology in the Growth of South African Broadcasting, 1924-1971" in R. Tomaselli, K. Tomaselli \& J. Muller (reds.), Currents of Power: State Broadcasting in South Africa, (Kaapstad: Anthropos, 1989).

Hofmeyr, I., "Building a nation from words: Afrikaans language, literature and ethnic identity, 1902-1924", in S. Marks, \& S. Trapido (reds.), The politics of race, class and nationalism in twentieth-century South Africa, (Harlow: Longman, 1987).

Hofmeyr, S., Mense van my Asem (Kaapstad: Zebra Press, 2008).

Hopkins, P., Voëlvry: The Movement That Rocked South Africa (Kaapstad: Zebra Press, 2006).

Hutchinson, J. \& Smith, A.D. (reds.), Nationalism, (Oxford: Oxford University Press, 1994).

Jamieson, A. \& Eyerman, J., Music and Social Movements: Mobilizing Traditions in the Twentieth Century, (Cambridge: Cambridge University Press, 1998).

Klopper, A., "In wrede woede het ek die hand wat beheer gebyt': Die opkoms van Afrikaanse (punk) rockmusiek", in A.M. Grundlingh \& S. Huigen (reds.), Van Volksmoeder tot Fokofpolisiekar: Kritiese Opstelle oor Afrikaanse Herinneringsplekke, (Stellenbosch: AFRICAN SUN MeDIA, 2008).

Klopper, A., Biografie van 'n Bende: Die Storie van Fokofpolisiekar, (Kaapstad: Protea, 2011).

Kombuis, K.A., Seks, Drugs \& Boeremusiek: Die Memoires van 'n Volksverraaier, (Kaapstad: Human \& Rousseau, 2000).

Kombuis, K.A., Die tyd van die Kombi's, (Kaapstad: Human \& Rousseau, 2009).

Laubscher L., \& Nieman, G., The Carolin papers: a diary of the 1906/07 Springbok tour, (Pretoria: Rugbyana Publishers, 1990).

Lucia, C. (red.), The World of South African Music: A Reader, (Newcastle: Cambridge Scholars Press, 2005). 
Malan, J.P. (red.), Die Suid-Afrikaanse Musiek Ensiklopedie, Vol. 1, (Kaapstad: Oxford University Press, 1986).

Malan, J.P. (red.), Die Suid-Afrikaanse Musiek Ensiklopedie, Vol. 3, (Kaapstad: Oxford University Press, 1986).

Malan, J.P. (red.), Die Suid-Afrikaanse Musiek Ensiklopedie, Vol. 4, (Kaapstad: Oxford University Press, 1986).

Martin, D.C., "What's in the name 'Coloured'?", in A. Zegeye (red.), Social Identities in the New South Africa, (Kaapstad: Kwela, 2001), 249-268.

Martin, D.C., Sounding the Cape: Music, Identity and Politics in South Africa, (Somerset-Wes: African Minds, 2013).

Meintjies, L., Sound of Africa! Making Music Zulu in a South African Studio, (Londen: Duke University Press, 2003). https://doi.org/10.1215/9780822384632

Merrett, C., A Culture of Censorship: Secrecy and Intellectual Repression in South Africa, (Kaapstad: David Phillip Uitgewers, 1994).

Meyer, P., Nog Nie Ver Genoeg Nie: 'n Persoonlike Rekenskap van Vyftig Jaar Georganiseerde Afrikanerskap, (Johannesburg: Perskor, 1984).

Middleton, R., Studying Popular Music, (Milton Keynes: Open University Press, 1990).

Middleton, R. \& Horn, D. (reds.), Continuity and Change, (Cambridge: Universiteit van Campbridge Press).

Moodie, T.D., The Rise of Afrikanerdom: Power, Apartheid, and the Afrikaner Civil Religion, (Berkeley: Universiteit van California Press, 1975).

Nattiez, J., Music and Discourse: Toward a Semiology of Music, (Princeton: Princeton Universiteit Press, 1990).

Nixon, R., Homelands, Harlem and Hollywood: South African Culture and the World Beyond, (New York: Routledge, 1994).

Norval, A., Deconstructing Apartheid Discourse, (Londen: Verso, 1996).

Olwage, G. (red.), Composing Apartheid: Music for and Against Apartheid, (Johannesburg: Wits Universiteit Press, 2008).

O’Meara, D., Volkskapitalisme: Class, Capital and Ideology in the Development of Afrikaner Nationalism, 1934-1948, (Johannesburg: Ravan Press, 1983).

O'Meara, D., Forty Lost Years: The apartheid state and the politics of the National Party, 1948-1994, (Johannesburg: Ravan Press, 1996).

Orlik, P.B., "Radio in the Republic of South Africa", in S. Head (red.), Broadcasting in Africa: A Continental Survey of Radio and Television, (Philadelphia: Temple University Press, 1974).

Özkirimli, U., Theories of Nationalism: A Critical Introduction, (New York: Palgrave, 2000).

Pienaar, E.C., Die Triomf van Afrikaans: Historiese Oorsig van die Wording, Ontwikkeling, Skriftelike Gebruik en Geleidelike Erkenning van ons Taal, (Kaapstad: Nasionale Pers, 1943).

Ponelis, F., “The Development of Afrikaans”, in R. Dirven; M. Pütz \& S. Jäger (reds.), Duisberg Papers on Research in Language and Culture, Vol. 18, (Frankfurt: Peter Lang, 1993).

Pretorius, D.C., Musieksterre van gister en vandag: Lewensketse En Foto's Van Meer as 100 Musieksterre, (Pretoria: JP \& Son van der Walt, 1998).

Pretorius, F., Life on commando during the Anglo-Boer War 1899-1902, (Kaapstad: Human \& Rousseau, 1999).

Rachjman, J., The Deleuze Connections, (Cambridge, Mass.: MIT Press, 2001).

Roggeband, I., 50 Stemme: Die Grootste Name in Afrikaanse Musiek, (Kaapstad: Jonathan Ball, 2009).

Rojec, C., Pop Music, Pop Culture, (Cambridge: Polity, 2011).

Roos, G., Die uitsaaiwese in diens van ons samelewing, (Johannesburg: SAUK, 1957).

Roos, H., "Writing from Within: Representations of the Border War in South African Literature", in G. Baines \& P. Vale (reds.), Beyond the Border War: New Perspectives on South Africa's Late Cold War Conflicts, (Pretoria: Unisa Press, 2008). 
Rosenthal, E., Encyclopedia of Southern Africa 4th Edition, (Londen: Frederick Warne \& Co. 1967).

Rosenthal, E., You Have Been Listening: The Early History of Radio in South Africa, (Kaapstad: Purnell, 1974).

Roup, J., Boerejood, (Auckland Park: Jacana Media, 2004).

Sentrale Volksfeestekomitee., Gedenkboek: Voortrekker-Eeufees, 1838-1938, (Johannesburg: Sentrale Volksfeestekomitee, 1938).

Slabbert, M. \& de Villiers, D., David Kramer, 'n Biografie, (Kaapstad: Tafelberg, 2011).

Schultz, W., Die Ontstaan en Ontwikkeling van Boeremusiek, (Pretoria: A.V.A. Systems, 2001).

Steyn, M., Whiteness just isn't what it used to be: White identity in a changing South Africa, (Albany, NY: State University of New York Press, 2001).

Tomaselli, K. \& Tomaselli, R., "Between Policy and Practice in the SABC, 1970-1981", in R. Tomaselli, K. Tomaselli, \& J. Muller (reds.), Currents of Power: State Broadcasting in South Africa, (Kaapstad: Anthropos, 1989).

Tomaselli, R., Tomaselli, K. \& Muller, J., Currents of Power: State Broadcasting in South Africa, (Belville: Anthropos, 1989).

Trewhela, R., Song Safari, (Johannesburg: Limelight Press, 1980).

Uys, P., Between the Devil and the Deep: a memoir of acting and reacting, (Kaapstad: Zebra, 2005).

Van der Poel, J., Selections from the Smuts papers, Vol. V, (Cambridge: Universiteit van Cambridge Press, 1973).

Van der Poel, J., Selections from the Smuts papers, Vol. VII, (Cambridge: Universiteit van Cambridge Press, 1973).

Van der Westhuizen, C., White Power \& the Rise and Fall of the National Party, (Kaapstad: Zebra Press, 2007).

Van der Wouden. T. (red.), Roots of Afrikaans: Selected writings of Hans den Besten, (Amsterdam: John Benjamens, 2012).

Wasserman, H. \& Jacobs, S. (reds.), Shifting Selves: Post-Apartheid Essays on Mass Media, Culture and Identity, (Kaapstad: Kwela Books, 2003).

Wilkens, I. \& Strydom, H., The Super-Afrikaners: Inside the Afrikaner Broederbond, (Johannesburg: Jonathan Ball, 1978).

Witz, L., Apartheid's Festivals: Contesting South Africa's National Pasts, (Bloomington: Indiana Universiteit Press, 2003).

Zegeye, A. (red.), Social Identities in the New South Africa (Kaapstad: Kwela, 2001).

\section{Artikels en eweknie beoordeelde joernale}

Adhikari, M., “Not Black Enough': Changing Expressions of Coloured Identity in Post-Apartheid South Africa", South African Journal of History, 51, 1 (2004), pp. 167-178. https://doi.org/10.1080/02582470409464835

Baines, G., 'South Africa’s Vietnam'? Literary History and Cultural Memory of the Border War, South African Historical Journal, 49 (2003), pp. 172-192. https://doi.org/10.1080/02582470308671453

Ballantine, C., "Re-Thinking 'Whiteness'? Identity, Change and 'White' Popular Music in Post-Apartheid South Africa”, Popular Music, 23, 2 (2004), pp. 105-131. https://doi.org/10.1017/S0261143004000157

Blaser, T.M., "A New South African Imaginary: Nation Building and Afrikaners in Post-Apartheid South Africa", South African Journal of History, 51, 1 (2004), pp. 179-198. https://doi.org/10.1080/02582470409464836

Bosman, M., "Die FAK-Fenomeen: Populêre Afrikaanse Musiek en Volksliedjies", Tydskrif vir Letterkunde, 42, 2 (2004), pp. 21-46. https://doi.org/10.4314/tvl.v41i2.29672

Botha, E. \& Roodt, P.H., "Die Tagtigers en die Tydskrif vir Letterkunde - was daar 'n Tagtigerbeweging?", Tydskrif vir Letterkunde, 43, 1 (2006), pp. 57-67.

https://doi.org/10.4314/tvl.v43i1.29718 
Byerly, I.B., "Mirror, Mediator, and Prophet: The Music Indaba of Late-Apartheid South Africa", Ethnomusicology, 42, 1 (1998), pp. 1-44. https://doi.org/10.2307/852825

Callister, G., "Patriotic duty or resented imposition? Public reactions to military conscription in white South Africa, 1952-1972", South African Journal of Military Studies, 35, 1 (2007), pp. 46-67.

Colmeiro, J., "A Nation of Ghosts?: Haunting, Historical Memory and Forgetting in Post-Franco Spain", Electronic Journal of Theory of Literature and Comparative Literature (2011), pp. 17-34.

Coplan, D., "Sounds of the 'Third Way': Identity and the African Renaissance in Contemporary South African Popular Traditional Music", Black Music Research Journal, 21, 1 (2001), pp. 107-124. https://doi.org/10.2307/3181595

Delport, A., "Canto Ergo Sum: I Sing, Therefore I Am", Muziki, 3, 1 (2006), pp. 5-15. https://doi.org/10.1080/18125980608538779

Drewett, M., "Battling over Borders: Narratives of Resistance to the South African Border War Voiced through Popular Music", Social Dynamics: A journal of African studies, 29, 1 (2003), pp. 78-98. https://doi.org/10.1080/02533950308628651

Drewett, M., "Stop this filth': the censorship of Roger Lucey's music in apartheid South Africa”, SAMUS, 25 (2005), pp. 53-70.

Frith, S., "Rock and the Politics of Memory", Social Text, 9, 10 (1984), pp. 59-69. https://doi.org/10.2307/466535

Froneman, J.D., "H.F. Verwoerd's student years - cradle of his political career and thought", Koers, 65, 3, (2000), pp. 399-412.

Froneman, W., 'She Danced Alone: Jo Fourie, Songcatcher of the Groot Marico, Ethnomusicology Forum, 21, 1 (2012), pp. 53-76. https://doi.org/10.1080/17411912.2012.659447

Froneman, W., "Seks, Ras en Boeremusiek: agter die retoriek van gebrekkige sanglus by die 1938-Voortrekkereeufees", Litnet Akademies, 11, 2 (2014), pp. 422-449.

Goehr, L., "Political Music and the Politics of Music", The Journal of Aesthetics and Art Criticism, 52, 1 (1994), pp. 99-112. https://doi.org/10.2307/431589

Grové, I., “'Making the Dutchman proud of his language ...: 'n Honderd jaar van die Afrikaanse kunslied", Tydskrif vir Geesteswetenskappe, 51, 4 (2011), pp. 666-679.

Grundlingh, A., "Rocking the boat'? The 'Voëlvry' music movement in South Africa: Anatomy of Afrikaans anti-apartheid social protest in the eighties", International Journal of African Historical Studies, 37, 3 (2004), pp. 483-513. https://doi.org/10.2307/4129042

Grundlingh, A., "Die historiese in die hede: Dinamika van die De la Rey fenomeen in Afrikanerkringe, 2006-2007", New Contree, 53 (2007), pp. 147-166.

Grundlingh, A., “'Are We Afrikaners Getting too Rich?' Cornucopia and Change in Afrikanerdom in the 1960s", Journal of Historical Sociology, 21, 2/3 (2008), pp. 143-165. https://doi.org/10.1111/j.1467-6443.2008.00333.x

Grundlingh, A. \& Sapire, H., "From Feverish Festival to Repetitive Ritual? The Changing Fortunes of Great Trek Mythology in an Industrializing South Africa, 1938-1988”, South African Historical Journal, 21 (1989), pp. 19-37. https://doi.org/10.1080/02582478908671645

Hamm, C., "Rock 'n Roll in a Very Strange Society", Popular Music, 5, 1 (1985), pp. 159-174. https://doi.org/10.1017/S0261143000001975

Hamm, C., “'The Constant Companion of Man': Separate Development, Radio Bantu and Music", Popular Music, 10, 2 (1991), pp. 147-173. https://doi.org/10.1017S0261143000004487

Haupt, A., "Part IV: Is Die Antwoord Blackface?", Safundi, 13, 3-4 (2012), pp. 417-423. Haupt, A., "Citizenship without representation? Blackface, misogyny and parody in Die Antwoord, Lupé Fiasco and Angel Haze”, Communicatio, 39, 4 (2013), pp. 466-482. 
Hauptfleisch, T., "In Search of the Rainbow: The Little Karoo National Arts Festival and the Search for Cultural Identity in South Africa”, South African Theatre Journal, 15 (2001), pp. 79-96.

Hyslop, J., "Problems of Explanation in the Study of Afrikaner Nationalism: A Case Study of the West Rand", Journal of South African Studies, 22, 3 (1996), pp. 373-377. https://doi.org/10.1080/03057079608708500

Hyslop, J., "'Days of Miracle and Wonder'? Conformity and Revolt in Searching for Sugar Man”, Safundi, 14, 4 (2013), pp. 490-501. https://doi.org/10.1080/17533171.2013.841066

Johnson, J., review of Paddison, M., Analysis in Adorno's Aesthetics of Music, Music Analysis, 14, 2/3 (1995), pp. 295-313. https://doi.org/10.2307/854016

Jury, B., "Boys to Men: Afrikaans Alternative Popular Music, 1986-1990", African Languages and Cultures, 9, 2 (1996), pp. 99-109. https://doi.org/10.1080/09544169608717804

Kennelly, B., "Beauty in Bastardy? Breytenbach on Afrikaans and the Afrikaners", Portal Journal of Multidisciplinary International Studies, 2, 2 (2005), pp. 1-20. https://doi.org/10.5130/portal.v2i2.77

Kreuger, A., "Part II: Zefl Poor White Kitsch Chique: Die Antwoord's Comedy of Degradation", Safundi, 13, 3-4 (2012), pp. 399-408.

Lambrechts, L. \& Visagie, J., “De la Rey, De la Rey, Sal Jy die Boere Kom Lei?”, Litnet Akademies, 6, 2 (2009), pp. 75-105.

Laubscher, L., "Afrikaner Identity and the Music of Johannes Kerkorrel", South African Journal of Psychology, 35, 2 (2005), pp. 308-330. https://doi.org/10.1177/008124630503500209

Lüdemann, W., "Buren-Marsch: Die Transvaalse volkslied in Duitse gewaad", LitNet Akademies, 5,1 (2008), pp. 58-67.

Marx, H. \& Milton, V.C., "Bastardised whiteness: 'zef'-culture, Die Antwoord and the reconfiguration of contemporary Afrikaans identities”, Social Identities, 17, 60 (2011), pp. 723-745.

Mooney, K., "Ducktails, Flick-knives and Pugnacity: Subcultural and Hegemonic Masculinities in South Africa, 1948-1960", Journal of Southern African Studies, 24, 4 (1998), pp. 753-774. https://doi.org/10.1080/03057079808708600

Moore, A., Review, Music \& Letters, 77, 4 (1996), p. 658.

Mouton, A., "Reform from within': Schalk Pienaar, the Afrikaans press and apartheid", Historia, 45,1 (2000), pp. 149-176.

Muller, S., "Protesting Relevance: John Joubert and the Politics of Music and Resistance in South Africa", SAMUS, 19, 20 (1999/2000), pp. 33-46. https://doi.org/10.4314/samus.v19i1.6381

Nathaus, K., "From Dance Bands to Radio and Records: Pop Music Promotion in West Germany and the Decline of the Schlager Genre, 1945-1964", Popular Music History, 6, 3 (2011), pp. 287-306.

O'Toole, S., "Part I: Die Antwoord's state of exception", Safundi, 13, 3-4 (2012), pp. 393- 399.

Perry, J., "Nazifying Christmas: Political Culture and Popular Celebration in the Third Reich", Central European History, 38:4 (2005), pp. 572-605. https://doiorg/10.1163/156916105775563562

Pretorius, D., "The Visual Representations of Masculinities in Huisgenoot Tempo Magazine", Cmmunicatio, 39, 2 (2013), pp. 210-232. https://doi.org/10.1080/02500167.2013.788532

Rautenbach, S.C.H., "Die Kerksang as Agtergrond van die Poësie Uit die Eerste Tydperk", Tydskrif vir Volkskunde en Volkstaal, 3 (1946), pp. 85-87.

Roberge, P., "The Formation of Afrikaans", Stellenbosch Papers in Linguistics, 27 (1993), pp. 1-112.

Scott, C., "Die Antwoord and a delegitimised South African whiteness: a potential counternarrative?", Critical Arts, 26, 5 (2012), pp. 746-761.

Senekal, B.A. and Van den Berg, C., "'n Voorlopige Verkenning van Postapartheid Afrikaanse Protesmusiek", Litnet Akademies, 7, 2 (2010), pp. 98-128. 
Smit, S., "Enter the imperceptible: Reading Die Antwoord", Cogent Arts and Humanities, 2, 1 (2015), pp. 1-9.

Stell, G.; Luffin, X. \& Rakiep, M., "Religious and secular Cape Malay Afrikaans: Literary varieties used by Shaykh Hanif Edwards (1906-1958)", Bijdragen tot de Taal-, Land-en Volkenkunde, 163, 2/3 (2007), p. 289.

Steyn, J., "Die rol van die Afrikaanse pers in die taalstryd van die 1930's", Ecquid Novi: African Jounalism Studies, 7, 1 (1986), pp. 3-16.

Steyn, M., "Rehabilitating a Whiteness Disgraced: Afrikaner White Talk in Post-Apartheid South Africa", Communication Quarterly, 52, 2 (2004), p. 148.

Steyn, M., "The ignorance contract: recollections of apartheid childhoods and the construction of epistemologies of ignorance", Identities: Global Studies in Culture and Power, 19:1 (2012), pp. 8-25. https://doi.org/10.1080/1070289X.2012.672840

Tagg, P., "Analysing Popular Music: Theory, Method and Practice", Popular Music, 2 (1982), pp. 37-65. https://doi.org/10.1017/S0261143000001227

Titlestad, M., "The South African Life and Afterlife of Jim Reeves", The Journal of South African and American Studies, 15, 4 (2014), pp. 497-514. https://doi.org/10.1080/17533171.2014.941716

Van der Merwe, S.D., “'Radio Apartheid': Investigating a History of Compliance and Resistance in Popular Afrikaans Music, 1956-1979”, South African Historical Journal 66, 2 (2014), pp. 349-370.

Van der Merwe, S.D., "Kruger's lost voice: Nation and race in pre-World War I Afrikaans music records", Historia 6, 1 (2015), pp. 110-128.

Van der Waal, K. \& Robins, S., “De la Rey' and the Revival of 'Boer Heritage': Nostalgia in the Postapartheid Afrikaner Culture Industry", Journal of Southern African Studies, 37, 4 (2011), pp. 763-779. https://doi.org/10.1080/03057070.2011.617219

Van der Watt, L., "Part III: Ask no questions, hear no lies: Staying on Die Antwoord's surface", Safundi, 13, 3-4 (2012), pp. 409-416.

Van Wyk, J., "Afrikaans Language, Literature and Identity", Theoria: A Journal of Social and Political Theory, 77 (1991), p. 85.

Van Zyl, D., “'O, Boereplaas, Geboortegrond!' Afrikaner Nostalgia and the Romanticisation of the Platteland in Post-1994 South Africa", S.A. Tydskrif vir Kultuurgeskiedenis, 22, 2 (2008), pp. 126-148.

Vestergaard, M., "Who's Got the Map? The Negotiation of Afrikaner Identities in Post-Apartheid South Africa", Daedalus, 130, 1 (2001), pp. 19-44.

Viljoen, M., "Johannes Kerkorrel and post-apartheid Afrikaner identity", Literator, 26, 3 (2005), pp. 1-19. https://doi.org/10.4102/lit.v26i3.237

\section{Tesisse en proefskrifte}

Drewett, M., "An analysis of the censorship of popular music within the context of cultural struggle in South Africa during the 1980s", (DPhil Thesis, Rhodes Universiteit, 2004).

Froneman, W., "Pleasure Beyond the Call of Duty: Perspectives, Retrospectives and Speculations on Boeremusiek", (DPhil Tesis, Universiteit Stellenbosch, 2012).

Jansen van Rensburg, C., "Institutional Manifestations of Music Censorship and Surveillance in Apartheid South Africa with Specific Reference to the SABC from 1974 to 1996", (MMus Tesis, Universiteit Stellenbosch, 2013).

Kitshoff, H. v Z., "Die Opkoms, Dinamika en Betekenis van die Klein Karoo Nasionale Kunstefees 1995-2005”, (DPhil Tesis, Universiteit Stellenbosch, 2006).

Klopper, A.E., "Die Opkoms van Afrikaanse Rock en die Litirêre Status van Liriek, met Spesifieke Verwysing na Fokofpolisiekar", (MA Tesis, Universiteit Stellenbosch, 2009).

Louw, S.H.R., "Nico Carstens as innoveerder van Suid-Afrikaanse Populêre Musiek", (MMus Tesis, Universiteit van die Vrystaat, 2013).

Stimie, A., "Cosmopolitanism in Early Afrikaans Music Historiography, 1910-1948”, (MMus Tesis, Universiteit Stellenbosch, 2012). 
Swanepoel, A.M., "Music inspired by the Afrikaner cause (1852-1902), with special reference to the Transvaal Volkslied", (MA Tesis, Universiteit van Suid-Afrika, 1979).

Van den Berg, R.J., "Die Musiekaktiwiteite van die SAUK”, (MA Tesis, Noord-Wes Universiteit, 1976).

Van der Walt, P.J., "Die S.A.U.K., met spesiale verwysings na sy verhouding tot die staat", (MA Tesis, Noord-Wes Universiteit, 1973).

Van Heerden, E., "Liminality, Transformation and Communitas: Afrikaans Identities as Viewed Through the Lens of South African Arts Festivals 1995-2006”, (DPhil Tesis, Universiteit Stellenbosch, 2009).

Venter, C., "The Influence of Early Apartheid Intellectualisation on Twentieth-Century Afrikaans Music Historiography" (MMus Tesis, Universiteit Stellenbosch, 2009).

\section{Geouteurde internet artikels:}

Author unknown, Neerlandia 25. (Dordrecht: Geuze \& Co, 1921), beskikbaar by http://www.dbnl.org/tekst/_nee [besoek 16 Julie 2014].

Bezuidenhout, A., "Skielik is jy vry: Die lewe en musiek van Koos du Plessis", http://www.oulitnet.co.za/roof/roof16.asp [besoek 22 Januarie 2015].

De Vries, F., "Biografie van 'n bende: Fokof, we'll piss where we want", resensie op Litnet, 14 Junie 2011, http://www.argief.litnet.co.za/ [besoek 17 Julie 2013].

Gaisberg, F., “The Fred Gaisberg Diaries, Part 1: USA \& Europe”, http://www.recordingpioneers.com/docs/GAISBERG_DIARIES_1.pdf [besoek16 September 2016].

Haupt, A., "Is Afrikaans music the biggest 'rassedeurbraakmedium'?", beskikbaar by https://argief.litnet.co.za/article.php?news_id=6792 [besoek 17 Julie 2013].

Isaacs, L., "No more baas or Klaas at wine estate", 18 Januarie 2017, http://www.iol.co.za/ capetimes/news/no-more-baas-or-klaas-at-wine-estate-2097037 [besoek 4 April 2017].

Kelly, A., "Structure of the Gramophone Company and Its Output, HMV and Zonophone, 1898-1954", (2000), p. 3, beskikbaar by The Truesound Online Discography Project, http://www.truesoundtransfers.de/disco.htm [besoek 18 Julie 2014].

Kramer, D., http://www.oulitnet.co.za/mond/kkramer.asp [besoek 5 Junie 2013].

Lotter, C., "The De la Rey Phenomenon - More than a Song?", Voices: A World Forum for Music Therapy, 7:2 (2007), beskikbaar by https://voices.no/index.php/voices/article/ view/490/397 [besoek 10 April 2012].

Mooki, O., "Battle of the songs", 31 Januarie 2012, beskikbaar by http://www.iol.co.za/the-star/ [besoek 29 Mei 2012].

Opperman, D., "Revolution and conscience: South African theater, Junie 1976 tot Februarie 1990", Program of African Studies, Northwestern Universiteit, 5 1993, pp. 14-16, beskikbaar by http://quod.lib.umich.edu/p/passages/4761530.0005.012/ [besoek 2 Maart 2015].

Pakendorf, A., "Afrikaans music: History," beskikbaar by http://myfundi.co.za/e/Afrikaans_ music:_History" [besoek 28 Augustus 2011].

Roodt, D., “The 'De la Rey' Song. Is it a Sign of Afrikaner Resistance?”, American Renaissance, 18, 10 (2007), http://www.amren.com/news/2008/03/the_de_la_rey_s/ [besoek 10 April 2012].

Pogrund, B., “The 435 SA miners who didn't make it”, beskikbaar by http://www.timeslive. co.za/opinion/2010/10/14/the-435-sa-miners-who-didn-t-make-it [besoek 3 Junie 2013].

Roos, M., "Lewende legendes - Boet Pretorius", beskikbaar by http://152.111.1.88/argief/ berigte/beeld/1999/07/16/3/4.html [besoek 15 April 2013].

Terblanche, E., "Fanus Rautenbach, 1928-2011", beskikbaar by http://www.argief.litnet.co.za/ [besoek 14 April 2013].

Tolsi N. and Gedye, L., "White noise and lost irony" beskikbaar by http://www.theconmag. co.za/201/09/12/white-noise-and-lost-irony/ [besoek 15 September 2014]. 
Vorster, A., "Boet maak nou musiek op die Springbokvlakte!” beskikbaar by http://152.111.1.87/argief/berigte/rapport/2008/02/19/RG/4/Boet.html [besoek Zindi, F., "Dorothy Masuka: Age old inspiration", 11 Maart 2011, beskikbaar by http://www.herald.co.zw/dorothy-masuka-age-old-inspiration [besoek 20 Mei2015].

\section{Webtuistes en webbladsye}

http://afrmusieknuus.co.za/2016/10/19/afrikaans-groot-2016-nog-groter/

[besoek 14 Maart 2017].

http://ancestry24.com/history-of-music-in-south-africa/ [besoek 20 Junie 2012].

http://www.bdlive.co.za/national/2014/11/27/steve-hofmeyr-0-chester-missing-1

[besoek 26 Maart 2015].

http://beta.mnet.co.za/ChannelO/ChannelArticle.aspx?AId=15541 [besoek 20 Julie 2013]. http://www.bobdylan.com/de/node/26858 [besoek 20 Mei 2015].

http://www.boeremusiek.org/orkesteenkarakters.html\#DawidDeLange

[besoek 23 Augustus 2012].

http://www.channel24.co.za/Music/News/SAMA-audience-boos-Steve-Hofmeyr-20110523

[besoek 20 Julie 2013].

http://www.channel24.co.za/Music/FeaturesInterviews/2010-SAMA-Winners-20100414-2

[besoek 20 Juie 2013].

http://www.channel24.co.za/News/Local/Sunette-denies-racism-claims-20101029

[besoek 12 Augustus 2013].

http://www.channel24.co.za/Music/News/Hofmeyr-urges-fans-to-continue-singing-Die-

Stem-20140708 [besoek 25 Maart 2015].

https://www.channel24.co.za/music/news/land-rover-and-pick-n-pay-pull-concert-

sponsorship-after-steve-hofmeyrs-racist-tweet-20150317 [besoek 13 Maart 2017].

https://www.citypress.co.za/entertainment/dookoom-angry [besoek 26 Maart 2015].

https://entertainmentafrica.mobi/music/view/news/23934 [besoek 17 Julie 2013].

https://ewn.co.za/2015/04/08/Crowd-gathers-in-defence-of-the-church-square-statue

[besoek 20 Mei 2015].

https://www.facebook.com/groups/1409646456011242/?fref=ts [besoek 26 Maart 2015]. https://www.facebook.com/pages/Marq-Vass-Southern-African-Music-Collectibles

[besoek 15 April 2013].

https://www.facebook.com/search/top/?q=fokofcrowdfunding [besoek 22 Mei 2017]. https://www.facebook.com/shiftyseptember?ref=ts\&fref=ts [besoek September 2014]. http://www.freemuse.org [besoek 22 September 2010].

http://www.jitsvinger.co.za/ [besoek 17 April 2017].

http://www.juanitaduplessis.com/ [besoek 21 Julie 2013].

http://www.laurikarauch.com/biografie/2/ [besoek 09 Februarie 2015].

http://lmradio.org/History.htm [besoek 30 April 2013].

http://lowvelder.co.za/247693/hewige-reaksie-na-innibos-steve-nie-weer-nooi/ [besoek

30 Maart 2015].

http://mhambi.com/2010/02/ninja-is-the-new-james-phillips/ [besoek 13 August 2013]. http://myfundi.co.za/a/Radio-uitsendings_in_Suid-Afrika [besoek 20 Junie 2012].

http://www.netwerk24.com/nuus/2015-01-24-kknk-sou-steve-hofmeyr-nie-toelaat

[besoek 30 Maart 2015].

http://www.newsday.co.zw/2013/04/02/kknk-honours-dorothy-masuka/

[besoek 18 Julie 2013].

http://www.news24.com/Entertainment/SouthAfrica/Hofmeyr-Ill-do-it-again-20020401

[besoek 15 Julie 2013].

http://www.news24.com/Tags/People/sunette_bridges [besoek 12 Augustus 2013].

http://www.oulitnet.co.za/senet/senet.asp?id=48859 [besoek 23 Augustus 2012].

http://www.recording-history.org/HTML/impact_recorded_music12.php

[besoek 23 Augustus 2012]. 
http://rock.co.za/files/jp_niemand.html [besoek 21 Junie 2013].

http://www.rock.co.za/files/vinyl_sa_index2.htm [besoek 12 Augustus 2013].

http://www.roekeloos.co.za/ritme/die-saai-lewe.html [besoek 06 Maart 2015].

http://www.sabc.co.za/news/a/e8b1b3004f8495c9aeffee0b5d39e4bb/Dorothy-Masuka-

honoured-at-KANA-20130605 [besoek 18 Julie 2013].

http://www.sacp.org.za/docs/biography/2006/bramug.html [besoek 13 Maart 2013].

http://www.saiee.org.za/content.php?pageID=260\# [besoek 20 Junie 2012].

http://www.sahistory.org.za/dated-event/british-anti-apartheid-movement-hosts-concert-

mandela [besoek 20 Januarie 2014].

http://www.sahrc.org.za/home/index.php?ipkArticleID=330 [besoek 20 Mei 2015.]

http://saoperasingers.homestead.com/Kate_Opperman.html [besoek 28 November 2014].

http://soulsafari.wordpress.com/tag/music-and-censorship-during-apartheid-in-south-africa/

[besoek 22 Augustus 2013].

http://www.southafrica.info/about/arts/922563.htm\#ixzz21jQfFOKh [besoek 26 Junie 2012].

http://www.sowetanlive.co.za/entertainment/2015/04/20/xxi-south-african-music-awards-

samas---photos [besoek 28 Mei 2015].

http://springbokhits.blogspot.com/p/springbok-hit.html [besoek 24 Julie 2013].

http://www.springsteenlyrics.com/lyrics/f/froggiewentacourtin.php [besoek 20 Mei 2015].

http://stevehofmeyr.co.za/website/biography-parent?showall=1 [besoek 21 Julie 2013].

http://sunettebridges.co.za/ [besoek 16 Julie 2013].

http://www.thefreedictionary.com/ [besoek 30 April 2013].

http://www.3rdearmusic.com/lyrics/drywine.html [besoek 29 April 2013].

http://www.ticketpros.co.za/portal/web/index.php/event/14311756-bf77-294f-4cf6-

5836cf5e3e9e [besoek 14 Maart 2017.]

http://www.timeslive.co.za/politics/2014/10/15/afriforum-submits-hate-speech-complaint-

against-rap-group-dookoom [besoek 14 Januarie 2015].

http://www.timeslive.co.za/entertainment/2014/08/27/steve-hofmeyr-to-include-die-stem-on-

new-album [besoek 26 Maart 2015].

http://www.youares.com/v/fzYdYbHCOuU/die-antwoord-enter-the-ninja-live-rome/

[besoek 17 Julie 2013].

http://www.yourepeat.com/watch/?v=NAu6eR2KnNM [besoek 17 Julie 2013].

https://www.youtube.com/watch?v=14evw09Z3jY [besoek 12 Desember 2014].

https://www.youtube.com/watch?v=42wjiQmKC6Q\&hd=1 [besoek 24 Januarie 2014].

https://www.youtube.com/watch?v=K_XekcXPBQs [besoek September 2014].

http://www.youtube.com/watch?v=8r2uLdSlyg0 [besoek 10 Augustus 2012].

http://www.youtube.com/watch?v=qWONEFve-bY [besoek 10 Augustus 2012].

https://www.youtube.com/watch?v=kmgpDostEqk [besoek 26 Maart 2015].

https://www.youtube.com/watch?v=pRpeEdMmmQ0 [besoek 25 Maart 2015].

https://www.youtube.com/watch?v=F2wDNYVe7uo[besoek 30 Maart 2015].

http://www.youtube.com/watch?v=HsQf94hzExI [besoek 18 Julie 2013].

https://www.youtube.com/watch?v=gLPxMGxaosI [besoek 18 April 2017].

http://www.vetseun.co.za/anarkans/nav/toonsetverwerkkomposeer.htm,

[besoek 6 Augustus 2014].

http://www.wikiwand.com/af/Gawie_Cilli\%C3\%A9, [besoek 20 Maart 2017]. 


\section{A}

ABSA 152

Adams, Emo 142, 147, 152, 157

Aeolian Hall 31

Africana 21-22, 34, 136

Africana-grammofoonopnames 21, 23

Africana-liedere 23

African Broadcasting Corporation (ABC) 39, 44, $50,54,56$

African Jazz Pioneers 129

African National Congress (ANC) 83, 85, 125, $128-129,153-154$

Afriforum 142, 154

Afrikaans

alternatiewe $4,9,16,81,115,118,124-125$, $127-129,131-137,140,165,167-168$

eerste plate 38

feeste $3,59,135-136,140,144,149,150-152$, 156,169

gesange $25,29,34-35$

geskrewe taal 24-25

kortfilms 38

language 175

literêre bewegings 111

musiekbeweging 131, 135

musiekbewegings $7,16,116,127,130,168$

musiekgeskiedenis en erfenis $11,16,150$

musiekopnamebedryf $5,11,22,36-37,41,44$, 53,162

ondermynende rock 114

opgeneemde musiek 4-5, 11, 26, 161

pers $32,57,90,130-132,135,169$

plate $17,22,27,30,35,44,132,163$

popmusiek hoofstroom 4, 93, 132, 136-137, 142-143, 148, 156, 166-167

popsterre $3,9,152$

protesstemme 113, 130

psalms en gewyde liedere 25, 29, 35-36, 49

radio-uitsendings 56

rock $2,7-8,16,47,92,107,110,125,158$, 166-167

rock-liedjies 118

sprekers $1,4,11,56,70,122$

taal $19,26,29,161$

volksmusiek 72-73, 163

Afrikaanse Christelike Vrouevereniging (ACVV) 53

Afrikaanse Taal- en Kultuurvereniging (ATKV) 53, 58-59, 108, 132, 135, 147, 149

Afrikaanse Taalgenootskap 29

Afrikaanse Taalmonument 149
Afrikaans is Groot 141, 147, 156, 169

Afrikaaps 147

Afrikaner

jeug 125, 128, 131, 133

liberale 98

nasieskap 2, 36, 57, 67, 168

nasionale volksliedere $25,34-36$

nasionalisme E, 1, 4-5, 7, 11, 15-16, 23, 25, 31, $36,41,52-53,58-70,75,85,97,99,106$, $112-113,162-163,166$

nasionaliste $42,56-57,60$

sosialisme 58

Afrikanernasieskap 2, 24, 161

Afrikaners is plesierig 145

AHRC Research Centre for the History and Analysis of Recorded Music (CHARM) 22-23, 26

Ai meisie-meisie 94

aKing 144

Aldrin, Buzz 102

Allingham, Rob 4-5, 44-45, 47, 51, 70-71, 87

Amerikaanse musiek 4, 15

Amsterdamse Opera 23

Anglo-Boereoorlog 2, 20, 25, 28, 30, 32, 37

Antieke Griekeland 2

Apple iTunes 145

Armstrong, Neil 102

Atkins, Chet 91

Atlantis 107, 109, 167

Aucamp, Hennie 109, 113

AWB 155

\section{B}

Baboondogs 122

backtracks $3,16,136$

Baines, G 7, 114

Bala Broers 147

Ballantine, Christopher 45, 50-51, 76

ballingskap 24, 77, 127

banjo 44, 50

Baresel, Alfred 13

Bats, The 92, 110

Battery 9 104, 153

Beatles, 92, 95-97, 166

Bechstein Hall 33

Becker, Clarence Vivian 29

Beeskraal 153

Begrafnis in Zeerust 108

Beinart, William 113

Benade, Franna 134

Benade, Innes 134 
Berliner, Emile 20

Berlyn 1, 21, 23, 25

Bauer, Roberto 21

Bezuidenhout, Andries 7, 102-104, 111

Bezuidenhout, Evita 113

Bierman, Bennie 109

Bittereinder 144

Blackbyrd 147

Black Diamonds, The 34

blackface 6

Blignaut, Chris 9, 38, 41, 45-46, 49, 53, 60, 140,162

Bloedrivier 57

Blommetjie gedenk aan my 110

Bobbejaan klim die berg 155

Boegoeberg se dam 88

boer 2, 7-9, 20-21, 24-27, 29, 31-32, 34, 42, 50, 70, $88,132,143,149-150,154,176$

Pro-Boer sentimente 20

boeremusiek E, 5, 11, 14-15, 34, 38, 45-49, $51,-53,60,63,69-74,86,92,113,153$, 163-164, 169 vastrap $44,50,69,162,163$

boereorkeste 45-46, 50, 52, 69, 71, 117, 163

Boereseun 53

Boers, Je Vous Salue! 20

Boland Punk 3

Boone, Pat 90

Bosman, Danie 9, 53, 77

Bosman, Joey 32

Bosman, M 7

Bossies 115, 118

Botha, Corlea 147

Botha, Danie 134

Botha, Elize 111, 126

Botha, Louis 26

Botha, MC 60

Botha, Piet 117-118, 124

Botha, Pik 117

Botha, PW 105-107, 112, 114, 125, 168

Botteltjie Blou 109

Boude 109, 119

Bouwer, Stephan 102, 111

Brandewyn laat my staan 43, 73

Brasse Vannie Kaap (BVK) 146

Bravados, The 92, 110, 166

Brekfis met vier 111

Brel, Jacques 122

Breytenbach, Breyten 99

Bridges, Bles 9, 13, 106, 115, 131-134, 137, 139, 155

Onbekende Weermagman 115

Bridges, Sunette 155, 158

Bridging the Divide: The story of a Boer-British family 31

Briel, Anita 136

Briel, Frans 81, 136

Briel, Sannie 81, 136

Brigadiers 14, 85-86, 95, 102, 109, 134

Bright Blue 114

Brink, André P 112

Brink, Melt J 35

British Broadcasting Corporation (BBC) 54, 60, $67,74,84$

Britte 1-2, 21, 25, 34, 64, 163

Broederbond 54, 56, 59-60, 71, 109, 134

Brückner, Ewald 1-2, 23, 161

bruin

Afrikaanssprekendes 4, 11, 146, 149

arbeiders $73,155,163$

bendekultuur 6

erfenis 148

gehoor 104

gemeenskappe 149

identiteit 148

kultuur 108, 159, 169

kunstenaars 142, 146-148, 154

mense $10,35,78,146,148,164$

musiekmark 78-79, 164

musikante 3, 34, 80, 149, 163

tieners 90

toe-eiening 6

woonbuurte 104

Brunswick-Balke-Collender 41

Brussels 23, 24

Buren-Marsch 21, 25

Burger, Pieter 45

burgerregterlike-beweging 101

Burgers, Thomas 23

Bushrock band 124

Byerly, Ingrid 9, 12, 76, 85, 119

C

Callas, Maria 120

Calvert, Eddie 78

Cape and Peninsula Broadcasting Association 38

Carnegie Kommissie Ondersoek na die Armblankevraagstuk in Suid-Afrika 42

Carstens, Nico 5, 9, 50, 53, 72-73, 77-80, 89, 92-93, 96, 164-165, 173

Casspirs 124

Cele, Solomon "Zuluboy" 50-51, 76

Chaka Chaka, Yvonne 129

Chameleon, Chris 144

Cherry Faced Lurchers 114, 117

Christelik 10, 68, 151

Churchill, Winston 31

Cillié, G.G. 67-68, 94 
Cillié, Piet 84, 105

Clarke, W.H. 59

Clegg, Johnny 150

Coalbrook-mynramp 81

Coetzee en Ceronio 89, 166

Coetzer 44

Cogan, Alma 90

Coleske, Arnold 141

Coleske Artists 141

Columbia-platemaatskappy $35,41,43-45,50$, $78-79,96,162$

Carnival-reeks 78-79

Cooper, Cissie en Willie 9, 49, 53

Cornelli, H 1-2, 23, 161

Corporal Punishment 98, 117, 130

Country-musiek 4, 91

Cramer, Floyd 91

\section{D}

Damon, Adeimantus 2

Daniel, Raeford 106

Dans met die rooi rok 47

Darren, Kurt 8, 15, 140-141

Davidson, Lou 44

Day, Doris 48

Debbo, Al 9, 92

Debuut 104, 107, 137, 167

televisieprogram 137

Decibel-platemaatskappy 14, 119-120, 134-135

Degenaar, Johan 126

De Goede Hoop 30, 32

De Klerk, F.W. 125

De Lange, David 9, 46-49, 53, 56, 60, 117, 140, 162-163

De Lange, Silver 42

De la Rey 2, 4, 7-8, 142, 155, 157, 170

De la Rey, Koos 7

Dene, Terry 90

Den Haag 1, 23, 25

Denijs, Thomas 21-23

Departement van Binnelandse Sake 90

Dertigers 102, 111-112

De Villiers, Coenie 103, 120

De Villiers, Dawie 92

De Villiers, Dirkie 68, 94, 133

De Villiers, J.S. 25

De Vries, Abraham H 112

De Vries, Fred 150-151

De Vries, Mike 131

De Waal, Anton 9, 77, 91, 164

De Waal, Pieter 50

De Waal, Shaun 116

De Wet, C.R. 34, 36

De Wet Marsch 34
De Wet, Pierre 70

De Wet, Reza 112

Die Aap se Bruilof 43

Die Afrikaanse Patriot 24-25

Die Antwoord 6, 141, 151-152

Die Beeld 130-132, 152

Die Boeliebiefblik 74

Die Brandwag 25, 27-29, 32, 34-35

Die Briels 9, 81, 85, 93, 136, 165

Die Burger 26, 30-31, 57, 59-60, 64, 81, 84, 90-91, $95,97-98,111,131,135-36,150-151$

Die Donkie 49, 74

Die Eike 109

Die Ghitaar Pluk 89

Die hand vol vere 76

Die Heuwels Fantasties 141, 144

Die Huisgenoot 20, 25-26, 29-30, 32, 36, 93, 95-96, 121, 143

Skouspel 147

Tempo 7, 15-16, 143-144

Die Kêrels 127, 130

Die Kerkbode 95

Die Matie 131

Die Munisipale Militêre Orkes 23

Die myner's lied 81

Die Naglamp van Oom Piet 74

Die Naglopers 47, 69

Die padda wou gaan opsit 94

Die pas 121

Diepe Grond 112

Die Peerless Orkes 34

Die saai lewe 130

Die Ses Hartbrekers 42

Die somer is verby 103

Die sondes van die Vaders 105, 134

Die Stem 59, 147, 156-158

Die Suiderstem 57

Die Transvaler 49, 57, 103, 132

Die trein na Matjiesfontein 133

Die Vaderland 57, 103, 111

Die van Aardes van Grootoor 113

Die Vierkleur van die Transvaal 25

Die Vier Springbokke 42, 46

Die Vier Transvalers 42, 46

Die Volksblad 57

Die Volkstem 57

Die Vyf Dagbrekers 42, 46

Die Vyf Vastrappers 43, 69, 162

Die Wasgoedlyn 148 digitale musiek 140

Dillnutt, George Walter 20, 34, 35, 161

Di Ravelli, Bosman 31

Dis 'n Land 13-14

Distrik Ses 75, 107 
Distrik Ses - Die Musiekblyspel 122

DJ Ready D (Boeta D) 146

Dominion Party 55

Dookoom 155

Drewett, Michael 9, 96, 114-115, 118-119, 143

Dubhula I'bunu 154

Ducktails 87

Duits(e)

liturgiese en sekulêre liedjie 14

Schlager 11-14, 44, 85, 166

Duitsland 12, 37, 57, 63-64

Du Plessis, Jay 141, 147

Du Plessis, Juanita 8, 140-141, 147, 151

Jy voltooi my 140

Du Plessis, Koos 102-104, 131, 133, 167

Du Preez, Frik 92

Du Preez, Max 125, 133

Durban Corporation 38

Du Toit, André 97, 105, 134

Du Toit, André le Roux 111

Du Toit, D.F. 24

Du Toit, Jannie 103, 131

Du Toit, P.J. 35

Du Toit, S.J. 24, 25

$\mathrm{Du}$ Toit Smit, Louise 133

Dylan, Bob 2, 86, 94, 97

\section{E}

Edison Amberola Phonographs 20

Edison-Bell Company 36

Edison, Thomas 20

Eerste Taalbeweging 24-25

Eerste Wêreldoorlog 36-38, 162

Eeufeestrek 49, 51, 56-61, 63, 84, 162-163

Eitemal 43

Elias en sy Zigzag Jive Flutes 80

Elliot, Arthur 19

Elvis Blue 147

EMI 96

End Conscription Campaign (ECC) 114, 116-117

Engelbrecht, Theunis 130-132

Engels(e)

liturgiese en sekulêre liedere 12

gesange 12, 26, 29

Equity 90-91

Erasmus, Paul 115

Erfenisdag 153

Erlank, W.J. du P 43

Europeërs 2, 20, 43

setlaars 10

Eyerman, Ron 97, 110

Eyssen, Stephen 43-44, 65, 68
$\mathbf{F}$

Facebook 141, 155, 157-158

Faith, Adam 90-91

Fanagalo 89

fascisme 64

Federasie van Afrikaanse Kultuurvereniging (FAK) E, 7, 14-16, 25, 39, 43-44, 46-52, 54-60, 63-75, 81, 84, 88- 90, 93-95, 97, 108-111, 132-137, 141, 148, 162-164, 166

Kultuurkongres 43

lekkersingliedjies 60,94

Musiekkomitee 67, 71, 94, 163

Nasionale Jeugraad 93

Nasionale Kultuurraad 57, 64-65

Radiobond 64-66

Volksangbundel 44, 52, 57

Volkskongres 39, 54, 67

Ferguson, Jennifer 16, 127

Ferreira, Jurie 76, 95, 102

Fïesta-toekennings 128

FIFA Wêreldbeker-sokkertoernooi 152

Fischer, Bram 99

Flink uit die vere 80

Florean, Floriel 33

Fokofpolisiekar 7, 128, 138, 143-145, 150-151, 158

Hemel op die platteland 145

fonograaf $19-20$

Forces Favourites 117, 127

Forrest, Ada 33

Forrest, Billy 97

Fosatu Worker Choirs 127

Francis, Connie 90

Franse Hugenote 21

Free Mandela-konsert 127

Freemuse 119

Freshlyground 151-152

Froggy went 'a-courtin' 94

Froneman, Willemien 5, 11, 46, 49

Fuchs, Douglas 86-87

Fury, Billy 90

Fyn net van die Woord 102

G

Gabriel, Peter 127

Gaisberg, Fred 20

Gallo Record-platemaatskappy 4, 12, 35, 41, $44-45,47,49,74,88,107,137,164$

Gallotone-handelsmerk 41, 46, 79

Gatvol 119

Gedye, Lloyd 129

Geloftedag 59

Generaal de Wet 36

Genootskap vir Regte Afrikaners (GRA) 24 
Genuines, The 127

Gereformeerde Blues Band i, 126

Gesuiwerde Nasionale Party 15, 42, 55, 57, 63

gesuiwerdes 63

Ghitaar Boogie 89

Ghoema 77, 148-149

toekennings $148,159,169$

ghoemaliedjies 53

Gibson, Gilbert 91

Giliomee, Hermann 36, 43, 49, 58, 67, 83-84, $105-107,125,146$

God save the King 52

Goebels, Joseph 13

Goehr, Lydia 154

Goeiemôre Suid-Afrika 132

goema (sien ghoema) 78, 148

Goering, Herman 64

Gogga 92

Goosen, Anton 16, 47, 53, 64, 91, 103-104, 106-110, 118-122, 124, 129, 132-134 $136-137,139,148,153,167$

Boy van die Suburbs 167

Danzer 140

Gordimer, Nadine 99

GRA 24-25

grammofoon

opnames 2, 20-21, 23, 26, 38

plate $28,34,36,69$

Gramophone Concert-platemaatskappy 22 plate-reeks 27

Gramophone Record-platemaatskappy 20, 26, 28

Gramsci, Antonio 59

grensliteratuur 106, 118

Grensoorlog 105-106, 114-115

Grietjie 36

Groen en Goud 92

Groen is die land van Natal 94

Groen koringlande 94

Groepsgebiedewet van 195075

Groep Twee 9, 86, 94, 102-103

Groot Depressie 41-42, 50

Grové, Mynie 103

Grove's Dictionary of Music and Musicians 23

Grundlingh, Albert i, 7, 58, 83, 91, 128

Guthrie, Woody 94

Gutsche, Hugo 43

\section{H}

Haak Vrystaat 88

Haasbroek, PJ 112

Hall, Stuart 142

Hamba nontsokolo 76

Hamm, Charles 87

Handhaaf 43, 52, 90, 94, 97, 133
Happy Ships 121

Hark, Tom 80

Harris, Faan 42, 163

Hartman, Anton 48, 64-65, 69, 71-73, 168

Hasie 9, 92-93

Haupt, Adam 6, 149

Hauptfleisch, Temple 140, 152

Hayman, Graham 39, 54, 56, 61, 66, 75

Hecht, John 44

Hemelbesem 146-147

Herenigde Nasionale Party (HNP) 63

Herholdt, Sonja 110, 122, 126

Herselman, Gary 128-129

Hertzog, Albert 84, 101

Hertzog, J.B.M. 26, 31, 34, 36-37, 39, 42, 49, 54-57, 63, 101, 163

Het lied der Afrikaners 32

Het Moeder Kerk Koor 35

Het Volkslied van de Zuid-Afrikaanse Republiek 32

Heyns, JA 96

Hier kommie Bokke 140

Hillbrow 129, 153

hip-hop 3, 146-147, 155

Hitler, Adolf 57, 64

HMV Record-platemaatskappy 22, 27, 36, 44, 80

Hobos, The 92-93, 110, 166

Hofmeyr, Isabel 29

Hofmeyr, Steve 8, 137-138, 140-142, 144, 146-147, 153, 155-156, 158, 169

Ons sal dit oorleef 155,158

Pampoen 8, 142, 146

Toeka 8, 110, 140

Hollands(e)

kolonialiste 10

liturgiese en sekulêre liedjies 11

sangers 23

Schlager 12

taal 10

Holm, Erik 64

Holtzhausen, Nunez 44

Hommage aux Armeées Hérioiques des Republiques du Transvaal et d'Orange 20

homofobie 152

homoseksualiteit 143

Hoogenhout, CP 24

Hoor my lied 9, 85

Hopkins 132

Hopkins, Pat 5-6, 38, 98, 105, 111, 114, 116-117, $125-128,130-133$

Horings op die Stoep 115, 118

hotnotsmusiek $70,72,163$

Hou jou roksak toe 43

Hou my vas Korporaal 115-116, 118, 168

Houtstok 16, 121, 132, 134-137, 168 
Houtstok 2137

How much is that doggy in the window 136

H. Polliack \& Co. 35, 41

Hugo, Daniel 111

Hugo, Rina 131

humanisme 97

Hyslop, Jonathan 70, 98

\section{I}

Ian and Dix 96

identiteit

Afrikaner 7, 29, 57, 68, 75, 112, 125, 137, 143,153

bruin 148-149

etniese 113,162

Europese 11

kollektiewe 142

komplekse 89

korporatiewe 56, 169

kulturele 15, 61, 67

kultuur en rasgrense heen 145

linguistiese 10

manlike 114,118

nasionalistiese 69

politiese $33,36,89,125,155,162,170$

rasse $34,67,79$

rasse en kulturele 4,142

stereotipes $118,143-144$

Suid-Afrikaanse 56

teen-hegemoniese 166

Innibos 151-152, 156

In Tune with South Africa, Vol. 5: KWELA 80

isicathamiya 3

It's no secret (what God can do) 85

iTunes 145

\section{J}

Jacobie, Charles 85

Jaguar Land Rover Suid-Afrika 156

James, Lance 9, 102

Jamison, Andrew 97, 110

Jansen van Rensburg, C 118, 120, 122

Jantjie 110, 133

Javan, Les 148

Jay en Lianie 140

Bonnie en Clyde 140

jazz 3, 13, 50-51, 68-69, 71, 73, 76, 79, 152, 164-165

Jazz Maniacs 50-51, 76

Jennings, Edward 37

Jesus Christ Superstar 86

Jitsvinger 147

joernaliste $12,84,105,111,114,119,128,130$,
131,134

Johnny Kongos and The G-Men 92

Jolson, $\mathrm{Al} 44$

Jonker, Ingrid 112

Joos Tonteldoos en die Dwarstrekkers 130

Jordaan, Theuns 8, 104, 140, 142, 147

Roeper 140

Joubert, Elsa 112

Juluka (sien Johnny Clegg) 150

Jürgens, Udo 14

Jury, B 6, 9, 12, 76, 133, 140

K

Kaalvoet in die reën 133

Kaaprikaans 146

Kaapse Draai 53

Kaapse Klopse 13, 148

Karnival 13, 80

Kaapse Vlakte 120, 146

kabarette 115-116, 122, 167-168

Kadey, Ivan 127

Kalahari Surfers 114, 127

Kallitz 154

Kapel van het 7e Regiment Infanterie 23

Karoo Kitaar Blues 149

Katie 2

Keet, Rosa 104

Kelly, Alan 20, 22-23, 26-27, 29

Kelly, Les 45

Kennelly, Brian 146

Kennis van die aand 99

Kent gij dat Volk 23, 25, 31

Kerkorrel, Johannes 2, 7, 15, 104, 117, 124, 126-127, 129-131, 134-136, 153-154

Keuzenkamp, Carike 13-14, 110, 122, 131

Khoikhoi 10

Khoi-San 149

Kikini, Benjamin 123

Kimberley, Jim 91

Kinders van die wind 102, 103, 133

King Jr, Martin Luther 85

klas

konflikte $57-58$

middelklas $38,46,70,83,93,98,113,117,123$, $126,130,144,164,166,168$

onderskeid 46

ras $11,70,72,137$

spanning $93,162-163$

verskille $24,39,70$

werkersklas $6,24,46,49,51,57-58,64,69-70$, $74,81,93,116-117,130,136,151$, 162-163, 165, 167-168, 170

Klein Karoo Nasionale Kunstefees (KKNK) 128, $140,150,152,156$ 
Klein Maat 44

Klerewerkersunie 58

Klopper, Annie 7, 59, 150-151

Klopper, Henning 58

Koalisie 49

KOBUS 153

Koch, Konrad 156

koffiehuiskonserte 50

Kok, Benedictus 90

Kom kwêla vanaand met my 89

Kom laat ons sing 4, 5, 139

Kommissie van Ondersoek 102

kommunisme 97, 105

Kom saam vanaand 70

Kom vanaand in my Drome 69

konsertina 4-5, 44, 50, 92, 153

Konserwatiewe Party (KP) 97, 106, 117

Koos Kombuis 2, 5, 7, 47, 91, 104, 111, 113 $116-117,124-125,127,129,131,134-136$, 153-154

Bloedrivier 154

Langpad na Lekkersing 154

Korsten, Gé 9, 13-14, 85, 93, 95, 96, 102, 106, $114-115,131,135-136,166$

Huistoe 114-115

Sing Erika 95-96

Koue Oorlog 105

Koue vuur 104

Kraaines 117

Kramer, David 5, 7, 76, 103, 108-109, 111, 122, $126,129,131,134,149,154,158$

Kritzinger, Chris 110

Kruger, Paul 19, 24, 34, 158

Kruidjie roer my nie $107,109-110$

kultuur

Afrikaanse 4, 13, 38, 43-44, 47, 57, 60, 89-90, $105,110,112,132,134-135,140,142,145$, $150,152,162-163,167-169$

Amerikaanse 91, 101

bedryf 164, 169

bende 6

Europese 68

hip-hop 146

musiekkultuur 50, 128, 129, 148, 169

politieke 117

populêre $42,60,75,79,91,114-115,162-163$

teenkultuur 107, 166

volkskultuur 20, 70, 74

kultuurpolitiek 57, 60, 63, 162

kwaito 3

kwêla 3, 11, 53, 75-76, 78-79, 80-81, 88-89, 148,165

kykNET 144
L

Laager 103, 104, 113

Laarnie jou poes 155

Labour Party Club 46

Lakie, Frankie 92

Lamont, Collin 154

Lamprecht, Don 77

Lane, Frankie 48

Langa 123

Langenhoven, CJ 31

Lätti, Riku 148

Laubscher, Leswin 7

Leipoldt, C. Louis 26-27

lekkerliedjies 12, 85, 103, 132, 167

Lennon, John 96

Le Patriotisme des Boers 20

Leroux, Etienne 99

Le Roux, "Oom" Pietie 52

les lieux de mémoire 142

Lessing, Chris 45

Letoit, André 2, 111, 124, 126-127

liberalisme 97

Liefste Madeleine 94

Lighton, C. 19

ligte Afrikaanse musiek 13, 50-52, 69-70, 72-74, $94,132,163,170$

LAM 132, 134

Lindbergh, Des 103-104

Lisa se Klavier 129

Litnet 7, 46-47, 49, 151

Little Pal 44

Lloyd, Angela Read 31

LM Radio (Radio Lourenço Marques) 48, 80, 86, $89,91-93,166$

Londen 4, 11-12, 19-20, 23, 26-33, 35-37, 44-45, $51,59,142,145,161$

Palladium 33

Lopskop kwêla 88

Louw, Albie 80

Louw, Nicholis 15, 144

Louw, Tertius i, 75, 80, 86-87, 89, 91-92, 94

Lucey, Roger 114

Lucia Di Lammermoor 120

Lucky Dube 129

luisterliedjie 103, 106, 111, 167

Luyt, Flippie 50

Lynn, Vera 90

\section{M}

Maas, Deon 16, 130

Mackay Brothers-platemaatskappy 27, 34-35

Mahlasela, Vusi 127

Mahola, Zolani 152 
Makeba, Miriam 127, 150, 152

Malan, D.F. $15,42,49,57,59,81-82$

Malan, Jacques Philip 21, 27, 29, 31-36, 44, 66

Malan, Rian 47

Maleirslawe 10

Malema, Julius 154

Mamma ik wil een man hê 36

Mandela, Nelson 125

mandolien 44

manlikheid 143

marabi 3, 50-51, 53, 75, 79, 169

Marais, Joey 32

Marais, Kowie 65

Marche Hérioque des Boers 20

Marcuse, Herbert 97, 110

Marie, Cora 120

Markteater 103, 113

Martin, Denis-Constant 10-11, 15-16, 53, 76, 79, $146,148-149$

Marx, Frans 53

Masekela, Hugh 127

Mashiyane, Spokes 76

maskandi 3

Masuka, Dorothy 76-77, 82, 152-153

Max Normal TV 151

May, Lianie 140-141, 147, 154

Boeremeisie 140

mbaqanga $3,53,75$

mbube 3

Mbuli, Mzwakhe 127

Meadowlands 78, 89, 166

Mein Kampf 64

Meintjies, Les 3, 35, 37, 45

Menseregtekommissie 155

Met ander woorde 129

Meteors 88, 89

Met Permissie Gesê 113, 120, 126

Meyer 44, 66

Meyer, Piet 57, 66-67, 84, 102

MFP 96, 114, 135

militarisering 63, 114

Milner Park Rock-fees 97

Missing, Chester 156

Moeilike Mike 120

Möller, Willem 126, 128

Monare, Ignatius 44

Monumentkoppie 57, 59

Moolman, Jannie 147

Motsieloa, Griffiths 44

Mpanzaville 107-109, 167

Mr. Fat (Titus, Ashley) 146

msakazo 76

Muller, Johan 37

Murray, Stan 78-79, 164
Musiek-en-Liriek 5, 16-17, 103-104, 106, $107-114,116,120-122,125-126,131,133$, $166-167,170$

musiekoorloë 134

Musikale Mallemeule 102

Myburgh, Corrie 120

Myburgh, Wynand 150

My gryse ou moeder 81

$\mathbf{N}$

Nasionale Kunstefees 126, 130

Nasionale Liberalisme 84

Nasionale Party (NP) 15, 31, 42, 49, 51, 55, 57, 59, $63,66,68-69,71,75,77,83,88,90,93,99$, 100, 105-106, 113, 122, 125-126, 165

Nasionale Unie van Suid-Afrikaanse Studente(NUSAS) 87

NAT 46

Natal Mercury 30

Nathaus, Klaus 12

National Wake 127

Naudé, Churchill 148

Naudé, Tiny 92

Nazisme 64

Nederduits-Gereformeerde Kerk (NGK) 68, 75, 90, 93-96, 104, 106

Nel, Riana 140, 147

Die moeite werd 140

Die regte tyd 140

'n Engel in die hemel 81

New York Times 7, 8, 135

NG Kerk (sien Nederduits Gereformeerde Kerk) 150

'n Ieder Nasie 24-25

Niel, Herms 95

Niemand, Bernoldus 2, 115-118, 124, 127, 129, $130,167-168$

Swart Gevaar 124

Nixon, R. 101, 102

Nkosi Sikelel' iAfrika 123

noodtoestand 13, 106, 124-125, 134

Nora, Pierre 142

Nortje, Koos en Hester 81

nostalgie $16,36,51,136,142-144,148,157,170$

O

Odendaal, Tredoux 44

Oesfees 149

O'Meara, Dan 57-59, 63, 69-70, 112

Oos-Rand 46, 98, 116-117

Opperman, Deon 112

Opperman, Kate 32, 33

OppiAarde 151 
Oppikoppi 128, 140, 144, 151

Orange Grove 50

Oranje Vrystaat 2, 31, 32

Orlik, Peter 37, 65

Ossewabrandwag (OB) 63, 65-66

ossewaens 51, 57, 59, 77, 164

Oude Libertas-teater 103, 121

Oukraalliedjie 94

Ouma Briel. Sien ook Briel, Sannie

Ou Tannie Blues 135

Ou Tante Koos 36

\section{$\mathbf{P}$}

Pan Africanist Congress (PAC) 83, 85

Pannevis, Arnoldus 24

Parow, Jack 141, 144

Paswette 121

Pata Pata 76, 152

Paul Roos 26

payola 12

penniefluitjie $76,79-80,88$

Penniefluitjie-kwêla 80

Penny Serenaders 78-80, 164

Perspektief 102

Petersen, Taliep 122, 129

Petzer, Sam 45

Phillips, James 2, 115-118, 127, 130-131

Phoenix en Kie 103

Pick n Pay 156

Piekniek by Dingaan 124, 126-127, 129

piekniekliedjies 59

Pienaar, E.C. $10,60,67$

Pienaar, Schalk 84, 105

Pietman 121

Plato 2

platteland $3-4,39,42,46,49,51,55,57,61,63,66$, $93,104,108,126,145,147,149$

polisie

intelligensiediens 132

sekuriteits 82

veiligheids $105,114,136$

polkas 44

Port Elizabeth 37, 59, 158

Poskantoor 37

post-apartheid E, 5, 7, 96, 128-129, 137, 139-140, $145-146,149,152-153,157,162,169-170$

Potgieter, Gert 93

Pracher, Cecile 119, 121-122

Pratley, Colin 118

Preller, Gustav 29

Presley, Elvis 77, 89, 91, 94-95, 165

Pretorius, Boet 13, 75, 81, 88, 119, 141

Pretorius, Danie C 5, 7, 12, 14, 34, 41, 45-48, 50, $53,76-77,81,96,110,139,143-144$
Pretorius, Deidre 143

Pretorius, F. 34

propaganda 55, 64, 69, 115

Prophets of da City (POC) 146

Protea 7, 87, 88, 151

psigedeliese musiek 95

Publikasieraad 1974118

punk $7,16,98,116,127,129-130,151,168$

Q

Queen's Hall 33

$\mathbf{R}$

radio

Afrikaanse diens 49, 56, 65, 80, 163

"hams" 38

JB-diens 38, 50

radiostasie $38,74,148,164$

radio-uitsendings $37-38,56,86,163$

Radio 5103

Radio Bantu 54, 120

Radio Daventry 64

Radio Kalahari Orkes 47

Radio Rats 98

Radio RSA 85

Radio Zeesen 64

Raka 102

Rand Daily Mail 106

Randy Rambo en die Rough Riders 127, 130

Rapport 16, 47, 81, 103-104, 119, 135-136, 140-141

Raubenheimer, Carl 116

Rauch, Laurika 5, 102-105, 107, 111-112, 122, $129,147,152,167$

Rautenbach, Fanus 25, 80

Ravenscroft, Duffy 88

Reddingsdaadbond 52-53, 59, 67

Red October 155

Reeves, Jim 77-78, 91

Regal-handelsmerk 41-42

Reinecke, Sias 9, 94, 103

Reith, Sir John 54

Republiek van Zoid Afrika 145

Richard, Cliff 90

rieldans 149

rock 'n roll E, 83, 87-92, 97, 116, 125, 130, 165, 167,-168

Rock Party at the Pepsi Club with the Vikings 88

Rodriguez 98

Roggeband, Ilza 5, 8, 12-13, 15-16, 81, 85, $120-122,129,144,146$

Rolling Stones 95

Roodt, P.H. 111-112, 126 
Roos, Gideon 39, 50, 54, 66, 71, 74

Rosenthal, Eric 19, 37-38, 50, 54, 56

Ross, Lloyd 5, 121, 127, 134

Royal Academy of Music 30

Royal Albert Hall 31

\section{S}

Saans deur die tralies 81,85

Sankomota 127

Sanlam 56

Sapire, Hilary 58-59

Sarie Marais 9, 76

Sauer, Paul 55

Schlesinger Corporation 39

Schlesinger, Isidor 54, 56

Schoch Kommissie 66, 74

Schot, Betsy 21, 22

Schultz, Wilhelm 5

Schuster, Leon 8, 14, 120, 140

Schutte, Mike 120

Searching for Sugar Man 98

Seeger, Pete 94

Select-platemaatskappy 12,15

Senekal, B.A. en Van den Berg, C. 7, 153-154

sensuur $17,75,82,85-86,99,105,113,118-119$, $139,145,156,166$

sensuurraad 16, 106, 108, 110, 118-119, 137, $166-167$

Sestigers 99, 102, 111-112

Sex Pistols 116, 150

Shakira 152

Sharpeville-slagting $81,84-85$

Shaw, Min 9, 85, 93

Shifty Records 5, 117, 127-128

Shot down in the Streets 117

Silgee, Wilson 50-51, 76

Sililo, Edward 76

Singer-handelsmerk 35, 41, 46-47, 49

Skadu's teen die muur 103-104

Skielik is jy vry $102-103,111$

Skipskop 109

slagoffer 8,153, 155, 157, 169

smelters 63

Smit, Chris 87-88, 166

Smith, J.J. 26-27, 29-30, 161

Smuts, Jan 33, 42, 49, 55-57, 63-66, 91, 163

Snyders, Peter 111

Snyman, Gerrie 45-46

Snyman, Joe 43

Soek'n Ander 92

Sokrates 2, 21

Solidariteit 142

Solms-Delta 149

Sols, Loit 148
Something new from Africa 79

Sonder Jou 96

Songs of Courage 85

Sontonga, Enoch 123

Sophiatown 75, 78-79, 164

Soweto 3, 78, 107

Soweto-opstand 105

Spieksma, E 1-2, 23, 161

Spoel, Arnold 24

Springbok Hit Parade-albums 96-97

Springbok Nude Girls 3

Springbok Radio 74-75, 92, 94, 164

Springbokrugbyspan 11, 26-29, 34

Springfield, Dusty 90

Springs 90, 116-117, 127

Springsteen, Bruce 94

Sproeitjies 133

Sprokie vir'n stadskind 103

Stallard, C.F. 55, 56

Stamrood, Joey 32

Statebond 83

Statenbijbel 10

Steele, Tommy 90

Stegmann, F 30, 31

Stellenattle 3

Stellenbosch 3, 10, 26, 39, 42, 54, 67, 90, 93, $102-103,121,126,151,158,163$

musiektoneel 2

Universiteit i, 2, 5-7, 11, 26-27, 52, 96, 118, 122, $131,140,152$

Stellenbosch Boereorkes 52-53, 69

Ster van Bethlehem 120

Steyn, Anna 44

Steyn, Gerald 44

Steyn, Gerhard 144

Steyn, Marthinus 31

Stormjaers 65

Streeter, John Samuel 38

Strydom, Amanda 120-122, 126, 150, 152

sufrajette 33

Suid-Afrikaanse Biografiese Woordeboek 31

Suid-Afrikaanse Kommunistiese Party (SAKP) 99

Suid-Afrikaanse Menseregtekommissie 155

Suid-Afrikaanse Musiek Ensiklopedie (SAME) 21-23, 26, 29, 33-35

Suid-Afrikaanse Musiektoekennings (SAMA) 15, 129,140

Suid-Afrikaanse oudioargief 22

Suid-Afrikaanse Party (SAP) 42, 46, 49, 51

Suid-Afrikaanse Spoorweë 38, 58, 81, 162

Suid-Afrikaanse Televisie (SATV) 132, 134

Suid-Afrikaanse Uitsaaikorporasie E, 13-14, 17, 43, 47-52, 55-56, 60, 63-67, 71-75, 77, 80-81, 84-89, 93-96, 110, 116, 118-120, 
122, 132-135, 141, 163-166

Suid-Afrikaanse Weermag (SAW) 98, 105

Suidoosterfees 169

Suikerbossie 9, 47, 48, 162

Suriano, M. en Lewis, C. 7

Susan, Hendrik 9, 45, 49-52, 69-71, 73, 76-77, 163-164

Sussie se Samba 78

Swanepoel, AM 1,21, 23-25

Swart, C.R. 31

swart (mense)

Afrikaanssprekendes 4, 11, 149

arbeiders 81,89

bediendes 107

bendekultuur 6

bevolking 39

gehore 104,153

kulturele identiteit 75

misdaad 155

musikante $6,51,76-77,87,165$

politieke organisasies 83,125

radiostasies 76

samelewing 128

teater 113

weerstand 105, 138, 164

woonbuurte 50, 104

Swart, Valiant 3, 158

Swemmer, Arthur 48

\section{$\mathbf{T}$}

Tagtigers 111-112, 116, 126, 167

Tamatie vir die Partie 78

Tant Mossie se sakkie-sakkie boeredans 110

Taylor, Samuel Coleridge 31

Teirlynck, Jan 23

televisie $53,85,98,101-103,105,109,113,116$, $122,128,132,134-135,166$

Terreblanche, Eugene 155

The Peanut Butter Conspiracy 94

tiekiedraai 77

Toemaar die donker man 112

Toerien, Heine 14

Tolsi, Niren 129

Tomaselli, Keyan 37, 39, 54, 66, 84

Tomaselli, Ruth 37, 39, 54, 56, 61, 66, 75, 84

totale aanslag 106

totale strategie 106-107

Translvaalse nasionale volkslied 43, 52

Transvaal en Nederland 2, 23

Transvaalsch Volkslied 23, 25

Transvaalse Republiek 1, 34, 36

Transvaalse Staatsartillerie 37

Transvaalse Vrijheidslied 25

Treurnicht, Andries 106, 117
Trewhela, Ralph 20-21, 27, 29, 35, 38, 45-46, 49-51, 70, 74, 78

Triomf van die Afrikaanse Taal 67

Troubadour-platemaatskappy 78, 81-82, 91-93

Truesound Online Discography Project 21-22

Tsotsitaal 78, 80

Tweede Taalbeweging 27, 29

Tweede Wêreldoorlog 13, 44, 47, 49, 52, 61, 63

$\mathrm{U}$

$\mathrm{U}$ is ons Ster 85,86

Uit die jaar vroeg 71

Uitenhage 38,123

ukulele 44

Umshini wam 155

Unie van Suid-Afrika 29, 31, 55

Unie Volkslied 36

Universiteit van Pretoria 93, 97

Universiteit van Witwatersrand 86, 116

Urban Creep 127

Uys, "Dagga" Dirk 3

Uys, Pieter-Dirk 113

V

Vaderlands Liefde 36

Valentine, Dickie 90

Van Blerk, Bok 2, 6, 8, 140-142, 147

Afrikaner Hart 140

Van Coke, Francois 104, 128, 144, 146, 158

Van Coke, Kartel 104, 144, 158

Van den Berg, J.C. 2, 23, 153, 154

Van der Hoven, H.G. 95

Van der Merwe, Merwede 103

Van der Merwe, N.J. 148, 162

Van der Walt, P.J. 51, 71, 72, 76, 110

Van Dyl, Jan 45

Van Heerden, Etienne 111, 112, 152

Van Jaarsveld, Bobby 140-141, 147, 150-151

Wat geld nie kan koop nie 140

Van Jaarsveld, Karlien 141, 147, 151

Van Loggerenberg, Hansie 71

Van Niekerk, Clarabelle 103

Van Niekerk, Kosie 12, 15

Van Rees, Catharina 23-25

Van Rensburg, Louis 103

Van Rooyen, Anneli 14, 103

Van Staden, Hanneli 134

Van Tonder, Gert 94, 126, 129

Van Tonder, Jannie 126, 128

van Wyk Louw, NP 67, 83-84, 99, 102, 105, 128

Vat jou goed en trek Ferreira 34

Veertigers 111,112

Venter, Albie 95 
Venter, C. 6, 21

Vereenigd Afrika 24

Verenigde Party 57, 63, 90, 165

verkramptes 101

Versfeld, Willem 35

Verstraeten, Louis 24

Verwoerd, H.F. 26, 83-84, 101

Vierkleur 23, 25, 32

Vikings, The 88

Vilakazi, Strike 78-89

Viljoen, André 14

Viljoen, M. 7

Viljoen, Ollie i, 76, 87

viool 44, 50, 162

Visser, Annie 12, 26, 30-33, 161

Visser, Gert Petrus 30

Visser, Lily 31

Visser,Tom 31, 80

Vlaggelied 25

Voëlvry 2, 5-8, 13, 17, 38, 98, 111-114, 116-117, $122,124-138,144-145,151,153,159$, $167-168,170$

Volksangbundel 43-44, 52, 77, 163

volkseie vs. volksvreemde 15, 93, 135, 144, 162

volksfeeste 67

volksgeskiedenis 59

Volkslied van den Oranje Vrijstaat 23

Volksparty 63

volkspele 57, 59

Volksraad 30, 52, 55

Volstruisrivier 78

Voortrekker Dans 49

Voortrekker Danskwartet 43, 162

Voortrekkermonument 16, 53, 135

Voortrekker Nooi 49

Voortrekkers 59-60

kappies 59

rokke 59

Vorster, B.J. 65, 105

Vredelied over Transvaal 23

Vrye Weekblad 131-132, 135

Vryfees 153

Vrystaatse Republiek 2, 36

Vyfhoek Blues 89

\section{W}

Waar is jy? 92

Waffen-SS 95

Waka Waka 152

Walker, C. Denholm 35, 43

Walker, G.D. 38

walse 44

Wasserfall, Dewald 147

Waterblommetjies 109-110, 126, 133
Wat zien we in Transvaal 24

Webber, Andrew Lloyd 86

Weideman, George 112

Weltevrede 92

Weltevrede Stasie 92

Wêreldbeker-rugbytoernooi 8, 140

wêreldkampioene 140

Wêreldwye bewegings 97

Wes-Kaapse Provinsie 155

Wessels, Robbie 8

Wetenskaplike en Tegniese Klub 38

Wet no 22 van 193656

Wet op Amptelike Tale van die Unie 192539

Wet op Bevolkingsregistrasie van 1950146

Wet op die Bevordering van Gelykheid en die Voorkoming van Onbillike Diskriminasie 154

Wet op die Elektriese Telegraaf van 186137

Wet op Onderdrukking van Kommunisme van 195075

Wet op Publikasies van 197485

Wicomb, Randall 47, 126

Wie is Bernoldus Niemand? 116

Wildebeest 115-118, 167

Bushrock One 118

Wild Possums 2, 3

Willekens, Jan 23

Wingerdrock 3

Wise, Harold 38, 45

Wit Kaffers van Afrika 137

Wooldridge, Fred 80, 89

Woordeboek vir die Afrikaanse Taal (WAT) 26,148

Wright, Billy 45

Wysigingswet op Verdediging van 196798

\section{Z}

Zambezi 77, 78

Zoid, Karen i, 142-143, 145, 147, 152

Zonophone 22, 27, 35

Zuid-Afrikaansche Volsklied 24, 25

Zuid-Afrikaanse Republiek 32

Zuma, Jacob 155 